MARIA DO CARMO CUSTÓDIO DE SOUZA HUNOLD LARA

\title{
ARTRITE-ENCEFALITE DOS CAPRINOS - ASPECTOS CLÍNICOS E EPIDEMIOLÓGICOS
}

Tese apresentada para obtenção do título de Doutor junto à Faculdade de Medicina Veterinária e Zootecnia da Universidade de São Paulo.

\author{
Departamento: \\ Clínica Médica \\ Área de Concentração: \\ Clínica Veterinária \\ Orientador: \\ Prof. Dr. Eduardo Harry Birgel
}




\section{DADOS INTERNACIONAIS DE CATALOGAÇÃO-NA-PUBLICAÇÃo}

(Biblioteca da Faculdade de Medicina Veterinária e Zootecnia dạ Universidade de São Paulo)

Lara, Maria do Carmo Custódio de Souza Hunold Artrite-encefalite dos caprinos - aspectos clínicos e Lara. 247 f. : il.

Tese (doutorado em Clínica Veterinária) - Universidade de São Paulo. Faculdade de Medicina Veterinária e Zootecnia. Departamento de Clínica Médica, São Paulo, 2002.

Área de concentração: Clínica Veterinária.

Orientador: Prof. Dr. Eduardo Harry Birgel.

$\begin{array}{llr}\text { Unitermos: } & \text { 1.Transmissão. } & \text { 2.Lentivirus. } \\ & \text { 4.Artrite-encefalite dos caprinos. } & \text { 5.Caprinos. }\end{array}$ 
Ao meu amor, ARTHUR, por sua compreensão, amor e dedicação. 
Aos meus pais, CAROLINA e CASEMIRO, pelo carinho e amor que me dedicaram.

À minha irmã ANA e meu cunhado ELIEZER, exemplo de amor, cumplicidade e bondade, e aos meus sobrinhos CARÚ, FER e NETO, pelo carinho e compreensão que me dedicaram. 
Ao meu querido orientador, Prof. Dr. EDUARDO HARRY BIRGEL, pela orientação recebida durante todo o período de realização do doutorado, pelo incentivo, amizade, confiança, dedicação e por me guiar pelos caminhos da vida e da ciência. 


\section{AGRADECIMENTOS}

Ao Professor Titular do Departamento de Clínica Médica, bolsista nível 1-A do Programa de Produtividade Científica do CNPq e ex-bolsista da Fundação Alexander von Humboldt Prof. Dr. Eduardo Harry Birgel, pela carinhosa orientação durante o curso de pós-graduação, cuja participação foi de fundamental importância.

Ao Prof. Dr. Eduardo Harry Birgel Junior, pelas valiosas sugestões, participação direta na parte experimental deste trabalho e análise estatística dos constituintes bioquímicos.

À grande amiga Dra. Lilian Gregory, por me auxiliar nas colheitas e pelo seu apoio incondicional.

À colega Maria Aparecida Fernandes, querida amiga, que me auxiliou na colheita do material de pesquisa.

À colega Marta Lizandra do Rego Leal, pela grande ajuda na leitura das fitas de eletroforese.

À Adelaide Borges pelo auxílio no preparo da forma final de apresentação da tese.

À colega Liliane Tanus Benatti, pela amizade sincera e solidariedade. 
À querida Sra. Regina Mieko Sakata Mirandola pela amizade e auxilio nas provas laboratoriais.

À senhorita Clara Satsuki Mori pelo auxilio nas provas laboratoriais.

Ao colega Rinaldo Batista Viana, por me auxiliar na colheita do material e amizade.

Aos colegas do Curso de pós-graduação, Consuêlo, Valéria, Paula, Pierre, Macau, Paulo, Severino, Marcelo, Celso, Alice, Lúcia, João Paulo, Heloísa, Ricardo e Sandra pelo agradável convívio e amizade.

Aos funcionários do Departamento de Clínica Médica da Faculdade de Medicina Veterinária e Zootecnia da Universidade de São Paulo, em especial Danielle, Carmen, Dinha, Marli, Flor, Claudia, Elias, Edson, Luizinho e Miguel.

Às secretárias do Departamento de Clínica Médica Alice, Cida e Harumi por toda atenção e presteza.

Aos graduandos do curso de Medicina Veterinária, Simone, Camila, Ana Paula, Carlos Augusto, Leonardo, Carol, Chico, André e Adriana pela ajuda na manutenção dos animais recém nascidos e jovens no Hospital de Ruminantes da FMVZ-USP .

Aos colegas médicos veterinários Suely, Dri, Ricardo, Fernanda, Alessandra, Camila, Fabiana, Emy e Kátia, pelo auxílio na colheita do material.

Aos amigos do Laboratório de Raiva e Encefalites Virais do Centro de Sanidade Animal do Instituto Biológico, Elenice, Alessandra, Conceição, Márcia, Raquel e Rui por conviver com a minha ausência, pelo apoio e por compreender a importância do curso de pós-graduação.

À Dra. Margareth Élide Genovez, Diretora do Centro de Sanidade Animal do Instituto Biológico, pelo apoio logístico, facilitando a realização deste trabalho.

À Dra. Vera Cecília Annes, Diretora Geral do Instituto Biológico e à Dra. Teresa Jocys, que permitiram meu afastamento possibilitando desta forma o pleno desenvolvimento deste trabalho.

Aos professores do Departamento de Clínica Médica da Faculdade de Medicina Veterinária da Universidade de São Paulo, em especial o Prof. Dr. Fernando José Benesi, Prof. Dr. Wanderley Pereira de Araújo, Prof. Dr. Cássio Xavier Mendonça e Prof. Dr. Wilson Roberto Fernandes pelo convívio agradável, ensinamentos e amizade.

Aos meus amigos Marcelo, Anelisa, Alê, Thereza, Carla e Flávio. 
Aos criadores da Associação Paulista de Caprinos (CAPRIPAULO) que permitiram que suas propriedades fossem estudadas, em especial Sra. Marilena, Sr. Marco Antonio, Sr. Biscegli e Sr. Heider, que doaram animais para a realização de experimentos.

Aos funcionários da Biblioteca da Faculdade de Medicina Veterinária e Zootecnia da Universidade de São Paulo, pelo pronto atendimento na revisão das referências bibliográficas e na elaboração da ficha catalográfica.

Ao Centro de Pesquisa e Diagnóstico de Enfermidades de Ruminantes -CPDER- do Departamento de Clínica Médica da Faculdade de Medicina Veterinária e Zootecnia da Universidade de São Paulo, onde foram realizados os experimentos com os caprinos jovens.

A realização deste trabalho só foi possível graças ao apoio dos projetos FAPESP Infraestrutura e de auxílio à pesquisa recebidos anteriormente pelo meu orientador Prof. Dr. Eduardo Harry Birgel. 


\section{LISTA DE TABELAS}

TABELA 1 Valores do proteinograma ( $\mathrm{g} / \mathrm{dl})$ sérico de caprinos, descritos na literatura compilada, dando-se destaque aos autores e características dos animais. Valores apresentados em termos de média e desvio padrão $(\mathrm{X} \pm \mathrm{s})$.

TABELA 2 Caracterização do plantel de caprinos dos 14 Cabris utilizados para determinação da magnitude da prevalência da infecção pelo vírus da Artrite-encefalite dos Caprinos no Estado de São Paulo, no período de 2000-2001. São Paulo, 2002.

TABELA 3 Caracterização do plantel de caprinos dos 14 Cabris utilizados para determinação da taxa de incidência da infecção pelo vírus da Artrite-encefalite dos Caprinos no Estado de São Paulo, no período de 2000-2001. São Paulo, 2002.

TABELA 4 Caracterização dos grupos raciais utilizados para a avaliação da prevalência e incidência de anticorpos antivírus da Artriteencefalite dos Caprinos, no período de 2000-2001. São Paulo, 2002.

TABELA 5 Distribuição dos caprinos dos plantéis dos 14 Cabris, segundo o número de machos e fêmeas púberes. Destaque para os números de animais e de amostras colhidas no período de 2000-2001. São Paulo, 2002.

TABELA 6 Distribuição dos caprinos nos plantéis dos 14 Cabris, segundo o número de machos e fêmeas púberes e as raças dos animais. Destaque para os números de animais e de amostras colhidas no período de 2000-2001. São Paulo, 2002.

TABELA 7 Distribuição dos caprinos dos 14 Cabris. Estratificação segundo as faixas etárias. Destaque para o número médio de caprinos nos plantéis e número amostras colhidas no período de 2000-2001. São Paulo, 2002. 
TABELA 8 Distribuição dos caprinos dos 14 Cabris, segundo as características raciais e a faixa etária. Destaque para o número de animais e número amostras colhidas no período de 2000-2001. São Paulo, 2002.

TABELA 9 Distribuição dos caprinos dos 14 Cabris avaliados no Estado de São Paulo, estratificados segundo o sistema de criação (intensivo/semiextensivo), destacando-se os números de plantéis, média de animais e de amostras de soro sangüíneo colhidos. São Paulo, 2002.

TABELA 10 Resultados obtidos pela prova de imunodifusão em gel de ágar, para detecção de anticorpos anti-vírus da Artrite-encefalite dos Caprinos, em amostras de soro sangüíneo de animais criados no Estado de São Paulo, distribuídos segundo os rebanhos estudados e o número da colheita. São Paulo, 2002.

TABELA 11 Análise estatística das freqüências de anticorpos antivírus da Artrite-encefalite dos Caprinos em animais criados no Estado de São Paulo, distribuídos segundo a colheita realizada. São Paulo, 2002.

TABELA 12 Número e percentual de casos novos de Artrite-encefalite dos Caprinos, em animais criados no Estado de São Paulo. São Paulo, 2002.

TABELA 13 Análise estatística das taxas de incidência da Artrite-encefalite dos Caprinos em animais criados no Estado de São Paulo, distribuídos segundo a colheita realizada. São Paulo, 2002.

TABELA 14 Distribuição dos caprinos reagentes à prova da imunodifusão em gel de ágar para os antígenos da Artrite-encefalite dos Caprinos, agrupados segundo a raça e os momentos das colheitas. São Paulo, 2002.

TABELA 15 Distribuição dos caprinos reagentes e não reagentes à prova da imunodifusão em gel de ágar para os antígenos da Artriteencefalite dos Caprinos, agrupados segundo a raça. São Paulo, 
TABELA 16 Análise estatística das freqüências de anticorpos antivírus da Artrite-encefalite dos Caprinos em animais criados no Estado de São Paulo, distribuídos segundo a raça. São Paulo, 2002.

TABELA 17 Distribuição dos caprinos reagentes e não reagentes à prova da imunodifusão em gel de ágar para os antígenos da Artriteencefalite dos Caprinos, agrupados segundo o sexo. São Paulo, 2002.

TABELA 18 Análise estatística das freqüências de anticorpos antivírus da Artrite-encefalite dos Caprinos determinadas em animais criados no Estado de São Paulo, distribuídos segundo o sexo. São Paulo, 2002.

TABELA 19 Distribuição dos caprinos reagentes à prova da imunodifusão em gel de ágar para os antígenos da Artrite-encefalite dos Caprinos, segundo a faixa etária e omomento da colheita das amostras. São Paulo, 2002.

TABELA 20 Distribuição dos caprinos reagentes à prova da imunodifusão em gel de ágar para os antígenos da Artrite-encefalite dos Caprinos, segundo a faixa etária. São Paulo, 2002.

TABELA 21 Análise estatística das freqüências de anticorpos antivírus da Artrite-encefalite dos Caprinos determinados em animais criados no Estado de São Paulo, distribuídos segundo a faixa etária. São Paulo, 2002.

TABELA 22 Distribuição dos caprinos reagentes à prova da imunodifusão em gel de ágar para os antígenos da Artrite-encefalite dos Caprinos, agrupados segundo o sistema de criação e o momento da colheita das amostras. São Paulo, 2002.

TABELA 23 Distribuição dos caprinos reagentes e não reagentes à prova da imunodifusão em gel de ágar para os antígenos da Artriteencefalite dos Caprinos, agrupados segundo o sistema de criação. São Paulo, 2002. 
TABELA 24 Análise estatística das freqüências de anticorpos antivírus da Artrite-encefalite dos Caprinos determinadas em animais criados no Estado de São Paulo, distribuídos segundo o sistema de criação. São Paulo, 2002.

TABELA 25 Número de caprinos reagentes e não reagentes à prova da imunodifusão em gel de ágar para a Artrite-encefalite dos Caprinos, segundo a presença ou não de artrite. São Paulo, 2002.

TABELA 26 Análise estatística das freqüências de anticorpos antivírus da Artrite-encefalite dos Caprinos em animais criados no Estado de São Paulo. Distribuição segundo a presença ou não de artrite. São Paulo, 2002.

TABELA 27 Número de cabras reagentes e não reagentes à prova da imunodifusão em gel de ágar para a Artrite-encefalite dos Caprinos. Distribuição segundo a presença ou não de endurecimento da glândula mamária.

Resultados expressos em valores absolutos e relativos. São Paulo, 2002.

TABELA 28 Análise estatística das freqüências de anticorpos antivírus da Artrite-encefalite dos Caprinos determinadas em animais criados no Estado de São Paulo, distribuídos segundo a presença ou não de endurecimento da glândula mamária. São Paulo, 2002.

TABELA 29 Resultados da prova de imunodifusão em gel de ágar para detecção de anticorpos antivírus da Artrite-encefalite dos Caprinos submetidos a três tipos de aleitamento. Avaliação até 180 dias de vida. São Paulo, 2002.

TABELA 30 Resultados da prova de imunodifusão em gel de ágar para a detecção de anticorpos anti-vírus da Artrite-encefalite dos Caprinos, em animais com até 180 dias de vida, submetidos a três tipos de aleitamento. Valores referentes aaao $180^{\circ}$. dia de vida. São Paulo, 2002. 
TABELA 31 Resultados da prova de imunodifusão em gel de ágar para a detecção de anticorpos antivírus da Artrite-encefalite dos Caprinos, em cabritos neonatos, nascidos de partos eutócicos de cabras infectadas antes da ingestão do colostro. São Paulo

TABELA 32 Resultados da prova de imunodifusão em gel de ágar (IDGA) para a detecção de anticorpos antivírus da Artrite-encefalite dos Caprinos, em caprinos inoculados com colostro, leite e sangue infectados. Com ateristicos destacaram-se os resultados obtidos pelo teste ELISA. São Paulo, 2002.

TABELA 33 Valores médios (x) e desvios padrão (s) obtidos para os teores de proteína total sérica $(\mathrm{g} / \mathrm{dl})$ em cabritos crias de cabras soronegativas e soropositivas ao vírus da Artrite-encefalite dos Caprinos, agrupados de acordo com a idade, do nascimento antes da ingestão de colostro - até os 180 dias de vida. São Paulo, 2002.

TABELA 34 Valores médios (x) e desvios padrão (s) obtidos para os teores de gamaglobulina sérica $(\mathrm{g} / \mathrm{dl})$ em cabritos crias de cabras soronegativas e soropositivas ao vírus da Artrite-encefalite dos Caprinos, agrupados de acordo com a idade, do nascimento antes da ingestão de colostro - até os 180 dias de vida. São Paulo, 2002.

TABELA 35 Valores médios (x) e desvios padrão (s) obtidos para os teores de gamaglutamiltransferase sérica (UI/l) em cabritos filhos de mães soronegativas e soropositivas ao vírus da Artriteencefalite dos Caprinos, agrupados de acordo com a idade, do nascimento - antes da ingestão de colostro - até os 180 dias de vida. São Paulo, 2002. 


\section{LISTA DE FIGURAS}

FIGURA 1 Representação esquemática da distribuição dos soros e antígenos na realização da prova de imunodifusão em gel de ágar, para detecção de anticorpos antivírus da Artrite-encefalite dos Caprinos em amostras de soro sangüíneo

FIGURA 2 Disposição do antígeno (Ag), soro controle positivo $(+)$ e soros a serem examinados: S1 (positivo), S2 (positivo) e S3 (negativo) na prova de imunodifusão em gel de ágar, para detecção de anticorpos antivírus da q em amostras de s. Fonte: Veterinary Diagnostic Technology, In, Caev Immunodiffusion Reagents.

FIGURA 3 Distribuição percentual da freqüência da ocorrência de Artriteencefalite dos Caprinos, nos quatro momentos avaliados. São Paulo, 2002.

FIGURA 4 Freqüência da ocorrência de anticorpos da Artrite-encefalite dos Caprinos, determinada pela prova de imunodifusão em gel de ágar, em caprinos criados no Estado de São Paulo.

Distribuição segundo a raça. São Paulo, 2002.

FIGURA 5 Freqüência da ocorrência de anticorpos antivírus da Artriteencefalite dos Caprinos, determinada pela prova de imunodifusão em gel de ágar, em caprinos criados no Estado de São Paulo. Distribuição segundo o sexo dos animais. São Paulo, 2002.

FIGURA 6 Freqüência da ocorrência de anticorpos séricos antivírus da Artrite-encefalite dos Caprinos, determinada pela prova de imunodifusão em gel de ágar, em caprinos criados no Estado de São Paulo. Distribuição segundo a faixa etária. São Paulo, 2002. 
FIGURA 7 Freqüência da ocorrência de anticorpos antivírus da Artriteencefalite dos Caprinos, determinada pela prova de imunodifusão em gel de ágar, em caprinos criados no Estado de São Paulo. Distribuição segundo o sistema de criação. São Paulo, 2002.

FIGURA 8 Distribuição da freqüência de cabritos sororeagentes ou não ao vírus da Artrite-encefalite dos Caprinos, do GRUPO-A, em amostras de soro de cabritos que receberam colostro de cabras soropositivas e leite de cabras soronegativas. São Paulo, 2002.

FIGURA 9 Distribuição da freqüência de cabritos sororeagentes ou não ao vírus da Artrite-encefalite dos Caprinos, do GRUPO-B, em amostras de soro de cabritos que receberam colostro e leite de cabras soropositivas. São Paulo, 2002.

FIGURA 10 Distribuição da freqüência de cabritos, sororeagentes ou não ao vírus da Artrite-encefalite dos Caprinos, do GRUPO-C, em amostras de soro de cabritos que receberam colostro de cabras soronegativas e leite de cabras soropositivas. São Paulo, 2002.

FIGURA 11 Distribuição da freqüência de animais sororeagentes ou não ao vírus da Artrite-encefalite dos Caprinos, em amostras de soro de cabritos inoculados por tatuagens executadas com equipamento contaminado com sangue infectado pelo vírus da AEC. Determinação pela prova da imunodifusão em gel de ágar. São Paulo, 2002.

FIGURA 12 Distribuição da freqüência de animais sororeagentes ou não ao vírus da Artrite-encefalite dos Caprinos, em amostras de soro de cabritos inoculados por via intramuscular com leite oriundo de cabras sororeagente ao vírus da AEC. Determinação pela prova da imunodifusão em gel de ágar. São Paulo, 2002. 
FIGURA 13 Distribuição da freqüência de animais sororeagentes ou não ao vírus da Artrite-encefalite dos Caprinos, em amostras de soro de cabritos inoculados por via intramuscular com colostro oriundo de cabras sororeagente ao vírus da AEC.

Determinação pela prova da imunodifusão em gel de ágar. São Paulo, 2002.

FIGURA 14 Distribuição da freqüência de animais sororeagentes ou não ao vírus da Artrite-encefalite dos Caprinos, em amostras de soro de cabritos inoculados por tatuagens executadas com equipamento contaminado com sangue infectado pelo vírus da AEC. Determinação pelo teste ELISA. São Paulo, 2002.

FIGURA 15 Distribuição da freqüência de animais sororeagentes ou não ao vírus da Artrite-encefalite dos Caprinos, em amostras de soro de cabritos inoculados por via intramuscular com leite oriundo de cabras sororeagente ao vírus da AEC. Determinação pelo teste ELISA. São Paulo, 2002.

FIGURA 16 Distribuição da freqüência de animais sororeagentes ou não ao vírus da Artrite-encefalite dos Caprinos, em amostras de soro de cabritos inoculados por via intramuscular com colostro oriundo de cabras sororeagente ao vírus da AEC.

Determinação pelo teste ELISA. São Paulo, 2002.

FIGURA 17 Variação dos teores de proteína sérica total (g/dl), determinada no soro sangüíneo de cabritos crias de cabras soronegativas e soropositivas ao vírus da Artrite-encefalite dos Caprinos, do nascimento - antes da ingestão do colostro até 180 dias de vida. São Paulo, 2002.

FIGURA 18 Variação dos teores de gamaglobulina sérica $(\mathrm{g} / \mathrm{dl})$, determinada no soro sangüíneo de cabritos crias de cabras soronegativas e soropositivas ao vírus da Artrite-encefalite dos Caprinos, do nascimento - antes da ingestão do colostro até 180 dias de vida. São Paulo, 2002. 
FIGURA 19 Variação dos valores da atividade enzimática da gamaglutamiltransferase, expressos em UI/1, determinada no soro sangüíneo de cabritos crias de cabras soronegativas e soropositivas ao vírus da Artrite-encefalite dos Caprinos, do nascimento - antes da ingestão do colostro até 180 dias de vida. São Paulo, 2002 


\section{LISTA DE QUADROS}

QUADRO 1 Distribuição das taxas de prevalência da infecção pelo vírus da Artrite-encefalite dos Caprinos no Mundo, utilizando a prova de imunodifusão em gel de ágar, segundo o ano de avaliação, autor da pesquisa e o país de origem.

QUADRO 2 Distribuição das taxas de prevalência da infecção pelo vírus da Artrite-encefalite dos Caprinos no Mundo, utilizando o ensaio imunoenzimático (ELISA), segundo o ano de avaliação, autor da pesquisa e o país de origem.

QUADRO 3 Distribuição das taxas de prevalência da infecção pelo vírus da Artrite-encefalite dos Caprinos no Brasil, utilizando a prova de imunodifusão em gel de ágar, segundo o ano de avaliação, autor da pesquisa e o Estado da ocorrência.

QUADRO 4 Caracterização da população de caprinos utilizados para formação de grupos experimentais da presente pesquisa.

Distribuição segundo o número de amostras de soro sangüíneo colhidas nos quatro momentos, município de origem e o tipo de criação. São Paulo, 2002.

QUADRO 5 Caracterização do plantel de caprinos da raça Saanen do Cabril

1, destacando o efetivo existente e do qual foram colhidas quatro amostras de soro sangüíneo. Estratificação segundo a raça, o sexo e a faixa etária dos caprinos. São Paulo, 2002.

QUADRO 6 Caracterização do plantel de caprinos da raça Alpina do Cabril 2, destacando o efetivo existente e do qual foram colhidas quatro amostras de soro sangüíneo. Estratificação segundo a raça, o sexo e a faixa etária. São Paulo, 2002. 
QUADRO 7 Caracterização do plantel de caprinos da raça Saanen do Cabril

3 , destacando o efetivo existente e do qual foram colhidas quatro amostras de soro sangüíneo. Estratificação segundo a raça, o sexo e a faixa etária. São Paulo, 2002.

QUADRO 8 Caracterização do plantel de caprinos da raça Alpina do Cabril 3 , destacando o efetivo existente do qual foram colhidas quatro amostras de soro sangüíneo. Estratificação segundo a raça, o sexo e a faixa etária. São Paulo, 2002.

QUADRO 9 Caracterização do plantel de caprinos Mestiços do Cabril 3, destacando o efetivo existente do qual foram colhidas quatro amostras de soro sangüíneo. Estratificação segundo a raça, o sexo e a faixa etária. São Paulo, 2002.

QUADRO 10 Caracterização do plantel de caprinos da raça Alpina do Cabril 4, destacando o efetivo existente e do qual foram colhidas quatro amostras de soro sangüíneo. Estratificação segundo a raça, o sexo e a faixa etária. São Paulo, 2002.

QUADRO 11 Caracterização do plantel de caprinos Mestiços do Cabril 4, destacando o efetivo existente e do qual foram colhidas quatro amostras de soro sangüíneo. Estratificação segundo a raça, o sexo e a faixa etária. São Paulo, 2002.

QUADRO 12 Caracterização do plantel de caprinos do Cabril 5, destacando o efetivo existente e do qual foram colhidas quatro amostras de soro sangüíneo. Estratificação segundo a raça, o sexo e a faixa etária. São Paulo, 2002.

QUADRO 13 Caracterização do plantel de caprinos da raça Saanen do Cabril 6, destacando o efetivo existente e do qual foram colhidas quatro amostras de soro sangüíneo. Estratificação segundo a raça, o sexo e a faixa etária. São Paulo, 2002. 
QUADRO 14 Caracterização do plantel de caprinos da raça Alpina do Cabril 6, destacando o efetivo existente e do qual foram colhidas quatro amostras de soro sangüíneo. Estratificação segundo a raça, o sexo e a faixa etária. São Paulo, 2002.

QUADRO 15 Caracterização do plantel de caprinos da raça Alpina do Cabril 7, destacando o efetivo existente e do qual foram colhidas quatro amostras de soro sangüíneo. Estratificação segundo a raça, o sexo e a faixa etária. São Paulo, 2002.

QUADRO 16 Caracterização do plantel de caprinos da raça Saanen do Cabril 8, destacando o efetivo existente e do qual foram colhidas quatro amostras de soro sangüíneo. Estratificação segundo a raça, o sexo e a faixa etária. São Paulo, 2002.

QUADRO 17 Caracterização do plantel de caprinos da raça Boer do Cabril 8, destacando o efetivo existente e do qual foram colhidas quatro amostras de soro sangüíneo. Estratificação segundo a raça, o sexo e a faixa etária. São Paulo, 2002.

QUADRO 18 Caracterização do plantel de caprinos da raça Saanen do Cabril 9, destacando o efetivo existente e do qual foram colhidas quatro amostras de soro sangüíneo. Estratificação segundo a raça, o sexo e a faixa etária. São Paulo, 2002.

QUADRO 19 Caracterização do plantel de caprinos da raça Saanen do Cabril 10, destacando o efetivo existente e do qual foram colhidas quatro amostras de soro sangüíneo. Estratificação segundo a raça, o sexo e a faixa etária. São Paulo, 2002.

QUADRO 20 Caracterização do plantel de caprinos da raça Saanen do Cabril 11, destacando o efetivo existente e do qual foram colhidas quatro amostras de soro sangüíneo. Estratificação segundo a raça, o sexo e a faixa etária. São Paulo, 2002. 
QUADRO 21 Caracterização do plantel de caprinos da raça Anglo Nubiana do Cabril 11, destacando o efetivo existente e do qual foram colhidas quatro amostras de soro sangüíneo. Estratificação segundo a raça, o sexo e a faixa etária. São Paulo, 2002.

QUADRO 22 Caracterização do plantel de caprinos da raça Alpina do Cabril 11, destacando o efetivo existente e do qual foram colhidas quatro amostras de soro sangüíneo. Estratificação segundo a raça, o sexo e a faixa etária. São Paulo, 2002.

QUADRO 23 Caracterização do plantel de caprinos da raça Toggenbourg do Cabril 11, destacando o efetivo existente e do qual foram colhidas quatro amostras de soro sangüíneo. Estratificação segundo a raça, o sexo e a faixa etária. São Paulo, 2002.

QUADRO 24 Caracterização do plantel de caprinos da raça Saanen do Cabril 12, destacando o efetivo existente e do qual foram colhidas quatro amostras de soro sangüíneo. Estratificação segundo a raça, o sexo e a faixa etária. São Paulo, 2002.

QUADRO 25 Caracterização do plantel de caprinos da raça Anglo Nubiana do Cabril 12, destacando o efetivo existente e do qual foram colhidas quatro amostras de soro sangüíneo. Estratificação segundo a raça, o sexo e a faixa etária. São Paulo, 2002.

QUADRO 26 Caracterização do plantel de caprinos da raça Alpina do Cabril 12, destacando o efetivo existente e do qual foram colhidas quatro amostras de soro sangüíneo. Estratificação segundo a raça, o sexo e a faixa etária. São Paulo, 2002.

QUADRO 27 Caracterização do plantel de caprinos Mestiços do Cabril 12, destacando o efetivo existente e do qual foram colhidas quatro amostras de soro sangüíneo. Estratificação segundo a raça, o sexo e a faixa etária. São Paulo, 2002. 
QUADRO 28 Caracterização do plantel de caprinos da raça Saanen do Cabril 13, destacando o efetivo existente e do qual foram colhidas quatro amostras de soro sangüíneo. Estratificação segundo a raça, o sexo e a faixa etária. São Paulo, 2002.

QUADRO 29 Caracterização do plantel de caprinos da raça Boer do Cabril 13, destacando o efetivo existente e do qual foram colhidas quatro amostras de soro sangüíneo. Estratificação segundo a raça, o sexo e a faixa etária. São Paulo, 2002.

QUADRO 30 Caracterização do plantel de caprinos da raça Saanen do Cabril 14, destacando o efetivo existente e do qual foram colhidas quatro amostras de soro sangüíneo. Estratificação segundo a raça, o sexo e a faixa etária. São Paulo, 2002.

QUADRO 31 Distribuição dos cabritos criados e mantidos no CPDER/FMVZUSP, que constituíram 3 grupos experimentais para avaliar a transmissibilidade do vírus da Artrite-encefalite dos Caprinos, segundo o tipo de colostro e aleitamento que receberam. São Paulo, 2002.

QUADRO 32 Distribuição dos cabritos inoculados com efusões orgânicas, contendo o vírus da Artrite-encefalite dos Caprinos, segundo a via de inoculação e inóculo utilizado. São Paulo, 2002. 


\section{RESUMO}

LARA, M. C. C. S. H. Artrite-encefalite dos Caprinos - Aspectos clínicos e epidemiológicos. [Caprine arthritis encephalitis - Clinical and epidemiological features]. São Paulo, 2002. 247 f. Tese (Doutorado em Clínica Veterinária) - Faculdade de Medicina Veterinária e Zootecnia, Universidade de São Paulo, São Paulo.

Estudou-se a freqüência da ocorrência de anticorpos antivírus da Artrite-encefalite dos Caprinos, em caprinos de 14 plantéis localizados no Estado de São Paulo, por um período de 2 anos, utilizando-se a técnica de imunodifusão em gel de ágar. A prevalência obtida foi de $26,3 \%$, sendo significativamente maior nos caprinos mantidos em regime intensivo $(31,8 \%$ - 733/2303) de criação do que no sistema semi-extensivo (13,1\% - 128- 977). A infecção pelo vírus da Artrite-encefalite dos Caprinos aumentou gradativa e significativamente após os 6 meses de idade, havendo predominância da infecção nos caprinos mais velhos. Não se detectou influência de fatores sexuais sobre a prevalência da enfermidade determinada em caprinos do sexo feminino $(27,9 \%$ - 663/2375) e masculino $(32,3 \%$ 94/291). A prev alência da doença foi significativamente maior nos caprinos das raças Anglo Nubiana $(63,8 \%$ - 88/138) e Toggenbourg $(56,0 \%$ - 28/50) do que nas demais raças estudadas: Saanen (27,4\% - 673/2458), Alpina (11,9\% - 59/497), Bôer (5,9\% - 2/34) e caprinos mestiços (10,7\% 11/103). Paralelamente realizou-se estudo clínico dos animais infectados pelo vírus da Artriteencefalite dos Caprinos, quando pudemos demonstrar que 17,1\% (64/374) dos caprinos sororeagentes apresentavam a forma clínica articular da enfermidade e que 6,6\% (17/249) das cabras sororeagentes apresentavam a forma mamária. A possibilidade de transmissão vertical transplacentária foi menor do que $3,8 \%$. Verificou-se ser pequena a possibilidade dos cabritos se infectarem pelo colostro de cabras sororeagentes positivas, mas podem se infectar pelo leite oriundos dessas cabras infectadas $(18,8 \%$ 3/16). O tempo de duração dos anticorpos séricos adquiridos passivamente pelo colostro variou de 60 a 120 dias. Demonstrou-se, indiretamente, a presença e a viabilidade do vírus no sangue circulante, 
colostro e leite de caprinos infectados, bem como a possibilidadede infectar animais susceptíveis por inoculação, sendo o período de incubação de 45 a 60 dias. Não se demonstrou diferenças significativas dos teores séricos de proteína total, gamaglobulina e da atividade enzimática da glutamiltransferase $\gamma \mathrm{GT}$ em cabritos que receberam colostro de cabras infectadas ou não infectadas pelo mencionado vírus.

Unitermos: Artrite-encefalite dos Caprinos; Lentivírus; Caprinos; Infecção; Transmissão. 


\section{SUMMARY}

LARA, M. C. C. S. H. Caprine arthritis encephalitis - Clinical and epidemiological features. [Artrite-encefalite dos Caprinos - Aspectos clínicos e epidemiológicos]. São Paulo, 2002. 247 f. Tese (Doutorado em Clínica Veterinária) - Faculdade de Medicina Veterinária e Zootecnia, Universidade de São Paulo, São Paulo.

The frequency of occurrence of antibodies anti-caprine arthritis-encephalitis virus was studied in 14 herds in the State of São Paulo, during 2 years, using agar gel immunodiffusion. Prevalence was equal to $26.3 \%$, and was significantly higher in animals kept under an intensive management scheme $(31.8 \%$ - 733/2303), than in animals kept under a semi-extensive one (13.1\% - 128-977). Infection by the caprine arthritis-encephalitis virus increased gradual and significantly after 6 months of age. Infection was predominant in older animals. There was no gender influence on the prevalence of the disease, both in females $(27.9 \%$ - 663/2375) and males $(32.3 \%$ - 94/291). In relation to breed, prevalence of the disease was significantly higher in Anglo-Nubian (63.8\% - 88/138) and Toggenbourg animals (56.0\% - 28/50), than in the rest of the breeds studied: Saanen (27.4\% - 673/2458), Alpine (11.9\% - 59/497), Boer $(5.9 \%$ - 2/34) and mixed breed animals (10.7\% - 11/103). A clinical study of the animals infected by caprine arthritis-encephalitis virus was also performed. It was observed that $17.1 \%(64 / 374)$ of seroreagents presented the articular form of the disease and that $6.6 \%(17 / 249)$ of the seroreagent females presented the mammary form of the disease. The possibility of vertical, transplacentary transmission was lower than $3.8 \%$. It was observed that the probability of infection of kids by colostrum of infected females was low (18.8\% - 3/16). Antibodies passively acquired by colostrum ingestion lasted from 60 to 120 days. The presence and viability of the virus circulating in blood, colostrum and milk of infected 
animals, as well as the possibility of infection of susceptible animals by inoculation was indirectly demonstrated. Incubation period ranged from 45 to 60 days. There was no significantdifference in serum levels of total protein and gammaglobulin, and in enzymatic activity of glutamiltransferase $-\gamma \mathrm{GT}$ in kids that received colostrum from infected and non-infected females.

Uniterms: Caprine; Arthritis-encephalitis; Lentivirus; Caprines; Infection; Transmission. 


\section{SUMÁRIO}

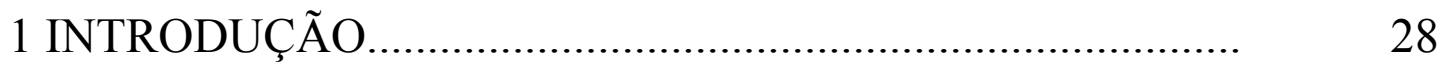

2 REVISÃO DE LITERATURA..............................................

3 MATERIAL E MÉTODOS....................................................

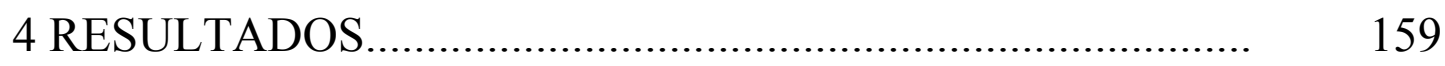

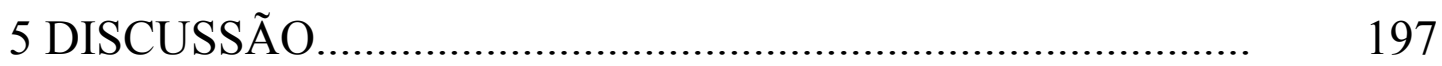

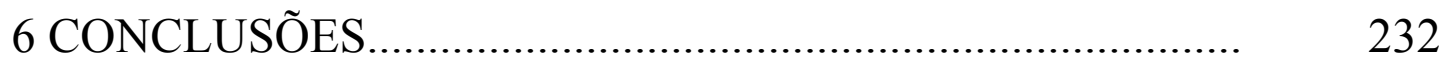

7 REFERÊNCIAS............................................................ 237 



\section{INTRODUÇÃ̃O}

A cabra (Capra hircus, Linnaeus, 1758) foi um dos primeiros mamíferos a ser domesticado pelo Homo sapiens e, seguramente foi essa espécie a primeira a lhe fornecer leite para sua alimentação, sendo criada pelos homens primitivos de várias civilizações. A história da humanidade demonstrou que a arte de criar caprinos remonta a 7000 anos antes de Cristo, estando associada à agricultura e à necessidade de plantar vegetais comestíveis, atendendo a necessidade de alimentar o homem de hábitos nômades que, gradativamente, tornava-se sedentário. Os primitivos habitantes de vários continentes tornaram-se pastores e agricultores, deixando de ser nômade, dedicado à pesca e à caça, acompanhando os rebanhos e outros agrupamentos animais em suas migrações na procura de melhores condições de vida e reprodução (CASTRO, 1984; VIEIRA, 1984).

A partir da Era Neolítica nenhuma civilização que se destacou na história da humanidade, deixou de criar animais para prover alimentação, trabalho, proteção e energia para as populações (CASTRO, 1984; VIEIRA, 1984).

Os caprinos foram espécimes considerados como os animais mais dóceis e úteis à espécie humana, tendo sido, como destacou-se anteriormente, o primeiro animal leiteiro conhecido e utilizado pelo homem. A cabra doméstica pertence a espécie Capra hircus selvagens: a Capra aegragus e possui três ancestrais primitivos de cabras ou cabra

Benzoar, oriunda do ocidente da Ásia; a Capra falconiere, formada em regiões mais orientais da Ásia e Índia e a

Capra prisca de Adamentz, já extinta e que parece ser do tronco mais antigo desse gênero animal (DEVENDRA e BURNS, 1983; VIEIRA, 1984). 
Indivíduos dessa espécie - Capra hircus, acompanhavam o homem em suas migrações, difundindo-se, assim, por todas as regiões do mundo, indiferentes às agruras do ambiente e do clima. Por interferência de fatores externos, como clima e fertilidade do solo, foram moldadas inúmeras raças de caprinos, sendo a maioria delas de formação mesológica. Mais recentemente, em eras modernas, apareceram grupos reduzidos de animais, constituídos por raças melhoradas, que resultaram da ação direta do homem por seleção de caprinos segundo algumas normas e cuja produção ultrapassava as necessidades de sobrevivência das crias e, o excesso de produção seria, então, aproveitado pelo homem na sua alimentação (DEVENDRA e BURNS, 1983; CASTRO, 1984).

Atualmente, os animais da espécie Capra hircus, de acordo com a especialização de suas produções, foram considerados como um fator econômico da pecuária, importante e fundamental, para grande maioria da população mundial, quer seja como fonte de carne, leite e fibras, ou às vezes, como animais de companhia. Em algumas circunstâncias, esses animais foram utilizados como oferenda de sacrifício em rituais religiosos, mas na maioria das vezes receberam grande distinção das populações, que as consideravam como "a vaca dos pobres", pois os caprinos sobreviviam em áreas inóspitas para os grandes ruminantes, ultrapassando assim, em inúmeras condições, os bovinos em importância, para um grande segmento da população (JARDIM, 1973; CASTRO, 1984).

O Brasil, com cerca de 8,6 milhões de cabeças, possui o nono maior rebanho caprino do mundo, mas, paradoxalmente, contribui com apenas $1,3 \%$ da produção mundial de leite de cabra (FAO, 1993; IBGE, 2001). O manejo inadequado, a falta de informação precisa sobre a fisiologia da reprodução e as necessidades nutricionais e o desconhecimento da 
etiopatogenia e metodologia do diagnóstico de inúmeras enfermidades infecto-contagiosas e parasitárias foram consideradas responsáveis pelo baixo rendimento do plantel brasileiro.

A caprinocultura desenvolveu-se, em quase todos os municípios dos Estados do Brasil, com diferentes sistemas de produção e variadas normas de manejo alimentar e sanitário; em conseqüência foram associados a esses fatores intrínsecos da produção outros, não menos importantes, relacionados à produtividade, à organização fundiária e a estrutura do capital produtivo de cada região. O rebanho nacional, segundo levantamentos estatísticos de populações, foi distribuído da seguinte forma: $2,1 \%$ na Região Sul; $2,4 \%$ na Região Sudeste; 0,9\% na Região Centro-Oeste; $93,2 \%$ na Região Nordeste e 1,4\% na Região Norte. O Estado de São Paulo é o segundo maior produtor da região Sudeste com plantel de 72.920 cabeças. O rebanho de caprinos leiteiros do Estado de São Paulo representa cerca de 0,9\% do rebanho nacional e 35,7\% do rebanho caprino da Região Sudeste; números que demonstram claramente a importância da caprinocultura paulista de leite para o país (IBGE, 2001).

No Brasil, a criação de caprinos destinada à exploração leiteira tem apresentado boa perspectiva econômica, decorrente da utilização do leite desses animais na fabricação de queijos finos e como opção para alimentação de populações de baixa renda, em virtude do seu grande valor nutritivo, apesar do pequeno custo de produção e venda, além de constituir-se em uma alternativa para pacientes com intolerância ao leite bovino. Com o aumento da produção de leite de cabra no Estado de São Paulo, representando significativo ganho econômico dos pecuaristas no agrobussines, os estudos e pesquisas relacionados à sanidade e ao controle de enfermidades nos rebanhos assumiu uma merecida posição de destaque, estimulando os Centros de Pesquisas em Universidades e Serviços das Secretarias da Agricultura instituírem programas específicos sobre patogênese e clínicas das inúmeras doenças que acometeriam, de forma mais ou menos freqüente, esses animais. As criações de 
São Paulo, num contexto amplo e atual da pecuária nacional, puderam ser assim caracterizadas: propriedades de pequeno porte localizadas próximas aos grandes centros urbanos e cuja exploração principal é a produção de leite. Os criadores, na maioria das vezes, utilizam a caprinocultura como segunda opção orçamentária dentro de seus programas de agropecuária, e na avaliação da produção desses rebanhos concluiu-se haver carência e deficiência de informações corretas sobre as práticas adequadas de manejo e de controles dietético, reprodutivo e sanitário. Isso tem sido destacado mesmo sabendo-se que os criadores estariam cientes que uma maior rentabilidade na produção de leite, apenas coexistiria com o bom estado sanitário dos rebanhos.

Entre os problemas infecciosos e parasitários, que por si só já se constituiriam em importantes fatores limitantes da expansão da caprinocultura no Estado de São Paulo, com implicações diretas na comercialização dos produtos e subprodutos, lácteos ou cárneos, bem como para a venda de reprodutores e matrizes, cabe destacar aquele que aflige, atualmente os caprinocultores: a Artrite-encefalite dos Caprinos (AEC), doença infecciosa de origem viral. Essa enfermidade é uma das maiores responsáveis pela limitação do desenvolvimento da criação produtiva de caprinos, em São Paulo e no Brasil. Levantamentos da taxa de prevalência desta virose, demonstraram que o agente está disseminado no rebanho caprino brasileiro, sendo, enzoótica, na maioria das regiões geoeconômicas e dos rebanhos, causando sérios prejuízos econômicos, por descartes prematuros, mortalidade e redução da produtividade. A Artrite-encefalite dos Caprinos foi caracterizada como doença infecciosa multissistêmica, causada por um vírus pertencente a família Retroviridae, do gênero Lentivirus, nomeado de vírus da Artrite-encefalite dos Caprinos, acometendo caprinos de todas as raças e idades, independendo do sexo e do sistema de criação. As principais manifestações clínicas observadas nesta virose foram: artrite e leucoencefalomielite, podendo, 
com menor freqüência, determinar alterações do sistema respiratório e da glândula mamária. As raças leiteiras no Estado de São Paulo concentraram, atualmente, a quase totalidade dos casos de infecção e/ou da doença. Estudos desenvolvidos para determinar o impacto econômico dessa virose, demonstrou a diminuição da produção leiteira, da eficiência reprodutiva e do aumento do descarte de caprinos infectados ou acometidos por uma das formas clínicas da Artrite-encefalite dos Caprinos (BOHLAND, 1998). Além do mais, os veterinários especializados no atendimento clínico de caprinos nos rebanhos brasileiros ressaltaram que pela ausência ou pela tomada de medidas sanitárias inadequadas, imprecisão de diagnóstico e deficiências teóricas e práticas do controle da Artrite-encefalite dos Caprinos em nossos criatórios, a doença se disseminou de forma alarmante. Acreditou-se, sem adequada contestação científica, que a via primária de transmissão do vírus da Artriteencefalite dos Caprinos para os cabritos seria a via colostral ou a ingestão de leite de cabras infectadas, pelo cabrito durante os primeiros meses de vida. Face a ampla distribuição geográfica dessa infecção viral, a Artrite-encefalite dos Caprinos foi considerada cosmopolita, isto é, a enfermidade descrita como enzoótica em vários países e no Brasil já foi relatada sua ocorrência em vários Estados, atingindo inúmeros rebanhos. Os sintomas da enfermidade foram associados a lesões anatomo-funcionais progressivas e severas, por envolverem em sua patogenia as células mononucleares, determinando processos inflamatórios das articulações, sistema nervoso central, pulmões e glândula mamária (CORK et al., 1974; CRAWFORD et al., 1980). A mastite intersticial endurativa foi considerada ocorrência marcante e freqüente nos rebanhos de caprinos leiteiros, com diminuição gradativa da produção láctea, apresentando por isso significado econômico pelas perdas determinadas, que talvez, ainda esteja sendo subestimado. A artrite constitui, entre as formas clínicas da doença, aquela que foi mais freqüentemente encontrada e descrita. Entretanto, grande número de animais infectados, durante longos períodos de decurso da doença, caracterizavam-se por serem 
assintomáticos, mas nesse período de tempo permaneceriam como carreadores do vírus. A maneira mais prática e mais recomendável para o estabelecimento do diagnóstico clínico e etiológico da Artrite-encefalite dos Caprinos foi aquela que combinou a avaliação clínica do paciente com os resultados de provas laboratoriais complementares imuno-sorológicas (OIE, 2000).

Pelo demonstrado significado da Artrite-encefalite dos Caprinos para a criação e produção de caprinos no Brasil, bem como pela ausência de informações precisas sobre as principais condições clínico-epidemiológicas da infecção nos referidos animais, julgou-se oportuno estudar algumas situações etiopatogênicas e sintomáticas dessa infecção, elucidando dentro de delineamentos experimentais propostos, várias questões sobre o desenvolvimento do quadro clínico em caprinos leiteiros criados no Estado de São Paulo.

$\mathrm{Na}$ proposta da pesquisa ora apresentada, idealizaram-se os seguintes objetivos:

- $\quad$ estudar a instalação e desenvolvimento da infecção e/ou da doença, relacionando-as às possíveis vias de transmissão do vírus da Artrite-encefalite dos Caprinos, pela ingestão de colostro e/ou leite de cabras infectadas, bem como avaliar-se a possibilidade da infecção transplacentária;

- $\quad$ estudar a transferência de imunidade passiva (de imunoglobulinas maternais) da cabra infectada para o cabrito neonato;

- estudo clínico e imuno-sorológico de caprinos naturalmente 
infectados pelo vírus da Artrite-encefalite dos Caprinos;

- avaliar fatores extrínsecos, como o sistema de criação e o manejo, que pudessem influenciar as taxas de infecção de caprinos suscetíveis pelo vírus causador da Artrite-encefalite dos Caprinos. 


\section{REVISÃO DE LITERATURA}

\subsection{Caracterização da doença causada pelo vírus da Artrite-encefalite dos Caprinos - Primeiro relato da enfermidade e isolamento do agente etiológico.}

Artrite-encefalite dos Caprinos (AEC), também conhecida pela sigla da abreviação da denominação da doença em inglês CAE (Caprine arthritis-encefalitis) foi caracterizada como uma enfermidade infecciosa, multissistêmica, causada por vírus pertencente ao gênero Lentivirus, que infecta caprinos de todas as idades, independente do sexo, raça e produção. As principais manifestações clínicas da doença descritas foram a leucoencefalomielite, que acomete cabritos (CORK et al., 1974) e a artrite, mais freqüente nos animais adultos (CRAWFORD et al., 1980). Além dessas formas clínicas bem definidas, os pulmões e a glândula mamária dos caprinos foram, também, descritos como passíveis de comprometimento nas infecções causadas pelo mencionado vírus determinando, respectivamente, uma pneumonia crônica intersticial, freqüentemente denominada por pneumonia progressiva dos caprinos (SIMS et al., 1983), e uma mamite intersticial endurativa(WOODARD et al., 1982; LERONDELLE et al., 1989; ROSADIO et al., 1993; SMITH e SHERMAN, 1994; SERAKIDES et al., 1996).

STÜNZI et al. (1964), relataram a ocorrência de artrites crônicas em cabras criadas na Suíça, destacando que tais casos clínicos eram conhecidos desde 1959. Em 1974, CORK et al. descreveram a ocorrência dos primeiros casos de leucoencefalomielite em 
cabritos com até 4 meses de idade, infectados natural ou experimentalmente pelo vírus da Artrite-encefalite dos Caprinos. Os cabritos doentes apresentavam ataxia e paralisia dos membros posteriores associadas a uma pneumonia intersticial, apesar dos animais permanecerem alertas, afebris e manterem o apetite. Na evolução do quadro clínico ocorria o decúbito e morte do animal, ou em alguns casos o estado geral do caprino doente recomendava seu abate. Face a evolução do caso clínico e a caracterização enzoótica da doença os mencionados, autores suspeitaram ser um vírus o agente etiológico desta doença, se contrapondo aos que relacionavam a doença a fatores hereditários.

O vírus causador da Artrite-encefalite dos Caprinos foi isolado pela primeira vez por CRAWFORD et al. (1980), de um bode com 8 anos de idade, apresentando manifestações clínicas evidentes de artrite crônica. $\mathrm{O}$ isolamento foi realizado a partir de explante da membrana sinovial, caracterizando-se a cultura celular do isolamento pela visualização no tapete de cultivo celular primário, num período de 4 semanas, do efeito citopático característico, pela formação de sincícios e vacuolização celular. Pela utilização de técnicas de microscopia eletrônica e de métodos bioquímicos específicos o vírus isolado em cultura de tecido (membrana sinovial) foi evidenciado e pode ser identificado como pertencente à família Retroviridae. A seguir, a amostra viral isolada foi inoculada em cabrito nascido por cesariana, que após o período de incubação apresentou lesões características de artrite nas articulações do carpo, similares àquelas apresentadas pelo animal adulto, de onde o vírus fora isolado. Desse animal inoculado, o vírus foi re-isolado, fechando-se o ciclo biológico do agente da Artrite-encefalite dos Caprinos. Os autores, anteriormente mencionados, relataram que a encefalomielite causada pelo vírus que isolaram, era 
semelhante à causada pelo vírus Maedi-visna dos Ovinos, e que resultados de testes imunológicos obtidos por imunodifusão, em gel de ágar, demonstravam similaridade antigênica dos dois vírus. A partir deste momento, histórico para a virologia dos caprinos, a enfermidade que fora, inicialmente, chamada de leucoencefalomielite dos caprinos, passou a ser denominada por Artrite-encefalite dos Caprinos.

\subsection{Caracterização do agente etiológico da Artrite-encefalite dos Caprinos - Etiopatogenia, sintomas e diagnóstico.}

O agente etiológico - Vírus da Artrite-encefalite dos Caprinos, causador da Artrite-encefalite dos Caprinos, foi classificado como pertencente à família Retroviridae, do gênero Lentivirus, agentes etiológicos de doenças de evolução lenta em várias espécies de animais domésticos (CRAWFORD et al., 1980; FRANCKI et al., 1991). A esta mesma família, Retroviridae, pertencem outros vírus de importância em patologia veterinária e humana: vírus da anemia infecciosa dos eqüinos; Maedi-Visna dos ovinos e os vírus causadores das imunodeficiências dos felinos (FIV); bovinos (BIV); símios (SIV) e humana (HIV) (ZANONI, 1993).

Na família Retroviridae foi descrito um grande número de vírus, caracterizados por uma morfologia comum: genoma constituído de fita simples de RNA e a presença, no vírus, de uma enzima, denominada transcriptase reversa, codificada pelo gene pol. Os Lentivírus foram também caracterizados por possuírem o gene gag, que codificaria as proteínas estruturais da cápside, e o gene env, que codificaria as glicoproteínas do envelope. No momento poderia afirmar-se, sem hesitação, que nenhum grupo de agentes infecciosas 
tem sido tão estudado quanto os vírus da família Retroviridae, pois eles foram descritos parasitando as mais diferentes espécies de vertebrados, indo na escala zoológica do peixe ao homem; além do mais, eles caracterizariam um gênero de vírus com capacidade de ser transmitido, tanto por via horizontal - entre companheiros de agrupamentos, como pela via vertical - através da placenta ou durante a geração de descendentes. Segundo pesquisas recentes, os vírus dessa família poderiam incorporar e transmitir seqüências do DNA do hospedeiro. O dogma central da genética molecular é o fluxo de informações genéticas caminharem do DNA para o RNA, a descoberta da enzima transcriptase reversa permitiu evidenciar um fluxo diferente de informação do RNA para o DNA. A existência desta enzima nesses vírus deu origem ao nome da família: Retroviridae, pois retro em latim significa retornar (COFFIN, 1996).

A família Retroviridae foi dividida em três subfamílias: Oncovirinae (do grego Onkos $=$ tumor) compreende os retrovírus oncogênicos, ou seja, aqueles capazes de causar crescimento desordenado das células onde se encontram, ocasionando leucemias, linfomas, tumores mamários e neurais; Lentivirinae (do latim Lenti = lento) agentes patológicos que não causavam transformações nas células, induzindo doenças de evolução crônica e degenerativas efinalmente, Spumavirinae (do grego Spuma = células espumosas) - os vírus desta subfamília foram encontrados, espontaneamente, em culturas de tecidos degeneradas causando alterações características, ou seja, presença de células gigantes vacuoladas e multinucleadas. Na última subfamília descrita, até o momento, não foi incluído nenhum vírus de importância que tenha demonstrado ser o agente etiológico de doença animal, ficando os 
relatos restritos à descrição de processos citopatológicos em culturas celulares (COFFIN, 1996).

Os retrovírus foram descritos como possuidores de duas enzimas principais: a transcriptase reversa, que converteria a fita simples de RNA em fita dupla de DNA e a integrase, responsável pela ligação do DNA viral ao DNA do hospedeiro, produzindo os Provírus (COFFIN, 1996). O ciclo de replicação desses vírus, segundo vários pesquisadores foi dividido em duas fases, a seguir esclarecidas. A primeira, incluindo a penetração da cápside no citoplasma da célula e a síntese de uma dupla fita de DNA a partir da fita única de RNA viral, e migração até o núcleo com sua incorporação ao DNA do genoma da célula hospedeira, por ação condicionada pela enzima integrase. As etapas e processos descritos ocorreriam sob a mediação das proteínas encontradas dentro do vírion, porém sem qualquer expressão gênica viral. Na segunda fase foi incluída a síntese e o processamento do genoma viral, RNA mensageiro e proteínas virais utilizando as várias estruturas organo-funcionais da célula, inclusive algumas polimerases celulares. Em muitos casos o processo de replicação não significaria a lesão da célula, que muitas vezes continuaria seu ciclo de multiplicação, reproduzindo as partículas virais sem maiores alterações morfológicas. O provírus, uma vez integrado à célula hospedeira, manter-se-ia estável, se replicando e passando para a progênie celular como um segmento do cromossomo (COFFIN, 1996; JOAG et al., 1996).

Algumas características importantes foram descritas nos vírus da família Retroviridae: o genoma contém duas moléculas idênticas de RNA de fitas simples ligadas por moléculas de hidrogênio na terminação 5'; serem os únicos vírus com genoma diplóide; a cápside possuir proteínas que lhe dariam conformação estrutural icosaédrica e de serem, 
também, antigênicas; constituírem partículas virais de aparência pleomórfica nos exames de ultramicroscopia, não revelando sempre a evidente simetria icosaédrica; e do envelope dos retrovírus, assim como outros vírus advirem do brotamento na membrana plasmática do hospedeiro, contendo lípides originais dessa membrana e componentes modificados pela inserção das proteínas virais na membrana citoplasmática da célula hospedeira (COFFIN, 1996).

Os lentivírus por serem envelopados demonstraram sensibilidade aos solventes orgânicos como detergentes, álcool, éter, amônia e fenóis, e a formalina e o hipoclorito, agiriam, também, como desinfetantes. Esses vírus foram, também, considerados susceptíveis à inativação em temperatura de $56^{\circ} \mathrm{C}$, durante 10 minutos (NARAYAN e CORK, 1990).

\section{Etiopatogenia da Artrite-encefalite dos Caprinos}

$\mathrm{Na}$ avaliação da patogenia do vírus causadores da Artrite-encefalite dos Caprinos demonstrou-se seu tropismo pelas células do sistema mononuclear fagocitário (monócitos e macrófagos), estimulando a produção de anticorpos contra as proteínas da cápside e das glicoproteínas do envelope do vírus. Esses anticorpos poderiam se associar aos macrófagos infectados pelo vírus, formando complexos imune antígeno-anticorpo. Suspeitouse que esses complexos fossem a base das alterações inflamatórias observadas nos tecidos comprometidos (EAST, 1996).

O vírus causador das infecções da Artrite-encefalite dos Caprinos foi considerados possuidores de três propriedades biológicas fundamentais que causariam a infecção persistente dos caprinos: 1) integração ao genoma, no DNA da célula hospedeira, 
desta forma eles evitariam sua eliminação pelo sistema imune; 2) replicação preferencial em macrófagos (NARAYAN et al., 1982) e; 3) não indução à formação de anticorpos neutralizantes (NARAYAN et al., 1980). As características retro definidas foram consideradas como aquelas que permitiriam a continuação de sua multiplicação independente de qualquer controle do sistema imune humoral do hospedeiro (NARAYAN e CORK, 1990; JOAG et al., 1996).

A exposição de caprinos ao vírus da Artrite-encefalite foi descrita e aceita como uma das formas de infecção sistêmica persistente, durante a qual o vírus infectaria e se replicaria em células da série monócito-macrófago, de forma pouco intensa. A seguir, foi descrita a ocorrência de viremia de pequena intensidade, principalmente quando o vírus estiver associado quase que exclusivamente aos monócitos. Estudos detalhados sobre esses monócitos infectados demonstraram que eles conteriam o genoma viral, mas não a partícula infecciosa. A cultura dessas células infectadas in vitro, provocariam a maturação celular, originando macrófagos e estes produziriam as partículas infecciosas (NARAYAN et al., 1983). Os monócitos foram considerados importantes no processo de disseminação da infecção para os vários tecidos orgânicos e, quando eles migram para órgãos específicos, originariam novos pontos de replicações do vírus. Reforçando essa afirmação, várias pesquisas demonstraram que em caprinos natural ou experimentalmente infectados o vírus causador da Artrite-encefalite pode ser isolado de monócitos e de macrófagos do baço, pulmão, do líquido sinovial e de macrófagos presentes no colostro e no leite de cabras lactantes (KENNEDY-STOSKOPF et al., 1985). 
Trabalhos iniciais de virologia da Artrite-encefalite dos Caprinos demonstraram que os macrófagos eram elementos importantes para a replicação do vírus, mas que a resposta imune dos animais infectados teria um papel crucial e preponderante na patogenia da doença. Como mencionado anteriormente, o fato do animal não desenvolver anticorpos neutralizantes antivírus da Artrite-encefalite dos Caprinos, foi considerado a razão da falha do sistema de defesa do hospedeiro, e esse mesmo fato, indiretamente, potencializaria a infecção persistente. A resposta imune celular também foi considerada possuidora de um papel importante no desenvolvimento da enfermidade por sua implicação direta nas injúrias orgânicas mediadas por células. A lesão básica nos órgãos afetados foi caracterizada por infiltração e proliferação de células mononucleares, associada à necrose das células constituintes dos tecidos desses órgãos, como exemplo clássico, pode-se destacar as células sinoviais das articulações (ADAMS et al., 1980).

Inúmeras pesquisas demonstraram que o vírus determinante da Artriteencefalite dos Caprinos poderia ser cultivado in vitro utilizando técnicas de explante ou de cocultivo em cultura celular pré-formada (NARAYAN e CORK, 1990). O explante pode ser realizado pelo cultivo de fragmentos de membrana sinovial, pulmão, plexo coróide e glândula mamária de caprinos infectados pelo vírus e o co-cultivo por inoculação de leucócitos, leite, colostro, ou fragmentos dos tecidos citados anteriormente, em culturas celulares pré-formadas de membrana sinovial de caprinos, ovinos ou de testículos de caprinos (SMITH e SHERMAN, 1994). Nas culturas celulares o efeito citopático foi caracterizado pela formação de sincícios, pois na replicação do vírus nessas culturas demonstrou-se a ocorrência de fusão celular (NARAYAN et al., 1980), mas também, foram visualizadas vacuolizações de células 
da cultura. $\mathrm{O}$ efeito citopático foi descrito como sendo ocorrência tardia, aparecendo após 4 semanas de cultivo. Semelhantes efeitos citopáticos não foram observados in vivo nas lesões observadas em casos clínicos de caprinos infectados pelo vírus da AEC (NARAYAN e CORK, 1990).

O vírus determinante da Artrite-encefalite dos Caprinos já foi isolado da membrana sinovial de animais que apresentavam artrite (CRAWFORD et al., 1980; OLIVER et al., 1982; ELLIS et al., 1983; RUSSO, 1983; SIMS et al., 1983; HÖTZEL et al., 1993; CASTRO et al., 1999b), do cérebro (KENNEDY-STOSKOPF et al., 1985), do plexo coróide (OLIVER et al., 1982; SIMS et al., 1983; AGRIMI et al., 1985; KENNEDYSTOSKOPF et al., 1985), de leucócitos do sangue periférico (PAWLISCH e MAES, 1984; KENNEDY-STOSKOPF et al., 1985; LERONDELLE et al., 1989; TEST et al., 1999; CASTRO et al., 1999b), do pulmão (SIMS et al., 1983; KENNEDY-STOSKOPF et al., 1985) e da glândula mamária (LERONDELLE et al., 1989).

\section{Considerações Clínico-Epidemiológicas da Artrite-encefalite dos Caprinos}

Apesar da extensa literatura existente, a Artrite-encefalite dos Caprinos foi considerada uma doença relativamente nova, e cujos aspectos clínico-epidemiológicos, ainda, mereceriam ser pesquisados. A razão dessa necessidade reside no fato do vírus poder causar diversos quadros clínicos, em animais de diferentes faixas etárias, caracterizando 4 formas clínicas: 1) leucoencefalomielite e pneumonia progressiva aguda, em recém nascidos e cabritos de até 4 meses de idade (CORK et al., 1987); 2) artrite crônica (CRAWFORD et al., 
1980); 3) mamite endurativa em cabras adultas (WOODARD et al., 1982); 4) pneumonia e encefalite progressiva crônica e esporádica, em animais adultos (SUNDQUIST et al., 1981).

As vias de transmissão determinantes da disseminação nos rebanhos de caprinos da Artrite-encefalite não foram, ainda, consideradas como definitivamente esclarecidas, mas os estudiosos do assunto consideraram a ingestão de colostro e leite de cabras infectadas como as formas mais importantes de transmissão da doença (CRAWFORD e ADAMS, 1981; ADAMS et al., 1983; EAST et al., 1987; ROWE et al., 1992). Isto poderia ocorrer tanto pelo fato do cabrito mamar diretamente na cabra, como também por alimentarse em sistema de amamentação coletiva, na qual o colostro ou leite proveniente de vários animais do rebanho, após mistura, seria administrado aos cabritos. O vírus teria condições de estar presente e viável nestas secreções lácteas, como vírus livre ou incorporado dentro de células somáticas, mantendo seu potencial de infectividade (SMITH e SHERMAN, 1994).

Alguns dos citados pesquisadores relataram que além da possibilidade da transmissão vertical do vírus da Artrite-encefalite dos Caprinos bem como pela amamentação materna do lactente a transmissão da infecção ocorreria, preferencialmente, no período pósnatal pela ingestão do colostro e do leite de cabras infectadas (CRAWFORD e ADAMS, 1981; ADAMS et al., 1983). Assim sendo, o aleitamento coletivo seria o responsável pela significativa prevalência da infecção nas criações dos caprinos leiteiros. Avaliações específicas sobre as possibilidades da transmissibilidade da infecção por ingestão de leite realizada por CRAWFORD e ADAMS (1981), demonstraram que cabritos, aos quais não era fornecido o colostro materno, de cabras infectadas, permaneciam livres da infecção por pelo 
menos 2 anos, enquanto cabritos criados, junto à própria mãe ou alimentados com colostro de animais infectados mostraram evidências da infecção por soro conversão, durante um período de até 60 dias.

A infecção pelo vírus da Artrite-encefalite dos Caprinos, poderia ocorrer, segundo a maioria dos pesquisadores, em qualquer fase da vida do animal, e em algumas pesquisas realizadas com cabritos alimentados com colostro de cabras sororeagentes positivas a esse vírus, submetido à ação do calor $-56^{\circ} \mathrm{C}$, durante uma hora, demonstraram que a persistência de anticorpos maternos antivírus da AEC, passivamente transferidos aos cabritos pela absorção de imunoglobulinas do colostro, variava entre 30 e 60 dias e, esses anticorpos não seriam mais detectados, quando os cabritos completassem 85 dias de vida (ADAMS et al., 1983; BULGIN, 1990). Mas, ELLIS et al. (1986) já haviam observado que a presença de anticorpos maternais antivírus passivamente transferidos pela ingestão do colostro, não impediriam a infecção desses cabritos pelo vírus da Artrite-encefalite dos Caprinos, o que aumentava sobremaneira as possibilidades da infecção por via horizontal.

Para comprovar a importância de transmissão do vírus causador da Artriteencefalite dos Caprinos pelo leite, foi realizada uma pesquisa com cabritos soronegativos alimentados com leite pasteurizado e não pasteurizado. O grupo de cabritos que foi alimentado com leite não pasteurizado teve uma taxa 3,3 vezes maior de soro conversões do que o outro grupo alimentado com leite pasteurizado (ROWE et al., 1991). Entretanto, as infecções pelo mencionado vírus em cabritos não pode ser explicada apenas pelo fato de haver ingestão de leite de cabras contaminado pois, posteriormente o mesmo grupo de pesquisadores demonstraram que cabritos filhos de mães soropositivas apresentavam uma taxa de soroconversão de até $10 \%$ aos 6 meses de idade, mesmo se alimentado com leite pasteurizado (ROWE et al., 1992). Por isso, tem sido considerado que a infecção peri-natal 
poderia ocorrer pelas seguintes vias possíveis de transmissão: transmissão intra-uterina e transmissão da mãe ao cabrito, no momento do parto, por contato com as secreções das vias fetais moles; pela ingestão acidental de colostro e pela exposição do cabrito às secreções respiratórias e à saliva da mãe, pelo hábito dela lamber seu cabrito, imediatamente, após o parto (ADAMS et al., 1983).

$\mathrm{Na}$ avaliação da transmissibilidade do vírus da Artrite-encefalite dos Caprinos levantou-se a suspeita de ocorrência da transmissão vertical do vírus, ou seja, transmissão transplacentária ou uterina durante o parto, porém as pesquisas não comprovaram, de forma irrefutável, essa hipótese. NARAYAN e CORK (1990) relataram que a infecção transplacentária do feto, por sangue maternal virêmico parece não ser a via de maior importância na disseminação causadora dessa infecção nos caprinos. Os referidos pesquisadores acreditaram que a exposição dos cabritos recém-nascidos ao vírus e suas partículas infectantes presentes no colostro, provavelmente seriam as maiores responsáveis pela grande incidência da leucoencefalomielite observada em cabritos lactentes.

EAST (1996) afirmou que o vírus causador da Artrite-encefalite dos Caprinos não pôde ser isolado no sêmen de bodes infectados pelo vírus e, portanto, a transmissão por essa via não deveria ocorrer. Em contraposição a essa afirmação, TRAVASSOS et al. (1999) trabalhando com 15 amostras de sêmen de bodes soropositivos aos antígenos do retromencionado vírus, conseguiram isola-lo, por co-cultivo, em cultura celular primária de membrana sinovial de caprinos de três amostras de sêmen. Além do mais, esses pesquisadores puderam detectar a presença do vírus no sêmen de 8 bodes, utilizando-se técnicas de PCR 
(reação em cadeia da polimerase), sugerindo por isso, existir possibilidade da transmissão sexual do vírus da Artrite-encefalite dos Caprinos.

Apesar dos fatos relatados anteriormente, a transmissão sexual do vírus ainda está sendo estudada, acreditando alguns pesquisadores que macrófagos infectados presentes na superfície da membrana mucosa dos órgãos do sistema genital poderiam veicular o vírus e transmitir a infecção durante a monta (NARAYAN e CORK, 1990). Em pesquisa realizada por ROWE et al. (1991) foi observado que algumas cabras soroconverteram entre 100 e 140 dias após terem sido cobertas por bodes soropositivos, suspeitando-se que a transmissão ocorreu pela cópula, no momento da monta natural. Semelhante conceito poder-se-ía afirmar ao considerarem as afirmações feitas em 1983 por ADAMS et al., sobre a transmissão do vírus por via intrauterina para o feto, e a infecção do neonato durante a sua passagem pelas vias fetais moles (canal cervical, vagina e vulva), durante o parto, pois apenas dois cabritos de 37 cabritos filhos de cabras soropositivas, nascidos por cesariana, tornaram-se sororeagentes ao vírus da Artrite-encefalite dos Caprinos. Os autores relataram que os dois animais teriam se contaminado tanto no interior do útero, como durante ou após o parto, já que um dos cabritos tornou-se sororeagente aos 4 meses de idade e o outro aos 32 meses, vale ressaltar que os animais, durante esses períodos, foram mantidos separados de animais sororeagentes e a eles fora administrado plasma de cabras soronegativas e leite de vaca pasteurizado, durante seus aleitamentos.

Pesquisas clínico-epidemiológicas, avaliando a prevalência de cabras soropositivas ao vírus a Artrite-encefalite dos Caprinos, em rebanhos criados e mantidos na Califórnia, EUA, com a intenção de controlar a infecção nos criatórios locais, recomendavam 
a alimentação dos cabritos com colostro e leite tratados pelo calor, demonstrando ao final que a soroconversão ainda ocorria, porém mais tardiamente, em alguns cabritos, particularmente quando um caprino adulto soropositivo permanecia no rebanho. Tal observação permitiu acreditar-se que a soroconversão estava relacionada à transmissão horizontal pelo contato direto dos cabritos com companheiros de rebanho infectados, principalmente se houvesse contato físico ou aglomeração de caprinos (WOODARD et al., 1982; ADAMS et al., 1983; EAST et al., 1987).

Outros mecanismos possíveis de transmissão horizontal do vírus causador da Artrite-encefalite dos Caprinos mencionados por alguns estudiosos do tema incluiriam: a exposição dos animais susceptíveis aos alimentos contaminados, água ou rações e forragens conspurcadas por secreções infectadas pelo vírus; exposição a aerosóis contendo partículas virais; o uso seriado de seringas, agulhas e tatuadores contaminados com sangue de caprinos infectados (SMITH e SHERMAN, 1994). Esses modernos conceitos sobre a transmissibilidade do vírus da Artrite-encefalite dos Caprinos se contrapuseram às afirmações que foram feitas por PERRIN e POLACK (1987) negando que a transmissão iatrogênica pudesse se constituir num fator de risco para disseminação da enfermidade.

Atualmente considerou-se que os sistemas de manejos influiriam sobremaneira na velocidade disseminação do vírus da Artrite-encefalite dos Caprinos nos rebanhos, ressaltando que as populações de caprinos criadas em sistemas que não envolviam o confinamento dos animais apresentavam menores taxas de prevalências dessa infecção (GREWAL et al., 1986; SURMAN et al., 1987).

No momento foi aventada a possibilidade da transmissão do vírus da Artriteencefalite dos Caprinos, entre cabras em lactação, por transferência de células infectadas de uma cabra lactante a outra, durante o processamento da ordenha. Tal fato foi comprovado 
experimentalmente, com pesquisa envolvendo 4 cabras da raça Saanen soronegativas que foram infectadas por inoculação de células infectadas pelo vírus diretamente no canal do teto. Infecção demonstrada tanto pela soroconversão dos animais, pelo isolamento do vírus a partir de sangue periférico, como também pela evidenciação de lesões típicas da doença no tecido mamário (LERONDELLE et al., 1995). Os fatores de risco associados à transmissão horizontal do vírus pela ingestão de leite infectado e seu relacionamento com o mau uso de

ordenhadeiras e à falta de higiene no procedimento, como mãos e toalhas sujas e contaminadas, anteriormente já haviam sido destacadas por ROWE et al. (1991).

O motivo de alguns rebanhos possuírem quase a totalidade dos efetivos infectados pelo vírus da Artrite-encefalite dos Caprinos tem sido explicado e atribuído ao fato da infecção poder persistir por toda vida do animal e apresentar, inúmeras vezes, uma evolução assintomática ou não diagnosticada tornando esses animais disseminadores do vírus e da doença (NARAYAN e CORK, 1990).

\section{Formas clínicas e sintomas de Artrite-encefalite dos Caprinos}

As primeiras informações sobre uma enfermidade enzoótica articular de caprinos, com descrição dos sintomas, das alterações anatomo-patológicas, bem como das tentativas para o estabelecimento de metodologia diagnóstica, associadas a recomendações para esclarecimento da etiologia foram apresentadas por STÜNZI et al. (1964), que citaram trabalho pioneiro de BÖNI (1961) sobre manifestações clínicas em casos de poliartrite dos caprinos, publicada na Academia de Ciências da Suíça. Segundo STÜNZI et al. (1964) a doença denominada por "Artrite Crônica Endêmica dos Caprinos" era considerada como de origem hereditária, com ocorrência freqüente em alguns fatos de caprinos da cidade de Altendorf, existindo no cantão suíço de Schwyz uma região caracterizada pela ocorrência 
enzoótica da artrite dos caprinos. Os mencionados pesquisadores tiveram oportunidade de examinar inúmeros casos clínicos no Hospital Veterinário de Zurique (Zürich); na oportunidade descreveram que as alterações da articulação carpal, caracterizadas por aumento de volume circular da articulação. As lesões se iniciavam na face extensora da articulação, atingindo um ou os dois membros anteriores. Por sugestão pessoal de BÜCHI (1959), realizaram a medição do perímetro do carpo - em caprinos sadios e doentes, demonstrando que essa avaliação apresentava pequena possibilidade de erro, servindo perfeitamente para o diagnóstico da lesão articular. Exames anatomo-patológicos - macro e microscópicos, bem como radiológicos, demonstravam a presença de periartrite com espessamento capsular, associada a deposições minerais e edema de tecido conjuntivo; não eram significativas as alterações das membranas sinoviais, como também não se observava significativo aumento de líquido sinovial. Exames bacteriológicos não demonstraram, em 4 caprinos, a ação de bactérias, princi palmente, não fora detectada a participação de agentes patológicos do gênero Mycoplasma, apesar de algumas cabras apresentarem agalaxia. A grande freqüência de caprinos acometidos pela artrite crônica carpal, em alguns plantéis e a não ocorrência da doença em outros, não permitia que fosse descartada a hipótese de sua origem hereditária. Todavia o aparecimento tardio das alterações articulares, de modo geral em animais com mais de 10 meses até 8 anos de idade, sugeria a existência da ação relevante de fatores ambientais, não conhecidos, naquele momento. Ocorrendo essa artrite crônica dos caprinos em outros cantões suíços, acometendo animais da raça Toggenbourg, STÜNZI et al. (1964) recomendaram que fossem conduzidas pesquisas de virologia e de transmissibilidade, como também se pesquisasse a constituição da água e dos alimentos utilizados nessas criações. Os mencionados pesquisadores recomendaram denominar-se a enfermidade como "Periartrite Crônica dos Caprinos".

$\mathrm{Na}$ evolução da infecção pelo vírus da Artrite-encefalite dos Caprinos foram 
observadas e descritas diversas formas clínicas da enfermidade. A forma clínica articular foi considerada a mais freqüente, todavia aquelas caracterizadas por sintomatologia nervosa, respiratória e mamária também poderiam ocorrer, isoladas ou associadas. A forma clínica articular, caracterizada por artrite progressiva, foi descrita em animais adultos com mais de 6 meses de idade (EAST, 1996), entretanto a taxa de maior prevalência fora estimada como ocorrendo, de forma predominante, em caprinos com idades variantes de 2 a 9 anos de idade (NARAYAN e CORK, 1990).

\section{Forma clínica articular}

O desenvolvimento da doença foi caracterizado como insidioso pois, geralmente, progride lentamente, por um longo período de tempo, indo de meses a anos, sem serem destacadas manifestações clínicas alarmantes. Em estudo realizado com caprinos criados em Washington, EUA, observou-se que a forma clínica articular da Artrite-encefalite dos Caprinos poderia aparecer repentinamente em alguns animais, permanecendo a seguir estática, enquanto que, em outros casos, após a instalação dos sintomas, a evolução e agravamento das manifestações progredia rapidamente; entretanto, em alguns desses casos clínicos observava-se evolução lenta, mas progressiva, podendo ser acompanhada durante vários anos (NARAYAN e CORK, 1990). As articulações do carpo (radio-carpiana, intercarpiana e carpo-metacarpiana) foram consideradas as mais comumente afetadas. Com menor freqüência descreveram-se artrites de outras articulações: do jarrete (tíbio-tarsiana, intertarsiana e tarso-tarsiana), patelar (femuro-rotuliana e femuro-tibial) e a atlanto-occiptal. Com o evoluir da doença, descreveram-se: aumento de volume da articulação, agravamento evidente do caso clínico, caracterizado por claudicação intensa, dificuldade do animal para 
deitar e se erguer e, conseqüentemente, haveria evidente emagrecimento. O líquido sinovial aumentaria em volume, mas na maioria das vezes o aumento da região ocorreria pela hiperplasia da cápsula articular e dos tecidos tendinoso e conjuntivo associados à articulação comprometida; dor articular, causando restrição dos movimentos, determinando atitudes e aprumos anormais, como por exemplo, genuflexão temporária ou permanente ou locomoverse apoiando, os membros anteriores sobre a face extensora da articulação do carpo. Finalmente, demonstrou-se a ocorrência da anquilose da articulação e calosidades da face, permanentemente, fletida da articulação ou erosões na pele que a recobre (EAST, 1996). NARAYAN e CORK (1990), anteriormente, haviam afirmado que, na dependência da severidade do quadro clínico, alguns caprinos acometidos mostravam sinais, variando de claudicação à relutância em caminhar, podendo ocorrer restrição severa de movimentos articulares, permanecendo, então, o animal em decúbito. A restrição de grau variado da locomoção causaria crescimento irregular dos cascos, e a decumbência algumas vezes causaria, na região, mantida em permanente contato com o solo, ulceração, formação de abscessos e osteomielite. A gravidade das lesões nas descrições de casos clínicos objetivos foi considerada diretamente proporcional à duração da evolução da doença, quanto mais longa a evolução da enfermidade, maior seria o dano ao tecido afetado (NARAYAN e CORK, 1990). Com exceção dos casos que apresentam complicações sépticas, os caprinos infectados pelo vírus determinante da Artrite-encefalite não demonstrariam as típicas manifestações do síndrome febre e, apesar de emagrecimento, mesmo em decúbito, manteriam o apetite, estando atentos ao que ocorre na sua circunvizinhança (NARAYAN e CORK, 1990).

$\mathrm{Na}$ fase inicial da artrite, ocorreria aumento excessivo de líquido sinovial, que causaria distenção da cápsula articular. Esse líquido foi descrito como menos viscoso do que o de articulações sadias e sua coloração variaria do amarronzado ao avermelhado, com significativo aumento do número de células sinoviais. Em condições normais, o conteúdo 
celular foi menor (500 células por $\mathrm{mm}_{3}$ ) do que o observado em casos de artrite agudas determinada pelo vírus da Artrite-encefalite dos Caprinos (até 500.000 células por $\mathrm{mm}^{3}$ ), sendo $90 \%$ dessas células mononucleares e em sua maioria linfócitos, com presença de conteúdo amorfo com características tintoriais eosinofílicas (CRAWFORD e ADAMS, 1981; WOODARD et al., 1982; NARAYAN e CORK, 1990). Na avaliação do conteúdo da cavidade articular infectada foi demonstrado líquido sinovial com fibrina, fragmentos da membrana sinovial e mineralização de fragmentos de membranas ou conglomerados de fibrina (NARAYAN e CORK, 1990). Na inflamação crônica da articulação, nos casos de Artrite-encefalite dos Caprinos, destacou-se que o líquido sinovial não tinha seu volume aumentado e apresentava coloração clara, com pequena celularidade, entre 100 e 500 células por $\mathrm{mm}_{3}$ (CRAWFORD e ADAMS, 1981).

\section{Forma clínica nervosa}

A leucoencefalomielite constitui a forma clínica nervosa da Artrite-encefalite dos Caprinos, sendo sua ocorrência predominante em cabritos com idades variando de 1 a 4 meses de idade (CORK et al., 1974; GEORGE, 1996). Da mesma forma do que foi ressaltado na Suíça, em 1964 (STÜNZI et al., 1964), também nos EUA deu-se destaque aos sintomas articulares dessa virose dos caprinos, pois eles foram os primeiros a serem descritos nesse país, em 1974, por CORK et al., mas quando nos casos clínicos apareciam os primeiros sinais neurológicos, a doença evoluía rapidamente, determinando paralisias entre 2 e 4 semanas de evolução (NARAYAN e CORK, 1990). No desenvolvimento das formas clínicas nervosas da Artrite-encefalite dos Caprinos, entre os principais sintomas foram destacados: fraqueza muscular, paresia ou ataxia dos membros posteriores - uni ou bilateral; alguns animais apresentavam andar em círculo e cegueira, em semanas observava-se progressão e agravamento das manifestações clínicas, atingindo os membros anteriores; os cabritos com 
tetraplegia permaneciam em decúbito lateral, evoluindo o quadro clínico para a morte ou sacrifício por questões humanitárias. Entretanto, se os cabritos recebessem os devidos cuidados veterinários e de tratamento fisioterápico e dietético eles se recuperavam da fase aguda da doença e sobreviviam, porém muitos apresentavam seqüelas das lesões nervosas, como paralisia, torcicolo e desvios de posição da cabeça. Os animais adultos com encefalomielite causada pelo vírus da Artrite-encefalite dos Caprinos apresentavam atrofia muscular. Na evolução da doença, em sua forma clínica nervosa, os animais não apresentavam a sindrome febre, permanecendo alertas e com apetite (NARAYAN e CORK, 1990). Outras manifestações clínicas observadas e descritas foram: nistagmo; tremores; inclinação da cabeça; trismo; movimentos anormais da cabeça (tique nervoso) e aumento da salivação (CORK et al., 1974; CORK, 1976). Recentemente, foi estabelecido como conceito clínico que a diversidade das manifestações clínicas descritas no decurso da Artrite-encefalite dos Caprinos estaria relacionada com a variabilidade da localização das lesões determinadas pelo vírus no sistema nervoso central (GEORGE, 1996).

\section{Forma clínica mamária}

A glândula mamária, em casos clínicos de Artrite-encefalite dos Caprinos, foi considerada passível de apresentar lesões determinadas pelo agente etiológico dessa doença. Tais lesões caracterizariam um processo inflamatório crônico (NARAYAN e CORK, 1990), determinando o que se denominou por mamite intersticial endurativa ou endurecimento do úbere. Nessas condições a consistência da glândula mamária apresentava-se dura à palpação, apesar da aparência macroscópica do leite não revelar qualquer tipo de anormalidade, mas observava-se diminuição da produção láctea, de forma gradativa, atingindo o grau máximo na agalaxia (EAST, 1996). 


\section{Forma clínica pulmonar}

Outra forma de Artrite-encefalite dos Caprinos descrita, foi caracterizada por seus sintomas respiratórios dominantes, e por isso considerada uma forma clínica pulmonar. As lesões do parênquima e interstício pulmonar causariam a pneumonia intersticial progressiva. Esta forma crônica de pneumonia foi considerada similar às descritas em ovinos, nas infecções pelo vírus Maedi-visna, na qual o sinal clínico mais evidente foi considerado a intensa dispnéia (PÉTURSSON et al., 1992). Os sintomas mais significativos descritos nas formas clínicas pulmonares da Artrite-encefalite dos Caprinos foram os seguintes: aumento da freqüência respiratória; intolerância ao exercício, após o qual alguns animais apresentariam intensa dispnéia, com atitudes e fascies característica com evidente projeção da língua para fora da cavidade bucal, no intuito de favorecer a respiração; tosse seca, quando presente não produtiva, pois não há catarro para ser expelido; não houve destaque para a ocorrência do sindroma febre a não ser que houvesse associação de infecções bacterianas secundárias; na auscultação da área pulmonar observou-se intensificação dos ruídos pulmonares, com modificação de timbre - respiração rude (SIMS et al., 1983).

\section{Lesões da Artrite-encefalite dos Caprinos}

As alterações histopatológicas observadas em casos iniciais de artrite foram caracterizadas por proliferação da membrana sinovial, com desenvolvimento de projeções das vilosidades sinoviais para o lúmen da articulação, associadas a uma resposta inflamatória, com intensa infiltração de linfócitos, macrófagos e células plasmáticas, principalmente entre as vilosidades, na região perivascular. Nas formas crônicas de artrites as lesões foram 
caracterizadas pela necrose de estruturas colagenosas, incluindo a cápsula articular, tendões, bainhas tendinosas, ligamentos e bolsas serosas. As células inflamatórias nesses tipos de lesões, na maioria das vezes, apresentariam organização ao redor de centros germinativos, onde as células plasmáticas seriam predominantes. Lesões mais severas se manifestariam apresentando necrose extensa, com mineralização das bridas necróticas, com subseqüente fibrose (ADAMS et al., 1980; CRAWFORD et al., 1980; NARAYAN e CORK, 1990).

As alterações patológicas no sistema nervoso foram consideradas como oriundas de encefalomielite desmielinizante, onde, entre as lesões microscópicas se incluiriam: acúmulo perivascular de células mononucleares; desmielinização na região subependimal; aumento de astrócitos da neuroglia e meningite mononuclear (CORK et al., 1974; CORK, 1976; CRAWFORD e ADAMS, 1981). Os focos inflamatórios eram predominantemente compostos por macrófagos (NARAYAN e CORK, 1990). Durante a fase aguda da doença, foi descrita na constituição celular do líquido cefaloraquidiano a ocorrência de pleocitose, atingindo-se valores iguais a 100.000 células mononucleares por $\mathrm{mm}^{3}$ de líquor. Ainda, foram observadas, nesses casos, lesões, caracterizadas por acúmulo perivascular de células mononucleares, que aprofundando-se poderiam atingir até o parênquima, sendo a inflamação acompanhada pela destruição da mielina e proliferação das células da neuroglia. Nos estágios mais avançados as célula inflamatórias se organizariam em centros germinativos ou acúmulos focais de células da glia (NARAYAN e CORK, 1990). 
A mastite intersticial endurada causada pelo vírus da Artrite-encefalite dos Caprinos foi caracterizada como inflamação não supurativa, com infiltração difusa de células mononucleares, no parênquima glandular. As lesões se constituiriam de intensa hiperplasia linfocitária, que em casos crônicos se tornariam nódulos linfóides e muitos desses nódulos se localizariam em áreas adjacentes aos dutos lactíferos (PÉTURSSON et al., 1992). Anteriormente, já fora descrito que as células inflamatórias eram do mesmo tipo que as observadas nas articulações acometidas por artrite, determinadas pela ação deletéria do vírus em questão, ou seja, eram linfócitos e macrófagos (NARAYAN e CORK, 1990).

Em casos de pneumonia intersticial causada pelo vírus da Artrite-encefalite dos Caprinos durante a realização de necropsias, os pulmões estavam completamente colabados, densos, apresentando na superfície áreas de coloração cinza, firme à palpação. Ao corte dos pulmões não se constatava a presença de exsudato. Além do mais, nesses casos, não se descreveram alterações na pleura, porém os linfonodos do mediastino estavam aumentados de volume (SIMS et al., 1983). A pneumonia intersticial progressiva, causada pela infecção do vírus da Artrite-encefalite dos Caprinos, poderia afetar tanto os lobos caudais, como os crânio-ventrais. Do ponto de vista histopatológico, as lesões se caracterizariam por: infiltração linfocitária focal e difusa, dos septos alveolares; acúmulo de material eosinofílico no interior dos alvéolos pulmonares; adelgaçamento do septo alveolar e epitelização alveolar (SIMS et al., 1983; ELLIS et al., 1988; NARAYAN e CORK, 1990). Pode-se observar grande proliferação de pneumócitos do tipo II e acúmulo de substância surfactante no interior dos alvéolos, fatos que caracterizariam a pneumonia intersticial crônica (ELLIS et al., 1988). 


\section{Provas imuno-sorológicas para evidenciação da infecção pelo vírus da Artrite- encefalite dos Caprinos}

Os caprinos infectados por esse vírus nem sempre apresentariam alterações clínica evidentes, por isso recomendou-se que o diagnóstico da Artrite-encefalite dos Caprinos fosse padronizado, baseando-se o exame clínico, tanto nos antecedentes, no histórico do caso clínico e na avaliação física do doente, como também em resultados de exames laboratoriais, principalmente, em provas imuno-sorológicas para detecção dos anticorpos de origem viral (CRAWFORD e ADAMS, 1981).

A avaliação laboratorial imuno-sorológica para detecção da infecção pelo vírus da Artrite-encefalite dos Caprinos, tem sido feita de duas formas: por técnicas diretas ou indiretas. A detecção direta da presença do vírus no organismo do caprino, pode ser realizada, tanto pelo isolamento do agente etiológico da doença, em cultura celular (CRAWFORD et al., 1980; OLIVER et al., 1982; RUSSO, 1983; SIMS et al., 1983; HÖTZEL et al., 1993; CASTRO et al., 1999b), por evidenciação do vírus em microscopia eletrônica (ELLIS et al., 1983), como também por reação em cadeia de polimerase - PCR (RIMSTAD et al., 1993; CLAVIJO e THORSEN, 1996) ou pela técnica da hibridização in situ (ZINK et al., 1990). Por outro lado, a determinação indireta da infecção dos caprinos pelo vírus da Artriteencefalite tem sido feita pela detecção da presença de anticorpos séricos específicos por técnicas soro-imunológicas como: imunodifusão em gel de ágar (CUTLIP et al., 1977; CRAWFORD e ADAMS, 1981; ADAMS et al., 1985); ensaio imunoenzimático - ELISA 
(ELLIS et al., 1983; ARCHAMBAULT et al., 1988; ZANONI et al., 1989; HÄNEL, 1991; HECKERT et al., 1992; CASTRO et al., 1999a; SAMAN et al., 1999); imunofluorescência indireta (REISCHAK, 2000) e Western Blot (ZANONI et al., 1989; RIMSTAD et al., 1993). Devido a praticidade de colheita das amostras de soro sangüíneo e ao custo reduzido para a realização das mencionadas provas, os métodos sorológicos foram amplamente recomendados e utilizados para auxiliar o diagnóstico da infecção pelo vírus da Artrite-encefalite dos Caprinos (KNOWLES, 1997).

Por se tornarem os caprinos persistentemente infectados após a exposição ao vírus causador da Artrite-encefalite, a demonstração da ocorrência de anticorpos antivírus da AEC indicaria a condição de infectado do animal. A prova de imunodifusão em gel de agar foi considerada como o teste padrão para a demonstração de anticorpos antivírus da Artriteencefalite dos Caprinos (CRAWFORD e ADAMS, 1981) e por isso seu uso no controle da doença tem sido amplamente utilizado e recomendado pelos laboratórios de imunologia dos Estados Unidos da América e de vários países da Europa (NARAYAN e CORK, 1990). A técnica do ensaio imunoenzimático (ELISA) foi considerada mais sensível, mas somente no momento a sua eficácia foi avaliada (HOUWERS et al., 1982).

O índice clínico articular (ICA), considerado eficiente para o diagnóstico clínico da artrite, foi descrito, primeiramente, por MONICAT (1987) e a seguir por PERRIN et al. (1988), apesar dessa medida ter sido recomendada por STÜNZI et al., 1964, para o diagnóstico da artrite crônica enzoótica dos caprinos, criados na Suíça. Por esse método poder-se-ia caracterizar as manifestações clínicas de artrite em caprinos e recomendou-se que 
o Índice Clínico Articular fosse determinado pela diferença dos perímetros da articulação carpo-cubital e da diáfise proximal do osso do metacarpo. Na interpretação do índice foi preconizado: que diferença igual ou menor do que $5,5 \mathrm{~cm}$, corresponderia a resultado negativo; quando ela variasse entre 6,0 e $6,5 \mathrm{~cm}$ o resultado seria considerado suspeito e, quando fosse igual ou maior do que 7,0 cm, o resultado confirmaria a ocorrência da artrite. Apesar do índice positivo caracterizar de forma absoluta a ocorrência clínica de uma artrite, não apresentaria acuidade suficiente e nem seria seu objetivo a determinação do diagnóstico etiológico da enfermidade, ou seja, afirmar-se a existência de infecção determinada pelo vírus causador da Artrite-encefalite dos Caprinos. No Brasil, houve tentativa de contestação do uso clínico da medição do perímetro da articulação carpo-cubital e da diáfese do metacarpo, pois como método isolado ela seria incapaz de estabelecer o diagnóstico da infecção causada pelo vírus da Artrite-encefalite dos Caprinos (GARCIA et al., 1992b), pois em inúmeros casos clínicos de artrite dos caprinos, foram confirmadas as suspeitas que outras doenças pudessem, em algumas circunstâncias, determinar essas inflamações articulares e, assim sendo, assemelhar-se-íam sintomatologicamente com a forma clínica articular da Artrite-encefalite dos Caprinos. Nesses casos, foram incluídas as infecções causadas pelo Mycoplasma sp (ROSSINI et al., 1986). Entretanto, os resultados apresentados na pesquisa de RAMALHO (2000) permitiram afirmar-se que, apesar de existirem inúmeras formas de artrites em caprinos, não atribuíveis às infecções virais e/ou bacterianas, a maioria dos casos clínicos examinados, apresentando Índice Clínico Articular positivo, poderia ser atribuída à ação deletéria do vírus da Artrite-encefalite dos Caprinos e as lesões articulares primárias que o vírus causaria nas diferentes estruturas da articulação poderiam ser consideradas fatores 
predisponentes ao desenvolvimento local do Mycoplasma mycoides subespécies mycoides, agravando secundariamente as lesões articulares. De fato, as manifestações clínicas articulares pelo vírus causador da Artrite-encefalite dos Caprinos poderia, ainda, ser confundida com as conseqüentes às ações deletérias do Mycoplasma (RAMALHO, 2000) e pela Chlamydia, que foram consideradas microrganismos determinantes de poliartrites em caprinos (EAST, 1996).

Afora o diagnóstico diferencial por suas manifestações articulares na Artriteencefalite dos Caprinos e micoplasmoses, outras enfermidades também mereceram diferenciação clínica, como as listerioses, clamidiose e micoplasmose por suas sintomatologias nervosa (GEORGE, 1996). Além do mais, quando a Artrite-encefalite dos Caprinos evolui como forma clínica da pneumonia progressiva, foi, recomendado diferenciala da pneumonia causada por parasitoses pulmonares, por bactérias e abscessos pulmonares (EAST, 1996). 


\subsection{Levantamentos clínico-epidemiológicos da Artrite-encefalite dos Caprinos - Ocorrência e prevalência.}

A infecção e doença causadas pelo vírus da Artrite-encefalite dos Caprinos foram consideradas cosmopolitas, pois vários levantamentos soro-imunológicos e avaliações de casos clínicos demonstraram tanto a enfermidade como a infecção de caprinos pelo mencionado vírus, em várias regiões do mundo.

CRAWFORD e ADAMS (1981), utilizando a prova de imunodifusão em gel de ágar, realizaram o primeiro levantamento soro-imunológico para avaliar a ocorrência da infecção pelo vírus da Artrite-encefalite dos Caprinos, em 1160 amostras de soro sangüíneo, provenientes de 24 regiões dos Estados Unidos da América, verificando que $81 \%$ dos soros testados continham anticorpos antivírus da referida virose. A seguir, um dos pioneiros no estabelecimento da prevalência da infecção pelo vírus da Artrite-encefalite dos Caprinos, ADAMS et al. (1984), examinaram pelo teste de imunodifusão em gel de ágar, 3729 amostras de soro sangüíneo de caprinos, criados em 14 países localizados nos cinco continentes: América do Norte, Central e do Sul, Europa, Oceania e África. Na população avaliada, 33,9\% foram positivas, demonstrando a ocorrência da infecção pelo referido vírus; além do mais, destacaram que da amostragem avaliada e que apresentavam anticorpos antivírus da Artriteencefalite, 90,4\% eram originárias de países localizados na Europa e América do Norte. Nos demais paises estudados, $20 \%$ dos animais sororeagentes não eram autóctones, mas sim oriundos de importação e apenas $0,7 \%$ eram de caprinos nativos, que tiveram anterior contato e convivência com animais importados soropositivos. A partir desta observação, os autores suspeitaram que o vírus fosse originário da Europa, tendo se disseminado para os outros países através da exportação de caprinos. Após levantamentos clínico-epidemiológicos 
pioneiros dos anos de 1981/84, realizados no EUA e na Alemanha, inúmeros autores dedicaram-se à epidemiologia - ocorrência/prevalência da infecção dos caprinos pelo vírus da Artrite-encefalite em várias regiões do mundo.

Os mencionados resultados obtidos, utilizando a prova de imunodifusão em gel de ágar e o ensaio imunoenzimático (ELISA), foram sumarizados no Quadro 1 e 2, respectivamente, destacando os pesquisadores, ano da pesquisa, país de origem das amostras, a taxa de prevalência expressa em números relativos (\%) e o tamanho da população avaliada. Os resultados obtidos no Brasil foram apresentados em separado. 
QUADRO 1 - Distribuição das taxas de prevalência da infecção pelo vírus da Artriteencefalite dos Caprinos no Mundo, utilizando a prova de imunodifusão em gel de ágar, segundo o ano de avaliação, autor da pesquisa e o país de origem.

\begin{tabular}{|c|c|c|c|c|}
\hline ANO & AUTOR & PAÍS & $\begin{array}{c}\text { PREVALÊNCIA } \\
(\%)\end{array}$ & $\begin{array}{l}\text { POPULAÇÃO } \\
\text { EXAMINADA } \\
\end{array}$ \\
\hline 1981 & CRAWFORD e ADAMS & $\begin{array}{l}\text { ESTADOS UNIDOS DA } \\
\text { AMÉRICA }\end{array}$ & 81,0 & 1160 \\
\hline 1983 & STRAUB & ALEMANHA & 31,5 & 73 \\
\hline 1984 & ADAMS et al. & ÁFRICA DO SUL & 0,0 & 105 \\
\hline 1984 & ADAMS et al. & CANADÁ & 77,0 & 31 \\
\hline 1984 & ADAMS et al. & FIJI & 9,0 & 44 \\
\hline 1984 & ADAMS et al. & FRANÇA & 77,0 & 155 \\
\hline 1984 & ADAMS et al. & INGLATERRA & 9,5 & 200 \\
\hline 1984 & ADAMS et al. & MÉXICO & 5,8 & 380 \\
\hline 1984 & ADAMS et al. & NORUEGA & 74,0 & 19 \\
\hline 1984 & ADAMS et al. & NOVA ZELÂNDIA & 8,3 & 120 \\
\hline 1984 & ADAMS et al. & PERÚ & 9,6 & 198 \\
\hline 1984 & ADAMS et al. & QUÊNIA & 4,5 & 1045 \\
\hline 1984 & ADAMS et al. & SOMÁLIA & 0,0 & 103 \\
\hline 1984 & ADAMS et al. & SUDÃO & 0,0 & 98 \\
\hline 1984 & ADAMS et al. & SUÍÇA & 65,0 & 71 \\
\hline 1985 & CAPORALE et al. & ITÁLIA & 34,6 & 940 \\
\hline 1985 & DAWSON e WILESMITH & INGLATERRA & 4,3 & 2792 \\
\hline 1985 & NAZARA et al. & MÉXICO & 27,1 & 857 \\
\hline 1986 & AGRIMI et al. & ITÁLIA & 74,0 & 248 \\
\hline 1986 & HEIL & ALEMANHA & 8,3 & 1644 \\
\hline 1986 & GREWAL et al. & AUSTRÁLIA & 29,0 & 2708 \\
\hline 1986 & MACDIARMIND & NOVA ZELÂNDIA & 1,5 & 6551 \\
\hline 1986 & PALFI et al. & HUNGRIA & 75,0 & 800 \\
\hline 1986 & ADAIR & IRLANDA DO NORTE & 0,0 & 439 \\
\hline 1987 & EAST et al. & $\begin{array}{l}\text { ESTADOS UNIDOS DA } \\
\text { AMÉRICA }\end{array}$ & 53,0 & 2826 \\
\hline 1987 & GONZALES et al. & ESPANHA & 82,5 & 80 \\
\hline 1987 & HOUWERS & HOLANDA & 14,0 & 276 \\
\hline 1987 & PERRIN e POLACK & FRANÇA & 56,7 & 3063 \\
\hline 1987 & SURMAN et al. & AUSTRÁLIA & 0,1 & 4604 \\
\hline 1992 & CUTLIP et al. & $\begin{array}{l}\text { ESTADOS UNIDOS DA } \\
\text { AMÉRICA }\end{array}$ & 31,0 & 3790 \\
\hline 1993 & GRANT et al. & JAMAICA & 66,0 & 665 \\
\hline
\end{tabular}


QUADRO 2 - Distribuição das taxas de prevalência da infecção pelo vírus da Artriteencefalite dos Caprinos no Mundo, utilizando o ensaio imunoenzimático (ELISA), segundo o ano de avaliação, autor da pesquisa e o país de origem.

\begin{tabular}{|c|c|c|c|c|}
\hline ANO & AUTOR & PAÍS & $\begin{array}{c}\text { PREVALÊNCIA } \\
(\%)\end{array}$ & $\begin{array}{l}\text { POPULAÇÃO } \\
\text { EXAMINADA }\end{array}$ \\
\hline 1990 & SCHÖPF e SCHÖNBAUER & ÁUSTRIA & 12,3 & 390 \\
\hline 1990 & KRIEG e PETERHANS & SUÍÇA & 42,0 & 5974 \\
\hline 1991 & HÄNEL & ALEMANHA & 17,5 & 263 \\
\hline 1993 & BÉLANGER e LEBOEUF & CANADÁ & 82,5 & 2345 \\
\hline 1995 & GREENWOOD et al. & AUSTRÁLIA & 56,8 & 1484 \\
\hline
\end{tabular}

O primeiro relato sobre a ocorrência da Artrite-encefalite dos Caprinos, no Brasil, foi feita em 1986, no Rio Grande do Sul, quando MOOJEN et al. demonstraram a ocorrência da infecção pela detecção de anticorpos antivírus, utilizando a prova de imunodifusão em gel de ágar. Posteriormente, FITERMAN (1988) relatou a ocorrência da enfermidade na Bahia, em caprinos importados do Canadá, e GARCIA et al. (1992a) em São Paulo.

Em 1993, HÖTZEL et al., no Rio Grande do Sul, isolaram o vírus da Artriteencefalite dos Caprinos, em cultura celular de fragmentos da membrana sinovial de articulações de caprinos soropositivos, que apresentavam quadro clínico evidente de artrite.

Em outros Estados brasileiros, também foi demonstrada em caprinos autóctones, por vários pesquisadores e clínicos veterinários, a ocorrência da infecção pelo vírus da Artrite-encefalite: em São Paulo por D'ANGELINO et al. (1993) e FERNANDES (1997); em Minas Gerais, por ASSIS e GOUVEIA (1994); em Pernambuco, por SARAIVA NETO et al. (1995); no Rio de Janeiro, por CUNHA e NASCIMENTO (1995); na Bahia, por 
ASSIS e GOUVEIA (1994) e RAMALHO (2000) e no Ceará, por MELO e FRANKE (1997) e PINHEIRO et al. (2001). No Quadro 3 foram sumarizados os resultados encontrados por inúmeros autores que estudaram a freqüência e/ou prevalência da infecção ou formas clínicas da Artrite-encefalite dos Caprinos em vários Estados do Brasil, utilizando a prova de imunodifusão em gel de ágar, sendo destacados: o ano da realização da pesquisa, autores, Estado da Federação, taxa de prevalência ou freqüência/ocorrência - expressas em números relativos (\%) e tamanho da população utilizada na pesquisa. 
QUADRO 3 - Distribuição das taxas de prevalência da infecção pelo vírus da Artrite-encefalite dos Caprinos no Brasil, utilizando a prova de imunodifusão em gel de ágar, segundo o ano de avaliação, autor da pesquisa e o Estado da ocorrência.

\begin{tabular}{|c|c|c|c|c|}
\hline \multicolumn{5}{|c|}{ OCORRÊNCIA NO BRASIL } \\
\hline ANO & AUTOR & ESTADO & PREVALÊNCIA (\%) & POPULAÇÃO EXAMINADA \\
\hline 1986 & MOOJEN et al. & Rio Grande do Sul & 16,0 & 423 \\
\hline 1988 & FITTERMAN & Bahia & 52,2 & 23 \\
\hline 1993 & D'ANGELINO et al. & São Paulo & 37,5 & 837 \\
\hline 1994 & ASSIS e GOUVEIA & Bahia & 12,8 & 204 \\
\hline 1994 & ASSIS e GOUVEIA & Minas Gerais & 33,3 & 533 \\
\hline 1995 & $\begin{array}{l}\text { CUNHA e } \\
\text { NÄंSCIMENTO }\end{array}$ & Rio de Janeiro & 21,7 & 242 \\
\hline 1995 & SARAIVA NETO et al. & Pernambucọ & 17,6 & 397 \\
\hline 1996 & PINंHEIRO et al. & Piauí & 4,4 & 180 \\
\hline 1997 & MELO e FRANKE & Ceará & 40,7 & 242 \\
\hline 1997 & FERNANDES & São Paulo & 29,8 & 2065 \\
\hline 2000 & RAMALHO & Bahia & 29,2 & 692 \\
\hline 2001 & PINHEIRO et al. & Ceará & 1,0 & 4019 \\
\hline
\end{tabular}




\subsection{Fatores de variabilidade da taxa de prevalência da Artrite-encefalite dos Caprinos}

Com relação a ocorrência da Artrite-encefalite dos Caprinos nos rebanhos foram estudados vários fatores de variabilidade que poderiam influir na taxa de prevalência da infecção. Entre eles mereceram destaque, na bibliografia compulsada os seguintes: fatores etários; sexuais; raciais e sistema de criação, com suas variadas técnicas.

Vários pesquisadores verificaram que os resultados de seus trabalhos, demonstravam aumento da taxa de ocorrência de infecção pelo vírus da Artrite-encefalite dos Caprinos com o avançar da idade dos animais. Assim, CUTLIP et al. (1992) observaram que esses valores aumentavam cerca de $14 \%$ ao ano até os três anos de idade, para a seguir a prevalência manter-se estável, com valores ao redor de $45 \%$ de caprinos sororeagentes positivos aos antígenos do vírus responsável pela Artrite-encefalite. Estas observações confirmaram afirmações anteriores feitas por EAST et al. (1987) e PERRIN e POLACK (1987). Mas discordaram tanto das conclusões apresentadas anteriormente, por DAWSON e WILLESMITH (1985), que observaram maior número de caprinos de um ano de idade (40,0\%) reagentes ao vírus da AEC e diminuição desses valores $(26,8 \%)$ entre os animais de dois anos de idade, como também dos resultados referidos por GREWAL et al. (1986), que não demonstraram diferença estatisticamente significante entre resultados obtidos de animais de diferentes faixas etárias.

No Brasil, vários especialistas em Clínica de Ruminantes procuraram estabelecer a influência da idade sobre os valores da taxa de prevalência da Artrite-encefalite dos Caprinos. De forma pioneira SARAIVA NETO et al. (1995), demonstraram que os animais com mais de 54 meses de idade apresentavam maior taxa de prevalência da enfermidade. Outros pesquisadores confirmaram essas observações. Assim: FERNANDES (1997), relatou aumento da prevalência da infecção com o desenvolvimento etário, sendo a taxa determinada estatisticamente maior nos animais com mais de 24 meses de idade; MELO e FRANKE (1997) não observaram diferenças estatisticamente significantes entre os animais de diferentes faixas etárias estudadas e a presença da infecção pelo vírus da Artrite- 
encefalite dos Caprinos; segundo BOHLAND (1998), a taxa de prevalência da infecção por esse vírus aumentou significativamente após os 6 meses de idade, mantendo valores constantes entre 6 e 48 meses e atingindo os valores máximos após os 48 meses de idade; e RAMALHO (2000), verificou que a prevalência dessa infecção em caprinos com até seis meses de idade era significativamente menor (16,9\%) do que a observada nos animais com mais de 6 meses de vida (variação entre 26,8 e 34,4\%). Todavia tais afirmações discordaram das referidas por MELO e FRANKE (1997), que não observaram diferença estatisticamente significante entre resultados de prevalência da infecção pelo vírus da AEC em caprinos de diferentes faixas etárias.

Há muitos anos os pesquisadores se preocuparam em determinar a dependência da susceptibilidade dos animais domésticos à ação dos agentes etiológicos, na dependência de fatores raciais relacionados a esses animais. Tanto isso era verdade, que no caso da Artrite-encefalite dos Caprinos NAZARA et al. (1985) concluíram, ao avaliarem os resultados de levantamento epidemiológico realizado em população de 857 caprinos criados no México, que os animais Criolos, não apresentavam anticorpos séricos que revelassem infecção pelo vírus causador dessa enfermidade. Mas a preocupação de se avaliar a influência dos fatores raciais sobre as taxas de prevalência da infecção de caprinos pelo vírus causador da Artrite-encefalite figurou na primeira pesquisa sobre a epidemiologia da enfermidade conduzida por CRAWFORD e ADAMS (1981). Esses pesquisadores não detectaram diferenças estatisticamente significativas entre as prevalências determinadas em caprinos de sete diferentes raças: Alpina; Angorá; La Mancha; Nubiana; Pygmy; Saanen; Toggenbourg; e seus mestiços. Tais resultados viriam a ser, posteriormente, confirmados por EAST et al. (1987). Apesar das considerações retromencionadas na literatura especializada encontraram-se afirmações que destacam a maior prevalência da Artrite-encefalite dos Caprinos em determinadas raças, em condições específicas de criação. NAZARA et al. (1985) demonstraram em caprinos leiteiros prevalência igual a $27,1 \%$, ao passo que animais nativos da raça "Criolla" não demonstravam sinais da ocorrência dessa virose. Esses resultados foram confirmados na Austrália, por GREWAL et al. (1986) ao demonstrarem maior freqüência da infecção pelo vírus da Artrite-encefalite dos Caprinos 
em animais de raça leiteira (Alpina Inglesa, Nubiana, Saanen, Toggenbourg e seus mestiços) do que nas raças de caprinos especializados para a produção de fibras (Angorá e Cashemere). No Brasil, os pesquisadores que se dedicaram ao estudo da avaliação dos fatores com potencial de influírem nas taxas de prevalência da Artrite-encefalite nos rebanhos caprinos das várias regiões geo-econômicas do País e, em suas pesquisas apresentaram delineamentos experimentais que permitissem conclusões com maior potencial de elucidação das dúvidas de teor clínico-epidemiológico ainda existentes.

SARAIVA NETO et al. (1995) demonstraram que a prevalência da Artrite-encefalite dos Caprinos, no Estado de Pernambuco, era maior nos caprinos puros de raças de origem européia (Saanen, Toggenbourg e Alpina), sendo a taxa estimada para esses animais, igual a 21,1\%, significativamente, maior do que a encontrada em animais Mestiços $(9,8 \%)$. Entre os caprinos puros de origem africana, como Anglo Nubiana e Mambrina, não foi verificado nenhum animal soropositivo, o que poderia reforçar a hipótese, que a Artrite-encefalite dos Caprinos foi introduzida no país pela importação indiscriminada de animais de origem européia.

No Estado de São Paulo, as observações de FERNANDES (1997) se contrapuseram às de SARAIVA et al. (1995) ao estudar caprinos das raças Saanen, Alpina, Toggenbourg, Anglo Nubiana e Mestiças, pois verificou que a maior taxa de prevalência da Artrite-encefalite dos Caprinos foi determinada na raça Anglo Nubiana, criada em sistema intensivo para produção de leite, com 51\% de caprinos soropositivos ao vírus. Ainda em São Paulo, BOHLAND (1998), trabalhando com caprinos das raças Saanen e Alpina, não encontrou diferença estatisticamente significante entre as taxas de prevalência para elas determinadas.

No Estado da Bahia, RAMALHO (2000) demonstrou que a taxa de prevalência da Artrite-encefalite dos Caprinos foi significativamente maior nos caprinos das raças Alpina (53,7\%) e Saanen $(33,5 \%)$ do que nas demais raças estudadas, Anglo Nubiana, Toggenbourg, Mambrina e Mestiça. Ressaltou, todavia, a mencionada pesquisadora que os sistemas de criação eram diferentes, este último grupo de animais (Anglo Nubiana e Mestiça) estavam em regime de criação semiextensivo e aqueles especializados na produção leiteira (Alpina e Saanen) submetiam-se à regime 
intensivo de criação.

A influência do fator sexual sobre a freqüência da Artrite-encefalite dos Caprinos aparentemente estaria relacionada aos diferentes sistemas de criação a que tem sido, tradicionalmente, submetidos os machos e as fêmeas dessa espécie animal (Capra hircus) e não a fatores intrínsecos relacionados ao sexo. Algumas pesquisas demonstraram que as taxas de prevalência dessa infecção viral dos caprinos eram semelhantes para animais do sexo feminino e masculino (EAST et al., 1987; CUTLIP et al., 1992; SARAIVA NETO et al., 1995; FERNANDES, 1997; MELO e FRANKE, 1997; RAMALHO, 2000). Todavia, BOHLAND (1998) verificou um maior número de soropositivos para o vírus da Artrite-encefalite dos Caprinos entre os caprinos do sexo feminino. Mas outros pesquisadores afirmaram que maior taxa de prevalência verificada para um dos sexos dos caprinos seria fortemente influenciada por outros fatores não relacionados ao sexo propriamente dito, sendo fortemente dependentes do sistema de criação ao qual se submetiam esses animais (CRAWFORD e ADAMS, 1981; GREWAL et al., 1986).

No Estado do Ceará, MELO e FRANKE (1997) encontraram uma relação direta entre o sistema de manejo intensivo de criação e o grande número de animais sororeagentes à infecção pelo vírus da Artrite-encefalite dos Caprinos, sugerindo que essa ocorrência poderia, facilmente, ser explicada pelo permanente confinamento dos animais, em estreito contato corporal e pela amamentação coletiva dos cabritos: duas condições que favorecem a disseminação do vírus no rebanho. Essas afirmações foram confirmadas por RAMALHO (2000), ao relatar, em sua Tese de Doutoramento, submetida à FMVZ-USP, que a taxa de prevalência da Artrite-encefalite dos Caprinos, em animais criados no Estado da Bahia em regime semi-extensivo (35,4\%) de criação foi significativamente maior do que nos caprinos criados em sistema extensivo $(1,2 \%)$, típico para animais produtores de carne. Além do mais, demonstrou que no sistema intensivo de criação, sob supervisão eficiente de Clínicos Veterinários, orientada para a preservação da saúde animal a taxa de prevalência não atingia valores desesperadores, pois na população avaliada essa taxa equivalia a $9,6 \%$ de caprinos sororeagentes aos antígenos do vírus da Artrite-encefalite dos Caprinos. 


\subsection{Avaliação da Artrite-encefalite dos Caprinos - prognóstico e tratamentos: sintomático e profilático.}

Não existe tratamento para a Artrite-encefalite dos Caprinos, sendo o prognóstico reservado, pois como já foi mencionado, anteriormente, considerou-se variável o agravamento da enfermidade durante sua evolução. Em certas circunstâncias, o caprino infectado pelo agente etiológico da doença não manifesta nenhum sintoma, durante um longo período de tempo, enquanto que em outros animais a artrite e a perda de peso poderiam ser descritas como graves e progressivas. $\mathrm{O}$ estresse parece acelerar o desenvolvimento clínico da Artrite-encefalite dos Caprinos. A forma clínica nervosa da doença, ou seja, a encefalomielite nos cabritos, ocasionalmente, ocorreria em animais adultos, sendo, então, o prognóstico mau, pois na maioria das vezes os caprinos afetados seriam sacrificados, por questões humanitárias (EAST, 1996).

Os tratamentos, visando a cura dos caprinos enfermos, de acordo com as informações de AL-ANI e VESTWEBER (1984) foram realizados sem sucesso e somente vislumbravam as possibilidades da terapia sintomática, atenuando algumas manifestações clínicas que acompanhavam a evolução da infecção. No acompanhamento da enfermidade de algumas cabras poderiam ser recomendados antibióticos de amplo espectro para se evitar as complicações por infecções bacterianas secundárias. Manifestações sintomáticas da forma clínica articular dessa doença tem sido amenizada pelo aparo adequado dos cascos dos caprinos acometidos por artrite e os colocando em estábulos com camas macias e mais altas, associando nos casos mais graves, quando a dor for intensa, drogas antiinflamatórias (AL-ANI e VESTWEBER, 1984).

Nos criatórios de caprinos a prática da hiperimunização de cabras com preparações de vírus vivo atenuado ou inativado não protegeram os animais contra infecções subseqüentes, em desafios com o vírus vivo da Artrite-encefalite dos Caprinos (NARAYAN e CORK, 1990). 
As recomendações e medidas efetivas de controle da infecção deveriam ser implantadas nos criatórios, pois a identificação dos caprinos infectados pelo vírus da Artrite-encefalite dos Caprinos por métodos soro-imunológicos e a eliminação desses animais do rebanho foram consideradas medidas importantes no controle da enfermidade, mas insuficientes (NARAYAN e CORK, 1990).

Assim sendo, recomendou-se associarem-se ao processo de controle e erradicação da infecção um sistema de prevenção da transmissão do vírus da Artrite-encefalite dos Caprinos pela ingestão de leite de cabras infectadas, controle dos meios iatrogênicos de transmissão da infecção, associado ao isolamento dos animais soronegativos e monitoramento imuno-sorológico dos rebanhos (EAST, 1996). As medidas mais radicais de controle da Artrite-encefalite dos Caprinos recomendaram a eliminação de todos os caprinos do rebanho onde houver animais soropositivos e suas substituições por outros soronegativos, para a erradicação definitiva da doença. Porém tal método demonstrou-se impraticável em inúmeras criações de vários países aonde foram implementados. Atualmente existem métodos menos drásticos, mais econômicos e factíveis para o controle da Artrite-encefalite dos Caprinos (PÉTURSSON et al., 1992). Todavia, jamais dever-se-ía esquecer recomendações anteriormente ressaltadas, afirmando que devido às características físicas e ao ciclo biológico do agente etiológico desta virose, o contato direto entre companheiros de aprisco e/ou a ingestão de leite contaminado pelo vírus seriam os fatores mais importantes na disseminação do vírus (NARAYAN e CORK, 1990).

Trabalhos recentes, visando esclarecer inúmeros aspectos clínico-epidemiológicos da Artrite-encefalite dos Caprinos, relataram que a erradicação desta enfermidade de um plantel deveria ser considerada um objetivo difícil de ser alcançado, entretanto, a prevalência da infecção poderia mais facilmente ser reduzida. Para tanto, recomendou-se que os cabritos fossem retirados do convívio 
materno imediatamente após o nascimento, o que requer final da gestação e parto assistidos por um funcionário e/ou acompanhamento clínico veterinário constantes; a esses cabritos deveria ser administrado colostro e leite de cabras soronegativas, colostro e leite de vaca, ou colostro e leite pasteurizado de cabras soropositivas (EAST, 1996). Ressaltou, ainda, EAST (1996) que alimentar os cabritos com colostro pasteurizado de cabras sororeagentes positivas, resultava no aparecimento de jovens animais soropositivos aos antígenos de vírus da Artrite-encefalite dos Caprinos, como resultado da transmissão passiva de anticorpos pela ingestão do colostro; todavia esses anticorpos desapareceriam do plasma sangüíneo, entre 8 e 16 semanas de vida.

Testes imuno-sorológicos periódicos dos caprinos foram recomendados, há muito tempo, como necessários para detectar e favorecer a remoção dos animais soropositivos aos antígenos do vírus da Artrite-encefalite dos Caprinos do rebanho. Além do mais, o manejo do plantel e sua taxa de prevalência de infecção foram considerados fatores preponderantes para a rotina da realização desses testes e também para estabelecer a taxa de descarte dos animais; esse seria um processo lento porém o mais eficaz por seus resultados quando a prevalência da enfermidade for pequena (PÉTURSSON et al., 1992). Se, no processo de controle ou erradicação da Artrite-encefalite dos Caprinos de determinado criatório houve opção para a separação dos animais em dois rebanhos, um com caprinos infectados e outro com animais sadios, esses grupos de caprinos deveriam permanecer apartados, no mínimo, por dois metros de distância, não permitindo o compartilhamento da alimentação e da água. Como foi levantada a suspeita da possível disseminação do vírus causador dessa infecção pelo uso comum de agulhas de injeção e/ou de sutura, de materiais cirúrgicos contaminados por sangue. Mesmo essas vias iatrogênicas de transmissão não terem sido experimentalmente esclarecidas, tem sido recomendada a restrição e cuidados na utilização desses 
equipamentos (BULGIN, 1990). A obediência das mencionadas recomendações e a manutenção de rebanhos fechados, com monitoramento imuno-sorológico, em intervalos regulares, foram considerados métodos excelentes para se manter a infecção fora do rebanho (NARAYAN e CORK, 1990).

A repetição rotineira dos testes imuno-sorológicos, com intervalo de 6 meses foi uma recomendação feita por AL-ANI e VESTWEBER (1984), para identificar os indivíduos infectados pelo vírus da Artrite-encefalite dos Caprinos, devendo eles serem removidos do rebanho, para diminuir a ocorrência da infecção no plantel. Ressaltaram, ainda, os referidos pesquisadores que dois testes de imunodifusão negativos, em exames realizados com intervalo de 6 meses significaria que ele estaria livre da infecção. Os sistemas de criação e o método utilizado para a eliminação da infecção pelo já mencionado vírus de plantéis infectados, em quaisquer situação, foi considerada muito difícil e demorada, além de dispendiosa. Por isso, foi destacada uma posição de suma importância como medida preventiva, para manterem-se plantéis livres da Artrite-encefalite dos Caprinos: optar nessas circunstâncias pela introdução, no plantel apenas matrizes e reprodutores soronegativos aos antígenos desse vírus. 


\subsection{Impacto econômico da Artrite-encefalite dos Caprinos sobre a produção}

\section{dos caprinos.}

O impacto econômico causado pela infecção do vírus da Artrite- encefalite dos Caprinos foi estudado por vários autores, avaliando o significado dessa enfermidade sobre a produção da caprinocultura e sobre alguns índices de produtividade: produção de leite; índices de fertilidade e na taxa de descarte de caprinos do plantel.

Na Alemanha, VON MOCKENHAUPT e BAUER (1987) apresentaram resultados pioneiros de pesquisa que avaliou alguns índices de produção de cabras sororeagentes ao vírus da Artrite-encefalite dos Caprinos, demonstrando que elas apresentavam maior número de problemas de reprodução, com redução do índice de fertilidade por falhas na fecundação e maior intervalo interpartos, além do mais, essas cabras apresentavam menor produção de leite, do que os animais soronegativos.

Ao avaliar, na Austrália, a duração média da lactação de cabras, GREENWOOD (1995), verificou que os animais com reação sorológica positiva ao vírus da Artrite-encefalite dos Caprinos apresentavam menor período de lactação do que as das cabras soronegativas, observando a significativa diferença de 21 dias, além do mais, demonstrou-se nessa pesquisa a menor produção de leite dessas cabras.

Segundo BOHLAND (1998), a duração média da lactação de cabras sororeagentes aos antígenos do vírus da Artrite-encefalite dos Caprinos (223,4 dias) foi significativamente menor do que a dos caprinos não reagentes aos mencionados antígenos (272,6 dias). A média de produção leiteira diária $(\mathrm{kg} / \mathrm{dia})$ também foi menor nas cabras jovens reagentes, no teste de imunodifusão em gel de ágar para AEC, sendo as diferenças significativas nos animais com idade variando de 12 a 24 meses 
de idade $(1,2 \pm 0,4 \mathrm{~kg} /$ dia e $1,5 \pm 0,5 \mathrm{~kg} /$ dia, respectivamente, para cabras sororeagentes positivas e sororeagentes negativas) e nos caprinos mais velhos, com mais de 48 meses de idade $(1,6 \pm 0,7 \mathrm{~kg} / \mathrm{dia}$ e $2,1 \pm 0,8 \mathrm{~kg} /$ dia, respectivamente, caprinos reagentes e não reagentes ao referido vírus). Ainda, para a pesquisadora retromencionada o percentual de descarte dos caprinos sororeagentes ao vírus da Artrite-encefalite dos Caprinos (30,5\%) foi, significativamente, maior do que o observado em animais não reagentes (22,9\%). Os resultados apresentados por BOHLAND (1998) confirmaram o que fora, anteriormente, descrito por outros pesquisadores, que afirmaram que cabras com sorologia positiva ao vírus causador da Artrite-encefalite apresentavam menor produção de leite (SMITH eCUTLIP, 1988; KRIEG e PETERHANS, 1990); além do mais, elas apresentavam menores teores lácteos de gordura do que as negativas. Na oportunidade, KRIEG e PETERHANS (1990), na Suíça, reportaram redução de $10 \%$ na produção de leite em cabras infectadas pelo já mencionado vírus, como também destacaram em sua pesquisa o efeito econômico gravoso para a exportação de caprinos para o exterior face à grande taxa de prevalência da enfermidade no país.

\subsection{Determinação dos teores protéicos e da atividade da enzima gamaglutamiltransferase \\ - GT do soro sangüíneo de cabritos para avaliação da transferência de imunidade passiva para neonatos por ingestão do colostro.}

As proteínas sempre foram consideradas constituintes essenciais de todas as células do organismo e corresponderiam a cerca de $18 \%$ do peso corporal dos animais (SWENSON, 1996). Constituem um grupo de moléculas heterogêneas com várias características e funções. Às proteínas plasmáticas foram atribuídas as seguintes funções essenciais: 1. participação na manutenção da pressão sangüínea normal, por contribuírem no grau de viscosidade sangüínea; 2. influenciar a 
estabilidade da suspensão de eritrócitos; 3. participação na regularização do equilíbrio ácido-básico do sangue; 4. afetar a solubilidade de açúcares, lipídeos e outras substâncias em solução no plasma e, 5. transportar substâncias, como nutrientes (cálcio, fósforo, ferro, cobre, lipídeos, vitaminas lipossolúveis e aminoácidos), hormônios (tireoxina, esteróides), colesterol, bilirrubina e enzimas (SWENSON, 1996).

Segundo SWENSON (1996), a gamaglobulina, elaborada pelos linfócitos e células plasmáticas, nos tecidos de vários órgãos, conteria inúmeros anticorpos produzidos pelo estímulo de vários antígenos, formaria uma fração denominada genericamente de imunoglobulinas. $\mathrm{Na}$ maioria dos animais recém-nascidos, com exceção dos primatas e roedores, o soro sangüíneo apresenta pequena concentração da fração protéica gamaglobulina, chegando, em alguns animais, a estar ausente do sangue, pois a placenta, nessas espécies, foi considerada impermeável à moléculas das imunoglobulinas e o feto não estaria capacitado a sintetizá-las em profusão.

A literatura nacional e internacional dedicada ao tema pôde ser considerada escassa particularmente no período neonatal, de caprinos e, referindo-se a transferência passiva da fração gamaglobulina pela ingestão do colostro. Em trabalho pioneiro realizado no Brasil afim de estudar-se o quadro protéico do soro sangüíneo de animais da espécie caprina, BIRGEL et al. (1968) analisaram 150 amostras de soro oriundas de fêmeas caprinas, de diferentes idades, das raças Anglo Nubiana, Toggenbourg e Angorá. Nessa pesquisa os autores verificaram os níveis séricos de proteína total, albumina, globulinas, gamaglobulina e a relação albumina/globulina. Dando seqüência ao estudo dos teores protéicos do sangue de caprinos, BIRGEL (1969), pesquisou as variações desses teores durante o desenvolvimento etário dos animais, demonstrando que o teor sérico de proteína total aumenta gradativamente com a idade. $\mathrm{O}$ mencionado pesquisador concluiu que esse fato era conseqüente ao aumento da fração gamaglobulina, o que ocorreria após a ingestão do colostro. 
Ainda no Brasil, FERRI et al. (1970) e BIRGEL et al. (1971), estudaram a influência da idade sobre os teores séricos das frações albumina e globulinas de fêmeas da espécie caprina das raças Toggenbourg e Anglo Nubiana, fazendo o fracionamento protéico pela técnica da eletroforese. Nas duas pesquisas os retromencionados autores observaram que somente os teores séricos da fração gamaglobulina era influenciada pelo desenvolvimento etário dos caprinos, demonstrando gradativo e significativo aumento do teor dessa fração protéica com o evoluir da idade.

As afirmações pioneiras dos autores retromencionados, foram confirmadas no Brasil, por BARIONI et al. (2001), que estudando 30 fêmeas da espécie caprina da raça Alpina, divididas em três grupos etários, determinaram os valores séricos médios dos teores de proteína total, albumina, globulina e relação albumina/globulina. Os mencionados pesquisadores demonstraram que o teor de proteína total aumentava com o desenvolvimento etário, tal aumento devia-se a significativo aumento da fração globulina, pois demonstraram diminuição do teor de albumina.

Para facilitar a visualização dos resultados do proteinograma do soro sangüíneo de caprinos, referidos na literatura, considerando as variações de suas frações no desenvolvimento etário dos caprinos, foram apresentados, a seguir na tabela 1.

A gamaglutamiltransferase $(\gamma \mathrm{GT})$ foi considerada uma enzima envolvida no metabolismo da glutationa e na transferência dos grupos glutamil. Com exceção do tecido muscular, em todas outras células do organismo animal foi demonstrada a atividade da enzima $\gamma \mathrm{GT}$. O aumento da atividade sérica da $\gamma \mathrm{GT}$ estaria relacionado, principalmente com alterações hepáticas. Mas, segundo THOMPSON e PAULI (1981), demonstrou-se grande atividade da $\gamma$ GT em efusões orgânicas como o fluido seminal, bile, colostro e leite. De fato, estudo realizado com colostro de bovinos, revelou que a atividade da gamaglutamiltransferase era significativamente maior no colostro do que no leite - 2,5 a 3,3 vezes maior e cerca de 300 vezes maior do que a atividade demonstrada no soro 
sangüíneo. FEITOSA (1998) comprovou, categoricamente que a atividade enzimática da $\gamma$ GT do soro sangüíneo de bezerros era mínima no momento do nascimento, aumentando abrupta e significativamente 12 horas após a ingestão do colostro e a partir desse momento, a atividade dessa enzima diminuiu de forma gradativa atingindo, aos 60 dias de idade, valores equivalentes aos descritos para bovinos adultos. Do mesmo modo LEAL (2001) demonstrou que a atividade sérica da gamaglutamiltransferase atingiu os valores máximos em bezerras com idades variando entre 16 e 24 horas de vida; a seguir relatou a ocorrência de uma diminuição da atividade enzimática e a partir do $11^{\mathrm{O}}$. dia de idade, os valores da atividade da $\gamma \mathrm{GT}$ eram similares aos apresentados por bovinos adultos. 
Tabela 1 - Valores do proteinograma (g/dl) sérico de caprinos, descritos na literatura compilada, dando-se destaque aos autores e características dos animais. Valores apresentados em termos de média e desvio padrão ( $\mathrm{X} \pm \mathrm{s}$ ).

\begin{tabular}{|c|c|c|c|c|c|c|c|c|}
\hline \multirow[b]{2}{*}{ AUTORES } & \multirow[b]{2}{*}{ OBSERVAÇÕES } & \multirow{2}{*}{$\begin{array}{l}\text { Proteína } \\
\text { Total } \\
\text { G/dl }\end{array}$} & \multirow[b]{2}{*}{$\begin{array}{c}\text { A.lbumina } \\
\text { g/dl }\end{array}$} & \multirow{2}{*}{$\begin{array}{c}\text { Globulina } \\
\text { Total } \\
\text { g/dl }\end{array}$} & \multicolumn{3}{|c|}{ Fracionamento de globulinas } & \multirow[b]{2}{*}{ RelaçãoA:G } \\
\hline & & & & & $\begin{array}{c}\text { Älfaglobulina } \\
\text { g/dl }\end{array}$ & \begin{tabular}{c}
\multicolumn{2}{c}{ Betaglobulina } \\
g/dl
\end{tabular} & $\begin{array}{c}\text { Gamaglobúlina } \\
\text { g/dl }\end{array}$ & \\
\hline $\begin{array}{l}\text { BIRGEL et al. } \\
\text { (1968) }\end{array}$ & 150 cabras & $6,44 \pm 0,07$ & $2,37 \pm 0,04$ & $4,07 \pm 0,09$ & & . & $1,54 \pm 0,04$ & $0,66 \pm 0,03$ \\
\hline \multirow{6}{*}{$\begin{array}{l}\text { BIRGEL et al } \\
(1969)\end{array}$} & 150 cabras & & & & & & & \\
\hline & $-<6$ meses & $5,78 \pm 0,09$ & $2,49 \pm 0,09$ & $3,29 \pm 0,16$ & & & $1,24 \pm 0,08$ & $0,86 \pm 0,08$ \\
\hline & -7 a 12 meses & $6,12 \pm 0,13$ & $2,37 \pm 0,09$ & $3,76 \pm 0,15$ & & & $1,45 \pm 0,07$ & $0,68 \pm 0,05$ \\
\hline & -13 a 24 meses & $6,57 \pm 0,12$ & $2,38 \pm 0,10$ & $4,19 \pm 0,17$ & & & $1,57 \pm 0,06$ & $0,63 \pm 0,06$ \\
\hline & -25 a 48 meses & $6,80 \pm 0,16$ & $2,38 \pm 0,09$ & $4,45 \pm 0,21$ & & & $1,64 \pm 0,07$ & $0,59 \pm 0,05$ \\
\hline & $->48$ meses & $6,91 \pm 0,14$ & $2,26 \pm 0,11$ & $4,66 \pm 0,22$ & & & $1,81 \pm 0,07$ & $0,55 \pm 0,05$ \\
\hline \multirow{6}{*}{$\begin{array}{l}\text { FERRI et al. } \\
(1970)\end{array}$} & 30 cabras Toggenbourg & & & & & & & \\
\hline & $-<6$ meses & 5,82 & $2,15 \pm 0,08$ & & $0,57 \pm 0,02$ & $0,74 \pm 0,03$ & $2,36 \pm 0,07$ & \\
\hline & -7 a 12 meses & 6,12 & $1,95 \pm 0,04$ & & $0,63 \pm 0,06$ & $0,61 \pm 0,30$ & $2,92 \pm 0,10$ & \\
\hline & -13 a 24 meses & 6,43 & $1,86 \pm 0,08$ & & $0,52 \pm 0,04$ & $0,77 \pm 0,03$ & $3,28 \pm 0,18$ & \\
\hline & -25 a 48 meses & 7,67 & $2,07 \pm 0,02$ & & $0,63 \pm 0,02$ & $0,57 \pm 0,02$ & $4,39 \pm 0,15$ & \\
\hline & ->48 meses & 7,33 & $1,94 \pm 0,05$ & & $0,51 \pm 0,02$ & $0,68 \pm 0,04$ & $4,20 \pm 0,03$ & \\
\hline \multirow{5}{*}{$\begin{array}{l}\text { BIRGEL et al } \\
(1971)\end{array}$} & .30 cabras Anglo Nubiana & & & & & & & \\
\hline & -6 meses & 6,16 & $2,33 \pm 0,02$ & & $0,60 \pm 0,02$ & $0,85 \pm 0,03$ & $2,38 \pm 0,07$ & \\
\hline & $\begin{array}{l}-7 \text { a } 12 \text { meses } \\
-13 \text { a } 24 \text { meses }\end{array}$ & $\begin{array}{l}6,00 \\
6,76\end{array}$ & $\begin{array}{l}2,10 \pm 0,04 \\
2,35 \pm 0,04\end{array}$ & & $\begin{array}{l}0,55 \pm 0,01 \\
0.68 \pm 0.01\end{array}$ & $\begin{array}{l}0,79 \pm 0,02 \\
0,75 \pm 0.02\end{array}$ & $\begin{array}{l}2,56 \pm 0,06 \\
2,98 \pm 0,13\end{array}$ & \\
\hline & -25 a 48 meses & 6,88 & $2,10 \pm 0,05$ & & $0,92 \pm 0,01$ & $0,84 \pm 0,01$ & $3,02 \pm 0,06$ & \\
\hline & $->48$ meses & 6,91 & $2,12 \pm 0,03$ & & $0,68 \pm 0,01$ & $0,69 \pm 0,02$ & $3,42 \pm 0,11$ & \\
\hline
\end{tabular}

(continua) 
Tabela 1 - Valores do proteinograma (g/dl) sérico de caprinos, descritos na literatura compilada, dando-se destaque aos autores e características dos animais. Valores apresentados em termos de média e desvio padrão $(\mathrm{X} \pm \mathrm{s}$ ).

\begin{tabular}{|c|c|c|c|c|c|c|c|c|}
\hline \multirow[b]{2}{*}{ AUTORES } & \multirow[b]{2}{*}{$\begin{array}{c}\text { OBSERVAÇÕES } \\
\cdot\end{array}$} & \multirow{2}{*}{$\begin{array}{c}\text { Proteína } \\
\text { Total } \\
\text { G/dl } \\
\end{array}$} & \multirow[b]{2}{*}{$\begin{array}{l}\text { Albumina } \\
\text { g/dl }\end{array}$} & \multirow{2}{*}{$\begin{array}{l}\text { Globulina } \\
\text { Total } \\
\text { g/dl }\end{array}$} & \multicolumn{3}{|c|}{ Fracionamento de globulinas } & \multirow[b]{2}{*}{ RelaçãoA:G } \\
\hline & & & & & $\begin{array}{c}\text { Alfaglobulina } \\
\cdot \mathrm{g} / \mathrm{dl}\end{array}$ & $\begin{array}{l}\text { Betaglobulina } \\
\cdot \quad \mathbf{g} / \mathbf{d l}\end{array}$ & $\begin{array}{c}\text { Gamaglobulina } \\
\text { g/dl }\end{array}$ & \\
\hline $\begin{array}{l}\text { CASTRO et al. } \\
\text { (1977) }\end{array}$ & $\begin{array}{l}.34 \text { cabras Pygmy } \\
-12 \text { meses } \\
-12 \text { a } 24 \text { meses } \\
-24 \text { a } 36 \text { meses }\end{array}$ & $\begin{array}{l}6,7 \pm 0,5 \\
7,4 \pm 0,5 \\
7,5 \pm 0,5\end{array}$ & $\begin{array}{l}3,6 \pm 0,4 \\
3,2 \pm 0,5 \\
2,8 \pm 0,3\end{array}$ & $\begin{array}{l}3,3 \pm 0,2 \\
4,6 \pm 1,1 \\
4,6 \pm 0,4\end{array}$ & $\begin{array}{l}0,75 \pm 0,1 \\
0,95 \pm 0,3 \\
0,85 \pm 0,1\end{array}$ & $\begin{array}{l}0,5 \pm 0,1 \\
0,4 \pm 0,1 \\
0,7 \pm 0,1\end{array}$ & $\begin{array}{l}1,1 \pm 0,7 \\
1,8 \pm 0,7 \\
2,3 \pm 0,4\end{array}$ & $\begin{array}{l}1,2 \pm 0,4 \\
0,8 \pm 0,2 \\
0,6 \pm 0,1\end{array}$ \\
\hline $\begin{array}{l}\text { BEHERA et al. } \\
\text { (1993) }\end{array}$ & $\begin{array}{l}192 \text { caprinos } \\
20 \text { caprinos de } 3 \text { meses } \\
-27 \text { caprinos de } 6 \text { meses } \\
-26 \text { animais de } 9 \text { meses } \\
-26 \text { animais de } 12 \text { meses } \\
-34 \text { animais acima de } 24 \text { meses }\end{array}$ & $\begin{array}{l}6,01 \pm 0,20 \\
7,14 \pm 0,19 \\
7,02 \pm 0,17 \\
7,35 \pm 0,16 \\
7,34 \pm 0,15\end{array}$ & $\begin{array}{l}2,52 \pm 0,07 \\
3,99 \pm 0,18 \\
4,05 \pm 0,12 \\
4,42 \pm 0,18 \\
4,49 \pm 0,21\end{array}$ & $\begin{array}{l}3,49 \pm 0,15 \\
3,15 \pm 0,13 \\
2,97 \pm 0,14 \\
2,93 \pm 0,13 \\
2,86 \pm 0,18\end{array}$ & & & & $\begin{array}{l}0,72 \\
1,27 \\
1,37 \\
1,51 \\
1,57\end{array}$ \\
\hline $\begin{array}{l}\text { BARIONI et al. } \\
(2001)\end{array}$ & $\begin{array}{l}30 \text { cabras Alpina } \\
10 \text { fêmeas de } 4 \text { meses } \\
10 \text { fêmeas de } 18 \text { meses } \\
10 \text { fêmeas de } 24 \text { a } 60 \text { meses }\end{array}$ & $\begin{array}{l}6,29 \pm 0,94 \\
7,27 \pm 0,73 \\
7,14 \pm 0,84\end{array}$ & $\begin{array}{l}3,51 \pm 0,41 \\
4,92 \pm 1,06 \\
3,70 \pm 0,20\end{array}$ & $\begin{array}{l}2,78 \pm 0,95 \\
3,06 \pm 0,56 \\
3,44 \pm 0,79\end{array}$ & & & & $\begin{array}{l}1,40 \pm 0,48 \\
1,43 \pm 0,44 \\
1,14 \pm 0,30\end{array}$ \\
\hline
\end{tabular}




\section{MATERIAL E MÉTODOS}

\subsection{Considerações Gerais}

O estudo clínico-epidemiológico para avaliação da Artrite-encefalite dos Caprinos, delineado para esta tese, foi desenvolvido com 820 animais, criados e antidos em14 propriedades produtoras de caprinos leiteiros, afiliadas à CAPRIPAULO - Associação Paulista de Criadores de Caprinos, localizadas em 13 municípios do Estado de SãoPaulo, que concordaram em participar de projeto de controle e/ou erradicação dessa enfermidade viral. Esse projeto envolveu a já mencionada Associação e alguns selecionados riadores, sob a coordenação do Centro de Pesquisa e Diagnóstico de Enfermidades de Ruminantes - CPDER do Departamento de Clínica Médica da Faculdade de Medicina Veterinária da Universidade de São Paulo com a finalidade de determinar a prevalência e incidência da infecção pelo vírus da Artrite-encefalite dos Caprinos. Para serem alcançados os bjetivos do projeto foram colhidas, em quatro oportunidades, 3.280 amostras de sangue de caprinos, cujo soro, após adequada separação, era estocado em congelador em temperatura de $-70^{\circ} \mathrm{C}$ até o momento da realização das provas imuno-sorológicas e bioquímicas, que foram também descritas neste capítulo. Além do mais, nas quatro oportunidades foram colhidas amostras de todos os animais de cada um dos cabris selecionados e esses animais, no momento da colheita das amostras eram submetidos a exame clínico completo.

Os cabris e animais criados nos 13 municípios de São Paulo foram utilizados para determinar a prevalência e incidência regionais da infecção pelo vírus da Artrite-encefalite dos Caprinos e para avaliar a influência de fatores sexuais, raciais e do manejo de criação sobre os índices de infecção, a população de animais foi redistribuída em grupos experimentais homogêneos, segundo delineamento específico para, ao final, apresentar real contribuição para esclarecimentos de vários conceitos da etiopatogenia da enfermidade.

A população utilizada para aclarar as hipóteses consideradas foi sumarizada e caracterizada no Quadro 4, onde destacou-se: o cabril; o município de localização do criatório; o tipo 
de manejo (sistema de criação utilizado) e o número de caprinos existentes nos planteis, nos quatro momentos do exame dos animais e colheita das amostras.

\subsubsection{Levantamento preliminar dos rebanhos}

$\mathrm{Na}$ seleção dos plantéis que integrariam esta pesquisa, os criatórios foram visitados, momento em que se aplicou um questionário adrede preparado para caracterizar-se cada propriedade estudada, com o intuito de se avaliar as condições físicas do cabril, assim como o manejo alimentar e sanitário a que eram submetidos os animais, tipo de exploração, número de cabeças criadas, raça, sexo e idade dos animais. A seguir, os caprinos dessas propriedades eram clinicamente avaliados e colhidas as amostras de sangue, para obtenção do soro sangüíneo de cada caprino, sendo as amostras, em todas as fases de manipulação, convenientemente identificadas, registrando-se a idade, sexo e raça. 
Quadro 4 - Caracterização da população de caprinos utilizados para formação de grupos experimentais da presente pesquisa. Distribuição segundo o número de amostras de soro sangüíneo colhidas nos quatro momentos, município de origem e o tipo de criação. São Paulo, 2002.

\begin{tabular}{|c|c|c|c|c|c|c|c|}
\hline \multirow{2}{*}{ Cabril } & \multirow[b]{2}{*}{ Município } & \multirow{2}{*}{$\begin{array}{l}\text { Tipo de } \\
\text { criação }\end{array}$} & \multicolumn{5}{|c|}{ No. de amostras colhidas } \\
\hline & & & $\begin{array}{c}1^{\mathrm{a}} \cdot \\
\text { colheita }\end{array}$ & $\begin{array}{c}2^{2} \cdot \\
\text { colheita }\end{array}$ & $\begin{array}{c}3^{2} \cdot \\
\text { colheita }\end{array}$ & $\begin{array}{c}4^{\mathrm{a}} \cdot \\
\text { colheita }\end{array}$ & Total \\
\hline 1 & São Roque & Intensivą & 18 & 18 & 29 & 25 & 90 \\
\hline 2 & Ibiúna & Intensiva & 24 & 20 & 26 & $26^{\circ}$ & 96 \\
\hline 3 & Vargem Grande & Intensivạ & 134 & 150 & 138 & 157 & 579 \\
\hline 4 & Paulista & Semi-extensiva & 33 & 34 & 40 & 39. & 146 \\
\hline 5 & Piedade & Semi-extensiva & 30 & 45 & 55 & 74 & 213 \\
\hline 6 & Itapecirica da Serra & Semi-extensiva & 64 & 56 & 61 & 79 & 260 \\
\hline 7 & Marília & Semi-extensiva & 28 & 43 & 41 & 42 & 154 \\
\hline 8 & Itapetininga & Semi-extensiva & 94 & 86 & 79 & 71 & 330 \\
\hline 9 & Salesópolis & Semi-extensiva & 20 & 16 & 20 & $15^{\circ}$ & 71 \\
\hline 10 & Arapeí . & Semi-extensiva & 36 & 33 & 36 & 29. & 134 \\
\hline 11 & Pindamonhangaba & Intensiva & 53 & 111 & 124 & 91 & 379 \\
\hline 12 & Cotia & Intensiva & 71 & 82 & 74 & 38 . & 265 \\
\hline 13 & $\begin{array}{l}\text { Bragança } \\
\text { Paulista }\end{array}$ & Intensiva & 106 & 116 & 119 & 106 & 447 \\
\hline 14 & Vargem & Intensivạ & 31 & 25 & 29 & 31 & 116 \\
\hline & TOTAL & & 751 & 835 & 871 & 823 & 3.280 \\
\hline
\end{tabular}


Como o projeto da pesquisa estava incluído em programa específico de saúde animal, com controle e supervisão clínica veterinária aos proprietários envolvidos na presente pesquisa, eram recomendadas medidas de prevenção e controle para a Artrite-encefalite dos Caprinos. As principais recomendações foram:

1. exames imuno-sorológicos de todo o plantel a cada 6 meses;

2. abate dos animais sororeagentes quando a freqüência detectada no rebanhofosse de até $10 \%$;

3. apartar as crias logo após o nascimento;

4. oferecer aos recém-nascidos somente colostro e leite de cabra pasteurizado ousubstitutos;

5. identificação dos animais soropositivos através do uso de brincos ou medalhas diferenciando-os dos animais soronegativos;

6. separação dos animais soropositivos, formando assim dois plantéis, um formado por caprinos sadios e outro constituído por caprinos sororeagentespositivos para AEC;

7. priorizar a ordem da ordenha - primeiro as fêmeas negativas;

8. implantar as necessárias condições para melhorar as condições de higiene, alimentação e acomodação dos caprinos soropositivos, utilizando como rotinaa desinfecção com vassoura de fogo (quando plausível seu emprego);

9. recomendar e adotar o uso de material descartável (luvas, agulhas, seringas,lâminas de bisturi...); 
10. desinfecção rigorosa dos seguintes materiais e equipamentos a seguir relacionados:

a) para identificação dos caprinos: tatuadores e aplicadores de brincos;

b) para inseminação artificial e sincronização de cio - agulhas, seringas,instrumental específico para inseminação artificial e/ou exame ginecológico/andrológico;

c) equipamentos e material cirúrgico, de descorna ou das demais práticasde produção animal;

11. programação ${ }^{1}$ do abate dos caprinos soropositivos.

12. aquisição somente de caprinos - reprodutores e matrizes sabidamente soronegativos e de plantéis sanitariamemte controlados e atestados pela CAPRIPAULO;

13. orientação, treinamento e conscientização de funcionários do cabril e/ou correlacionados da necessidade e importância do manejo clínico-sanitário epreventivo, para impedir a contaminação do rebanho e/ou controlar a ocorrência da infecção nos efetivos do plantel da Artrite-encefalite dos Caprinos.

\subsubsection{Características particulares dos 14 cabris utilizados no Delineamento experimental para avaliaçõesclínico-epidemiológicas da Artrite-encefalite dos Caprinos.}

\section{Cabril 1}

O cabril 1, localizado no município de São Roque, era constituídopor cerca de 22 caprinos da raça Saanen, criados em sistema intensivo, em área de 13hectares; desses animais foram colhidas 90 amostras de soro sangüíneo. As instalações eram tipo galpão, o piso era elevado do solo do tipo ripado, formandogaiolas coletivas cada uma com espaço para até 5 animais. A alimentação básica eraconstituída por ração concentrada comercial, na quantidade de 600 gramas/fêmea/dia,adicionandose feno, capim picado e sal mineral ad libitum, para todos os animais. Aprodução média diária de leite era de 3,5 litros por cabra, em sistema de ordenhamanual, não constituindo um linha de ordenha, sem funcionário uniformizado, masobedecendo normas rígidas de higiene na ordenha e pós-ordenha:

Observacão: : a taxa de descarte, nos rebanhos paulista de Caprinos, varia em torno de 20,0\%, mas naprogramação estabeleceu-se que seria importante, que no período de dois anos já se tivesse eliminado os caprinos reagentes soropositivos. O critério e prioridade de seleção dos enfermos para descarte por abate foram: emagrecimento progressivo, queda da produção leiteira e infertilidade. 
utilizando toalhasde papel e soluções à base de iodo para desinfecção dos tetos na pré e pós-ordenha. Oaleitamento dos cabritos era natural, e quando havia necessidade de utilização de mamadeiras estas eram lavadas com soluções aquosas de cloro. O controle sanitáriodo plantel de caprinos incluía vacinações coletivas contra as principais enfermidadesinfecciosas da região, vermifugações a cada 3 meses e controle sistemático de ectoparasitoses. A identificação dos caprinos era feita pela colocação de brincos nosfilhotes e de tatuagem nos adultos, sendo a desinfecção dos equipamentos para aplicação do sistema de marcação feita com álcool iodado. Para tratamento medicamentoso dos caprinos, quando necessário, empregavam-se seringas e agulhas descartáveis, utilizando um conjunto por animal e o material cirúrgico era esterelizadopor fervura. As gaiolas e baias onde os caprinos permaneciam eram lavadas com águaclorada e feita, a seguir, varredura com a "vassoura de fogo". Na avaliação do histórico do plantel o proprietário não relatou a ocorrência de mamite, de diarréia noscabritos, de pneumonias ou de artrites. O manejo reprodutivo baseava-se na montacontrolada ou na inseminação artificial. Em resumo, tratava-se de um rebanho fechado, e quando era adquirido um novo animal este permanecia isolado em quarentena, e o proprietário solicitava a realização de exame sorológico para pesquisade anticorpos anti-vírus da Artrite-encefalite dos Caprinos. Deste rebanho, foramcolhidas quatro amostras de todos os caprinos presentes no cabril 1 durante o período de dois anos. As características específicas do rebanho: raça, sexo e faixa etária, dos animais do cabril 1 foram detalhadas no Quadro 5. 


\section{Cabril 2}

No.cabril 2, localizado em Ibiúna, eram criados cerca de 24 animaisda raça Alpina em sistema intensivo de criação, numa área de·31 hectares, dos quaisforam colhidas 96 amostras de soro sangüíneo As instalações eram do tipo galpãocom os animais mantidós em gaiolas com piso ripado e suspenso. Os caprinos eramalimentados com ração concentrada comercial, complementada com feno de alfafa esal mineral ad libitum. O sistema de ordenha era manual, com produção média diáriade leite de 2,5 litros por cabra. Os utensílios de uso na ordenha eram primeiramentelavados com água e sabão e, a seguir, imersos em água clorada durante 15 minutos. Oaleitamento dos cabritos era natural, até os 45 dias de idade. O controle sanitário erafeito por exames coproparasitológicos periódicos, com vermifugações uma vez aoano ou quando fosse necessário, segundo a interpretação clínica dos exames parasitológicos e controle de ectoparasitoses. Periodicamente, o plantel era vacinadocontra enfermidades infecciosas mais comuns na região. O sistema de identificaçãobaseava-se na utilização de brincos plásticos, mas empregavia-se tamibém a identificação por tatuagem, sendo a desinfecção do aplicador de brincos e do tatuadorrealizada átravés dả fervura em água durante 5 minutơs. As seringas, agulhas e lâminas de bisturi utilizadas no tratamento dos caprinos eram descartáveis. As baiaseram, eventualmente, lavadas com jatos d'água com pressão. No levantamento dohistórico do plantel do Cabril 2, o proprietário relatou a ocorrência de três casos demamite e alguns casos de diarréia em caprinos adultos, quando recebiam forrageirasem fase de brotamento. Não houve relatos da ocorrência de casos clínicos de pneumonias ou de artrite no rebanho. Em relação ao manejo reprodutivo, constatou-se que a cobertura era realizada por monta controlada e por inseminação artificial. Emresumo, este plantel pôde ser considerado como de rebanho fechado e nenhum animal tinha sido, recentemente, introduzido. No cabril 2 foram feitas quatro amostragens, no período de dois anos, sendo colhidas amostras de todos os animaispresentes no momento das colheitas. As características específicas dos caprinos dorebanho, como raça, sexo e faixa etária, foram transcritas no Quadro 6. 
용

톤

들

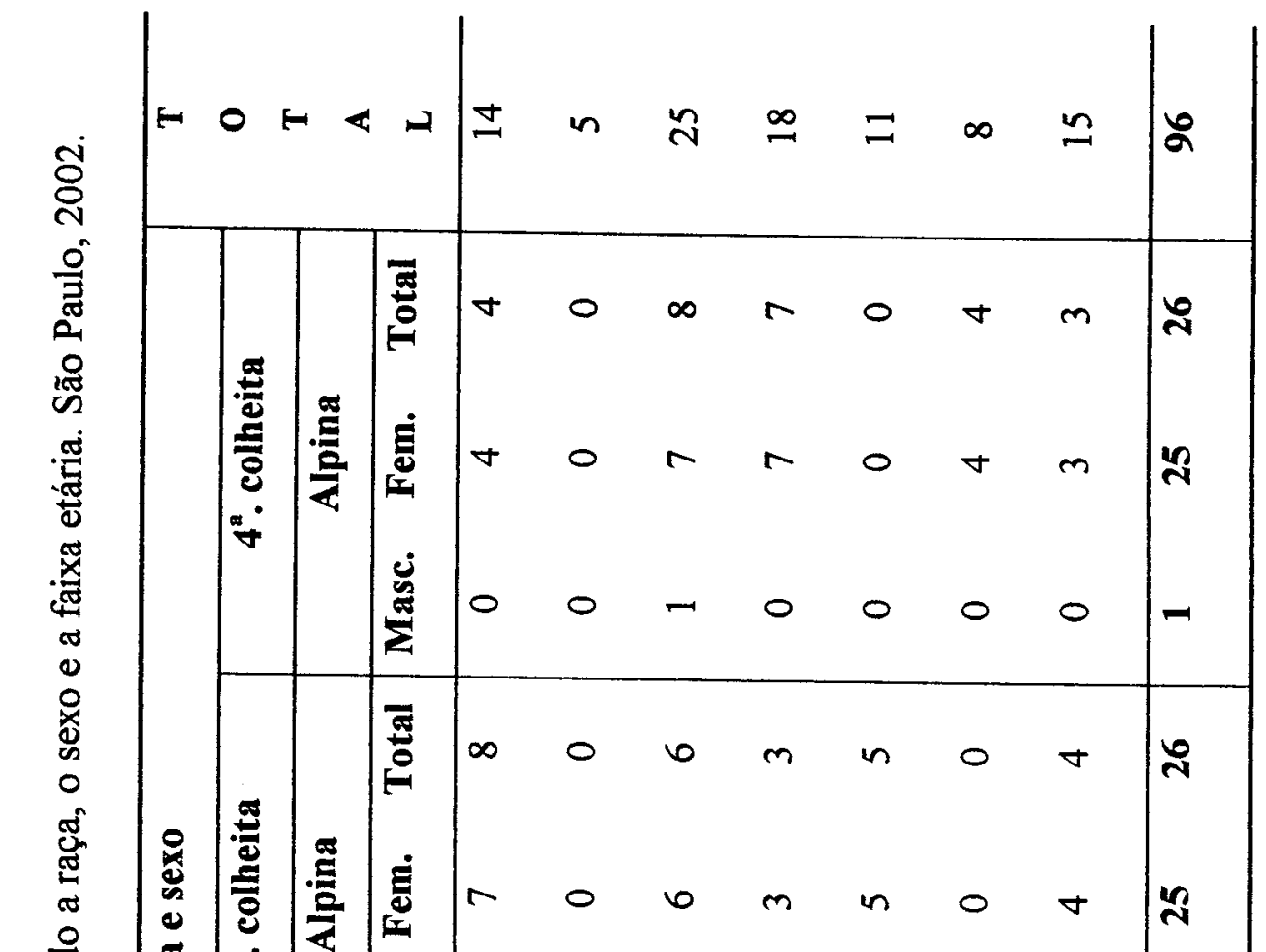

过

웅

래

는

త్ర్రే

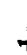

.

总 ช

壳

ㅁ.

용

웡

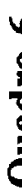

\begin{tabular}{|c|c|c|c|c|c|c|c|c|c|c|c|}
\hline 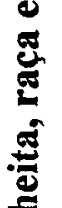 & लं & 7 & 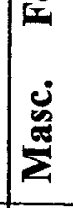 & -7 & 0 & 0 & 0 & 0 & 0 & 0 & $\Rightarrow$ \\
\hline 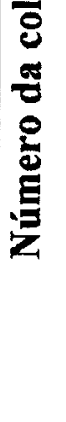 & 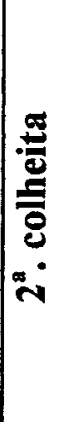 & 产 & 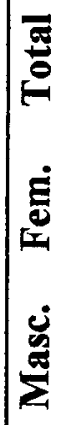 & $\begin{array}{l}0 \\
0 \\
0\end{array}$ & $\begin{array}{l}0 \\
0\end{array}$ & N & $N$ & in & - & $\begin{array}{l}n \\
n\end{array}$ & 워 \\
\hline & 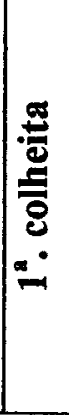 & 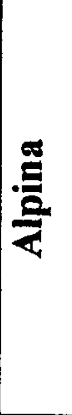 & 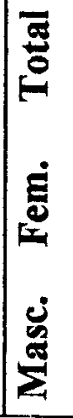 & $\begin{array}{l}N \\
0\end{array}$ & 0 & 0 & 0 & $r$ & $m$ & $m$ & $\begin{array}{l}\text { त } \\
\text { 궁 }\end{array}$ \\
\hline 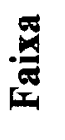 & 䜦 & Eี & 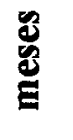 & $\stackrel{b}{v}$ & $\frac{N}{\frac{N}{1}}$ & $\frac{\stackrel{\sim}{N}}{\stackrel{N}{\sim}}$ & $\begin{array}{l}\stackrel{D}{m} \\
\stackrel{+}{+}\end{array}$ & $\begin{array}{l}\stackrel{\infty}{+} \\
\stackrel{0}{\circ} \\
m\end{array}$ & $\begin{array}{l}8 \\
\frac{8}{+} \\
\stackrel{\infty}{+}\end{array}$ & $\begin{array}{l}8 \\
\wedge\end{array}$ & $\stackrel{\bar{\pi}}{0}$ \\
\hline
\end{tabular}




\section{Cabril 3}

Neste terceiro cabril, possuidor de uma área de 57 hectares,localizado no município de Vargem Grande Paulista, eram criados aproximadamente145 caprinos das raças Saanen (137), Alpina (5) e Mestiça (3), em sistema de manejointensivo, dos quais foram colhidas 579 amostras de soro sangüíneo. As instalaçõeseram do tipo galpão, de piso ripado e suspenso. Os caprinos eram alimentados comração concentrada elaborada na propriedade, associada à distribuição $\quad$ ad libitum defeno, capim picado e sal mineral. O sistema de ordenha utilizava ordenhadeira mecânica, constituindo uma linha de ordenha. A produção média diária de leite doplantel era de 3,5 litros por cabra. Os utensílios da ordenha, após seu uso, eramlavados com água e detergente apropriado para lavagem de ordenhadeiras mecânicas.Os cabritos mamavam o colostro diretamente em suas mães e após esses período oaleitamento era artificial controlado, até os cabritos completarem dois meses de idade,usando mamadeira individual. Os caprinos jovens eram mantidos em cabriteiro coletivo. O controle clínico sanitário do plantel incluía exames coproparasitológicosrealizados a cada seis meses em amostragem, representativa, sendo as vermifugaçãofeitas quando necessário, pela interpretação clínica dos exames parasitológicos. Alémdo mais, para manter a higidez dos espécimes do plantel, rotineiramente eram realizadas vacinações para profilaxia das principais doenças infectocontagiosasregionais; como também era feito rotineiro controle de piolhos e carrapatos. O sistema de identificação dos caprinos baseava-se no uso de colar com placa metálicade identificação e tatuagem, sendo a desinfecção do tatuador realizada por sua imersão, e dos números, em álcool durante 10 minutos. No tratamento dos animais,somente eram utilizadas seringas e agulhas descartáveis. O manejo reprodutivo doscaprinos do plantel era por monta controlada. Este, também, era um plantel fechado,sem a introdução de caprinos oriundos de outras propriedades. Durante o período de2 anos foram colhidas quatro amostras de sangue para obtenção de soro sangüíneo,de todos os caprinos mantidos no cabril, no momento das colheitas. As características dos animais do Cabril 3, segundo a raça, faixa etária e sexo dos caprinos foram distribuídos nos Quadros 7, 8 e 9. 


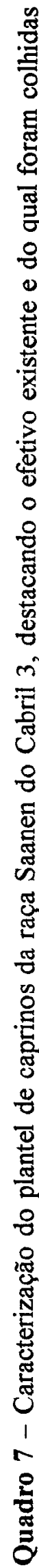

\begin{tabular}{|c|c|c|c|c|c|c|c|c|c|c|c|}
\hline$H$ & 0 & \multicolumn{2}{|c|}{$E<-$} & 5 & $\infty$ & $\cong$ & 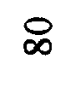 & g & \& & 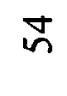 & in \\
\hline \multirow{4}{*}{ 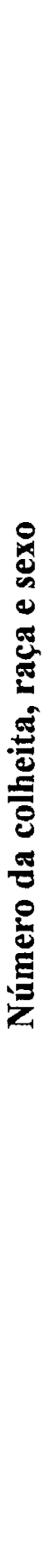 } & 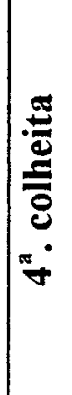 & 胥 & 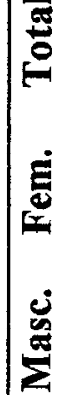 & $\begin{array}{c}m \\
m \\
m\end{array}$ & $\begin{array}{l}\mathbb{N} \\
\mathbb{N}\end{array}$ & $\begin{array}{l}\stackrel{\mathscr{F}}{ } \\
\stackrel{\vartheta}{\forall}\end{array}$ & 2 & $\equiv$ & $n$ & $\cong$ & F \\
\hline & 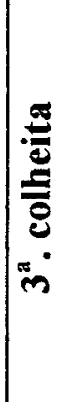 & 忢 & 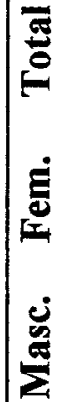 & ส & n & $\begin{array}{l}\vec{N} \\
\vec{N}\end{array}$ & $\because$ & - & $a$ & $\stackrel{\infty}{=}$ & ิㅗ \\
\hline & 焉 & 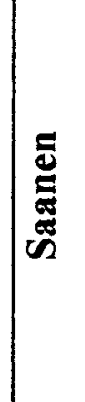 & 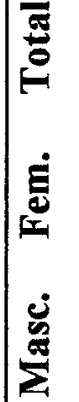 & $\begin{array}{c}\infty \\
\infty \\
\infty \\
\infty \\
m\end{array}$ & $\begin{array}{l}a \\
a\end{array}$ & ì & $\begin{array}{c}\bar{m} \\
\text { 을 }\end{array}$ & $\begin{array}{l}- \\
-\end{array}$ & $\because$ & $\begin{array}{l}\simeq \\
\simeq\end{array}$ & 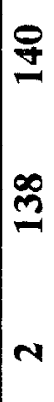 \\
\hline & 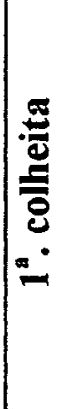 & 苞 & 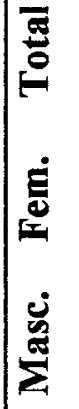 & $\begin{array}{l}\simeq \\
\simeq\end{array}$ & $\cong$ & ষ & 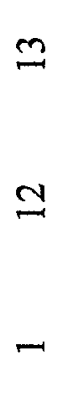 & $\tilde{\sim}$ & $\begin{array}{l} \\
\end{array}$ & $a$ & $\Xi$ \\
\hline 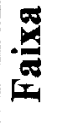 & 丞 & 플 & 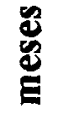 & 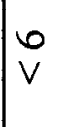 & $\frac{\Upsilon}{\frac{1}{0}}$ & $\begin{array}{l}\stackrel{ \pm}{T} \\
\stackrel{\sim}{N}\end{array}$ & $\begin{array}{l}\stackrel{0}{m} \\
\stackrel{+}{\sim}\end{array}$ & 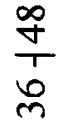 & $\begin{array}{l}8 \\
\stackrel{8}{+} \\
\stackrel{\infty}{+}\end{array}$ & $\begin{array}{l}8 \\
1\end{array}$ & है \\
\hline
\end{tabular}




.

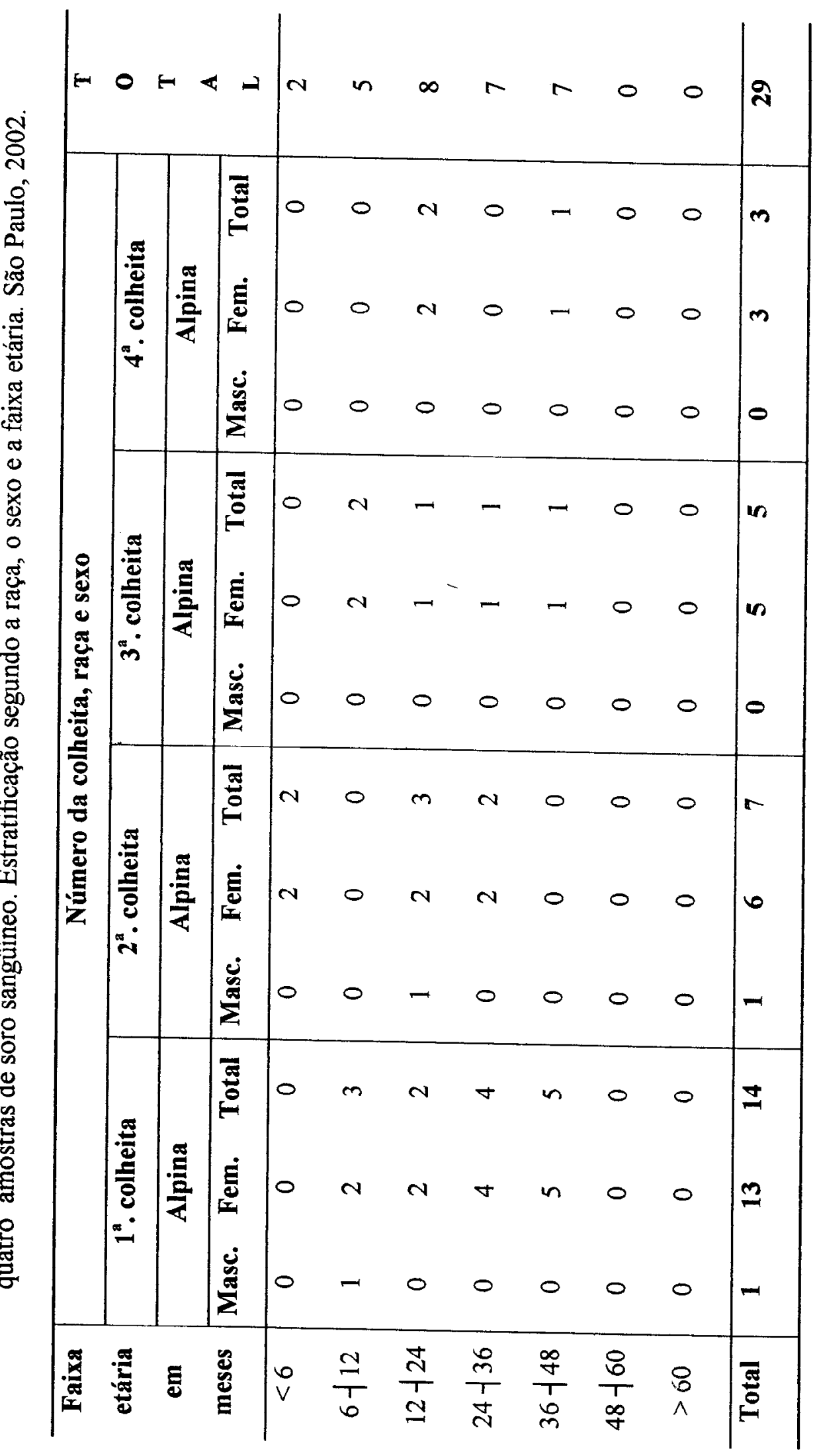




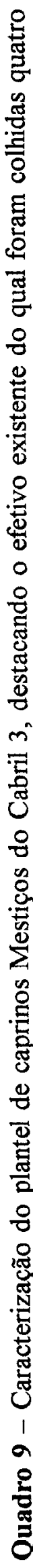

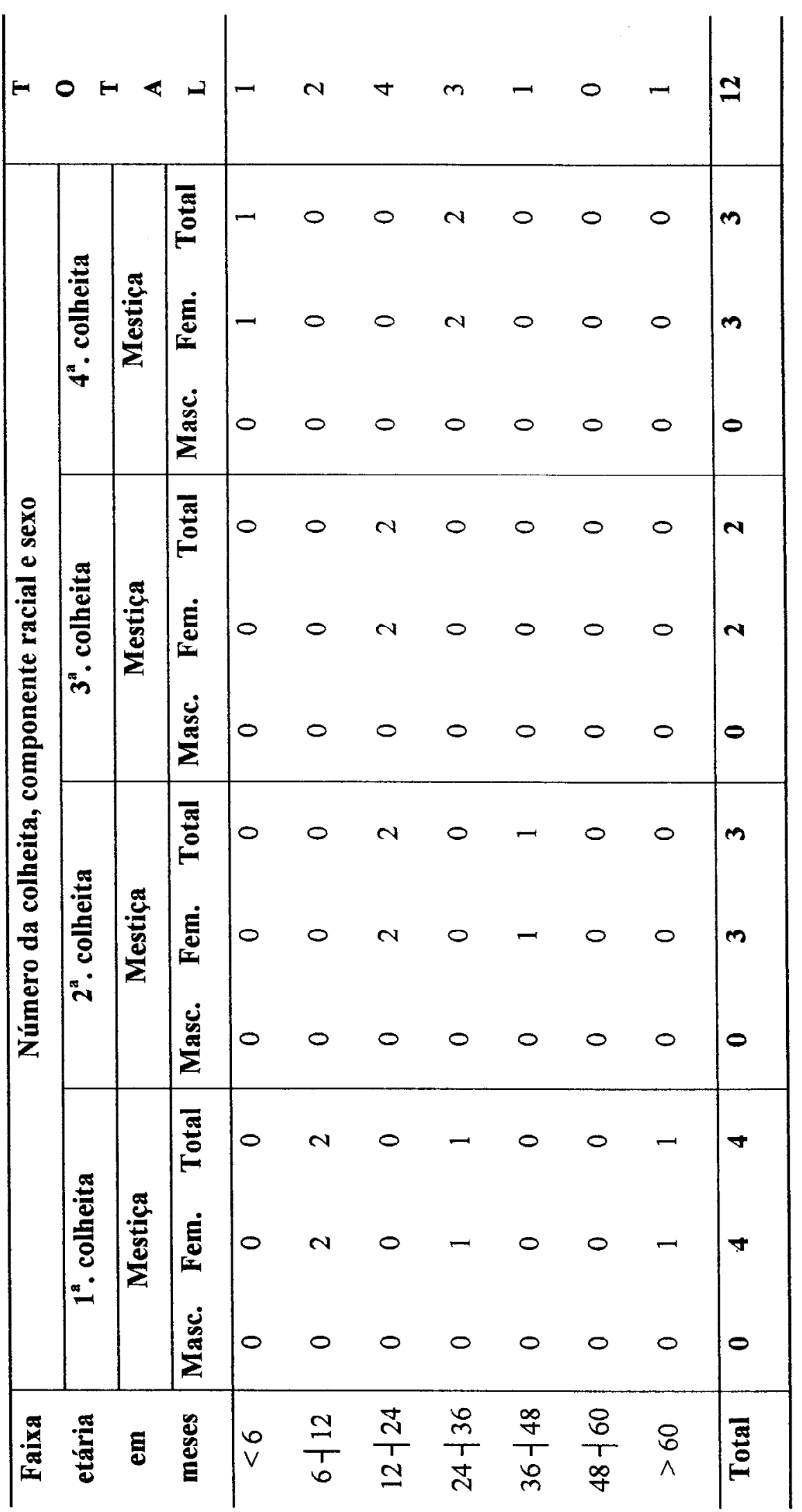




\section{Cabril 4}

O cabril 4, situado no município de Piedade, numa área de 10 hectares, eram mantidos num sistema semi-extensivo de criação, ao redor de 36 caprinos da raça Alpina (18) e animais Mestiços (18), das quais foram colhidas 146amostras de soro sangüíneo. As instalações eram do tipo galpão, com ripado suspenso, dividido em baias de $8 \mathrm{~m}^{2}$, sendo ocupadas no máximo por cinco animais.Os caprinos adultos recebiam, como alimentação 100 g diárias de ração concentradacomercial, além de capim Napier ou Guandu picado e sal mineral ad libitum. A produção média diária de leite era de 1 litro por cabra, submetidas a sistema de ordenha manual, com linha de ordenha. Os funcionários não trabalhavam uniformizados, mas eram convenientemente preparados para conduzirem a ordenhahigiênica, usando soluções à base de iodo para a proteção pós-ordenha dos tetos elavagem e secagem do úbere com toalha de papel individual na fase de higienizaçãopré-ordenha. Os utensílios e equipamentos de ordenha e de aleitamento eram lavadoscom água e detergente e mantidos imersos em água com hipoclorito. Os cabritoslactentes submetiam-se ao aleitamento natural, e quando necessário fazia-se uso demamadeiras com leite de cabra in natura. O controle clínico-sanitário do plantel erafeito com vermifugações coletivas a cada 3 meses, sem prévia avaliação da intensidade das endoparasitoses, por exames coproparasitológicos. Como complementação dos cuidados sanitários de controle do rebanho, as seringas e agulhas eram descartáveis. O sistema de identificação consistia na colocação de colares com placas metálicas, onde inscrevia-se o número dos animais. As baias edemais instalações acessíveis aos caprinos eram varridas e polvilhadas com cal virgem uma vez por mês. Na avaliação dos antecedentes do criatório, o proprietárionão relatou a ocorrência de artrite acometendo os animais do rebanho. O sistema demanejo reprodutivo baseava-se na cobertura das matrizes por monta natural controlada, utilizando bodes do plantel. Esta propriedade era um rebanho fechado enenhum animal foi adquirido durante os dois anos de duração e desenvolvimento dapresente pesquisa. Todos os animais foram examinados no momento da colheita das quatro amostras de sangue. As características do plantel do Cabril 4, quanto a raça, idade e sexo dos animais foram transcritas nos Quadros 10 e 11. 
政

\begin{tabular}{|c|c|c|c|c|c|c|c|c|c|c|c|}
\hline$H$ & \multicolumn{3}{|c|}{$0 F<-2$} & $\simeq$ & $\equiv$ & \pm & $a$ & $\simeq$ & $\infty$ & 0 & N \\
\hline \multirow{4}{*}{ 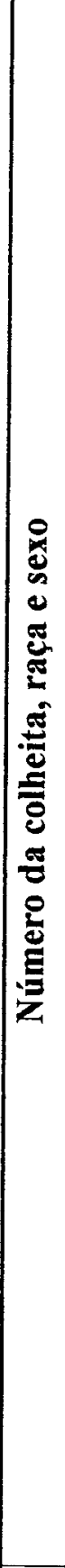 } & ن & $\frac{a}{\frac{\pi}{2}}$ & 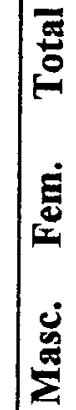 & 0 & $\begin{array}{l}\simeq \\
\simeq\end{array}$ & $n$ & 0 & $\nabla$ & $m$ & 0 & 竎 \\
\hline & & $\frac{\text { 歌 }}{2}$ & 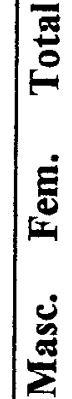 & $\begin{array}{l}\simeq \\
\simeq\end{array}$ & $\begin{array}{l}0 \\
0\end{array}$ & $\begin{array}{l}n \\
n\end{array}$ & $\begin{array}{l}0 \\
0\end{array}$ & $n$ & $m$ & 0 & - \\
\hline & 莡 & $\frac{\mathscr{a}}{\underline{\underline{\partial}}}$ & | & $\begin{array}{l}0 \\
0\end{array}$ & $\begin{array}{l}n \\
n\end{array}$ & $\begin{array}{l}0 \\
0\end{array}$ & $\begin{array}{l}n \\
\nabla\end{array}$ & $m$ & - & $\begin{array}{l}0 \\
0\end{array}$ & $\begin{array}{l} \pm \\
\simeq\end{array}$ \\
\hline & 吾 & 总 & 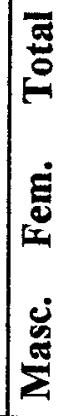 & $\begin{array}{l}0 \\
0 \\
0\end{array}$ & $\begin{array}{l}0 \\
0\end{array}$ & $\nabla$ & $\nabla$ & 0 & - & 0 & 10 \\
\hline 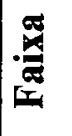 & 䜦 & ్ㅠㅇ & 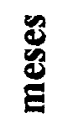 & 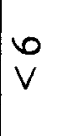 & $\frac{\sim}{\frac{1}{\sigma}}$ & $\frac{\mathbb{N}}{\stackrel{T}{\simeq}}$ & $\begin{array}{l}\stackrel{\circ}{\stackrel{m}{+}} \\
\stackrel{\sim}{N}\end{array}$ & $\begin{array}{l}\stackrel{\infty}{+} \\
\frac{1}{0} \\
\text { m }\end{array}$ & $\frac{8}{\frac{8}{1}}$ & $\begin{array}{l}\stackrel{8}{0} \\
\wedge\end{array}$ & $\Phi$ \\
\hline
\end{tabular}




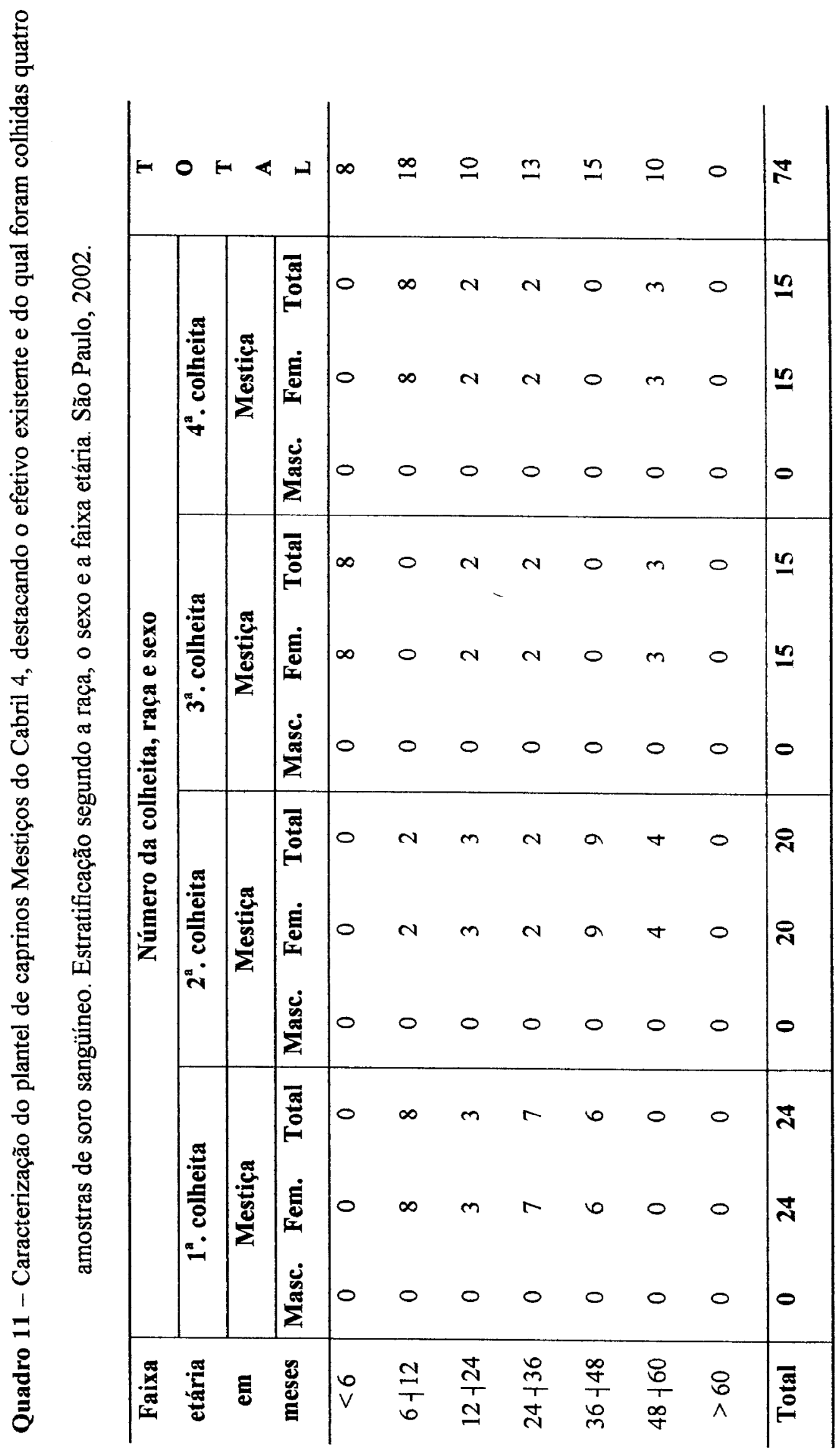




\section{Cabril 5}

O Cabril 5, localizado no município de Itapecirica da Serra, era constituído de aproximadamente 53 caprinos da raça Saanen. Deste plantel foramcolhidas 213 amostras de soro sangüíneo. Os caprinos deste plantel eram mantidosem sistema semi-extensivo de criação, tendo à disposição área de quatro hectares,com instalações do tipo galpão, com piso ripado e suspenso, sendo os animais mantidos em baias coletivas, no máximo quatro animais por baia. Em relação aomanejo alimentar, verificou-se ser esta uma criação orgânica de caprinos, sendo oleite produzido e seus derivados (iogurte e queijo), vendidos no mercado de formadiferenciada, assim sendo, recebiam dieta especial, com o concentrado elaborado napropriedade e de origem controlada, sem agrotóxicos. A produção média diária deleite era de 3 litros por cabra, com sistema de ordenha manual. Para higienização daordenha lavava-se o úbere antes da ordenha e sua secagem era feita com tolhas depapel e soluções a base de iodo. Ao final da ordenha os utensílios e equipamentosusados eram lavados com água clorada e detergente. O aleitamento dos cabritos eraartificial e controlado, sendo ao cabrito neonato administrado colostro de cabra, nãopasteurizado e a seguir leite de vaca pasteurizado. O sistema de aleitamento doscabritos utilizava mamadeiras coletivas, que após seu uso eram limpas e lavadas comdetergente e água clorada, para a seguir serem submetidas à fervura. Estes cabritoseram mantidos em cabriteiro coletivo.O controle parasitário era realizado com a utilização de produtos homeopáticos, orientados por decisão clínica de exames coproparasitológicos periódicos. O sistema de identificação utilizado baseava-se nacolocação de colares com medalhas identificadoras e de tatuagem, sendo a desinfecção do tatuador feita por limpeza e lavagem com soluções cloradas, seguidasde fervura. As baias eram limpas com retirada dos detritos e a seguir varridas com"vassoura de fogo" e polvilhadas com cal virgem. O manejo reprodutivo era conduzido segundo sistema de monta controlada ou inseminação artificial. Do planteldeste Cabril 5, foram colhidas amostras de todos os animais no momento das quatrocolheitas programadas para a duração deste estudo. As características dos animais dorebanho, segundo a raça, sexo e faixa etária, foram detalhadas no Quadro 12. 


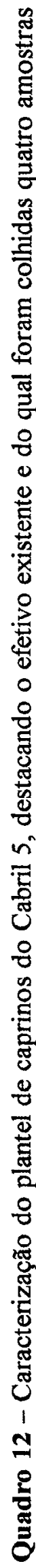

\begin{tabular}{|c|c|c|c|c|c|c|c|c|c|c|c|}
\hline$H$ & 0 & \multicolumn{2}{|c|}{4} & $\mathscr{q}$ & 오 & $\stackrel{n}{+}$ & m & $\ddot{\sim}$ & 9 & 오 & $\frac{2}{9}$ \\
\hline \multirow{4}{*}{ 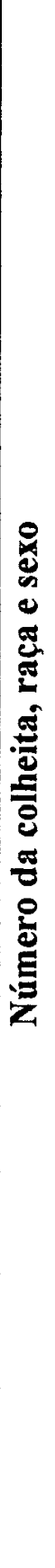 } & 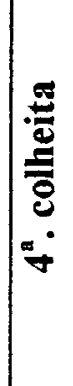 & 志 & 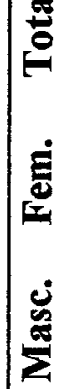 & 궁 & $\begin{array}{l}0 \\
0\end{array}$ & $\begin{array}{l}\mathscr{0} \\
\simeq\end{array}$ & $\begin{array}{l}= \\
a\end{array}$ & $\begin{array}{l}0 \\
0\end{array}$ & $a$ & $\begin{array}{l}n \\
n\end{array}$ & 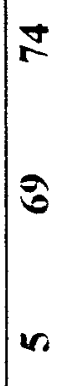 \\
\hline & & 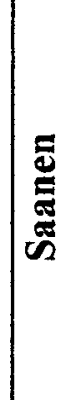 & 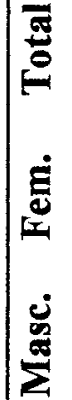 & $\begin{array}{l}= \\
0\end{array}$ & $\begin{array}{l}a \\
a\end{array}$ & $\begin{array}{l}\text { 음 } \\
\text { a }\end{array}$ & $a$ & $\forall$ & r & n & $\frac{n}{n}$ \\
\hline & نَّ & 总 & 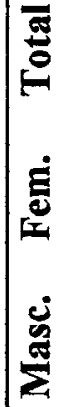 & $\begin{array}{l}a \\
a\end{array}$ & $\begin{array}{l}- \\
-\end{array}$ & $\begin{array}{l}= \\
a\end{array}$ & $\infty$ & $a$ & $\begin{array}{l}N \\
N\end{array}$ & $n$ & $\begin{array}{l}F \\
\mathcal{F}\end{array}$ \\
\hline & 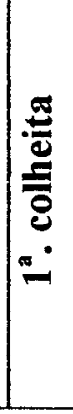 & 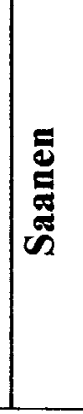 & 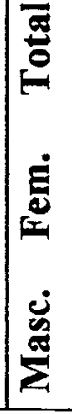 & $\begin{array}{c}2 \\
- \\
-\end{array}$ & $\begin{array}{l}\circ \\
a\end{array}$ & $\infty$ & $a$ & $\nabla$ & - & $n$ & $\begin{array}{l}\tilde{m} \\
\mu\end{array}$ \\
\hline 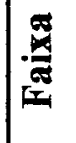 & 祂 & छํㅇ & $\begin{array}{l}\mathscr{U} \\
\mathbb{E} \\
\mathbb{E}\end{array}$ & $\begin{array}{l}b \\
v\end{array}$ & $\frac{N}{T}$ & 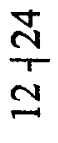 & $\begin{array}{l}\stackrel{0}{m} \\
\stackrel{m}{r} \\
\stackrel{d}{d}\end{array}$ & $\frac{\infty}{+}$ & $\frac{8}{\not 1}$ & $\begin{array}{l}8 \\
\wedge\end{array}$ & Eี \\
\hline
\end{tabular}




\section{Cabril 6}

Neste sexto cabril, localizado em Marília, eram criados aproximadamente 65 caprinos das raças Saanen (51) e Alpina (14), em sistema intensivo, numa área de 96 hectares; deste plantel foram colhidas 260 amostras desoro sangüíneo. O alojamento dos animais era do tipo galpão, os caprinos permaneciam em gaiolas com piso ripado e suspenso. Os animais eram alimentadoscom ração concentrada elaborada na propriedade. O sistema de ordenha era manual,formando linha de ordenha. A produção média diária de leite era 2,5 litros por cabra.Os utensílios utilizados na ordenha eram lavados com água e detergente. Os cabritos, mantidos em cabriteiro coletivo, eram submetidos a aleitamento artificial controlado,com sistema de mamadeiras coletivas, sendo a eles administrado colostro de vaca innaturae a seguir, o aleitamento era com leite de vaca. Os utensílios usados no aleitamento eram lavados com água quente e detergente. O controle clínico-sanitáriodos caprinos do plantel consistia em vermifugações coletivas a cada 3 meses, além docontrole de ectoparasitoses com pulverização de produtos ectoparasiticidas. Ainda visando controlar enfermidades infecto-contagiosas, as seringas, agulhas e material deinseminação eram todos descartáveis. Com igual finalidade, as gaiolas e galpão eramvarridos para retirada de detritos e a seguir submetidos a ação de "vassoura de fogo",para finalmente nelas se polvilhar cal virgem. O proprietário relatou, como antecedentes do criatório, a ocorrência de mamite e alguns casos de diarréia emcabritos na fase imediata do pós-desmame, alguns casos de pneumonia em animaisadultos, não relatando, todavia, a ocorrência de artrite no rebanho. O manejo da reprodução obedecia as normas da cobertura por monta controlada e por inseminação artificial. Nesse rebanho fazia-se verificações esporádicas da ocorrênciada Artrite-encefalite dos Caprinos e os efetivos sororeagentes aos antígenos do víruscausador da doença eram descartados do rebanho. Neste Cabril 6 todos os animaisforam examinados e, deles, colheram-se quatro amostras de sangue durante os doisanos de duração da pesquisa. As características específicas dos animais do plantel,como raça, sexo e faixa etária, foram transcritas nos Quadros 13 e 14. 


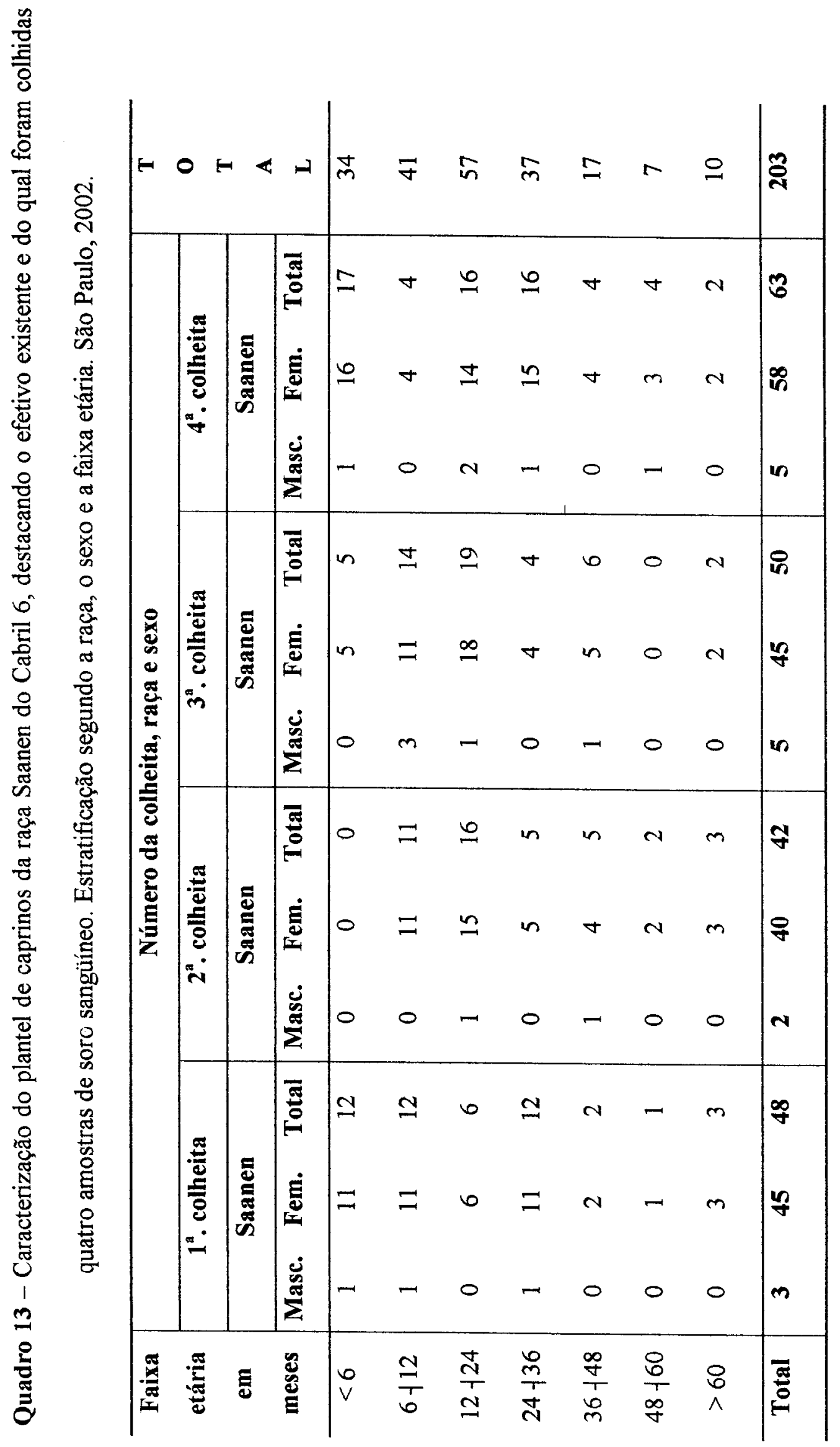


急

톤

즐

욤

,

$\stackrel{0}{\circ}$

$\frac{1}{3}$

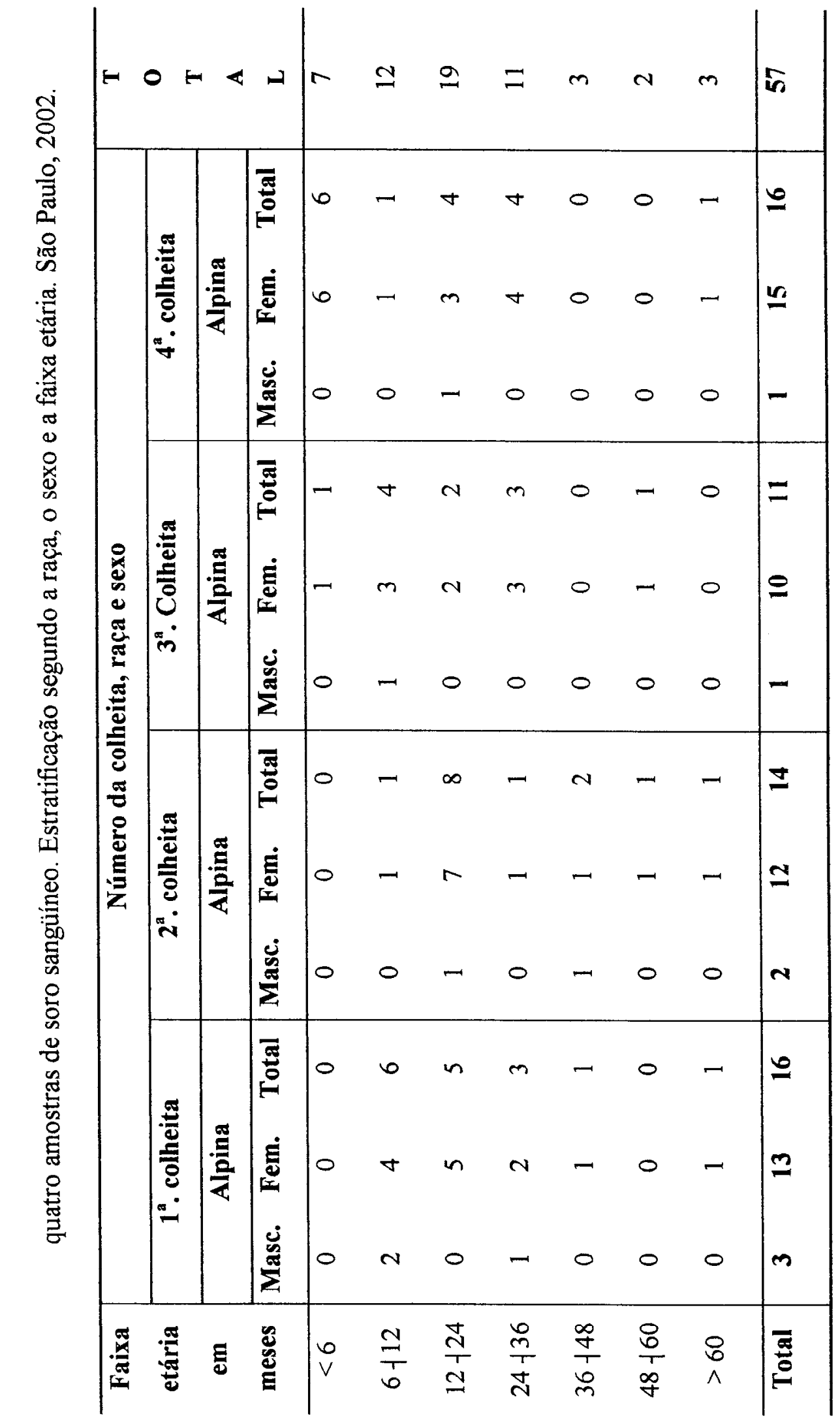




\section{Cabril 7}

O Cabril 7, situado numa propriedade de 1,5 hectares, localizada no município de Cotia, eraconstituído por cerca de 39 caprinos da raça Alpina, que foram configurados no Quadro 15. Desses animais foramcolhidas 154 amostras de sangue, para obtenção de soro sangüíneo. Os animais desse Cabril eram criados obedecendoas normas do sistema semi-extensivo, em instalações do tipo galpão com piso ripado e suspenso, com baias de $4 \mathrm{~m}_{2} \mathrm{com}$ capacidade para 2 animais. A alimentação, basicamente, consistia de ração concentrada comercial, sendo ministrado aos caprinos em quantidade variável, segundo sua categoria: $1,5 \mathrm{~kg}$ por dia para as fêmeas em lactação e 1,0kg por dia para os demais participantes do plantel. Feno de Coast-Cross, cortes picados de capim Napier e o sal mineraleram oferecidos ad libitumao rebanho. A ordenha era manual, formando linha de ordenha, com funcionários uniformizados, que eram responsáveis pela higiene da ordenha, cujas medidas constavam de: desinfecção dos tetosutilizando solução à base de iodo nas fases pré e pós-ordenha; lavagem e secagem do úbere com toalhas individuais depapel. A produção média diária de leite no plantel era de 2,5 litros por cabra. Os utensílios da ordenha eram lavadoscom água, detergente e desinfetante. Os cabritos mamavam o colostro e o leite direto de suas mães, portanto oaleitamento era natural até os animais completarem 2 meses de idade. O manejo clínico-sanitário baseava-se narealização de exames coproparasitológicos periódicos e vermifugações massais de 4 em 4 meses. A limpeza das baiasera feita, inicialmente, pela remoção mecânica dos detritos e a seguir aplicava-se a varredura com "vassoura de fogo",polvilhando-se cal virgem sobre o piso. O sistema de identificação dos caprinos do plantel era feito pela colocação decolar com medalhas metálicas, nas quais figurava o nome e número do animal; além disso usavam-se, também,tatuagem, sendo a desinfecção do aparelho de tatuar realizada com álcool. No tratamento curativo ou profilático doscaprinos, somente eram utilizadas seringas e agulhas descartáveis. O sistema de manejo de reprodução do plantelobedecia as normas da monta controlada. Durante o período de 2 anos foram colhidas quatro amostras de sorosangüíneo dos caprinos mantidos no criatório, além do mais, esses animais foram submetidos a exame clínico. 
J

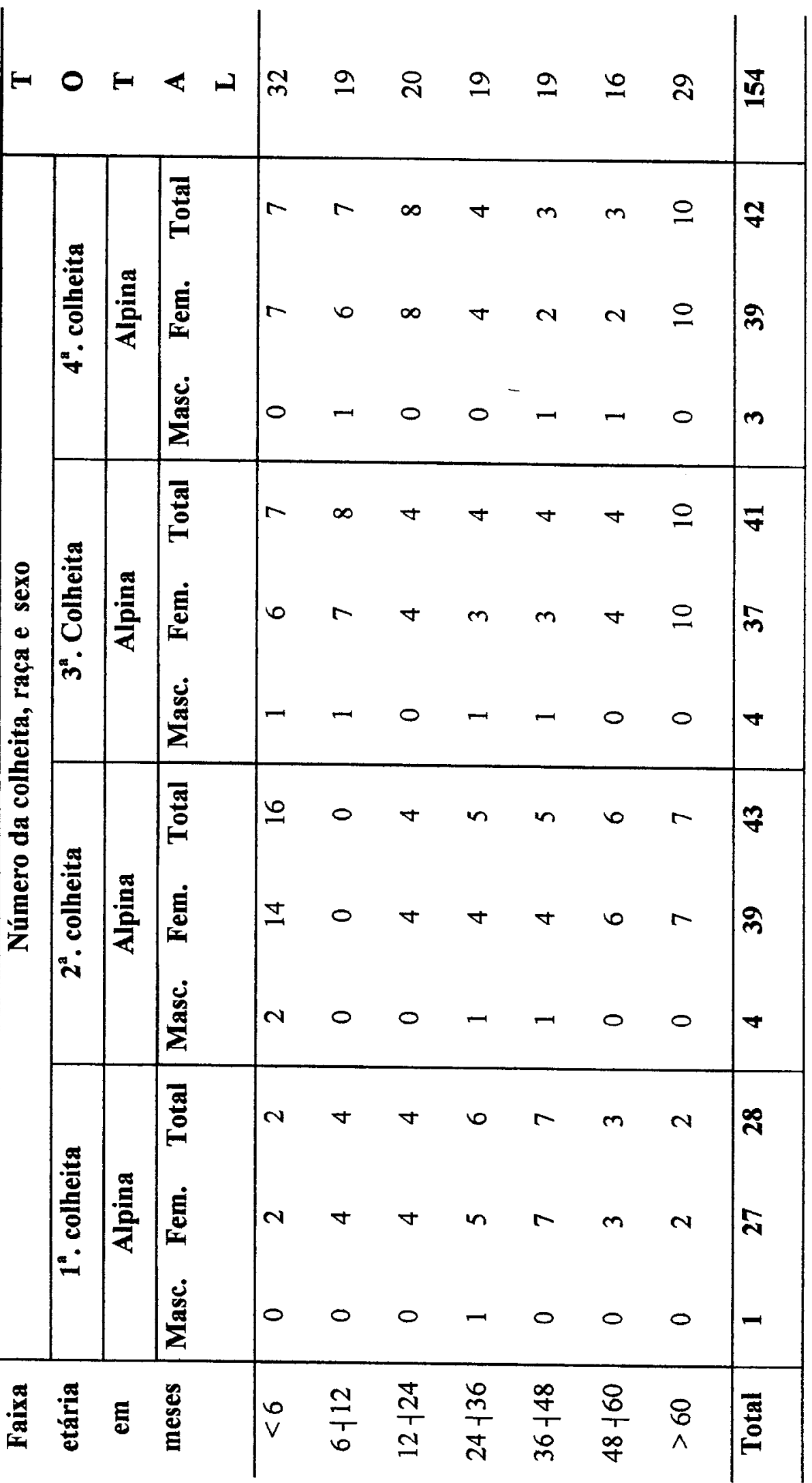




\section{Cabril 8}

O Cabril 8, inscrito na circunscrição do município de Itapetininga, era constituído por cerca de 82 caprinos, das raças Saanen (79) e Bôer (3), dos quais colheram-se 330amostras de soro sangüíneo, durante a fase experimental desta tese, criados em sistema semi-extensivo, em área de 160 hectares, sendo as instalações do tipo térreo, com solo forrado porcama de palha de arroz. Os animais eram mantidos em baias coletivas com $12 \mathrm{~m}_{2}$ de área.Segundo o manejo alimentar dos caprinos deste plantel, os animais recebiam diariamente raçãocomercial e feno e sal mineral ad libitum. A produção média diária de leite era de 2 litros porcabra, em regime de ordenha manual, com linha de ordenha e os funcionários trabalhavamuniformizados.Nas fases pré e pós-ordenha, os tetos eram desinfetados com soluções à base deiodo. Para limpeza dos utensílios utilizados na ordenha, eles eram inicialmente, lavados comágua e detergente, e a seguir com água clorada. O controle clínico sanitário do plantel, consistiana realização rotineira da inspeção do leite, antes da ordenha, em caneca telada com fundoescuro, utilizando-se a prova do CMT para pesquisa de leite mamitoso. O aleitamento dos cabritos era natural, com ingestão do colostro e leite materno. A profilaxia das doenças infectocontagiosas prevalentes na região era feita por vacinações coletivas, associavam-se ao processoexames coproparasitológicos periódicos e vermifugações quando necessário, além do controlede ectoparasitoses. O sistema de identificação utilizado era o de colocação de brincos, sendo adesinfecção do aplicador realizada através da imersão do material em álcool 70\%. A cama dasbaias era trocada uma vez por mês. Os administradores, ao se referirem aos antecedentes doplantel, relataram a ocorrência de artrite e mamite, mas não de pneumonias ou diarréia. Omanejo reprodutivo obedecia as normas da cobertura com monta controlada. Periodicamente,caprinos do plantel eram submetidos a exame imuno-sorológico para Artrite-encefalite dosCaprinos. Aqueles com resultado positivo eram descartados do rebanho. Deste Cabril foramcolhidas quatro amostras de todos os animais presentes no plantel na oportunidade, durante osdois anos de duração desta pesquisa. A distribuição dos animais do Cabril 8, segundo a raça,sexo e faixa etária, foi apresentada nos Quadros 16 e 17. 


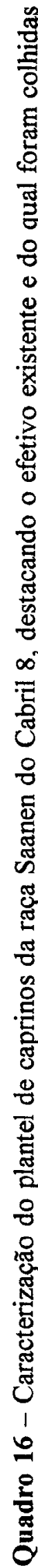

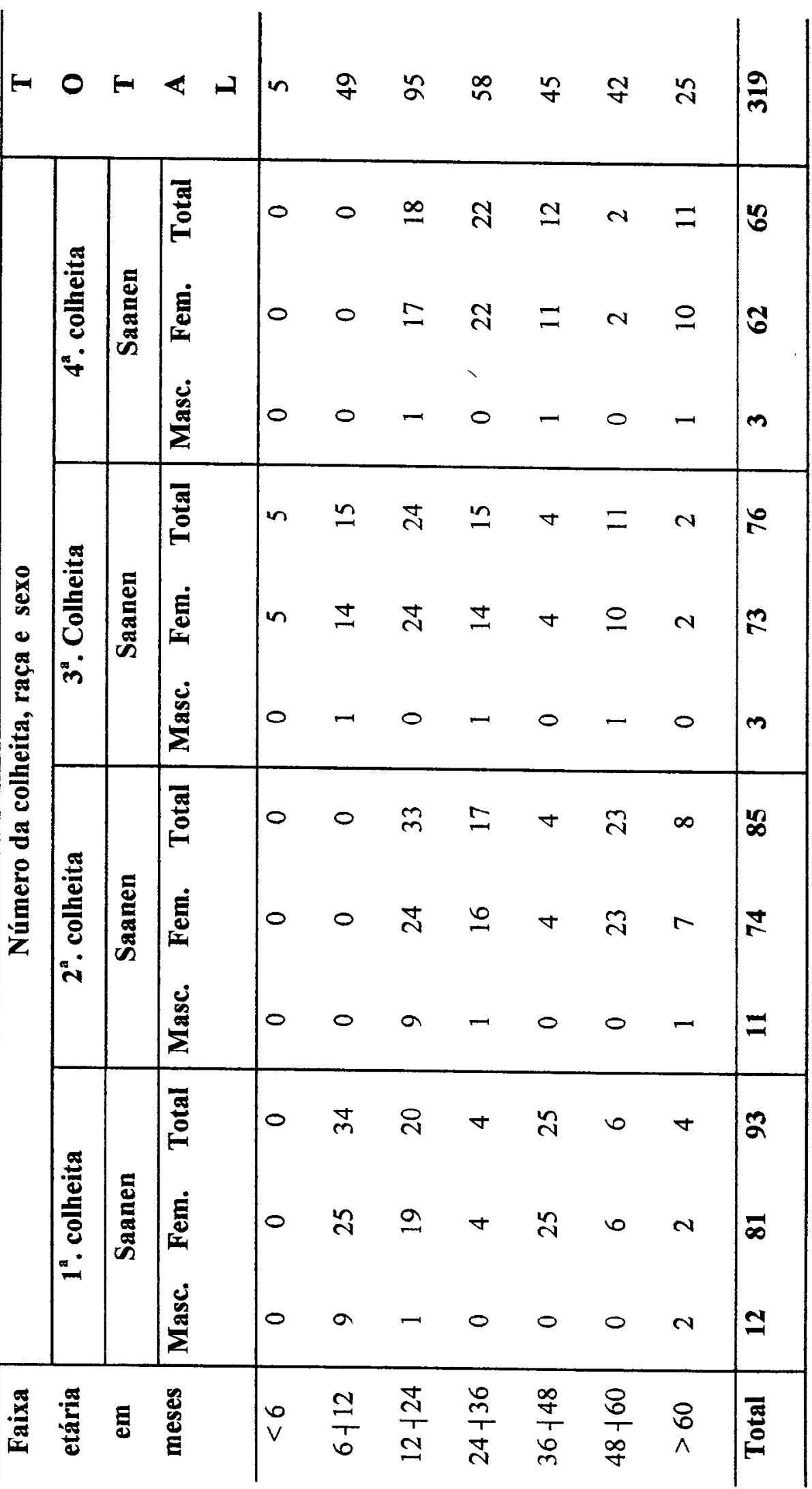




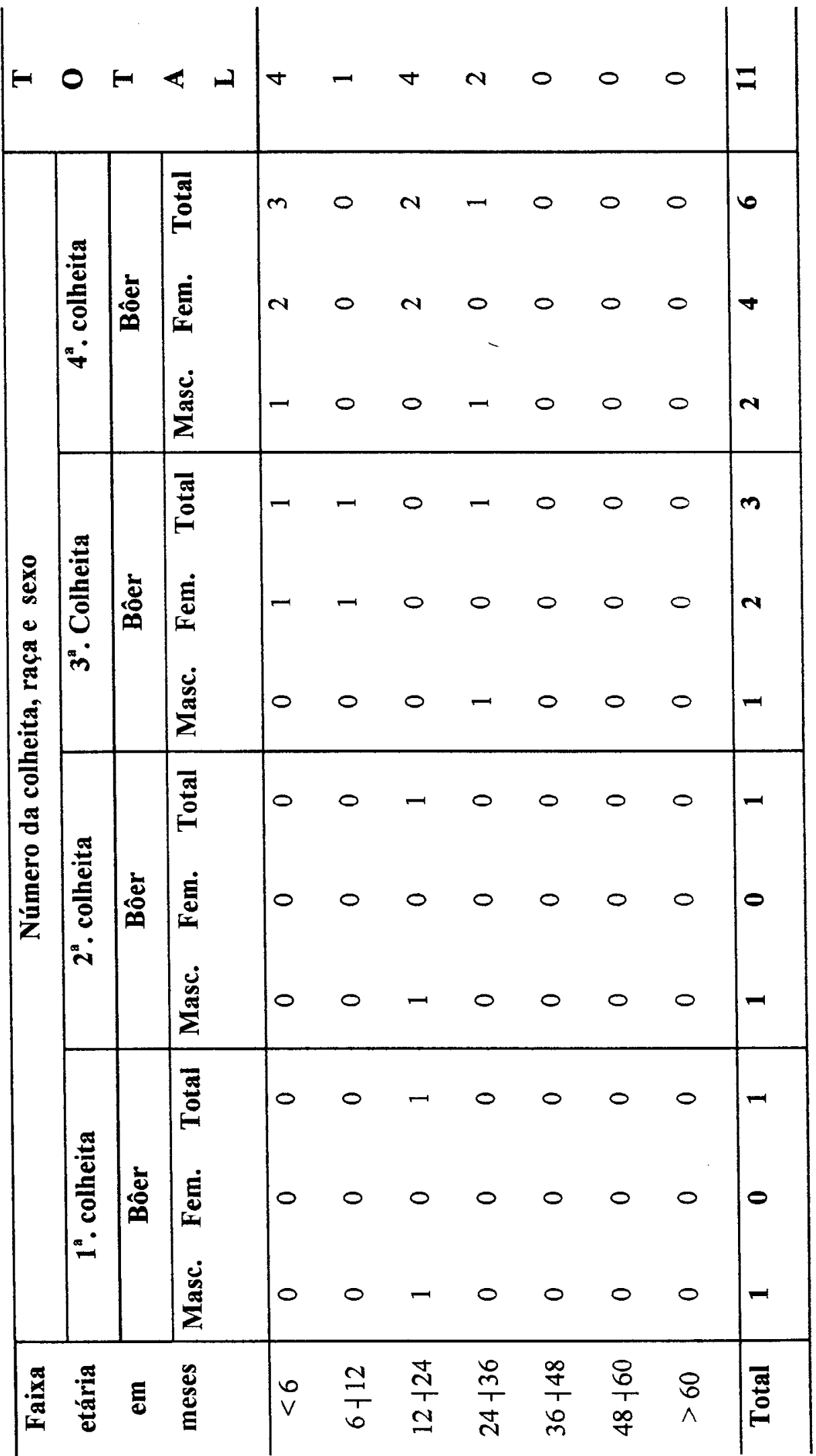




\section{Cabril 9}

O Cabril 9 pertencia à circunscrição do município de Salesópolis, numa áreatotal de 13 hectares, dedicava-se à criação, em sistema intensivo, de cerca de 18 caprinos da raçaSaanem e dos quais colheram-se 71 amostras de soro sangüíneo. Suas instalações eram do tipogalpão com piso ripado e suspenso, com divisões em baias de $12 \mathrm{~m}_{2}$. A alimentação dos animaisera feita com ração concentrada comercial, associada a administração de capim picado e salmineral ad libitum. A produção média diária de leite era de 2,3 litro por cabra, em regime deordenha manual, sem ter à disposição sala ou plataforma de ordenha. Os utensílios de usodiário na ordenha, bem como aqueles utilizados no aleitamento dos cabritos lactentes, eramlavados com água fervida e água clorada. $\mathrm{O}$ controle clínico-sanitário do plantel era feito pelavacinação dos animais contra a raiva e com vermifugações coletivas aplicadas duas vezes aoano, isto é, a cada 6 meses. O cabritos, que eram mantidos em aprisco coletivo, mamavam ocolostro direto na mãe, imediatamente após o nascimento e após este período os animais recebiam, até dois meses de idade, leite das cabras sem pasteurização, em mamadeiras. Para ocontrole da Artrite-encefalite dos Caprinos realizavam-se exames imunosorológicos periódicose os animais sororeagentes positivos eram descartados do plantel, por abate. O sistema de identificação utilizado baseava-se, fundamentalmente, em dois métodos: brincos e tatuagem. Adesinfecção dos equipamentos de colocação dos brincos e de tatuagem era feita com álcooliodado, após limpeza com água e detergente. No trato clínico dos caprinos, utilizavamseseringas, agulhas, luvas e material de inseminação artificial descartáveis. A limpeza das baias eoutros locais de permanência dos animais era executada por varredura uma vez ao dia. Oproprietário, durante o levantamento do histórico clínico do plantel, relatou a ocorrência deartrite em alguns caprinos. No sistema de manejo reprodutivo do plantel, as fêmeas eram cobertas por monta natural controlada e inseminação artificial, utilizando sêmen importado.Todos os animais deste plantel foram examinados e deles colhidas quatro amostras de sorosangüíneo. As características específicas dos caprinos do plantel do Cabril 9, foram detalhadasno Quadro 18, obedecendo distribuição segundo a raça, idade e sexo dos animais. 


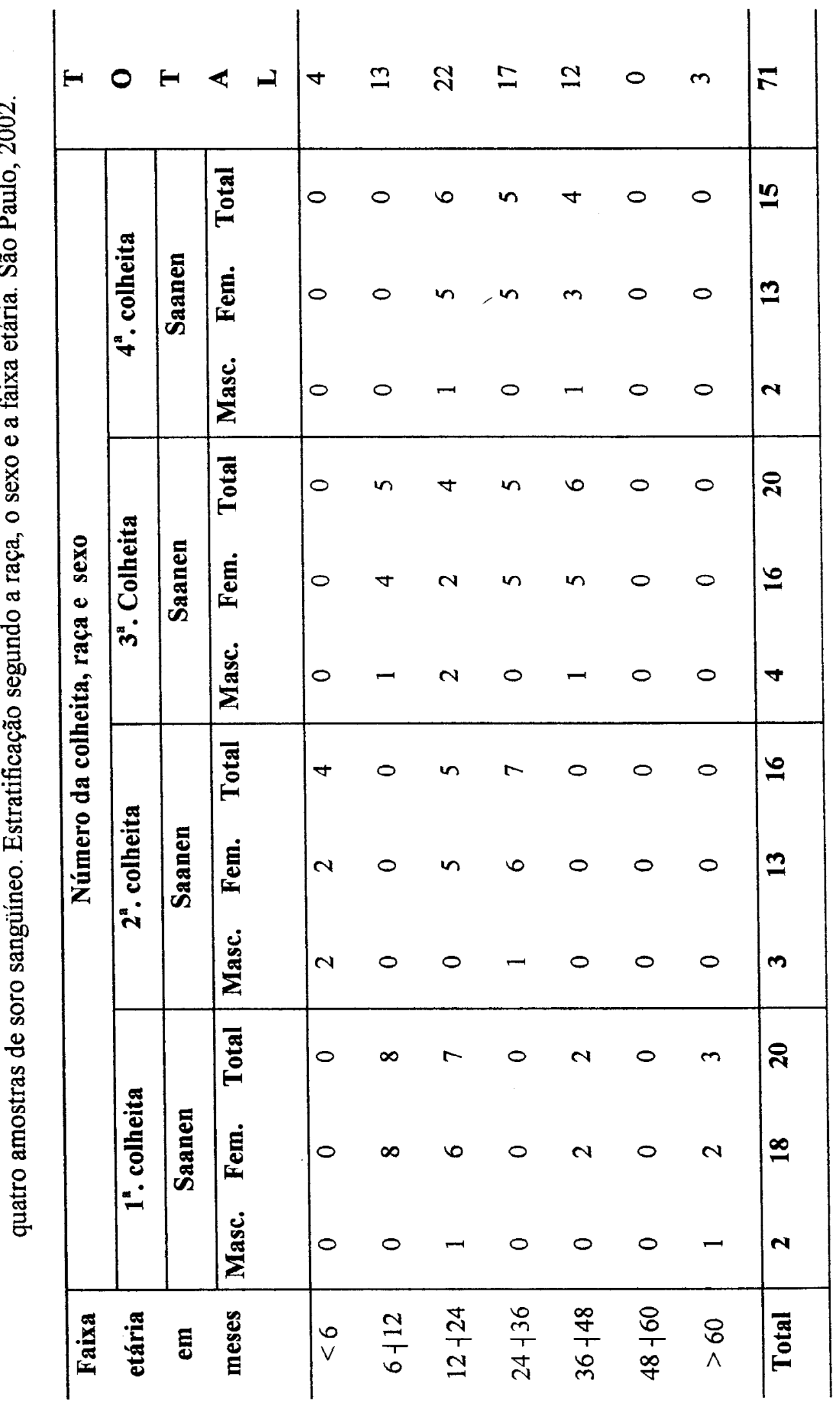




\section{Cabril 10}

O décimo plantel, incluído no delineamento experimental desta tese, localizava-se no município de Arapeí, eram criados cerca de 34 caprinos da raça Saanen, emsistema semi-extensivo, numa área de 5 hectares, e dos quais colheram-se 134 amostras de sorosangüíneo; as instalações eram do tipo galpão, com os animais mantidos em gaiolas, com pisoripado e suspenso, medindo $6 \mathrm{~m}^{2}$; os cabritos lactentes permaneciam em aprisco coletivo. Osanimais eram alimentados com 500 gramas diárias de ração concentrada comercial,adicionando-se na dieta capim picado e sal mineral ad libitum. O sistema de ordenha utilizadonesta criação de caprinos leiteiros era manual, com produção média diária de 3,5 litros de leitepor animal, não havendo nas instalações sala ou plataforma de ordenha. O aleitamento doscabritos lactentes era artifical e controlado, utilizando mamadeiras individuais; inicialmente, aoneonato, imediatamente após o nascimento, era administrado colostro de vaca, e a seguir aleitados com leite de vaca. Os equipamentos e utensílios usados na ordenha e no aleitamentodos cabritos eram lavados com água e detergente. O controle clínico-sanitário era feito porvacinação dos caprinos contra a febre aftosa e raiva, e por vermifugações coletivas a cada doismeses. As seringas e agulhas quando utilizadas no tratamento curativo e/ou profilático eramdescartáveis. Como sistema de identificação dos animais, utilizavam-se brincos plásticos e tatuagem, sendo a desinfecção do material de identificação realizada por imersão em álcool.Para limpeza das baias, após remoção mecânica dos detritos, por varredura, a desinfecção dolocal era feita com soluções a base de fenol e iodo, finalizando-se com polvilhação de calvirgem. O proprietário do Cabril 10, ao fazer o histórico clínico, relatou a ocorrência de artriteem alguns caprinos adultos, não referiu casos de mamite ou pneumonias. O manejo reprodutivo obedecia às regras corriqueiras do sistema de coberturas por monta natural. Oplantel do Cabril 10 foi examinado nos quatro momentos da colheita das amostras de sangue,para obtenção de soro sangüíneo, no período de dois anos de duração desta pesquisa. As características específicas dos caprinos do plantel do Cabril 10, distribuídas segundo a raça, sexoe faixa etária dos animais foram sumarizadas no Quadro 19. 


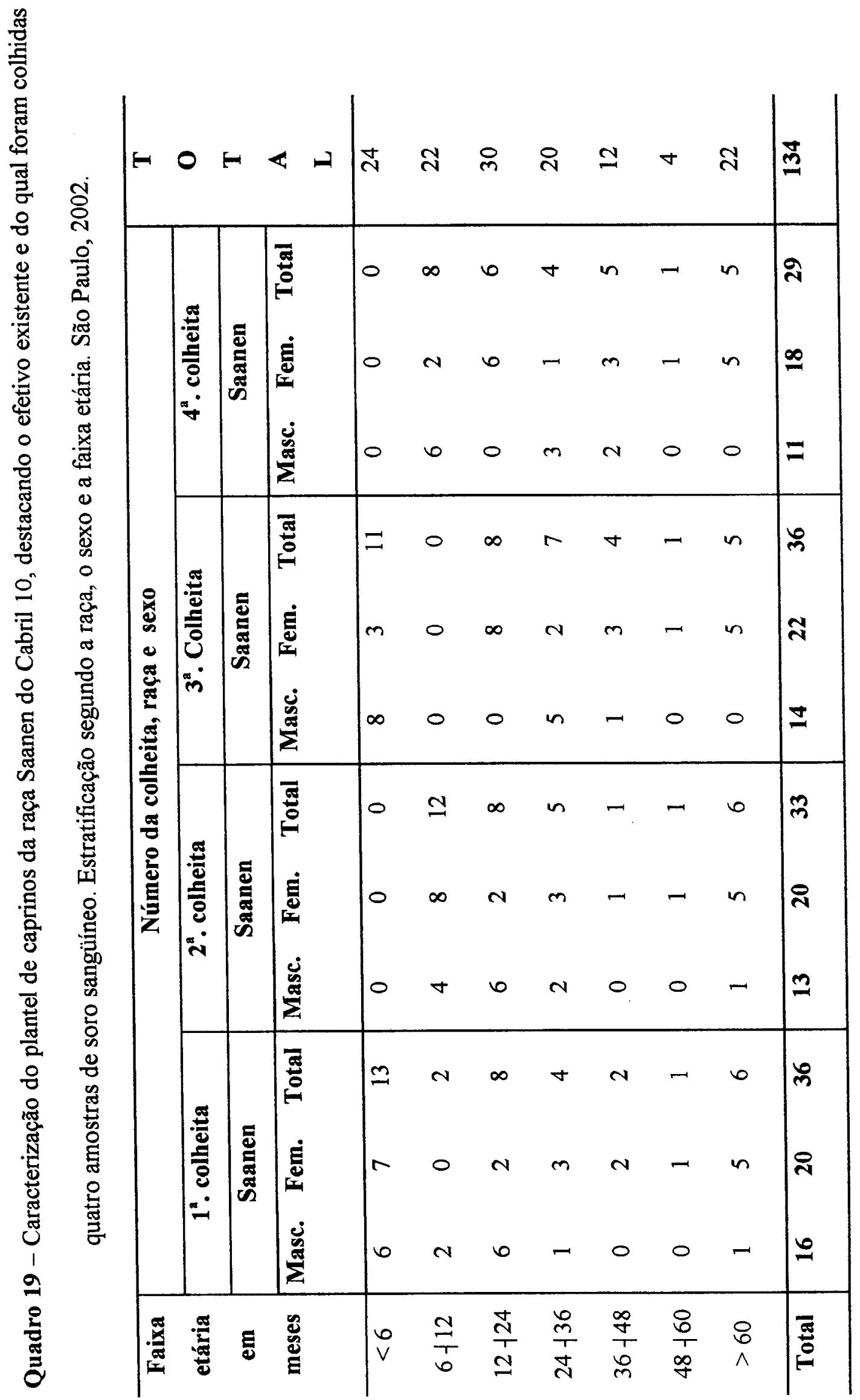




\section{Cabril 11}

No cabril 11, localizado no município de Pindamonhangaba, criavamseaproximadamente 95 caprinos, numa área de 15 hectares, em sistema intensivo de criação, pertencentes às raças Saanen (59) Alpina (16), Anglo Nubiana (7) e Toggenbourg (13), dos quaiscolheram-se 379 amostras de soro sangüíneo. As características específicas dos animais desteplantel, separadas pela raça e estratificados segundo a faixa etária e sexo, foram detalhadas nosQuadros 20, 21, 22 e 23. As instalações obedeciam as normas usuais dos apriscos térreos, nãousando cama como cobertura do piso. O sistema e manejo alimentar consistia no fornecimentodiário de ração concentrada comercial, além de capim picado e sal mineral ad libitum. A produção média diária de leite era de 3 litros por cabra, com ordenha manual em instalação quecontinha sala e plataforma de ordenha. Os utensílios de ordenha e de aleitamento eram lavadoscom água e detergente. O aleitamento dos cabritos era natural, consistindo na mamada docolostro materno e aleitamento por mamar na mãe. Entre as mamadas os cabritos lactenteseram mantidos em apriscos coletivos. Como controle clínico-sanitário faziam-se, apenas, vermifugações coletivas a cada seis meses. O sistema de identificação utilizado baseava-se nacolocação de colares com medalhas de plástico, onde se escreviam o nome e número do animal,associando-se a esse processo, também, o uso de tatuagem. O equipamento usado nesse processo de identificação não era submetido a nenhum método de desinfecção, nem se utilizavam materiais descartáveis. A limpeza das baias consistia na remoção do excesso de fezes, uma vez por mês. O manejo reprodutivo obedecia as normas do sistema que recomendacoberturas por monta à natural, com os reprodutores livres no campo. Não eram obedecidasqualquer norma vigente para controlar a ocorrência da Artrite-encefalite dos Caprinos, apesarde serem realizados periódicos exames sorológicos para evidenciação dos caprinos infectadospelo vírus determinante da enfermidade. Além disso, foram adquiridos e introduzidos inúmeros animais no rebanho, sem exame imuno-sorológico, prévio ou submissão à quarentena. 
్ㅠㅁ

قु

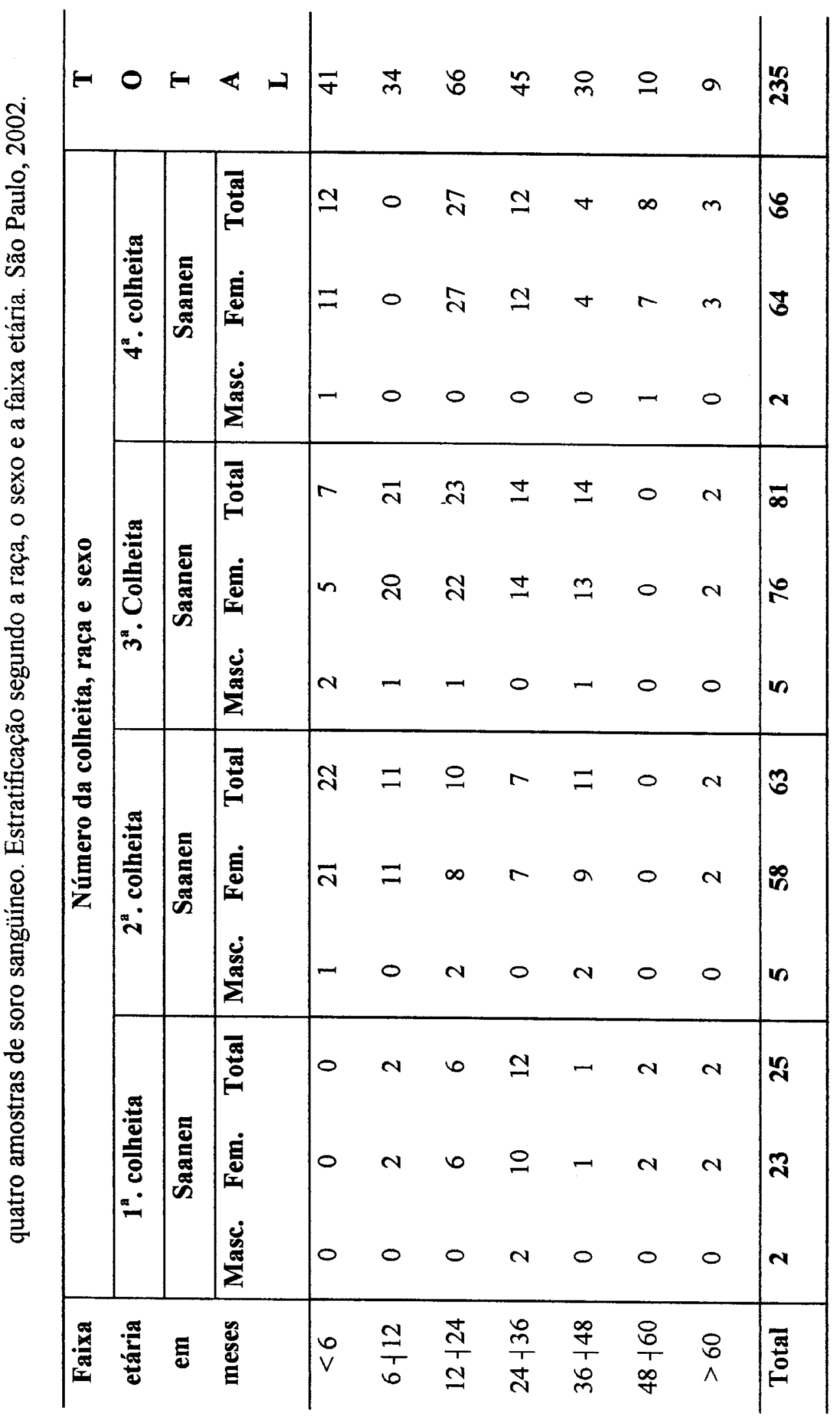




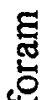

总

용 중

苞

.

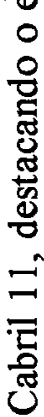

옴

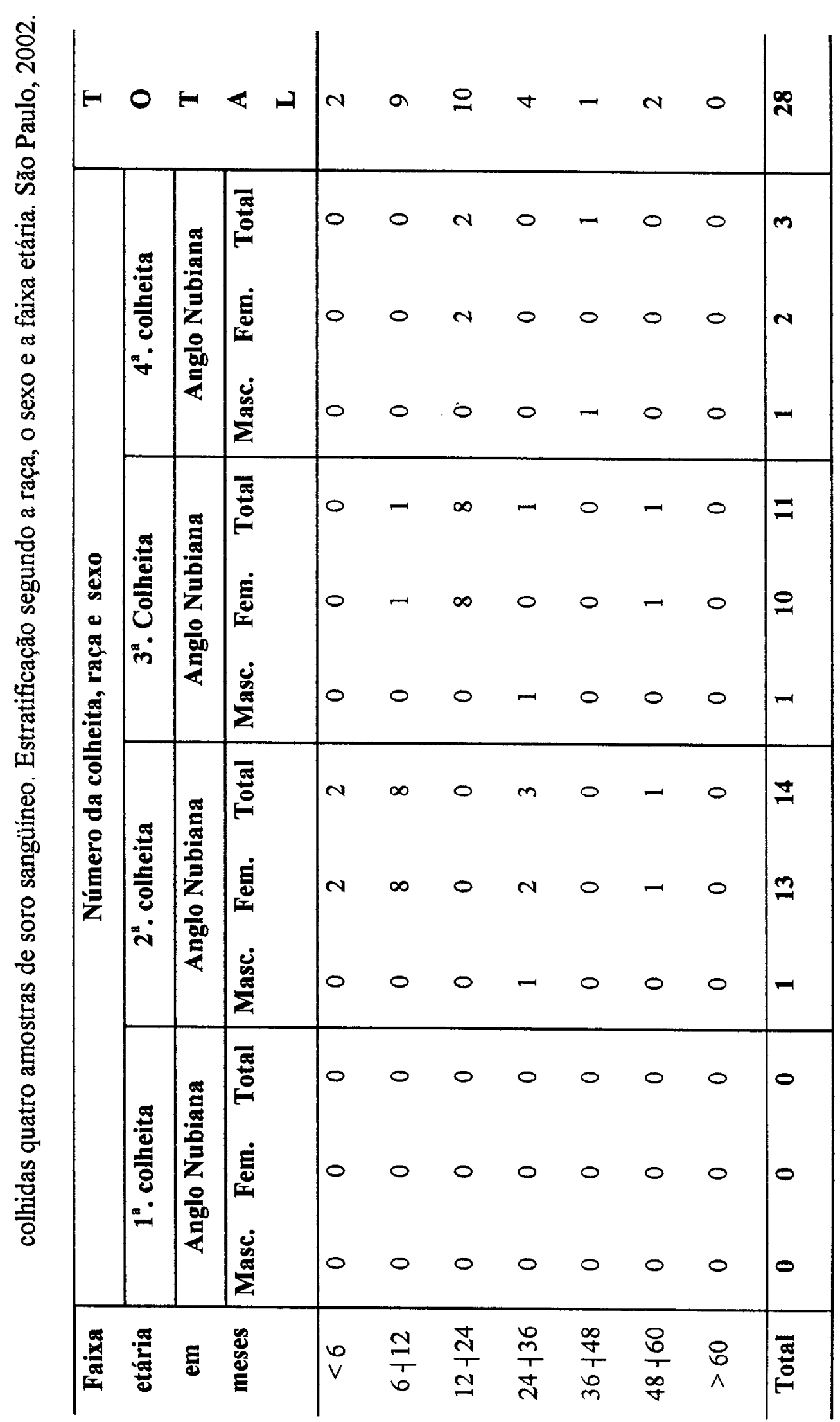


要

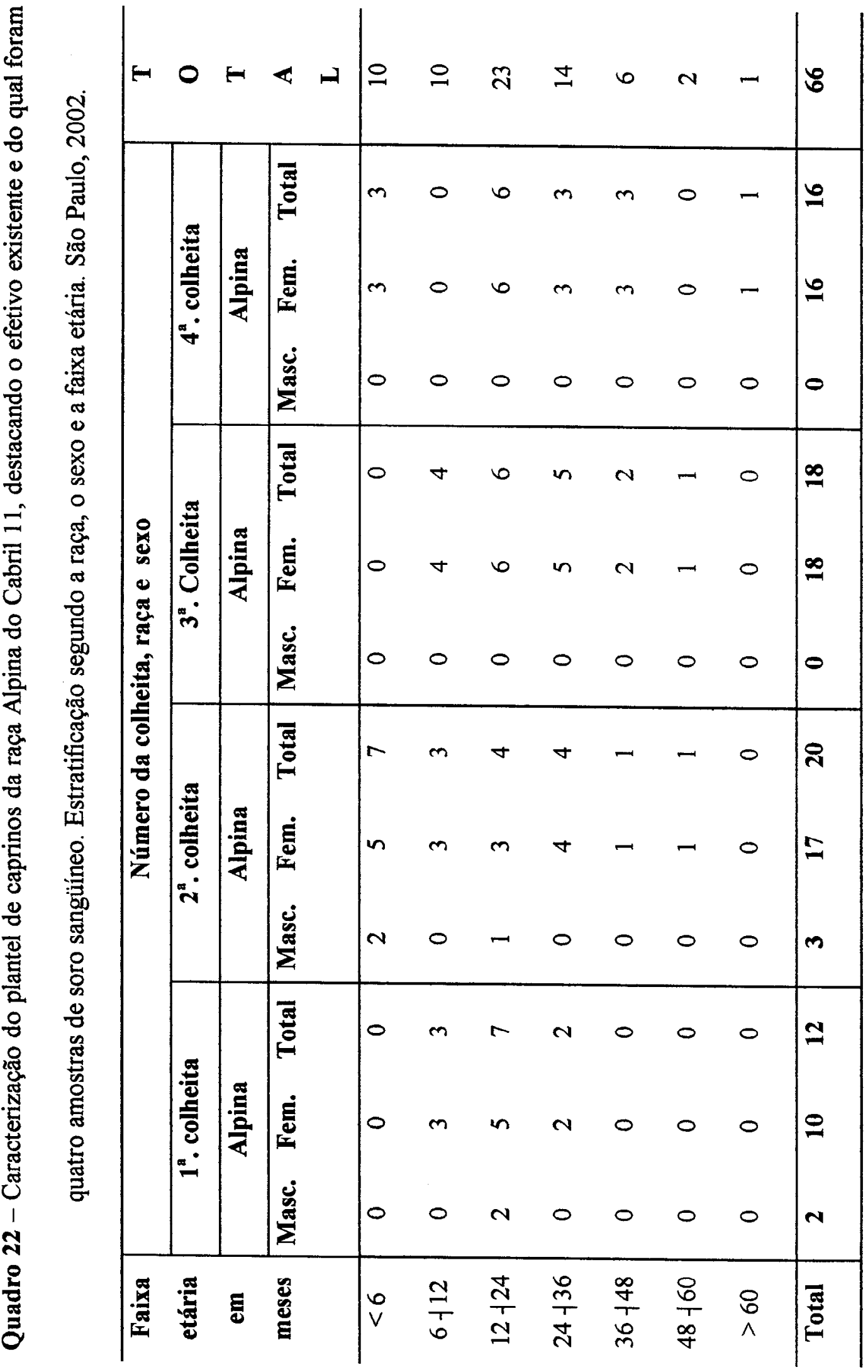


D

\begin{tabular}{|c|c|c|c|c|c|c|c|c|c|c|c|c|}
\hline$E$ & 0 & $E$ & $\varangle$ & $ـ$ & $r$ & 0 & $=$ & $\infty$ & $N$ & 0 & $\stackrel{ }{\circ}$ & 8 \\
\hline \multirow{4}{*}{ 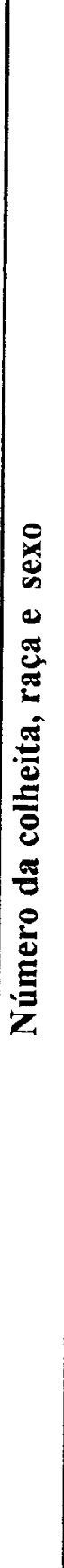 } & 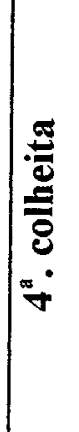 & 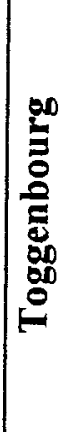 & 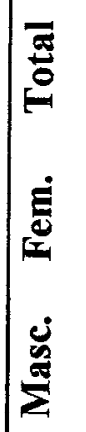 & & $\begin{array}{l}0 \\
0 \\
0\end{array}$ & $\begin{array}{l}0 \\
0\end{array}$ & $\begin{array}{l}N \\
N\end{array}$ & $\begin{array}{l}- \\
-\end{array}$ & $\begin{array}{l}0 \\
0\end{array}$ & $\begin{array}{l}0 \\
0\end{array}$ & $\begin{array}{l}m \\
m \\
0\end{array}$ & $\begin{array}{l}0 \\
0\end{array}$ \\
\hline & 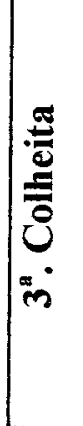 & 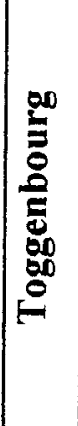 & 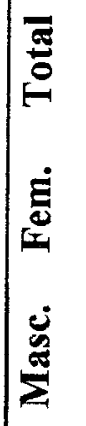 & & $\begin{array}{l}0 \\
\text { in }\end{array}$ & $\begin{array}{l}0 \\
0 \\
0\end{array}$ & - & $m$ & 0 & $\rightarrow$ & $N$ & $\begin{array}{l} \pm \\
= \\
\text { m }\end{array}$ \\
\hline & 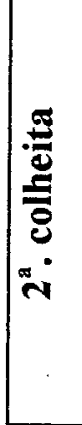 & 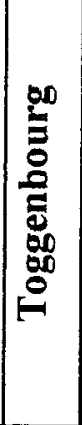 & 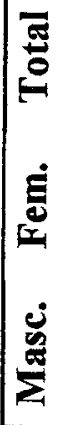 & & - & $\begin{array}{l}\nabla \\
\nabla\end{array}$ & $\begin{array}{l}N \\
N\end{array}$ & $\begin{array}{l}N \\
-\end{array}$ & 0 & - & $m$ & $\begin{array}{l} \pm \\
= \\
=\end{array}$ \\
\hline & 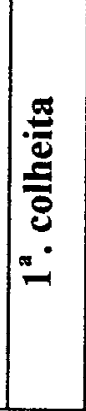 & 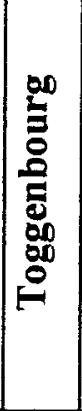 & 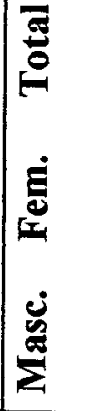 & & $\begin{array}{l}0 \\
0 \\
0\end{array}$ & $\begin{array}{l}N \\
0\end{array}$ & - & $\begin{array}{l}N \\
N\end{array}$ & $N$ & $\begin{array}{l}m \\
m\end{array}$ & $\begin{array}{l}N \\
N\end{array}$ & $\begin{array}{l}0 \\
\simeq\end{array}$ \\
\hline$\frac{\pi}{\pi}$ & & $\Xi$ & 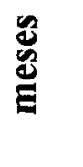 & & $\begin{array}{l}\sigma \\
\vee\end{array}$ & $\frac{\sim}{10}$ & $\begin{array}{l}\stackrel{+}{\sim} \\
\stackrel{\sim}{\sim}\end{array}$ & $\frac{0}{m}$ & 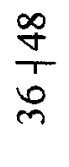 & $\begin{array}{l}8 \\
\frac{8}{0} \\
\stackrel{\infty}{+}\end{array}$ & $\begin{array}{l}8 \\
\wedge\end{array}$ & 馬 \\
\hline
\end{tabular}




\section{Cabril 12}

No décimo segundo plantel avaliado, localizado no município de Cotia, eram criados cerca de 66 caprinos, das raças Saanen (31), Alpina (5), Anglo Nubiana (27) eMestiços (3), em sistema de manejo intensivo, numa área de 6 hectares, dos quais foram colhidas 265 amostras de soro sangüíneo. As instalações eram do tipo galpão, com piso ripado esuspenso, sendo os animais mantidos em baias de $12 \mathrm{~m}^{2}$. As características específicas dos animais desse plantel, distribuídos segundo o sexo, a raça e a faixa etária foram transcritas nosQuadros 24, 25, 26 e 27. O manejo alimentar desses animais consistia na administração de raçãoconcentrada comercial. O sistema de ordenha era manual, com sala e plataforma de ordenha,sendo a produção média diária de leite igual a 2,4 litros por cabra. O aleitamento dos cabritoslactentes mantidos em aprisco coletivo era artificial e controlado, com uso de mamadeiras individuais; ao neonato, imediatamente após o nascimento, era administrado colostro e a seguir, os lactentes recebiam, em mamadeiras, o leite natural de cabra, não pasteurizado. Os equipamentos e utensílios utilizados, tanto para a ordenha como também para o aleitamentodos cabritos eram lavados com água e detergente. O controle clínico-sanitário era pouco intensoe esporádico, consistindo apenas em vermifugações a cada seis meses, sem controle coproparasitológico. Os instrumentos de uso clínico para o tratamento de animais enfermos - seringas e agulhas, não eram descartáveis. Como sistema de identificação, utilizavam-secoleiras com medalhas de metal e tatuagem, não sendo utilizado nenhum método de desinfecção do tatuador. Não era feita limpeza periódica dos galpões, baias e locais de permanência dos caprinos. O proprietário, ao falar dos antecedentes do rebanho, não relatou aocorrência de mamite, diarréia, pneumonia ou artrite dos caprinos. O sistema de manejo reprodutivo do rebanho, consistia na cobertura das matrizes por monte controlada ou por inseminação artificial. No Cabril 12, todos os animais foram examinados no momento da colheita das amostras e durante os dois anos em que durou a parte experimental desta teseforam realizadas quatro colheitas de sangue, para obtenção de soro sangüíneo. 


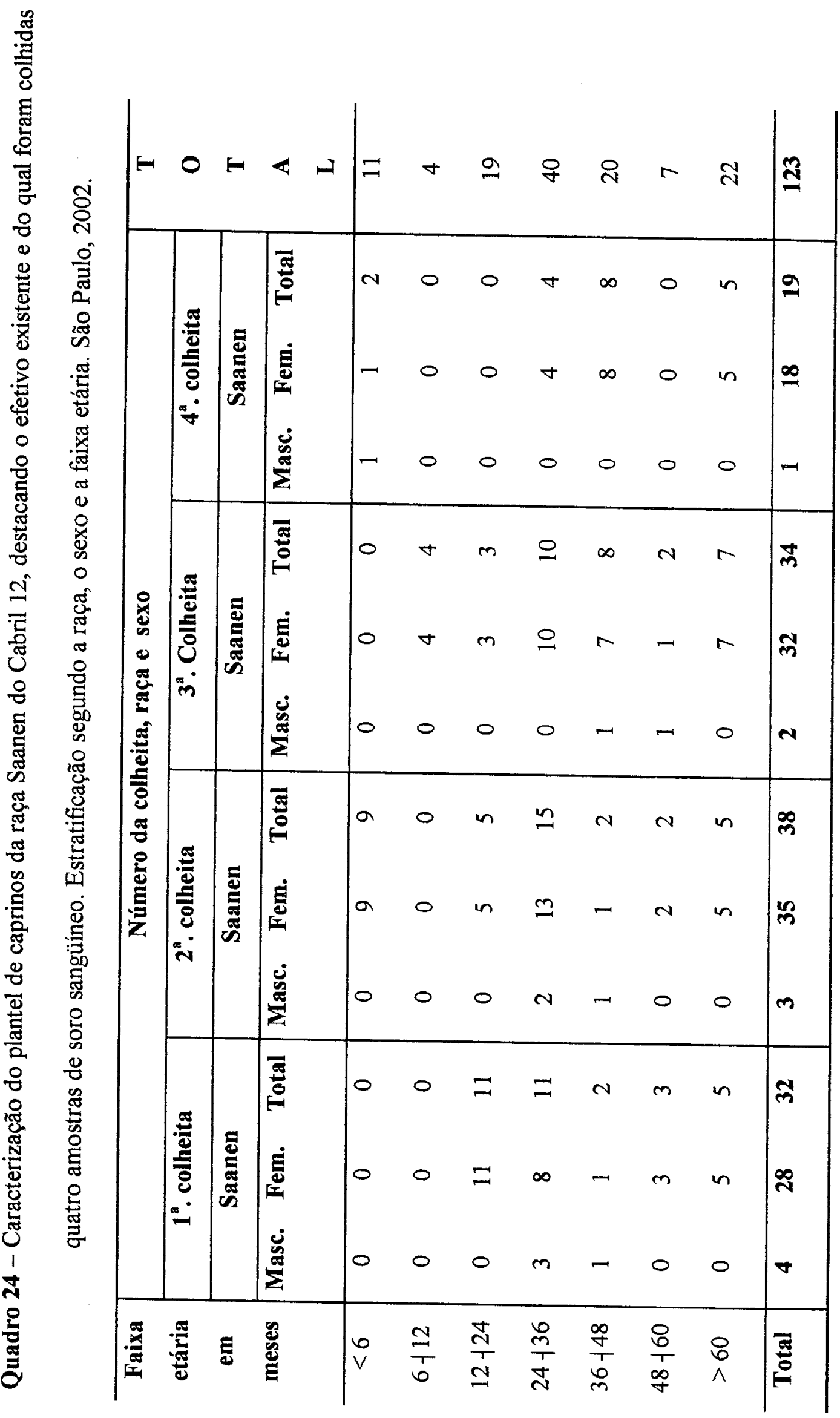




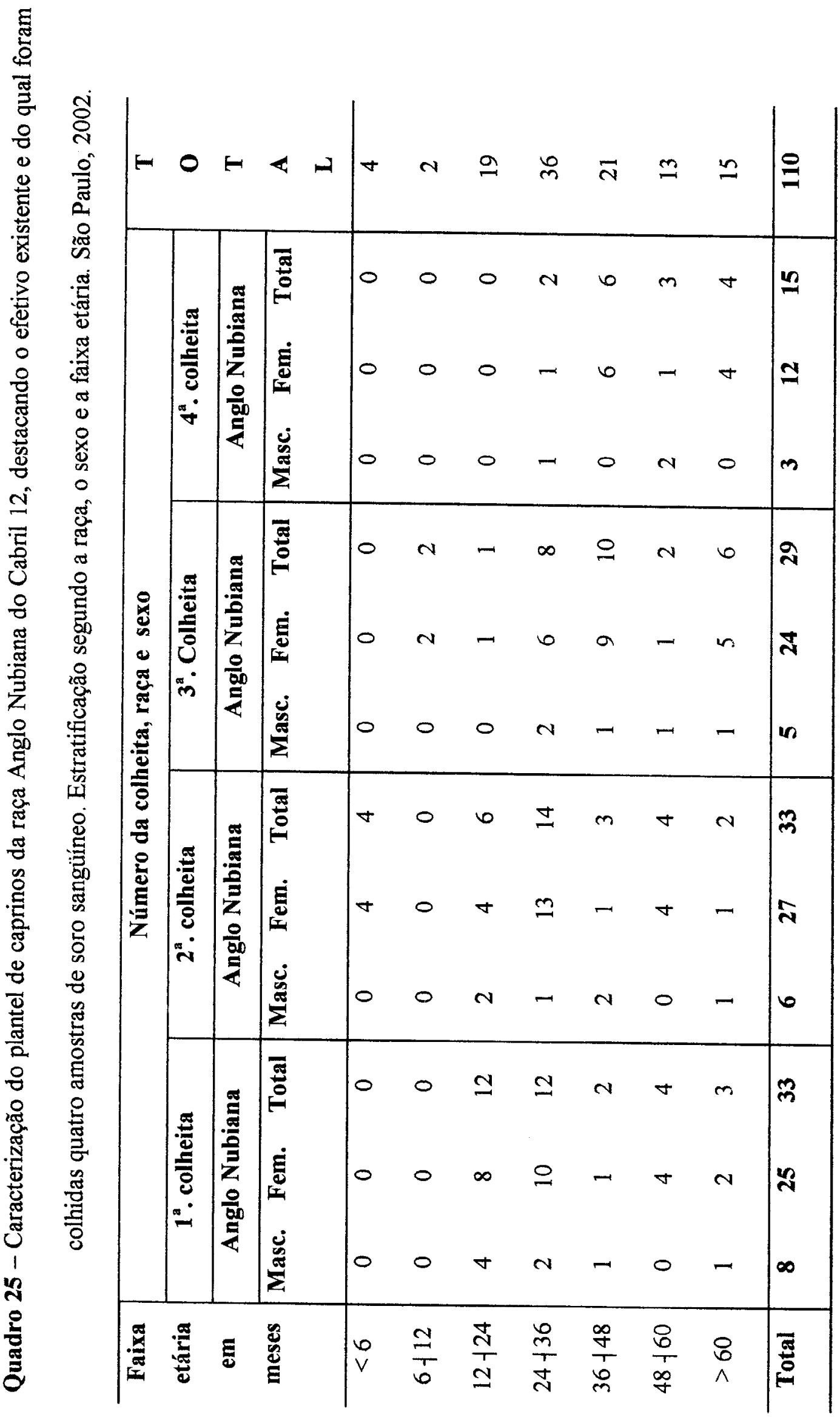


要

\begin{tabular}{|c|c|c|c|c|c|c|c|c|c|c|c|}
\hline$=c$ & $D E$ & 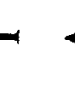 & $\varangle$ & - & 0 & $n$ & 0 & $n$ & $N$ & 0 & 12 \\
\hline \multirow{4}{*}{ 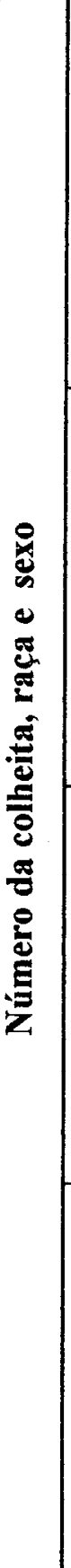 } & 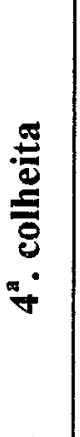 & 苟 & 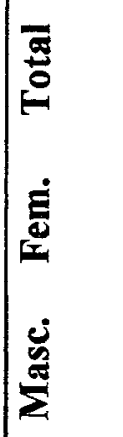 & $\begin{array}{l}0 \\
0\end{array}$ & $\begin{array}{l}0 \\
0 \\
0\end{array}$ & $\begin{array}{l}- \\
- \\
0\end{array}$ & $\begin{array}{l}0 \\
0\end{array}$ & $\begin{array}{l}0 \\
4 \\
n\end{array}$ & $\begin{array}{l}- \\
- \\
0\end{array}$ & 0 & $\int_{0}^{+}$ \\
\hline & 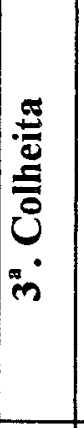 & 苟 & 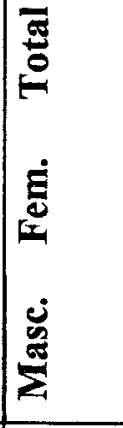 & 10 & $\begin{array}{l}0 \\
0 \\
0\end{array}$ & $\begin{array}{l}- \\
- \\
0\end{array}$ & 0 & $\begin{array}{l}- \\
- \\
0\end{array}$ & $\begin{array}{l}- \\
- \\
0\end{array}$ & 0 & in \\
\hline & & 嵒 & 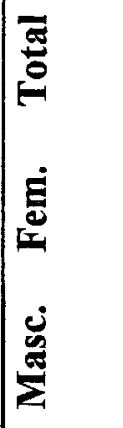 & - & $\begin{array}{l}0 \\
0 \\
0\end{array}$ & $\begin{array}{l}0 \\
0 \\
0\end{array}$ & m & $\begin{array}{l}- \\
- \\
0\end{array}$ & $\begin{array}{l}0 \\
0 \\
0\end{array}$ & 0 & $\int_{0}^{n}$ \\
\hline & 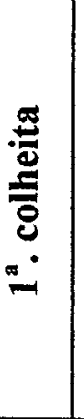 & $\frac{\pi}{3}$ & 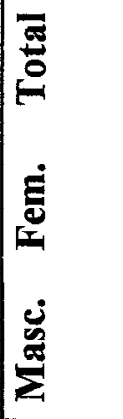 & 10 & $\begin{array}{l}0 \\
0 \\
0\end{array}$ & $\begin{array}{l}m \\
m \\
0\end{array}$ & - & $\begin{array}{l}- \\
- \\
0\end{array}$ & $\begin{array}{l}0 \\
0 \\
0\end{array}$ & 0 & $\int_{n}^{n}$ \\
\hline 离 & d & $\Xi$ & 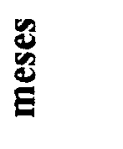 & $\begin{array}{l}0 \\
V\end{array}$ & $\frac{\cong}{7}$ & $\begin{array}{l}\stackrel{\sim}{\sim} \\
\stackrel{\sim}{\simeq}\end{array}$ & $\frac{\stackrel{D}{m}}{\stackrel{m}{+}}$ & $\frac{\infty}{+}$ & $\begin{array}{l}8 \\
\frac{8}{1} \\
\frac{\infty}{+}\end{array}$ & $\begin{array}{l}8 \\
\wedge\end{array}$ & 焉 \\
\hline
\end{tabular}




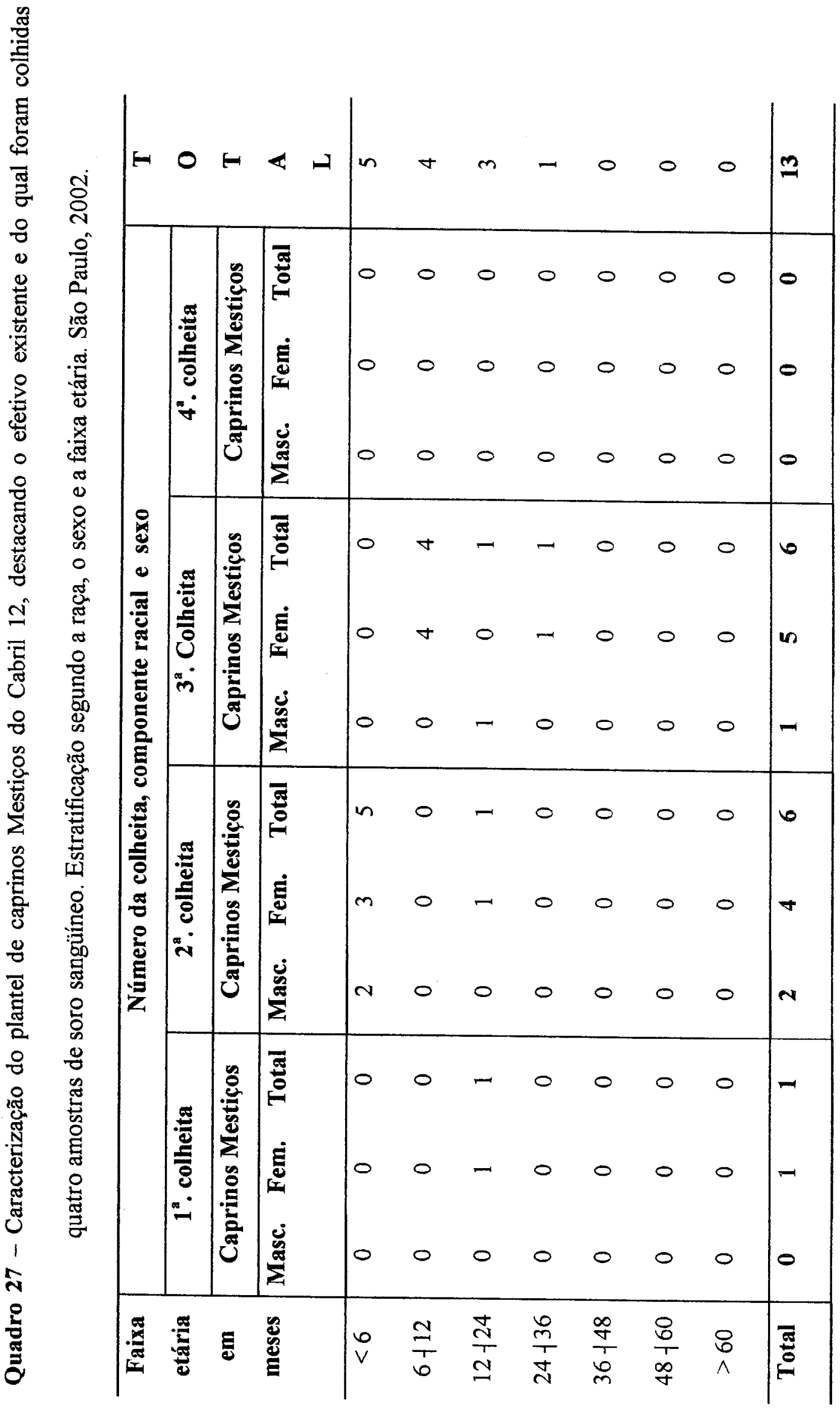




\section{Cabril 13}

O Cabril 13, com 65 hectares de área e localizado no município de BragançaPaulista era constituído, aproximadamente, por 112 caprinos, assim distribuídos: uma cabraMestiça com 8, 16, 22 e 28 meses de idade, respectivamente, na $1^{\mathrm{a}} ., 2^{\mathrm{a}} ., 3^{\mathrm{a}}$. e $4^{\mathrm{a}}$. colheitas; doisanimais da raça Alpina, sendo um bode, com 42, 50 e 56 meses de idade, na $1^{\mathrm{a}}$., $2^{\mathrm{a}}$. e $3^{\mathrm{a}}$. colheitas, respectivamente e uma cabrita com idade de 2 meses na $2^{\mathrm{a}}$. colheita e, em sua grande maioria,por caprinos das raças Saanen (cerca de 106 animais) e Bôer (6 caprinos); desses animais foramcolhidas 447 amostras de soro sangüíneo. Os animais pertencentes às raças Saanen e Bôer, agrupados quanto faixa etária e sexo, foram caracterizados nos Quadros 28 e 29. O manejo doplantel do Cabril 13 correspondia a um sistema intensivo de criação. As instalações eram dotipo galpão, com piso ripado e suspenso, contendo baias de área de $8 \mathrm{~m}_{2}$. A esses animais erafornecida ração concentrada comercial, associada a capim picado e sal mineral ad libitum. Este Cabril possuía sistema mecânico de ordenha, com sala e plataforma de ordenha. A produçãomédia diária de leite das cabras lactantes era de 3 litros por animal. Os utensílios da ordenhaeram lavados com água e detergente apropriado para uso em ordenhadeira mecânica. Os cabritos neonatos mamavam o colostro materno, logo após o nascimento e a seguir eram aleitados, mamando em suas mães, até a idade de 2 a 3 meses. O manejo clínico-sanitárioresumia-se apenas a vermifugações massais, a cada seis meses, sem orientação de exames coproparasitológicos. Os caprinos eram identificados por colares com medalhas metálicas, ondeconstavam o nome e número do animal e por tatuagem, mas não se realizava a desinfecção dotatuador, após seu uso. As seringas e agulhas utilizadas no tratamento de caprinos enfermoseram reutilizadas em outros animais. As baias e locais de permanência dos animais eram varridos para remoção mecânica dos detritos e periodicamente polvilhadas com cal virgem. Omanejo reprodutivo dos animais deste plantel obedecia as normas do sistema de cobertura commonta controlada. No período de duração da parte experimental desta tese, foram colhidasquatro amostras de soro sangüíneo de todos os animais do Cabril 13, após eles terem sido submetidos a exame físico. 


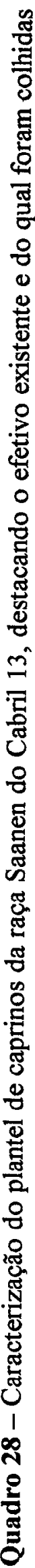

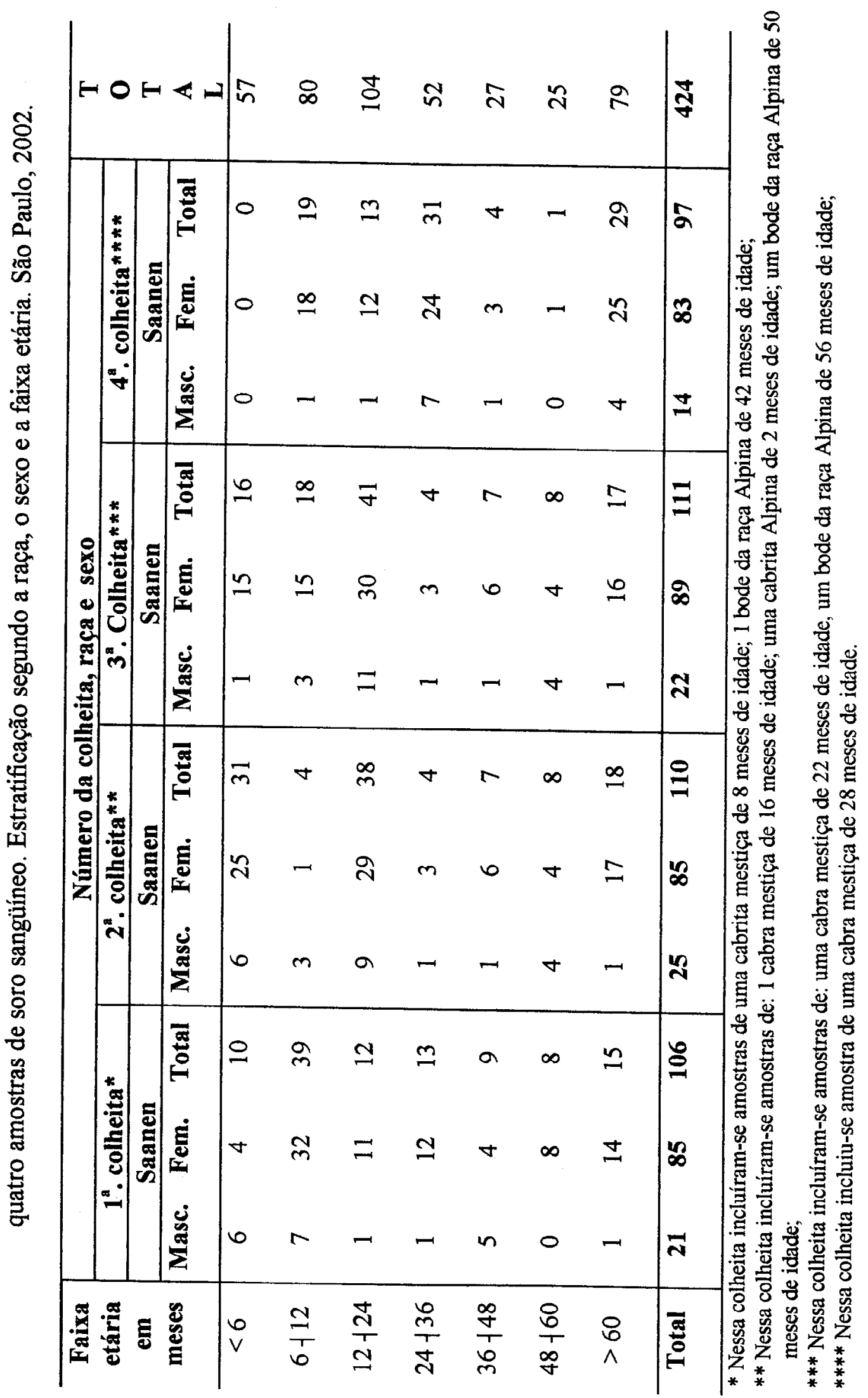




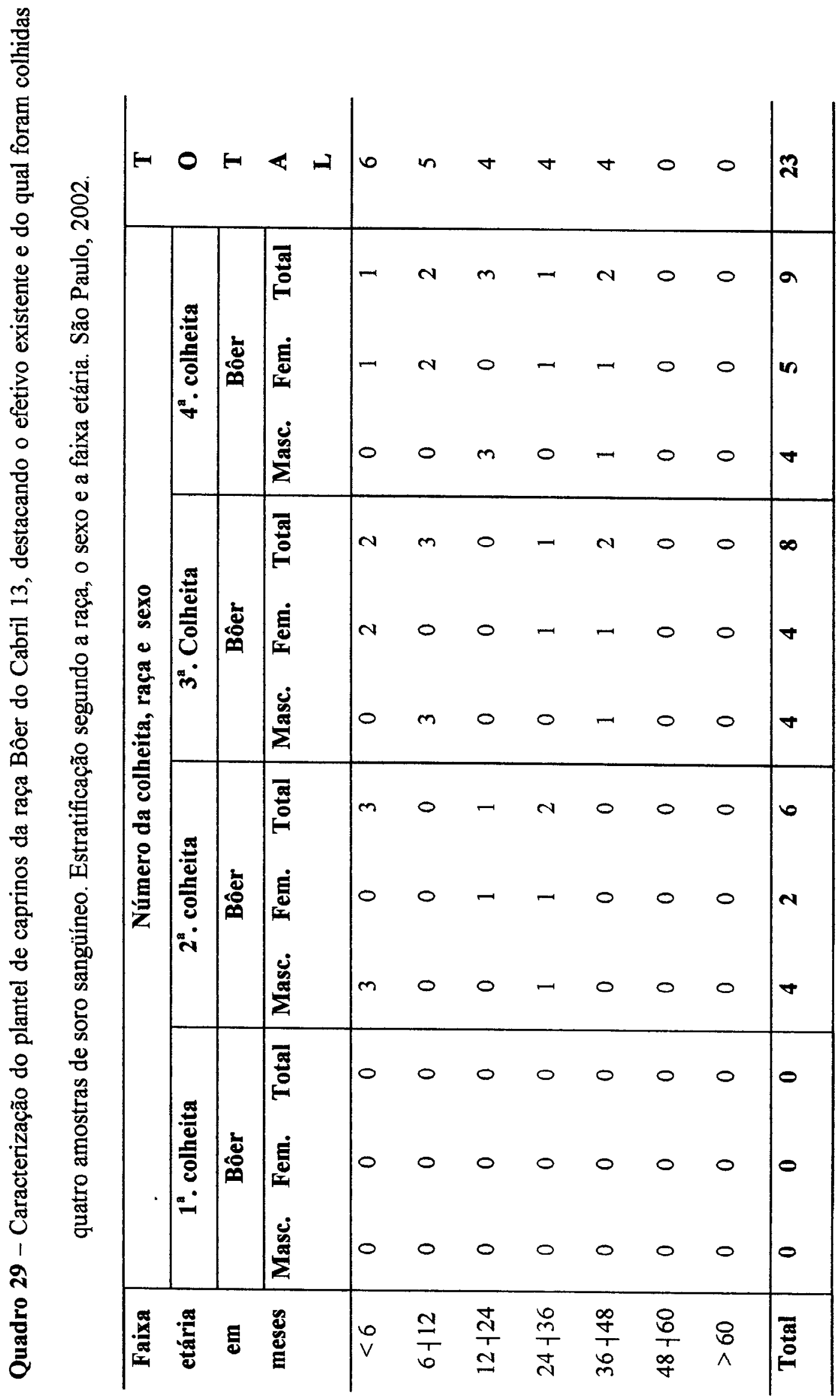




\section{Cabril 14}

Neste Cabril, localizado no município de Vargem, eram criados aproximadamente 29 caprinos da raça Saanen, em sistema intensivo, numa área de 15 hectares,dos quais foram colhidas 116 amostras de soro sangüíneo. As instalações eram do tipo galpão,com piso ripado e suspenso, dividido em baias de 4 e $12 \mathrm{~m}^{2}$. No manejo alimentar aplicado aosefetivos deste plantel, era fornecida ração concentrada comercial, associado à distribuição decapim picado e sal mineral ad libitum, para todos os caprinos do rebanho. A produção médiadiária de leite era de um litro por cabra, em sistema de ordenha manual, cujas instalaçõestinham sala e plataforma de ordenha; apesar dos funcionários não trabalharem uniformizados,estavam orientados a aplicarem os cuidados exigidos para produção higiênica de leite: lavageme secagem do úbere antes da ordenha, mas não se fazia a proteção dos tetos com soluções anti-sépticas, na fase da pós-ordenha. O aleitamento dos cabritos era natural, isto é, ingestão decolostro e aleitamento mamando na própria mãe. O controle sanitário era feito por vermifugação sem periodicidade definida e o reconhecimento dos animais infectados pelo vírusda Artrite-encefalite dos caprinos por exames imuno-sorológicos, após os quais chegou-se adescartar alguns caprinos sororeagentes positivos, sendo no tratamento dos animais enfermosutilizados seringas e agulhas descartáveis. O sistema de identificação utilizado para reconhecimento dos animais do plantel era o da colocação coleiras com medalhas, onde seinscreviam o nome e o número do caprinos, e o de tatuagem, que no decorrer da pesquisadeixou de ser utilizado. As baias eram limpas uma vez por ano com remoção mecânica dosdetritos, seguida da aplicação de "vassoura de fogo" e polvilhamento de cal virgem. O proprietário, no levantamento do histórico do plantel, não relatou a ocorrência de mamite, dediarréia, de pneumonias ou de artrite no rebanho. Além do mais, destacou-se que o manejoreprodutivo do plantel era feito segundo normas do sistema de cobertura por monta controlada. No Cabril 14, foram colhidas quatro amostras de todos os animais presentes norebanho, nos 2 anos de duração da parte experimental desta tese. As características dos caprinosque compunham o rebanho do Cabril 14, distribuídas segundo o sexo e faixa etária dos animais foram detalhadas no Quadro 30. 


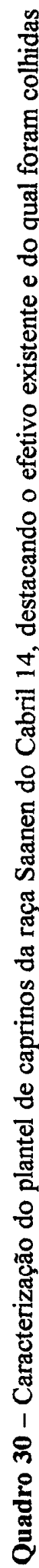

\begin{tabular}{|c|c|c|c|c|c|c|c|c|c|c|c|}
\hline$H$ & 0 & $F$ & 4 & \pm & $a$ & $\Xi$ & 0 & 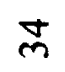 & $\stackrel{\sim}{\sim}$ & 2 & 을 \\
\hline \multirow{4}{*}{ 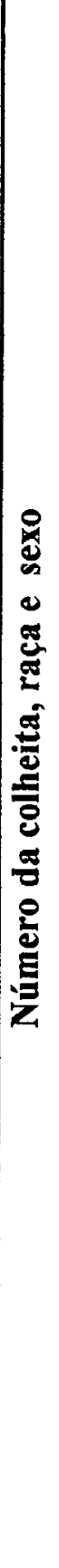 } & 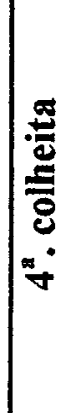 & 导 & 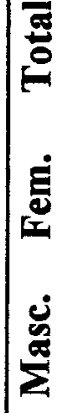 & $\int_{0}^{\pi}$ & $\begin{array}{l}0 \\
m \\
m\end{array}$ & $\begin{array}{l}N \\
N\end{array}$ & $\begin{array}{l}0 \\
0\end{array}$ & $\begin{array}{l}- \\
-\end{array}$ & 6 & $\begin{array}{l}- \\
r\end{array}$ & $\begin{array}{l}\bar{m} \\
\tilde{A}\end{array}$ \\
\hline & 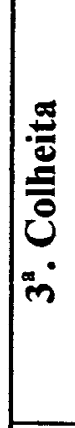 & 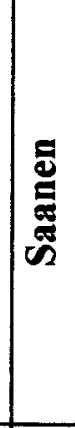 & 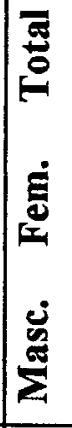 & $\begin{array}{l}0 \\
m \\
m\end{array}$ & $\begin{array}{l}0 \\
0 \\
0\end{array}$ & $\begin{array}{l}n \\
N\end{array}$ & 0 & - & $\simeq$ & $m$ & సิ \\
\hline & ن & 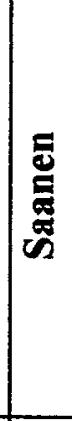 & 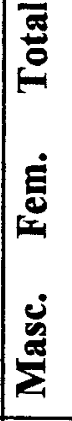 & $\begin{array}{l}\sigma \\
0\end{array}$ & $\begin{array}{l}m \\
N\end{array}$ & $\begin{array}{l}0 \\
0\end{array}$ & - & $a$ & $r$ & - & 2 \\
\hline & 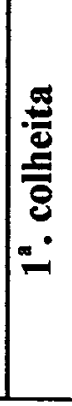 & 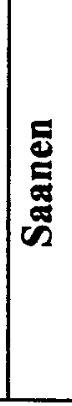 & 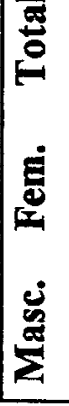 & $\begin{array}{l}0 \\
0 \\
0\end{array}$ & $\begin{array}{l}0 \\
0\end{array}$ & $\begin{array}{l}0 \\
0\end{array}$ & $\begin{array}{l}n \\
n\end{array}$ & $\tilde{\mathrm{N}}$ & - & $N$ & $\begin{array}{l}\bar{m} \\
\text { à }\end{array}$ \\
\hline$\underset{\pi}{\pi}$ & & E్ & 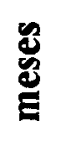 & 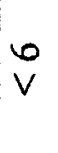 & $\frac{N}{1}$ & $\frac{\stackrel{+}{N}}{\stackrel{N}{N}}$ & $\frac{\stackrel{0}{m}}{\underset{\sim}{+}}$ & $\frac{\infty}{\stackrel{\infty}{+}}$ & $\begin{array}{l}\stackrel{8}{0} \\
\stackrel{\infty}{\infty} \\
\stackrel{+}{+}\end{array}$ & $\begin{array}{l}8 \\
\wedge\end{array}$ & 要 \\
\hline
\end{tabular}




\subsection{Formação dos Grupos Experimentais}

Para alcançar adequadamente os objetivos do delineamento proposto para esta pesquisa, omaterial colhido dos animais que compuseram a população avaliada nos 14 Cabris estudados foram redistribuídos emvários grupos experimentais, a seguir detalhados.

\subsubsection{Determinação da freqüência de anticorpos antivírus da Artrite-encefalite dosCaprinos em plantéis de caprinos criados em São Paulo .}

A avaliação da prevalência de anticorpos antivírus da Artrite-encefalite dos Caprinos, emamostras de soro sangüíneo de animais da espécie Capra hircus, no período de dois anos de duração desta pesquisa - 2000-2001, criados em 14 Cabris do Estado de São Paulo, baseou-se no acompanhamento, no referido período, de 820caprinos e, em 3.280 provas imuno-sorológicas realizadas. As características dos plantéis e da amostragem foramdetalhadas nos quadros 4 a 30 .

Para a avaliação da taxa de prevalência de anticorpos antivírus da Artrite-encefalite dosCaprinos nos 14 plantéis criados em São Paulo, a população de animais que constituíram a amostragem experimentaldesta tese foi redistribuída, para que os caprinos do fato de cada um desses Cabris fosse considerado um grupo dedelineamento experimental. Nesses grupos foram incluídos todos os animais, dos quais colheram-se amostras, intervaladas por seis meses, durante o biênio 2000-2001. Os grupos foram estratificados considerando-se apenas onúmero médio de caprinos criados no cabril, no mencionado.período, o número de amostras de soro sangüíneo 
colhidas em cada um dos momentos de avaliação dos animais, bem como o número total de amostras colhidas. Ressalte-se que as demais variáveis passíveis de análise não foram consideradas. A caracterização dos grupos utilizados para avaliar a freqüência da ocorrência da infecção em cada um dos cabris e evidenciação do número de cabris infectados e/ou não infectados, foi detalhada na Tabela 2.

Tabela 2 - Caracterização do plantel de caprinos dos 14 Cabris utilizados para determinação da magnitude da prevalência da infecção pelo vírus da Artrite-encefalite dos Caprinos no Estado de São Paulo, no período de 2000-2001. São Paulo, 2002.

\begin{tabular}{c|c|c|c|c|c|c}
\hline \multirow{2}{*}{ Cabril } & Número Médio & \multicolumn{5}{|c}{ Número de amostras colhidas -2000-2001 } \\
\cline { 3 - 7 } & de Caprinos & $\mathbf{1}^{\mathbf{2}}$. colheita & $\mathbf{2}^{\mathbf{2}}$. colheita & $\mathbf{3}^{\mathbf{2}}$. colheita & $\mathbf{4}^{\mathbf{2}}$. colheita & Total \\
\hline 1 & 22 & 18 & 18 & 29 & 25 & 90 \\
2 & 24 & 24 & 20 & 26 & 26 & 96 \\
3 & 145 & 134 & 150 & 138 & 157 & 579 \\
4 & 36 & 33 & 34 & 40 & 39 & 146 \\
5 & 53 & 39 & 45 & 55 & 74 & 213 \\
6 & 65 & 64 & 56 & 61 & 79 & 260 \\
7 & 39 & 28 & 43 & 41 & 42 & 154 \\
8 & 82 & 94 & 86 & 79 & 71 & 330 \\
9 & 18 & 20 & 16 & 20 & 15 & 71 \\
10 & 34 & 36 & 33 & 36 & 29 & 134 \\
11 & 95 & 53 & 111 & 124 & 91 & 379 \\
12 & 66 & 71 & 82 & 74 & 38 & 265 \\
13 & 112 & 106 & 116 & 119 & 106 & 447 \\
14 & 29 & 31 & 25 & 29 & 31 & 116 \\
\hline Total & $\mathbf{8 2 0}$ & $\mathbf{7 5 1}$ & $\mathbf{8 3 5}$ & $\mathbf{8 7 1}$ & $\mathbf{8 2 3}$ & $\mathbf{3 . 2 8 0}$ \\
\hline
\end{tabular}

3.2.2 Determinação da taxa de incidência da infecção pelo vírus da Artriteencefalite dos Caprinos, nos 14 Cabris considerados nesta pesquisa.

A determinação da taxa de incidência da infecção pelo vírus da Artrite-encefalite dos Caprinos foi verificada pela avaliação da freqüência de 
caprinos, nos quais demonstrou-se soroconversão, isto é, quando animais sadios e que, num período de seis meses, tornaram-se sororeagentes positivos aos antígenos do vírus da $\mathrm{AEC}$, nos quatro diferentes momentos de colheita das amostras de soro sangüíneo, o que foi detalhado na Tabela 3. Neste ponto, julgou-se necessário, para fins de elucidação, reafirmar que durante os dois anos de duração da pesquisa, com intervalos regulares de seis meses, foram colhidas quatro amostras de soro sangüíneo de todos os animais incluídos na população experimental. Tais avaliações foram feitas nos 14 plantéis inseridos nesta pesquisa, como detalhado nos Quadros de números 4 a 30 .

Tabela 3 - Caracterização do plantel de caprinos dos 14 Cabris utilizados para determinação da taxa de incidência da infecção pelo vírus da Artriteencefalite dos Caprinos no Estado de São Paulo, no período de 20002001. São Paulo, 2002.

\begin{tabular}{|c|c|c|c|c|c|}
\hline \multirow{3}{*}{ Cabril } & \multicolumn{5}{|c|}{ Número de amostras colhidas $-2000-2001$} \\
\hline & \multirow{2}{*}{$\begin{array}{l}\text { Prevalência } \\
1^{n} \text {. colheita }\end{array}$} & \multicolumn{3}{|c|}{ Incidência } & \multirow[t]{2}{*}{ Total } \\
\hline & & $2^{2}$. colheita & $3^{a}$. colheita & $4^{2}$. colheita & \\
\hline 1 & 18 & 18 & 29 & 25 & 90 \\
\hline 2 & 24 & 20 & 26 & 26 & 96 \\
\hline 3 & 134 & 150 & 138 & 157 & 579 \\
\hline 4 & 33 & 34 & 40 & 39 & 146 \\
\hline 5 & 39 & 44 & 51 & 68 & 202 \\
\hline 6 & 64 & 55 & 61 & 77 & 257 \\
\hline 7 & 28 & 41 & 37 & 37 & 143 \\
\hline 8 & 94 & 86 & 79 & 71 & 330 \\
\hline 9 & 20 & 16 & 20 & 15 & 71 \\
\hline 10 & 36 & 25 & 29 & 21 & 111 \\
\hline 11 & 53 & 87 & 71 & 55 & 266 \\
\hline 12 & 71 & 42 & 29 & 10 & 152 \\
\hline 13 & 106 & 73 & 55 & 45 & 279 \\
\hline 14 & 31 & 11 & 16 & 20 & 78 \\
\hline Total & 751 & 702 & 681 & 666 & 2.800 \\
\hline
\end{tabular}




\subsubsection{Freqüência da ocorrência de anticorpos antivírus da Artrite-encefalite dos} Caprinos, em animais de 6 grupos raciais: Saanen; Alpina; Anglo Nubiana; Toggenbourg; Bôer e caprinos mestiços. Avaliação da influência de fatores raciais.

Para avaliação da influência de fatores raciais sobre a freqüência de caprinos sororeagentes aos antígenos do vírus da Artrite-encefalite dos Caprinos, a população de caprinos, pertencente aos 14 Cabris incluídos nesta pesquisa relativa a ocorrência da virose causada pelo já mencionado vírus, circunscritos em 14 municípios do Estado de São Paulo, foi redistribuída em seis grupos formados por animais das raças Saanen; Alpina; Anglo Nubiana; Toggenbourg; Bôer e animais mestiços. Esses grupos foram estratificados segundo as 6 raças predominantes no Estado de São Paulo, o número médio desses caprinos criados nos 14 cabris, bem como pelos números parciais e totais de amostras consideradas nas 4 colheitas de sangue realizadas. A caracterização dos grupos foi detalhada na Tabela 4.

Tabela 4 - Caracterização dos grupos raciais utilizados para a avaliação da prevalência e incidência de anticorpos antivírus da Artrite-encefalite dos Caprinos, no período de 2000-2001. São Paulo, 2002.

\begin{tabular}{|c|c|c|c|c|c|c|}
\hline $\begin{array}{l}\text { Grupos } \\
\text { Raciais } \\
\end{array}$ & $\begin{array}{c}\text { Número de } \\
\text { Caprinos }\end{array}$ & $\begin{array}{c}12 . \\
\text { colheita }\end{array}$ & $\begin{array}{c}2^{2} \\
\text { colheita }\end{array}$ & $\begin{array}{c}3^{a} . \\
\text { colheita }\end{array}$ & $\begin{array}{c}4^{\mathrm{a}} \\
\text { colheita }\end{array}$ & TOTAL \\
\hline Saanen & 614 & 562 & 612 & 650 & 634 & 2.458 \\
\hline Alpina & 124 & 109 & 125 & 132 & 131 & 497 \\
\hline Anglo Nubiana & 34 & 33 & 47 & 40 & 18 & 138 \\
\hline Toggenbourg & 13 & 16 & 14 & 14 & 6 & 50 \\
\hline Bôer & 9 & 1 & 7 & 11 & 15 & 34 \\
\hline Mesticos & 26 & 30 & 30 & 24 & 19 & 103 \\
\hline Total & 820 & 751 & 835 & 871 & 823 & 3.280 \\
\hline
\end{tabular}




\subsubsection{Freqüência da ocorrência de anticorpos antivírus da Artrite-encefalite dosCaprinos em animais dos sexos masculino e feminino. Avaliação da influência de fatores sexuais.}

Para a avaliação da influência de fatores sexuais sobre a freqüênciade caprinos infectados pelo vírus da Artrite-encefalite dos Caprinos, os animais criados nos 14 Cabris definidos nesta pesquisa com mais de 8 meses de idade - sexualmente ativos, foram estratificados, em dois subgrupos: um constituído por 74bodes e outro por 594 cabras, totalizando 668 animais, dos quais colheram-se, no período 2000-2001, respectivamente 291; 2.375 e 2.666 amostras de soro sangüíneopara determinação da infecção pelo vírus da Artrite-encefalite dos Caprinos. Os 668 caprinos que serviram para avaliação da influência dos fatores sexuais sobre a ocorrência da infecção pelo vírus da AEC eram de diferentes grupos raciais: 499 Saanen (54 machos e 445 fêmeas), dos quais colheram-se 1.996 amostras de soro(216 amostras dos machos e 1.780 das fêmeas); 97 da raça Alpina (8 machos e 89fêmeas), dos quais colheram-se 387 amostras de soro sangüíneo (31 dos machos e356 das fêmeas); 33 Anglo Nubianos (6 machos e 27 fêmeas) dos quais colheram-se132 amostras (25 dos machos e 107 das fêmeas); 11 da raça Toggenbourg (2 machose 9 fêmeas), dos quais colheram-se 42 amostras de sangue (5 dos machos e 37 dasfêmeas); 6 caprinos da raça Bôer (3 machos e 3 fêmeas), dos quais foram colhidas 23 amostras de soro sangüíneo (13 dos machos e 10 das fêmeas) e finalmente, 22 caprinos mestiços (1 macho e 21 fêmeas), dos quais colheram-se 86 amostras desangue (1 do macho e 85 das fêmeas). A caracterização do grupo experimental para 
avaliação da influência dos fatores sexuais sobre a freqüência da infecção pelo vírus da Artrite-encefalite dos Caprinos foi detalhada nas Tabelas 5 e 6.

Tabela 5 - Distribuição dos caprinos dos plantéis dos 14 Cabris, segundo o número de machos e fềmeas púberes. Destaque para os números de animais e de amostras colhidas no período de 2000-2001. São Paulo, 2002.

\begin{tabular}{cccc|ccc}
\hline & \multicolumn{3}{c|}{ Número de Caprinos } & \multicolumn{3}{c}{ Número de Amostras } \\
\cline { 2 - 7 } Cabril & Machos & Fêmeas & Total & Machos & Fêmeas & Total \\
\hline 1 & 2 & 15 & 17 & 6 & 58 & 64 \\
2 & 1 & 19 & 20 & 3 & 74 & 77 \\
3 & 3 & 114 & 117 & 10 & 456 & 466 \\
4 & 2 & 28 & 30 & 6 & 113 & 119 \\
5 & 3 & 36 & 39 & 12 & 145 & 157 \\
6 & 4 & 44 & 48 & 16 & 175 & 191 \\
7 & 2 & 26 & 28 & 9 & 103 & 112 \\
8 & 8 & 66 & 74 & 32 & 266 & 298 \\
9 & 2 & 13 & 15 & 8 & 54 & 62 \\
10 & 10 & 17 & 27 & 40 & 69 & 109 \\
11 & 5 & 68 & $\mathbf{7 3}$ & 20 & 273 & 293 \\
12 & 8 & 53 & 61 & 32 & 211 & 243 \\
13 & 19 & 75 & 94 & 78 & 299 & 377 \\
14 & 5 & 20 & 25 & 19 & 79 & 98 \\
\hline Total & $\mathbf{7 4}$ & $\mathbf{5 9 4}$ & $\mathbf{6 6 8}$ & $\mathbf{2 9 1}$ & $\mathbf{2 . 3 7 5}$ & $\mathbf{2 . 6 6 6}$ \\
\hline
\end{tabular}

Tabela 6 - Distribuição dos caprinos nos plantéis dos 14 Cabris, segundo o número de machos e fềmeas púberes e as raças dos animais. Destaque para os números de animais e de amostras colhidas no período de 2000-2001. São Paulo, 2002.

\begin{tabular}{l|ccc|ccc}
\hline \multirow{2}{*}{\multicolumn{1}{c|}{ Raças }} & \multicolumn{3}{c|}{ Número de Caprinos } & \multicolumn{3}{c}{ Número de Amostras } \\
\cline { 2 - 7 } & Machos & Fêmeas & Total & Machos & Fêmeas & Total \\
\hline Saanen & 54 & 445 & 499 & 216 & 1.780 & 1.996 \\
Alpina & 8 & 89 & 97 & 31 & 356 & 387 \\
Anglo Nubiana & 6 & 27 & 33 & 25 & 107 & 132 \\
Toggenbourg & 2 & 9 & 11 & 5 & 37 & 42 \\
Bôer & 3 & 3 & 6 & 13 & 10 & 23 \\
Mestiços & 1 & 21 & 22 & 1 & $\mathbf{8 5}$ & 86 \\
\hline \multicolumn{1}{c}{ Total } & $\mathbf{7 4}$ & $\mathbf{5 9 4}$ & $\mathbf{6 6 8}$ & $\mathbf{2 9 1}$ & $\mathbf{2 . 3 7 5}$ & $\mathbf{2 . 6 6 6}$ \\
\hline
\end{tabular}




\subsubsection{Freqüência da ocorrência de anticorpos antivírus da Artrite-encefalite dosCaprinos durante o desenvolvimento etário. Avaliação da influência de fatores etários.}

Para avaliar a influência de fatores etários sobre a freqüência de anticorposséricos antivírus da Artrite-encefalite dos Caprinos os animais criados nos fatos dos 14 Cabris, incluídos nesta pesquisa, como definidos nos Quadros de números 4 a 30,foram estratificados em sete faixas etárias. Cada uma delas representando um grupoexperimental, constituídos da seguinte forma: Grupo I, formado por 121 cabritoscom até seis meses de idade, dos quais, nas quatro colheitas semestrais - no período2000-2001, colheram-se 485 amostras de soro sangüíneo; Grupo II, constituído por120 cabritos com idades variando de 6 a 12 meses de idade, dos quais colheram-se481 amostras de soro sangüíneo; Grupo III, composto por 196 animais com idadesvariando entre 12 e 24 meses, dos quais foram colhidas 782 amostras; Grupo IV,formado por 141 caprinos cuja idade variava de 24 a 36 meses, sendo deles colhidas562 amostras de soro sangüíneo; $\quad$ Grupo $\quad$ V, composto por 94 animais com idadesvariando entre 36 a 48 meses, colhendo-se deles 376 amostras; Grupo VI, compostopor 64 caprinos com idade oscilando de 48 a 60 meses, dos quais foram colhidas 257amostras de sangue para obtenção de soro; e, Grupo VII formado por 84 caprinoscom mais de 60 meses de idade, colhendo-se deles 337 amostras de soro sangüíneo. Da população considerada nos 14 Cabris, utilizaram-se, para avaliação da influência dos fatores etários sobre a freqüência de caprinos infectados pelo vírus daArtrite-encefalite dos Caprinos, 3.280 amostras de soro sangüíneo, 
colhidas de 820 animais. Essas amostras distribuídas nos quatro momentos de colheita, no período 2000-2001, foram numericamente de: 751 amostras na primeira colheita; 835 amostras na segunda colheita; 871 amostras na terceira colheita e 823 amostras na quarta colheita. Os sete grupos experimentais foram caracterizados na Tabela 7. Para melhor detalhamento do material utilizado nesta avaliação, na Tabela 8, os animais foram distribuídos segundo a raça e as faixas etárias, ressaltando o número de caprinos e o número de amostras colhidas.

Tabela 7 - Distribuição dos caprinos dos 14 Cabris. Estratificação segundo as faixas etárias. Destaque para o número médio de caprinos nos plantéis e número amostras colhidas no período de 2000-2001. São Paulo, 2002.

\begin{tabular}{|c|c|c|c|c|c|c|c|}
\hline \multirow[t]{2}{*}{ Grupos } & \multirow{2}{*}{$\begin{array}{c}\text { Faixa etária } \\
\text { em meses }\end{array}$} & \multirow{2}{*}{$\begin{array}{c}N^{0} \cdot \text { médio de } \\
\text { caprinos }\end{array}$} & \multicolumn{5}{|c|}{ Número de amostras colhidas $-2000 / 2001$} \\
\hline & & & $\begin{array}{c}1^{2} \\
\text { colheita }\end{array}$ & $\begin{array}{c}2^{2} \\
\text { colheita }\end{array}$ & $\begin{array}{c}3^{a} \\
\text { colheita }\end{array}$ & $\begin{array}{c}4^{\mathrm{a}} \\
\text { colheita }\end{array}$ & Total \\
\hline $\mathbf{I}$ & $<6$ & 121 & 59 & 158 & 147 & 121 & 485 \\
\hline II & $6 \dashv 12$ & 120 & 156 & 76 & 151 & 98 & 481 \\
\hline III & $12 \nmid 24$ & 196 & 168 & 203 & 209 & 202 & 782 \\
\hline $\mathbf{I V}$ & $24 \dashv 36$ & 141 & 132 & 147 & 123 & 160 & 562 \\
\hline $\mathbf{V}$ & $36+48$ & 94 & 120 & 87 & 87 & 82 & 376 \\
\hline VI & $48 \dashv 60$ & 64 & 51 & 83 & 69 & 54 & 257 \\
\hline VII & $>60$ & 84 & 65 & 81 & 85 & 106 & 337 \\
\hline \multicolumn{2}{|r|}{ Total } & 820 & 751 & 835 & 871 & 823 & 3.280 \\
\hline
\end{tabular}


号

恶 
3.2.7 Avaliação da influência do regime de criação dos plantéis de Caprinos de

14 Cabris do Estado de São Paulo sobre a freqüência da ocorrência da Artrite-encefalite dos Caprinos.

Para a avaliação da influência do regime de criação - intensivo e semi-extensivo, sobre a ocorrência da Artrite-encefalite dos Caprinos a população de animais definidas nos Quadros 4 a 30 foi redistribuída como apresentou-se na Tabela 9. Nesta redistribuição, 9 plantéis eram submetidos à regime intensivo de criação e 5 criados no sistema semi-extensivo. $\mathrm{Na}$ avaliação dos caprinos do primeiro grupo plantéis em regime intensivo de criação, o número médio de caprinos avaliados foi de 576, dos quais colheram-se 2.303 amostras de soro sangüíneo (respectivamente: $521 ; 594 ; 620$ e 568 amostras no $1^{\circ}, 2^{\circ}, 3^{\circ}$ e $4^{\circ}$ momento da colheita) no período de 2 anos de duração da pesquisa - 2000/2001. Para a avaliação dos animais dos 5 plantéis criados em regime semi-extensivo, utilizou-se, em média, 244 caprinos, dos quais foram colhidas 977 amostras $\left(230,241,251\right.$ e 255 , respectivamente, na $1^{\mathrm{a}}, 2^{\mathrm{a}}$, $3^{\mathrm{a}}$ e $4^{\mathrm{a}}$ colheitas).

Tabela 9 - Distribuição dos caprinos dos 14 Cabris avaliados no Estado de São Paulo, estratificados segundo o sistema de criação (intensivo/semiextensivo), destacando-se os números de plantéis, média de animais e de amostras de soro sangüíneo colhidos. São Paulo, 2002.

\begin{tabular}{|c|c|c|c|c|c|c|c|}
\hline \multirow{2}{*}{$\begin{array}{l}\text { Sistema de } \\
\text { criação }\end{array}$} & \multirow{2}{*}{$\begin{array}{l}\text { Número de } \\
\text { plantéis }\end{array}$} & \multirow{2}{*}{$\begin{array}{l}\text { Número médio } \\
\text { de animais }\end{array}$} & \multicolumn{5}{|c|}{ Número de amostras nas colheitas } \\
\hline & & & $1^{2}$ & $2^{2}$. & $3^{a}$. & $4^{\mathrm{a}}$ & Total \\
\hline Intensivo & 9 & 576 & 521 & 594 & 620 & 568 & 2.303 \\
\hline Semi-extensivo & 5 & 244 & 230 & 241 & 251 & 255 & 977 \\
\hline Total & 14 & 820 & 751 & 835 & 871 & 823 & 3.280 \\
\hline
\end{tabular}




\subsection{Formação dos Grupos Experimentais para caracterização clínica da Artrite- encefalite dos Caprinos no Estado de São Paulo.}

Para serem conseguidos alguns dos objetivos do delineamento experimentaldesta tese, relacionado à sintomatologia dos casos clínicos observados na população àdisposição e definida anteriormente, os animais dos 14 Cabris foram redistribuídos eagrupados segundo o parâmetro a ser avaliado. Esses grupos serão definidos e detalhados a seguir.

\subsubsection{Avaliação entre infecção pelo vírus da Artrite-encefalite dos Caprinos e a ocorrência de sintomas de artrite. Forma clínica articularda doença.}

O estudo da relação do "status" de infecção ou de não infecção pelo vírus daArtriteencefalite dos Caprinos e a ocorrência de sintomas de artrite baseou-se naavaliação clínica e das condições imunológicas de 1.325 caprinos. O exame clínico dos animais antecedia a colheita de amostras de sangue, paraobtenção de soro sangüíneo, dando-se destaque à inspeção do caprino (atitudes emdecúbito ou em estação, locomoção) e observação de alterações constitucionais - aumento de volume das articulações, particularmente das articulações do carpo (radiocarpiana, intercarpiana e carpometacarpiana) e das estruturas pericarpianas. Quando houvesse aumento da articulação, fazia-se a palpação da região, pesquisandoa consistência, sensibilidade e movimentação regional; excepcionalmente houve necessidade da punção desses aumentos de volume, quando flutuantes. 
Para definição do diagnóstico nosológico de artrite, utilizou-se o Índice Clínico Articular (MONICAT, 1987, modificado por PERRIN et al, 1988), obedecendo ao clássico conceito de interpretação dos resultados desse exame clínico:quando a diferença entre os perímetros da articulação e da diáfise proximal do ossometacarpiana fosse igual ou menor do que 5,5 cm, considerava-se o resultado negativo; se essa diferença variasse entre 6,0 e 5,5 cm, o resultado era consideradosuspeito e o exame seria repetido na próxima colheita de amostras; quando a diferença fosse igual ou maior do que 7,0 cm, o resultado era considerado positivo,confirmando-se o diagnóstico nosológico de artrite da articulação do carpo - uni oubilateral. Na avaliação da relação entre as manifestações clínicas e o "status" do caprino infectado pelo vírus da Artrite-encefalite dos Caprinos, somente foramconsiderados os animais com Índico Clínico Articular - ICA positivo.

\subsubsection{Avaliação da relação entre infecção pelo vírus da Artrite-encefalitedos Caprinos e a ocorrência do endurecimento da glândula mamária. Forma clínica mamária da doença.}

A verificação da condição de cabras adultas infectadas ou não infectadas pelovírus da Artrite-encefalite dos Caprinos, em relação à ocorrência de manifestaçõesclínicas que caracterizam o endurecimento da glândula mamária, baseou-se no exameclínico e imunológico de 499 animais. O exame clínico das cabras era realizado antes da colheita das amostras desangue, para obtenção de soro sangüíneo destinadas às provas imunológicas. $\mathrm{O}$ exame da glândula mamária consistia na inspeção da 
glândula, avaliação das características macroscópicas do leite e a palpação direta do parênquima glandular.Por ser característico e sintoma essencial da mamite endurada da forma clínica mamária da Artrite-encefalite dos Caprinos, o endurecimento do tecido intersticial doparênquima mamário, conseqüente ao fibrosamento, na presente avaliação clínica, deu-se exclusivo destaque aos resultados da palpação direta da mama. As evidenciasda ocorrência do endurecimento glandular foram determinadas pela sensação de consistência dura, localizada ou generalizada do parênquima da mama. O fibrosamento do tecido mamário se constatava pela palpação de nódulos de consistência dura ou de endurecimento generalizado da mama.

\subsection{Formação de Grupos Experimentais para avaliar algumas possíveis vias de infecção do vírus da Artrite-encefalite dos Caprinos.}

Para que fossem alcançados alguns dos objetivos propostos no delineamentoexperimental desta pesquisa e elucidar vários aspectos relacionados à transmissibilidade do vírus da Artrite-encefalite dos Caprinos foram formados algunsgrupos experimentais e, para tanto, utilizaram-se cabras mantidas no Centro de Pesquisa e Diagnóstico de Enfermidades dos Ruminantes - CPDER, do Departamento de Clínica Médica da Faculdade de Medicina Veterinária e Zootecniada Universidade de São Paulo, e dos cabritos nascidos neste Centro de Pesquisa. Osgrupos experimentais formados foram detalhados a seguir. 


\subsubsection{Avaliação da transmissibilidade da infecção pelo vírus da Artrite-encefalitedos Caprinos segundo o aleitamento dos caprinos.}

Para avaliar a transmissibilidade do vírus da Artrite-encefalite dos Caprinospelo aleitamento foram utilizados 51 caprinos nascidos no Centro de Pesquisa e Diagnóstico de Enfermidades dos Ruminantes, descendentes de cabras mantidas noreferido Centro. Com esses cabritos foram formados três grupos experimentais, a seguir detalhados. GRUPO A - Deste grupo experimental, formado por 14 cabritos, que nasceram no Centro de Pesquisa e Diagnóstico de Enfermidades dos Ruminantes,foram colhidas amostras de soro sangüíneo logo ao nascer, depois que estes animaismamaram colostro com 12 e 24 horas de vida e com 7, 15, 30, 60, 90, 120, 150 e 180dias de idade. Do total de animais, nove eram filhos de mães soronegativas ao vírusda $\mathrm{AEC}$ e no aleitamento receberam $200 \mathrm{ml}$ de colostro proveniente de cabras soropositivas, sendo mantidos com as mães naturais, em baias individuais, até os 3 meses de idade, quando foram desmamados. Os outro cinco cabritos eram filhos demães infectadas pelo vírus da Artrite-encefalite dos Caprinos e tomaram $200 \mathrm{ml}$ decolostro ordenhado da própria mãe, oferecido em mamadeira. Imediatamente após onascimento estes cabritos foram separados das mães, colocados em baias individuaise passaram a receber aleitamento artificial com leite em pó, até o desmame. Logo nosprimeiros dias de vida, aos cabritos era oferecido ração, feno e sal mineral ad libitum.Os cabritos deste grupo experimental foram devidamente identificados pela colocação de coleiras com medalhas plásticas. A cama de maravalha 
das baias era trocada em dias alternados. Os cabritos eram, freqüentemente, submetidos a examescoproparasitológicos e, vermifugados a cada 2 meses, mas não receberam nenhumavacina. Objetivou-se, neste delineamento proposto, avaliar a possibilidade de infectar-se o cabrito pelo colostro de animais sororeagentes positivos, bem como detectar atransmissão passiva de anticorpos antivírus da Artrite-encefalite dos Caprinos e determinar o período de tempo necessário para que houvesse o consumo e degradação desses anticorpos.

GRUPO B - No grupo B encontravam-se 21 cabritos, que nasceram no Centro de Pesquisa e Diagnóstico de Enfermidades dos Ruminantes, todos filhos decabras infectadas pelo vírus da Artriteencefalite dos Caprinos. Destes animais foramcolhidas amostras de soro sangüíneo após o nascimento e depois que eles ingeriramo colostro, às 12 e 24 horas de vida e, a seguir, com 7, 15, 30, 60, 90, 120, 150 e 180dias de idade. Imediatamente após o nascimento, era colhida a primeira amostra desoro sangüíneo. Em seguida, os cabritos recebiam, em mamadeira, pelo menos 200ml de colostro proveniente das próprias mães infectadas pelo vírus da Artrite-encefalite dos Caprinos, sendo mantidos em baias individuais, em companhia dasgenitoras em regime de aleitamento natural, até o desmame, aos 3 meses de idade. Osistema de identificação dos cabritos foi o mesmo utilizado no grupo anteriormentedefinido. Da mesma maneira houve similaridade de manejos sanitário e alimentar. O delineamento experimental proposto visou avaliar duas possibilidades: emprimeiro lugar, a possibilidade dos anticorpos anti AEC inibirem a infecção do vírus 
em estudo e, em segundo lugar, avaliar a capacidade dos vírus presentes no colostroe/ou leite de cabras infectadas pelo vírus da Artrite-encefalite dos Caprinos infectar oscabritos.

GRUPO C - No terceiro grupo, formado por 16 cabritos, foram colhidasamostras de soro sangüíneo imediatamente após seus nascimentos e depois que esses animais mamaram colostro às 12 e 24 horas de vida, em seguida, repetiam-secolheitas de amostra de soro sangüíneo aos 7, 15, 30, 60, 90, 120, 150 e 180 dias deidade. Esses cabritos eram filhos de cabras sadias e, portanto, soronegativas aos antígenos da Artrite-encefalite dos Caprinos e receberam, no mínimo, $200 \mathrm{ml}$ de colostro oriundo das próprias mães. Logo em seguida, os cabritos foram separadosdelas, sendo 10 dos cabritos mantidos em baia coletiva e os outros 6 foram colocadosem duplas em baias pequenas, e aí permaneceram até o final do experimento. Os cabritos deste grupo receberam aleitamento artificial, até 3 meses de idade, administrado em mamadeiras individuais, onde era oferecido leite natural de cabrassoropositivas que eram mantidas no CPDER - Centro de Pesquisa e Diagnóstico deEnfermidades dos Ruminantes e ordenhadas imediatamente antes de se fazer o aleitamento dos animais. No início da criação desses cabritos, eles recebiam, diariamente, um litro de leite, sendo esta quantidade aumentada gradativa e rapidamente para 2 litros e, ao final do aleitamento, 3 litros de leite. O manejo alimentar e sanitário era semelhante ao descrito para os Grupos A e B, sendo oscabritos identificados pelo uso de colar e medalha plástica com numeração. 
Pela análise dos resultados, propunha-se, neste delineamento experimental, comprovar a possibilidade da infecção de cabritos por aleitamento com leite de cabras infectadas pelo vírus da Artrite-encefalite dos Caprinos.

Os três grupos experimentais retro definidos foram resumidos e apresentados no Quadro 31.

Quadro 31 - Distribuição dos cabritos criados e mantidos no CPDER/FMVZ-USP, que constituíram 3 grupos experimentais para avaliar a transmissibilidade do vírus da Artrite-encefalite dos Caprinos, segundo o tipo de colostro e aleitamento que receberam. São Paulo, 2002.

\begin{tabular}{|c|c|c|c|c|}
\hline Grupos & $\begin{array}{c}\mathbf{N}^{0} . \text { de } \\
\text { cabritos }\end{array}$ & \begin{tabular}{|c|} 
CABRAS \\
"status" de \\
infecção AEC \\
\end{tabular} & $\begin{array}{c}\text { COLOSTRO } \\
\text { "status" relacionado } \\
\text { à infecção AEC } \\
\end{array}$ & Aleitamento \\
\hline \multirow[t]{2}{*}{$\bar{A}$} & 9 & Negativas & Cabra infectada & Leite de cabra sadia \\
\hline & 5 & Infectadas & Cabra infectada & Leite em pó \\
\hline Subtotal & 14 & -- & Cabra infectada & Leite de cabras sadias ou de vaca \\
\hline B & 21 & Infectadas & Cabra infectada & Leite de cabra infectada \\
\hline $\mathrm{C}$ & 16 & Negativas & Cabra sadia & Leite de cabra infectada \\
\hline Total & 51 & - & - & - \\
\hline
\end{tabular}

Colheita das amostras - dos cabritos que constituíram os 3 grupos experimentais (A, B e C), foram colhidas amostras de sangue, para obtenção de soro sangüíneo, imediatamente após o nascimento e a seguir, até completarem 6 meses de idade. Assim sendo, as amostras de soro sangüíneo foram colhidas imediatamente após o nascimento, com 12 e 24 horas de vida, e com 7, 15, 30, 60, 90, 120, 150 e 180 dias de idade. Após a separação do soro, as amostras foram estocadas em 
congelador, em temperatura de $-70^{\circ} \mathrm{C}$, até o momento da realização da prova de imunodifusão em gel de ágar, para diagnóstico imuno-sorológico da Artrite-encefalitedos Caprinos. Para certificar-se que as amostras de soro sangüíneo foram colhidas imediatamente antes dos animais mamarem o colostro, 12 e 24 horas após mamaremo colostro, evidenciando a transferência passiva de imunoglobulinas, estas amostrasforam submetidas a análise bioquímica, com determinação do proteinograma, comfracionamento por eletroforese, para conhecimento dos níveis de gamaglobulina antes e após os cabritos mamarem o colostro.

\subsubsection{Avaliação da transmissibilidade da infecção pelo vírus da Artrite-encefalite dos Caprinos por via vertical - transplacentária, e no momento da parturição.}

Para avaliar a possibilidade e a intensidade da transmissão vertical da infecçãopelo vírus da Artrite-encefalite dos Caprinos em fetos e cabritos neonatos - no momento da parturição, foram utilizados 26 cabritos recém-nascidos, filhos de cabrassoro reagentes aos antígenos do mencionado vírus e que nasceram de partos eutócicos no CPDER - Centro de Pesquisa e Diagnóstico de Enfermidades dos Ruminantes do Departamento de Clínica Médica da FMVZ/USP. Amostras de sangue foram colhidas dos 26 cabritos imediatamente após onascimento e a seguir 180 dias após a ingestão de colostro de cabras positivas emsucessivas pesquisas de anticorpos antivírus da Artriteencefalite dos Caprinos. 


\subsubsection{Avaliação da transmissibilidade da infecção pelo vírus da Artrite-encefalite dos} Caprinos por inoculação de colostro, leite e sangue.

Para avaliar a transmissibilidade da infecção pelo vírus da Artrite-encefalitedos Caprinos, bem como da presença e atividade do mencionado vírus no colostro,leite e sangue circulante de animais acometidos pela Artrite-encefalite dos Caprinos,foram utilizados 15 caprinos, com idades variando entre seis e oito meses. O delineamento experimental proposto permitiu que fosse, nos casos positivos de infecção, avaliado o período de incubação, considerado o momento das inoculaçõese aquele de detecção de anticorpos antivírus da AEC, no soro sangüíneo dos cabritosinoculados, tanto por testes de imunodifusão em gel de ágar, como pela prova imunoenzimática - ELISA (EnzymeLinked-Immuno-Sorbent-Assay).

Para serem alcançados os objetivos propostos no delineamento experimental,formaramse três novos grupos experimentais, cada um constituído por cinco cabritos, que em sucessivos testes de imunodifusão em gel de ágar, não demonstraram a presença de anticorpos séricos antivírus da Artrite-encefalite dosCaprinos.

GRUPO D - O grupo D constituído por cinco cabritos, com idade variandoentre 6 e 8 meses, não possuidores de anticorpos antivírus da Artrite-encefalite dosCaprinos. Esses animais foram inoculados, por via intramuscular, com $5 \mathrm{ml}$ de leitede cabra infectada. 
GRUPO E - Este grupo também foi constituído por cinco cabritos, comidades variando entre 6 e 8 meses, em idênticas condições às definidas para os participantes do grupo anterior, sendo os animais inoculados, por via intramuscular,com $5 \mathrm{ml}$ de colostro de cabra infectada pelo vírus causador da Artrite-encefalite dosCaprinos.

GRUPO F - Os cinco cabritos com idades oscilando de 5 a 8 meses, emcondições fisiológicas idênticas às descritas para os animais dos grupos D e E, foraminoculados indiretamente, com sangue de caprinos infectados pelo vírus da Artrite-encefalite dos Caprinos. A inoculação foi realizada com o uso de tatuadores, sendoque antes da aplicação da tatuagem nos caprinos, o equipamento era contaminadocom sangue de animal infectado pelo já mencionado vírus.

Os 15 cabritos, durante a fase experimental, permaneciam em grupos de cinco, em baias coletivas, com cama de maravalha trocada periodicamente. No manejo sanitário era evitada qualquer possibilidade de transmissão iatrogênica dovírus da Artrite-encefalite dos Caprinos e os animais eram periodicamente vermifugados, de acordo com resultados coproparasitológicos. A alimentação era à base de ração concentrada comercial, feno, sal mineral e água "ad libitum”. Dessesanimais, incluídos nos três grupos experimentais, foram colhidas amostras de sangue,para obtenção de soro sangüíneo, antes das inoculações e a seguir, repetiram-se ascolheitas, com intervalos de 15 dias, até que fosse possível demonstrar de forma cabal a soroconversão, evidenciando a infecção do cabrito pelo vírus da Artrite- 
encefalite dos Caprinos. Estimou-se que seriam necessárias quatro colheitas pósinoculação.

As amostras de soro sangǘneo eram, a seguir, estocadas em congelador $-70^{\circ} \mathrm{C}$ até a realização das provas imunológicas - imunodifusão em gel de ágar e teste imunoenzimático.

A caracterização dos três grupos experimentais foi configurada no Quadro 32.

Quadro 32 - Distribuição dos cabritos inoculados com flúídos orgânicos, contendo o vírus da Artrite-encefalite dos Caprinos, segundo a via de inoculação e inóculo utilizado. São Paulo, 2002.

\begin{tabular}{|c|c|c|c|c|c|c|c|}
\hline & \multicolumn{5}{|c|}{ Número de Cabritos } \\
\hline & & & \multicolumn{5}{|c|}{ Período de colheitas em dias } \\
\hline & & & \multirow{2}{*}{$\begin{array}{c}\text { Antes da } \\
\text { inoculação }\end{array}$} & \multicolumn{4}{|c|}{ Após inoculação } \\
\hline Grupos & Via de inoculação & Inóculo & & 15 & 30 & 45 & 60 \\
\hline D & Intra muscular & Leite & 5 & 5 & 5 & 5 & 5 \\
\hline $\mathrm{E}$ & Intra muscular & Colostro & 5 & 5 & 5 & 5 & 5 \\
\hline $\bar{F}$ & Tatuagem & Sangue & 5 & 5 & 5 & 5 & 5 \\
\hline & & Total & 15 & 15 & 15 & 15 & 15 \\
\hline
\end{tabular}

\subsection{Avaliação da transferência de imunidade passiva para cabritos} neonatos, pela ingestão de colostro de cabras infectadas e não infectadas pelo vírus da Artrite-encefalite dos Caprinos.

Para estudar a transferência de imunidade passiva da cabra infectada pelo virus da Artrite-encefalite dos Caprinos foram avaliadas 108 amostras 
de soro sangüíneo de caprinos com até 180 dias de vida, crias de cabras sororeagentes positivas aos antígenos do referido vírus. Mas, também, à guisa de parâmetro de comparação, em iguais condições experimentais, avaliaram-se 147 amostras de cabritos, crias de cabras sadias e assim sendo, não reagentes aos mesmos antígenos.A quantificação das imunoglobulinas presentes no soro destes animais foi estimadapelo fracionamento eletroforético da proteína total sérica, considerando-se a fraçãogamaglobulina. As amostras de sangue foram colhidas antes das cabritos recém nascidos mamarem o colostro, 12 e 24 horas após a ingestão do colostro e, a seguir, com 7, 15,30, 60, 90, 120, 150 e 180 dias de idade. Os métodos de determinação dos teores degamaglobulina sérica, obtidas por fracionamento eletroforético e da taxa de proteínasérica total foram detalhadas no item 3.8 , relativo à determinação do proteinograma.

\subsection{Colheita do Material}

Nos momentos que antecediam a colheita das amostras de sangue dos caprinos, para obtenção do soro sangüíneo, eles eram submetidos a exame clínicogeral. Porém, quando houvesse qualquer dúvida ou necessidade de esclarecimentodas manifestações clínicas observadas, para confirmar a ocorrência de artrites, distúrbios nervosos, mamites e broncopneumonia ou mesmo a realização de diagnósticos diferenciais, o caprino era submetido a exame clínico completo, segundo as normas estabelecidas e recomendadas por ROSENBERGER (1983). 
As amostras de sangue dos caprinos para obtenção de soro foram colhidaspor punção da veia jugular externa, utilizando-se Sistema Vacutainer ${ }^{\circledR}{ }^{2}$ em tubos devidros siliconizados, sem anticoagulante, providos de tampa de borracha e com vácuopara aspirar um volume de $10 \mathrm{ml}$ (BIRGEL, 1982). Após a colheita, as amostras de sangue foram mantidas em temperatura ambiente até a coagulação e retração do coágulo, sendo transportadas para o laboratório, onde eram centrifugadas, com força real de centrifugação igual a 1000 g,durante 15 minutos, para a ocorrência de uma adequada sinerese do coágulo, comliberação do soro. A seguir, o soro sangüíneo era separado por aspiração e transferidopara frasco plástico estéril, sendo, então, mantido estocado em congelador em temperatura de $-70^{\circ} \mathrm{C}$, até o momento da realização das provas.

\subsection{Análise sorológica das amostras colhidas dos caprinos dos vários grupos experimentais.}

\subsubsection{Prova de imunodifusão em gel de ágar}

A pesquisa de anticorpos séricos antivírus da Artrite-encefalite dos Caprinos,foi realizada empregando-se a prova de Imunodifusão em Gel de Ágar (IDGA), segundo a técnica preconizada por CUTLIP et al. (1977), utilizando os antígenos glicoprotéico (gp135) e protéico (p28)

\footnotetext{
${ }^{2}$ Vacutainer®: Tubos de vidro transparente, especiais para colheita de sangue com aspiração pelo vácuo, esterilizados, sem anticoagulante, com tampa de borracha, sendo utilizadas agulhas descartáveis $(25 \mathrm{mmX} 0,8 \mathrm{~mm})$.
} 
xtraídosrespectivamente do envelope e dacápside do vírus da Artrite-encefalite dos Caprinos ${ }^{3}$.

O gel para realização da prova de IDGA foi preparado, segundo orientação dofabricante, do conjunto de reativos recomendados para detecção de anticorpos antivírus da Artriteencefalite dos Caprinos. Inicialmente, preparava-se uma soluçãotampão com 9 gramas de ácido bórico e 2 gramas de hidróxido de sódio em 950 mlde água destilada, sendo ajustado o pH para 8,6, com ácido clorídrico $(6,7 \mathrm{~N})$, ecompletado o volume para um litro. A esta solução, adicionava-se 7 gramas de ágarNOBLE® por litro, aquecido em banho-maria, até completar-se a dissolução do ágar.O gel obtido era distribuído em volumes de $18 \mathrm{ml}$ em frascos de vidro estéreis, para aseguir serem mantidos sob refrigeração até a posterior utilização. No momento douso, o conteúdo de cada um desses frascos era previamente aquecido, até a liquefação do ágar, fazendo-se sua distribuição em placa de Petri plástica, com $90 \mathrm{~mm}$ de diâmetro. Após o resfriamento do gel, para atingir a consistência firme adequada, ele era perfurado com molde metálico, em formato de roseta, contendo 6poços externos e um central, todos com diâmetro de $4 \mathrm{~mm}$ e eqüidistantes da perfuração central $(4 \mathrm{~mm})$ conforme esquema apresentado na Figura 1.

${ }^{3}$ Caprine Arthritis-Encephalitis Antibody Test Kit, Veterinary Diagnostic Technology, Inc., Wheat Ridge, Colorado, EUA. 


\section{(I)}

(6)

(7)

(5)

\section{(3)}

(4)

$7=$ antígeno $\quad 1,3,5=$ soro controle positivo $2,4,6=$ soro a ser examinado

Figura 1 - Representação esquemática da distribuição dos soros e antígenos na realização da prova de imunodifusão em gel de ágar, para detecção de anticorpos antivírus da Artrite-encefalite dos Caprinos em amostras de soro sangüíneo .

No momento da realização da prova de imunodifusão foram distribuídos em orificios alternados, volume de $40 \mu$ l do soro a ser examinado (formando um triângulo equilátero invertido - $\nabla$ ), nos demais orificios adicionavase $40 \mu \mathrm{l}$ de soro controle positivo (formando um triângulo eqüilátero $-\triangle$ ) e no orificio central adicionava-se $40 \mu \mathrm{l}$ do antígeno específico da Artrite-encefalite dos Caprinos. Após a confecção, as placas eram mantidas em câmara úmida, em temperatura ambiente $\left(25^{\circ} \mathrm{C}\right)$, sendo a primeira leitura realizada após 48 horas de incubação, e a segunda após 72 horas. Em local escuro, com o auxílio da incidência de uma fonte de luminosa (lanterna), aplicada na parte debaixo da placa de Petri, a roseta era cuidadosamente examinada para observação das reações. Como reagente positivo, foi considerado o soro que determinou nítida formação de linha de precipitação, de coloração esbranquiçada, correspondente a zona de formação do complexo antígeno-anticorpo, similares às formadas entre o soro controle e o antígeno. A reação foi considerada negativa quando as linhas dos soros de referência (controle positivo) se estendiam até o poço do soro a ser testado, sem se fechar, não 
havendo nenhuma evidência de linha de precipitação próxima do soro testado. A Figura 2 ilustra as reações positiva e negativa, como considerada nesta pesquisa.

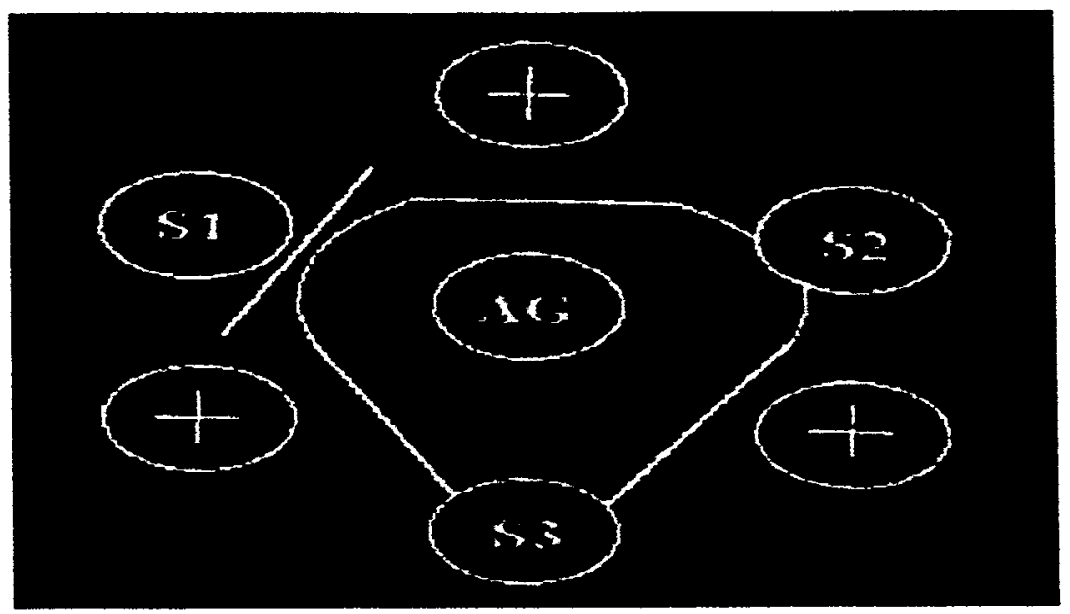

Figura 2 - Disposição do antígeno $(\mathrm{Ag})$, soro controle positivo $(+)$ e soros a serem examinados: S1 (positivo), S2 (positivo) e S3 (negativo) na prova de imunodifusão em gel de ágar, para detecção de anticorpos antivírus da Artrite-encefalite dos Caprinos em amostras de soro sangüíneo.

\subsubsection{Teste Imunoenzimático (ELISA)}

Para a detecção de anticorpos antivírus da Artrite-encefalite dos Caprinos pelo teste imunoenzimático - ELISA (Enzyme-Linked-Immuno-SorbentAssay), as amostras de soro foram submetidas à técnica usual para esses testes, como recomendaram ARCHAMBAULT et al. (1988), utilizando o Chekit CAEV/MVV 3 .

Seguindo as instruções do fabricante, as placas plásticas de 96 orificios, contendo o antígeno da Artrite-encefalite dos Caprinos, os reagentes e as amostras de soro soro sangüineo eram retirados da geladeira e deixados em

\footnotetext{
${ }^{3}$ Chekit CAEV/MMV, Bommeli AG, Berna, Suíça.
} 
temperatura ambiente. Depois que houvesse o equilíbrio das temperaturas entre os reagentes e a temperatura ambiente, colocavam-se $180 \mu$ de diluente, em cada um dos 96 orificios da placa e em seguida adicionavam-se $20 \mu \mathrm{l}$ de soros controles negativo e positivo e de soros a serem examinados; todos em duplicata, iniciando-se na coluna 1 e 2, da linha A da placa de ELISA. A diluição final das amostras de soro sangüíneo era de 1:10. Em seguida, a placa era incubada em câmara úmida, em temperatura ambiente de $25^{\circ} \mathrm{C}$, durante 90 minutos. Depois deste primeiro período de incubação as placas eram lavadas três vezes com solução de lavagem, e logo após era adicionado às amostras de soro nos orificios da placa, com o auxílio de pipeta automática multicanal, $200 \mu 1$ de conjugado IgG/anti-soro de ruminantes (1:200), sendo a seguir a placa, novamente, incubada nas mesmas condições anteriormente detalhadas, durante 90 minutos. Logo após, as placas eram lavadas três vezes, utilizando a solução de lavagem para, então, adicionar-se $200 \mu 1$ de solução cromogênica, e colocar-se $50 \mu$ de solução para deter a continuidade da reação (Stopping-solution). A leitura era realizada, 10 minutos após a colocação do último reagente mencionado, em leitor de ELISA, com filtro de comprimento de onda de $405 \mathrm{~nm}$.

A interpretação dos resultados foi realizada a partir dos valores obtidos, fazendo-se o seguinte cálculo:

\begin{tabular}{|c|c|c|}
\hline & $\begin{array}{c}\text { Média aritmética da leitura } \\
\text { da amostra examinada }\end{array}$ & $\begin{array}{c}\text { - Média aritmética da leitura } \\
\text { do soro controle negativo }\end{array}$ \\
\hline & $\begin{array}{l}\text { Média aritmética da leitura } \\
\text { do soro controle positivo }\end{array}$ & $\begin{array}{c}\text { Média aritmética da leitura } \\
\text { do soro controle negativo }\end{array}$ \\
\hline
\end{tabular}




\subsection{Determinação do proteinograma sérico}

O proteinograma do soro sangüíneo de cabritos que mamaram colostro de cabras infectadas ou não infectadas pelo vírus da Artrite-encefalite dosCaprinos, constou especificamente das determinações dos teores de proteína total eda quantificação das taxas de gamaglobulina, fração que incluiriam as imunoglobulinas responsáveis pela defesa humoral específica contra a ação de agentes infecciosos causadores de doenças.

\subsubsection{Determinação dos teores de proteína sérica total.}

A quantificação da proteína total foi realizada utilizando-se o método do Biureto, conforme a técnica descrita por GORNALL et al. (1949), modificada por STRUFALDI (1987). O método tem como princípio a reação de tripeptídeos, polipeptídeos e proteínas presentes no soro, com íons cúpricos, em meio alcalino, dando origem a um composto de coloração violeta, mensurado emanalisador bioquímico automático ${ }^{5}$, em comprimento de onda de $550 \mathrm{~nm}$.

\subsubsection{Determinação das frações protéicas séricas por eletroforese.}

O fracionamento eletroforético das proteínas séricas foi realizado deacordo com as técnicas descritas por FRIEDMAN (1961) e KREMERS et al. (1967).

${ }^{5}$ Bayer-Technicon modelo RA-100. 
Para tal procedimento, utilizou-se fitas de acetato de celulose úmidas ${ }^{6}$, previamente imersas em tampão TRIS-barbital, por 10 minutos. No momento do uso, retirava-se o excesso de tampão por secagem em papel de filtro,para a seguir identificarem-se e distenderem-se as fitas na cuba de eletroforese ${ }^{7}$. Asamostras eram aplicadas no pólo negativo da fita e, então, submetidas a uma correnteelétrica com diferença de potencial de $220 \mathrm{~V}$ por um período de 25 minutos. Apóseste período, as fitas eram removidas da cuba e coradas pelo corante Ponceau-S, por15 minutos. A seguir, fazia-se a lavagem das fitas com água, posteriormente as mergulhando em solução de ácido acético a 5\%, sendo o procedimento repetido atécompleta retirada do excesso de corante e limpeza das áreas não coradas. As fases dedesidratação e diafanização das fitas da eletroforese eram realizadas, respectivamente,por imersão em metanol p.a. durante três minutos e diafanizadas em solução composta por $84 \mathrm{ml}$ de metanol p.a. e $16 \mathrm{ml}$ de ácido acético glacial. Completado oprocessamento da eletroforese, as fitas eram estiradas em uma placa de vidro e levadas para a estufa em temperatura de $80^{\circ} \mathrm{C}$, por oito minutos, para perfeita transparentização, de modo a permitir a perfeita leitura das frações protéicas, efetuadaem densidômetro ${ }^{8}$. 


\subsubsection{Determinação da atividade sérica da enzima gamaglutamiltransferase $-\gamma$ GT.}

A atividade sérica da enzima gamaglutamiltransferase $(\gamma \mathrm{GT})$ foi determinada pelo método cinético colorimétrico, recomendado pela International Federation of Clinical Chemestry (IFCC), baseado na ação catalítica da $\gamma$ GT sobre aL-gama-glutamil-transferase-3-carboxi-4 nitranilida e glicilglicina, dando origem a L-gama-glutamilglicina e 5 amino-2-nitrobenzoato, usando-se kit comercial $^{9}$, segundotécnica modificada de SZASZ et al. (1969), em analisador bioquímico automático ${ }^{10}$,no comprimento de onda de $405 \mathrm{~nm}$.

\subsection{Análise estatística dos resultados.}

As verificações da influência dos fatores etários, raciais, sexuais e tipode criação, sobre os resultados obtidos na determinação de anticorpos séricos antivírus da Artrite-encefalite dos Caprinos em animais criados no Estado de SãoPaulo foram realizadas pelo Teste de Duas Proporções, com aproximação pela distribuição normal de probabilidade, utilizando nível de significância de 5\%, conforme recomenda BERQUÓ et al. (1981).

Para calcular os valores da média aritmética, do desvio padrão e da amplitude de variação dos resultados obtidos para os constituintes bioquímicos estudados (proteína total, gamaglobulina e gamaglutamiltransferase), no soro 
sangüíneo de caprinos jovens, bem como para realizar os testes estatísticos, comparando os resultados obtidos nos grupos experimentais (grupo de cabritos criasde cabras soronegativas e os crias de cabras soropositivas ao vírus da Artrite-encefalite dos Caprinos), foi utilizado o software SAS - Statistical Analysis Systemv. 8.1 (SAS - Institute, 2000). 


\section{RESULTADOS}

O presente estudo clínico-epidemiológico da Artrite-encefalite dos Caprinos desenvolvido em 14 propriedades criadoras de caprinos pertencentes a associados da Associação Paulista de Criadores de Caprinos (CAPRIPAULO) localizavam-se em 13 municípios do Estado de São Paulo. Nesses plantéis de gado caprino foram colhidas, em quatro momentos, intervalados por períodos de seis meses, 3.280 amostras de sangue, para obtenção de soro sangüíneo. Estas amostras foram examinadas para detectar a presença de anticorpos antivírus da Artrite-encefalite dos Caprinos e, para tal fim utilizou-se a prova da imunodifusão em gel de ágar. Também foram utilizadas amostras colhidas de 51 cabritos, nascidos e criados no Centro de Pesquisa e Diagnóstico de Enfermidades de Ruminantes (CPDER) pertencente ao Departamento de Clínica Médica da Faculdade de Medicina Veterinária e Zootecnia da Universidade de São Paulo.

Os resultados obtidos nos vários grupos experimentais propostos no delineamento desta tese foram distribuídos em 26 tabelas e 17 figuras, apresentadas a seguir. Inicialmente foram destacados os resultados referentes à ocorrência da Artrite- encefalite dos Caprinos nos fatos dos cabris selecionados, e os dados dos animais agrupados, segundo os vários parâmetros experimentais (faixa etária, sexo, raça e manejo dos animais, bem como ocorrência das formas clínicas articular e mamária da enfermidade). A seguir, foram apresentados e demonstrados os resultados obtidos nos grupos experimentais formados por cabritos e que pelo delineamento proposto avaliavam a possível transmissão do vírus da Artrite-encefalite dos Caprinos para os animais recém-nascidos, pelo colostro ou leite de cabras naturalmente infectadas. 


\subsection{Avaliação dos resultados da prova de imunodifusão em gel de agar para detecção de anticorpos antivírus da Artrite-encefalite dos Caprinos no plantel dos cabris.}

$\mathrm{Na}$ tabela 10 foram apresentados os resultados da prova de imunodifusão em gel de ágar para detecção de anticorpos antivírus da Artrite- encefalite dos Caprinos, realizada nas amostras de soro sangüíneo colhidas nos 14 cabris, nos definidos momentos, com intervalos de períodos de seis meses, num total de 4 colheitas. O número absoluto (número de amostras avaliadas) e o número relativo, expressando o percentual de sororeagentes em cada colheita, assim como para o número total de amostras avaliadas. Para melhor visualização destes resultados, eles foram colocados na figura 3.

Entre as 14 propriedades avaliadas, demonstrou-se que 28,6\% (4/14) dos rebanhos estavam e mantiveram-se livres da Artrite-encefalite dos Caprinos e 71,4\% (10/14), constituíram o grupo de propriedades, nas quais a infecção causada pelo mencionado vírus foi detectada, pois neles haviam caprinos sororeagentes ao antígeno da AEC. Ressalte-se que um Cabril, inicialmente, com prevalência de 20,0\% (4/20) de caprinos infectados pelo vírus da Artrite-encefalite dos Caprinos, após aplicação das medidas de profilaxia recomendadas (descarte dos caprinos sororeagentes positivos), o fato de caprinos permaneceu livre da infecção em três colheitas sucessivas, intervaladas por período de seis meses. 


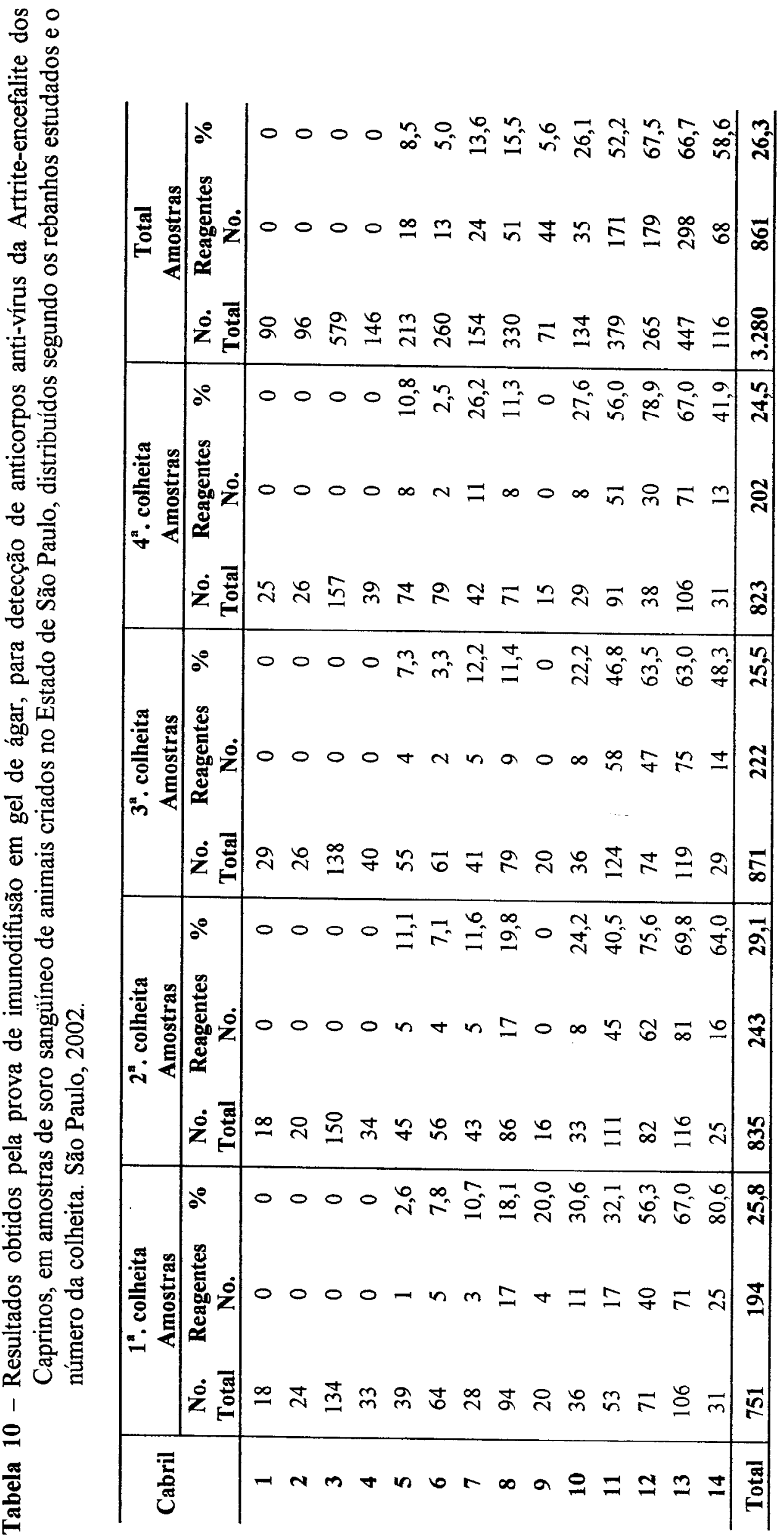




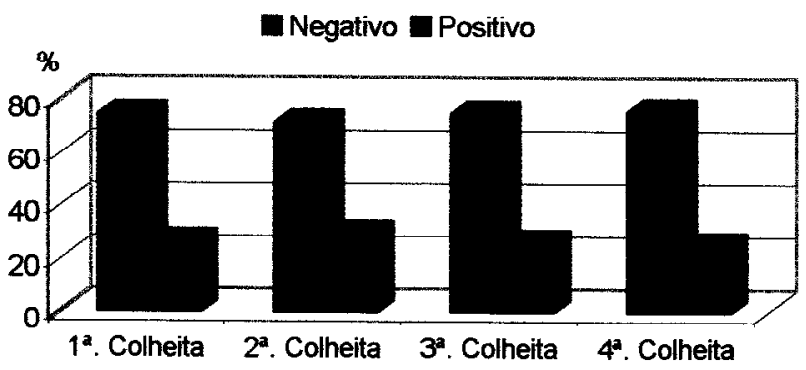

Figura 3 - Distribuição percentual da freqüência da ocorrência de Artrite-encefalite dos Caprinos, nos quatro momentos avaliados. São Paulo, 2002.

Tabela 11 - Análise estatística das freqüências de anticorpos antivírus da Artriteencefalite dos Caprinos em animais criados no Estado de São Paulo, distribuídos segundo a colheita realizada. São Paulo, 2002.

\begin{tabular}{|c|c|c|c|}
\hline Contraste & $\begin{array}{c}\text { Freqüência (\%) de amostras } \\
\text { sororeagentes } \\
\end{array}$ & Valor de $\mathbf{Z}$ & $\begin{array}{c}\text { Significância } \\
\text { estatística }\end{array}$ \\
\hline $1^{\mathrm{a}}$. colheita $X 2^{\mathrm{a}}$. colheita & $25,8 \times 29,1$ & 1,469 & NS \\
\hline $1^{\mathrm{a}}$. colheita $\times 3^{\mathrm{a}}$. colheita & $25,8 \times 25,5$ & 0,138 & NS \\
\hline $1^{\mathrm{a}}$. colheita $X 4^{\mathrm{a}}$. colheita & $25,8 \times 24,5$ & 0,594 & NS \\
\hline $2^{\mathrm{a}}$. colheita $X 3^{\mathrm{a}}$. colheita & $29,1 \times 25,5$ & 1,669 & NS \\
\hline $2^{\mathrm{a}}$. colheita $\times 4^{\mathrm{a}}$. colheita & $29,1 \times 24,5$ & 2,114 & $\mathbf{S}$ \\
\hline $3^{\mathrm{a}}$. colheita $X 4^{\mathrm{a}}$. colheita & $25,5 \times 24,5$ & 0,475 & NS \\
\hline
\end{tabular}

Teste de Duas Proporções: Valor de $Z$ crítico $=1,96$.

$\mathrm{S}=$ significante; $\mathrm{NS}=$ não significante

A análise estatística dos dados contidos na tabela 10 , mediante o

Teste de Duas Proporções demonstrou resultados estatisticamente significantes, conforme pôde ser observado na tabela 11 , que mostra que o percentual de reagentes da segunda colheita foi maior do que o obtido na quarta colheita.

Nas variações do número absoluto e relativo de caprinos com anticorpos antivírus da Artrite-encefalite dos Caprinos observou-se que: a prevalência da infecção nos 14 plantéis estudados no período de dois anos - 20002001 foi igual a 26,3\% (861/3280); apesar das oscilações da freqüência da ocorrência nos quatro momentos das colheitas serem de pequena magnitude 25,8\% (194/751), $29,1 \%(243 / 835), 25,5 \%(222 / 871)$ e $24,5 \%(202 / 823)$, respectivamente na $1^{\mathrm{a}}, 2^{\mathrm{a}}$,, $3^{\mathrm{a}}$. e $4^{\mathrm{a}}$. colheitas, em quatro plantéis houve gradativa diminuição da freqüência da 
ocorrência da infecção - cabris 6, 8, 9 e 14, em um deles a infecção foi erradicada (cabril 9), em três houve estabilização dos resultados - plantéis 10,12 e 13 e, em outros três verificou-se incremento dos valores estudados - fatos de caprinos de números 5, 7 e 11. Ressalte-se que quatro criatórios, mantiveram seus rebanhos livres da infecção pelo vírus da Artrite-encefalite dos Caprinos - cabris 1, 2, 3 e 4 .

4.2 Análise dos resultados da prova de imunodifusão em gel de ágar para a Artrite-encefalite dos Caprinos, obtidos para avaliar a incidência da infecção em plantéis de caprinos criados no Estado de São Paulo.

Os resultados obtidos nos soros sanguíneos dos caprinos avaliados nesse item do delineamento experimental, considerando a incidência da infecção no plantel, isto é, a determinação do aparecimento de novos casos de Artrite-encefalite dos Caprinos nas propriedades pesquisadas, foram transcritos na Tabela 12 .

Tabela 12 - Número e percentual de casos novos de Artrite-encefalite dos Caprinos, em animais criados no Estado de São Paulo. São Paulo, 2002.

\begin{tabular}{|c|c|c|c|c|c|c|c|c|}
\hline \multirow{3}{*}{ Cabril } & \multirow{2}{*}{\multicolumn{2}{|c|}{$\begin{array}{c}\text { Prevalência } \\
1^{\mathrm{a}} \text {. colheita }\end{array}$}} & \multicolumn{6}{|c|}{ Incidência } \\
\hline & & & \multicolumn{2}{|c|}{$2^{n}$. colheita } & \multicolumn{2}{|c|}{$3^{2}$. colheita } & \multicolumn{2}{|c|}{$4^{\mathrm{a}}$. coiheita } \\
\hline & Reagentes & $\%$ & Reagentes & $\%$ & Reagentes & $\%$ & Reagentes & $\%$ \\
\hline 1 & $0 / 18$ & 0 & $0 / 18$ & 0 & $0 / 29$ & 0 & $0 / 25$ & 0 \\
\hline 2 & $0 / 24$ & 0 & $0 / 20$ & 0 & $0 / 26$ & 0 & $0 / 26$ & 0 \\
\hline 3 & $0 / 134$ & 0 & $0 / 150$ & 0 & $0 / 138$ & 0 & $0 / 157$ & 0 \\
\hline 4 & $0 / 33$ & 0 & $0 / 34$ & 0 & $0 / 40$ & 0 & $0 / 39$ & 0 \\
\hline 5 & $1 / 39$ & 2,6 & $4 / 45$ & 8,9 & $0 / 51$ & 0 & $4 / 68$ & 5,9 \\
\hline 6 & $5 / 64$ & 7,8 & $3 / 55$ & 5,5 & $2 / 61$ & 3,3 & $0 / 77$ & 0 \\
\hline 7 & $3 / 28$ & 10,7 & $4 / 41$ & 9,8 & $1 / 37$ & 2,7 & $5 / 37$ & 13,5 \\
\hline 8 & $17 / 94$ & 18,1 & $1 / 86$ & 1,2 & $6 / 79$ & 7,6 & $6 / 71$ & 8,5 \\
\hline 9 & $4 / 20$ & 20,0 & $0 / 16$ & 0 & $0 / 20$ & 0 & $0 / 15$ & 0 \\
\hline 10 & $11 / 36$ & 30,6 & $0 / 25$ & 0 & $1 / 29$ & 3,4 & $0 / 21$ & 0 \\
\hline 11 & $17 / 53$ & 32,1 & $38 / 87$ & 43,7 & $24 / 71$ & 33,8 & $15 / 55$ & 27,3 \\
\hline 12 & $40 / 71$ & 56,3 & $22 / 42$ & 52,4 & $2 / 29$ & 6,9 & $2 / 10$ & 20,0 \\
\hline 13 & $71 / 106$ & 67,0 & $39 / 73$ & 53,4 & $12 / 55$ & 21,8 & $10 / 45$ & 22,2 \\
\hline 14 & $25 / 31$ & 80,6 & $3 / 11$ & 27,3 & $1 / 16$ & 6,3 & $2 / 20$ & 10,0 \\
\hline Total & $194 / 751$ & 25,8 & $114 / 703$ & 16,2 & $49 / 681$ & 7,2 & $44 / 666$ & 6,6 \\
\hline
\end{tabular}


Tabela 13 - Análise estatística das taxas de incidência da Artrite-encefalite dos Caprinos em animais criados no Estado de São Paulo, distribuídos segundo a colheita realizada. São Paulo, 2002.

\begin{tabular}{cccc}
\hline $\begin{array}{c}\text { Contraste } \\
\text { das taxas de incidência }\end{array}$ & Taxa de incidência (\%) & Valor de Z & $\begin{array}{c}\text { Significância } \\
\text { estatística }\end{array}$ \\
\hline $2^{\mathbf{a}}$. colheita $\times 3^{\mathbf{a}}$. colheita & $16,2 \times 7,2$ & 5,194 & $\mathrm{~S}$ \\
$2^{\mathrm{a}}$. colheita $\mathrm{X} 4^{\mathrm{a}}$. colheita & $16,2 \times 6,6$ & 5,559 & $\mathrm{~S}$ \\
$3^{\mathrm{a}}$. colheita $\mathrm{X} 4^{\mathrm{a}}$. colheita & $7,2 \times 6,6$ & 0,434 & $\mathrm{NS}$ \\
\hline
\end{tabular}

Teste de Duas Proporções: Valor de Z crítico $=1,96$.

$\mathrm{S}=$ significante; $\mathrm{NS}=$ não significante

A análise estatística dos dados contidos na tabela 12 , mediante $\mathrm{o}$

Teste de Duas Proporções demonstrou resultados estatisticamente significantes, conforme pode ser observado na tabela 13 , que mostra que a taxa de incidência da Artrite-encefalite dos Caprinos da segunda colheita foi maior do que as obtidas na terceira e quarta colheitas.

4.3 Análise dos resultados da prova de imunodifusão em gel de ágar para deteç̧ão de anticorpos antivírus da Artrite-encefalite dos Caprinos, considerando a raça de caprinos criados no Estado de São Paulo.

Os resultados obtidos nos soros sangüíneos estudados, levando-se em consideração a raça dos caprinos, que constituíram os grupos experimentais, foram consubstanciados nas tabelas 14 e 15 e para melhor visualização dos resultados, foram delineados na figura 4. 


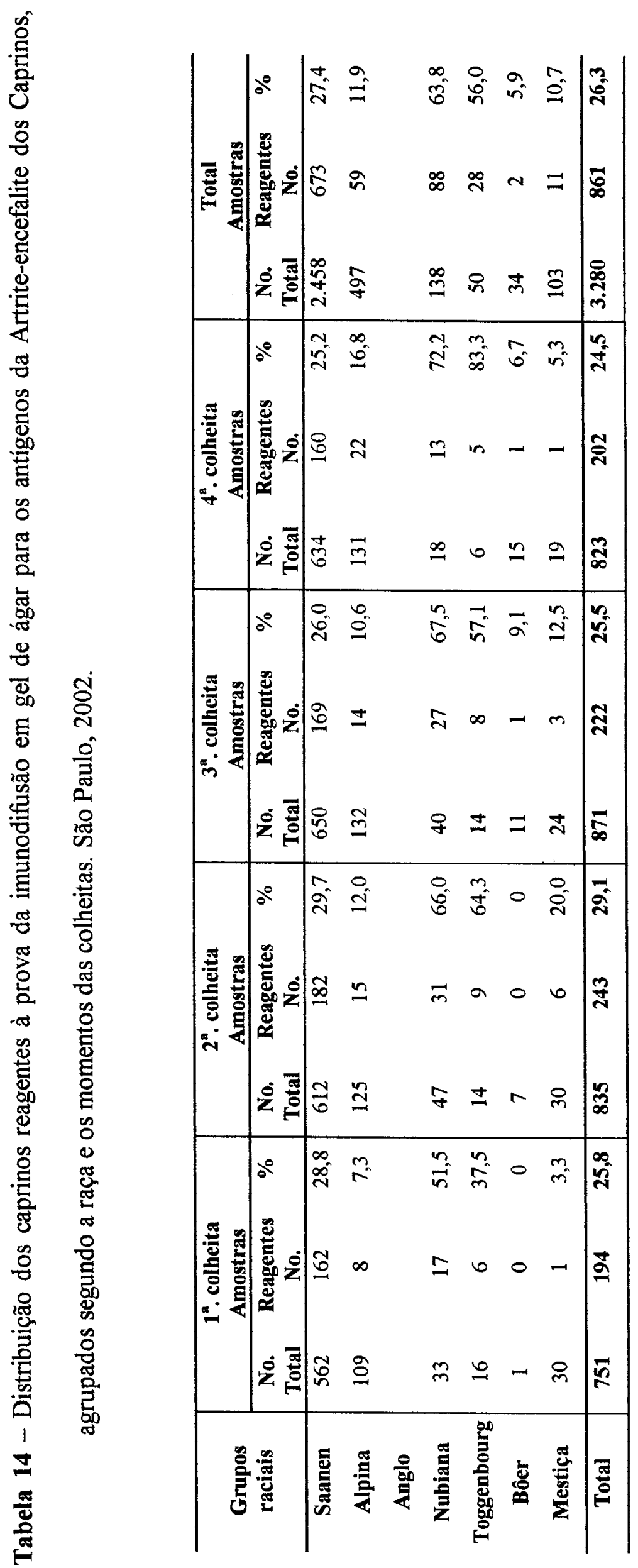


Tabela 15 - Distribuição dos caprinos reagentes e não reagentes à prova da imunodifusão em gel de ágar para os antígenos da Artrite-encefalite dos Caprinos, agrupados segundo a raça. São Paulo, 2002.

\begin{tabular}{lccccc}
\hline & \multicolumn{5}{c}{ RESULTADOS } \\
\cline { 2 - 5 } Raça & Reagentes & \% & Não Reagentes & \% & Total \\
\hline Saanen & 673 & 27,4 & 1785 & 72,6 & 2458 \\
Alpina & 59 & 11,9 & 438 & $\mathbf{8 8 , 1}$ & 497 \\
Anglo Nubiana & 88 & 63,8 & 50 & 36,2 & 138 \\
Toggenbourg & 28 & 56,0 & 22 & 44,0 & 50 \\
Bôer & 2 & 5,9 & 32 & 94,1 & 34 \\
Mestiços & 11 & 10,7 & 92 & $\mathbf{8 9 , 3}$ & 103 \\
\hline Total & $\mathbf{8 6 1}$ & $\mathbf{2 6 , 3}$ & $\mathbf{2 4 1 9}$ & $\mathbf{7 3 , 7}$ & $\mathbf{3 2 8 0}$ \\
\hline
\end{tabular}

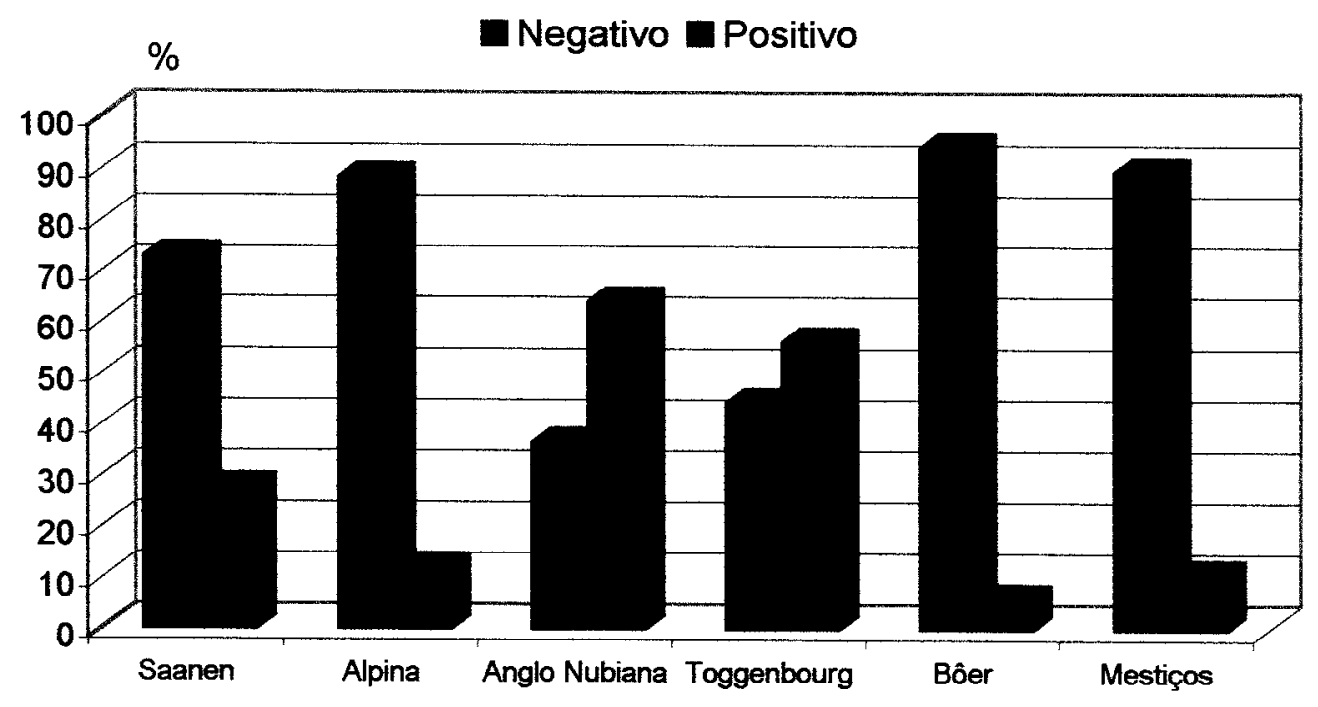

Figura 4 - Freqüência da ocorrência de anticorpos da Artrite-encefalite dos Caprinos, determinada pela prova de imunodifusão em gel de ágar, em caprinos criados no Estado de São Paulo. Distribuição segundo a raça. São Paulo, 2002. 
Tabela 16 - Análise estatística das freqüências de anticorpos antivírus da Artriteencefalite dos Caprinos em animais criados no Estado de São Paulo, distribuídos segundo a raça. São Paulo, 2002.

\begin{tabular}{lccc}
\hline Contraste entre grupos etários & $\begin{array}{c}\text { Freqüência (\%) de } \\
\text { amostras sororeagentes }\end{array}$ & Valor de Z & $\begin{array}{c}\text { Significância } \\
\text { estatística }\end{array}$ \\
\hline Saanen X Alpina & $27,4 \times 11,9$ & 7,298 & $\mathrm{~S}$ \\
Saanen X Anglo Nubiana & $27,4 \times 63,8$ & 9,139 & $\mathrm{~S}$ \\
Saanen X Toggenbourg & $27,4 \times 56,0$ & 4,460 & $\mathrm{~S}$ \\
Saanen X Bôer & $27,4 \times 5,9$ & 2,801 & $\mathrm{~S}$ \\
Saanen X Mestiços & $27,4 \times 10,7$ & 3,752 & $\mathrm{~S}$ \\
Alpina X Anglo Nubiana & $11,9 \times 63,8$ & 12,782 & $\mathrm{~S}$ \\
Alpina X Toggenbourg & $11,9 \times 56,0$ & 8,122 & $\mathrm{~S}$ \\
Alpina X Bôer & $11,9 \times 5,9$ & 1,060 & NS \\
Alpina X Mestiços & $11,9 \times 10,7$ & 0,345 & $\mathrm{NS}$ \\
Anglo Nubiana X Toggenbourg & $63,8 \times 56,0$ & 0,972 & NS \\
Anglo Nubiana X Bôer & $63,8 \times 5,9$ & 6,055 & $\mathrm{~S}$ \\
Anglo Nubiana X Mestiços & $63,8 \times 10,7$ & 8,288 & $\mathrm{~S}$ \\
Toggenbourg X Bôer & $56,0 \times 5,9$ & 4,704 & $\mathrm{~S}$ \\
Toggenbourg X Mestiços & $56,0 \times 10,7$ & 6,030 & $\mathrm{~S}$ \\
Bôer X Mestiços & $5,9 \times 10,7$ & 0,827 & NS \\
\hline Teste de Duas Proporç̃̃es: Valor de Z
\end{tabular}

Teste de Duas Proporções: Valor de $\mathrm{Z}$ crítico $=1,96$.

$\mathrm{S}=$ significante; $\mathrm{NS}=$ não significante

$\mathrm{Na}$ tabela 16, foi apresentado o resultado da análise estatística, realizada pelo Teste de Duas Proporções, avaliando-se os contrastes entre parâmetros dos diferentes agrupamentos raciais, demonstrando haver diferença significativa entre as diferenças dos resultados obtidos em caprinos pertencentes à raça Saanen e as demais raças. Fato similar foi demonstrado entre os resultados obtidos nas amostras de soro sangüíneo colhidas de caprinos da raça Alpina e os das raças Anglo Nubiana e Toggenbourg; como também, foram estatisticamente significante, as diferenças entre os resultados obtidos para a raça Anglo Nubiana e aqueles da raça Bôer e no grupo racial de caprinos mestiços, tendo ocorrido o mesmo quando se compararam as diferenças entre freqüência de caprinos da raça Toggenbourg 
reagentes aos antígenos do vírus da artrite-encefalite dos Caprinos e aqueles de animais da raça Bôer e do grupo de caprinos mestiços. Apenas as diferenças obtidas para os parâmetros comparando a freqüência da ocorrência de anticorpos antivírus AEC entre agrupamento das raças: Alpina X Bôer; Alpina X Mestiços; Anglo Nubiana X Toggenbourg e Bôer X Mestiços.

4.4 Análise dos resultados da prova de imunodifusão em gel de ágar para detecção de anticorpos antivírus da Artrite-encefalite dos Caprinos, considerando o sexo de animais criados no Estado de São Paulo.

Os resultados obtidos na presente pesquisa em amostras de soro sangüíneo colhidas de caprinos criados no Estado de São Paulo e agrupados segundo o sexo, considerando-se sempre caprinos púberes, isto é, com mais de 8 meses de idade, foram transcritos na tabela 17 , mas para melhor visualização eles foram, também, configurados na figura 5.

Tabela 17 - Distribuição dos caprinos reagentes e não reagentes à prova da imunodifusão em gel de ágar para os antígenos da Artrite-encefalite dos Caprinos, agrupados segundo o sexo. São Paulo, 2002.

\begin{tabular}{|c|c|c|c|c|c|}
\hline \multirow[t]{2}{*}{ Sexo } & \multicolumn{4}{|c|}{ RESULTADOS } & \multirow[t]{2}{*}{ Total } \\
\hline & Reagentes & $\%$ & Não Reagentes & $\%$ & \\
\hline Masculino & 94 & 32,3 & 197 & 67,7 & 291 \\
\hline Feminino & 663 & 27,9 & 1.712 & 72,1 & 2.375 \\
\hline Total & 757 & 28,4 & 1.909 & 71,6 & 2.666 \\
\hline
\end{tabular}




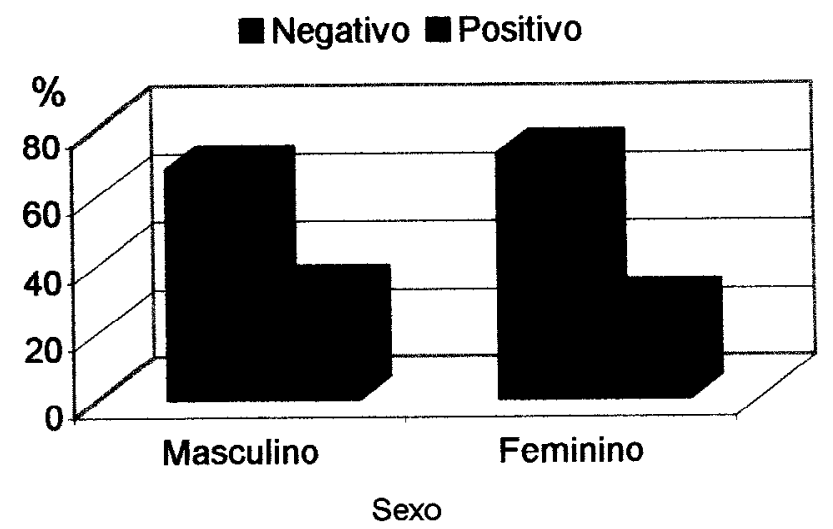

Figura 5 - Freqüência da ocorrência de anticorpos antivírus da Artrite-encefalite dos Caprinos, determinada pela prova de imunodifusão em gel de ágar, em caprinos criados no Estado de São Paulo. Distribuição segundo o sexo dos animais. São Paulo, 2002.

Tabela 18 - Análise estatística das freqüências de anticorpos antivírus da Artriteencefalite dos Caprinos determinadas em animais criados no Estado de São Paulo, distribuídos segundo o sexo. São Paulo, 2002.

\begin{tabular}{cccc}
\hline $\begin{array}{c}\text { Contraste } \\
\text { entre sexos }\end{array}$ & $\begin{array}{c}\text { Freqüência (\%) de amostras } \\
\text { sororeagentes }\end{array}$ & Valor de $\mathbf{Z}$ & $\begin{array}{c}\text { Significância } \\
\text { estatística }\end{array}$ \\
\hline Masculino X Feminino & $32,3 \times 27,9$ & 1,571 & NS \\
\hline
\end{tabular}

Teste de Duas Proporções: Valor de Z crítico $=1,96$.

NS = não significante

A análise estatística realizada, através do Teste de Duas Proporções, demonstrou não haver diferença significativa entre os resultados obtidos nas amostras colhidas de caprinos do sexo feminino e aquelas dos animais do sexo masculino, como foi demonstrado na tabela 18 . 


\subsection{Análise dos resultados da prova de imunodifusão em gel de ágar para detecção de anticorpos antivírus da Artrite-encefalite dos Caprinos, considerando a faixa etária de grupos de animais criados no Estado de São Paulo.}

Os resultados obtidos da detecção de anticorpos antivírus da Artrite- encefalite dos Caprinos em soros sangüíneos de caprinos criados no Estado de São Paulo, categorizados segundo as faixas etárias dos animais incluidos nesse experimento, foram transcritos na tabela 19. A estratificação dos caprinos segundo a faixa etária, se deu em 7 grupos etários que foram assim distribuídos: até 6 meses; 612 meses; 1224 meses; 2436 meses; 3648 meses; 4860 meses e mais do que 60 meses de idade. Os resultados gerais obtidos em cada propriedade estão demonstrados na tabela 20. Para melhor visualização desses dados, eles foram distribuídos na figura 6 . 
哭

욤

売

ซึ

\&

哭

8

莡

莺

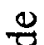

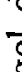

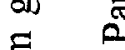

政

in

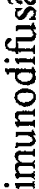

ำ

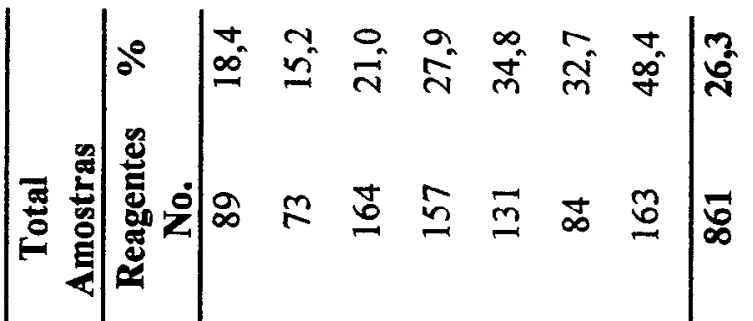

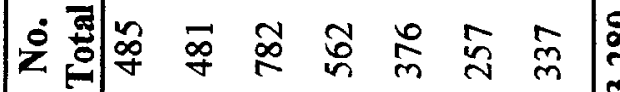

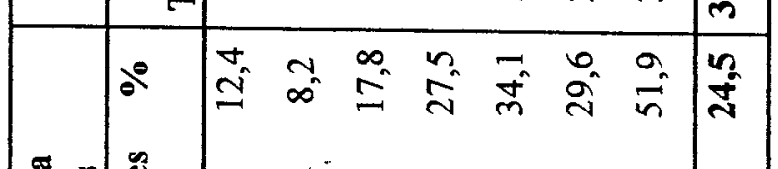

焉

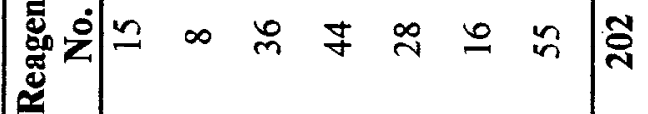
我 से

$\frac{\rho^{n}}{\tilde{z}^{n}}$

นี

莺

苛

-

농 윰

$\stackrel{8}{20}$

$\pm \quad$

$\stackrel{0}{0} 0$

营

\&

)

.

$\frac{1}{2}$

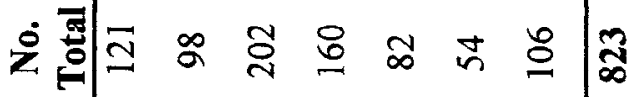

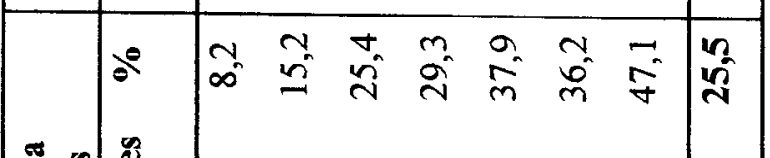

풀

焉焉 कें से

运晋壬

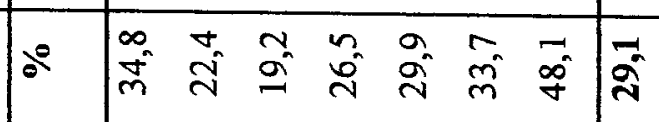

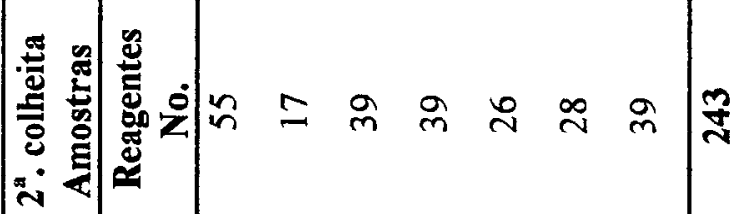

之:

茎

幽

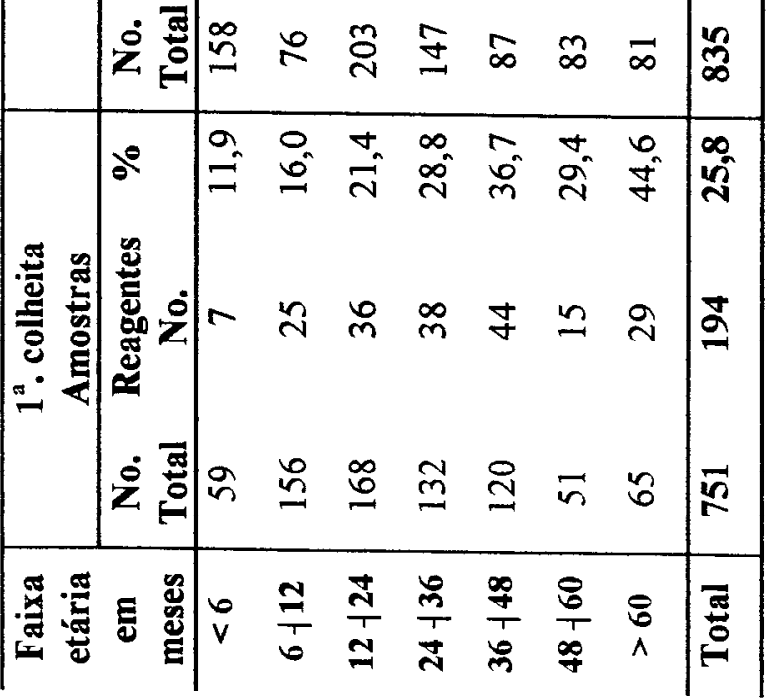


Tabela 20 - Distribuição dos caprinos reagentes à prova da imunodifusão em gel de ágar para os antígenos da Artrite-encefalite dos Caprinos, segundo a faixa etária. São Paulo, 2002.

\begin{tabular}{|c|c|c|c|c|c|}
\hline \multirow{3}{*}{$\begin{array}{c}\text { Faixa } \\
\text { etária em } \\
\text { meses }\end{array}$} & \multicolumn{4}{|c|}{ RESULTADOS } & \multirow{3}{*}{ Total } \\
\hline & \multicolumn{2}{|c|}{ Reagentes } & \multicolumn{2}{|c|}{ Não Reagentes } & \\
\hline & $\mathbf{N}^{0}$. & $\%$ & $\mathbf{N}^{0}$ & $\%$ & \\
\hline$<6$ & 89 & 18,4 & 396 & 81,6 & 485 \\
\hline $6+12$ & 73 & 15,2 & 408 & 84,8 & 481 \\
\hline $12+24$ & 164 & 21,0 & 618 & 79,0 & 782 \\
\hline $24+36$ & 157 & 27,9 & 405 & 72,1 & 562 \\
\hline $36+48$ & 131 & 34,8 & 245 & 65,2 & 376 \\
\hline $48+60$ & 84 & 32,7 & 173 & 67,3 & 257 \\
\hline$>60$ & 163 & 48,4 & 174 & 51,6 & 337 \\
\hline Total & 861 & 26,3 & 2416 & 73,7 & 3280 \\
\hline
\end{tabular}

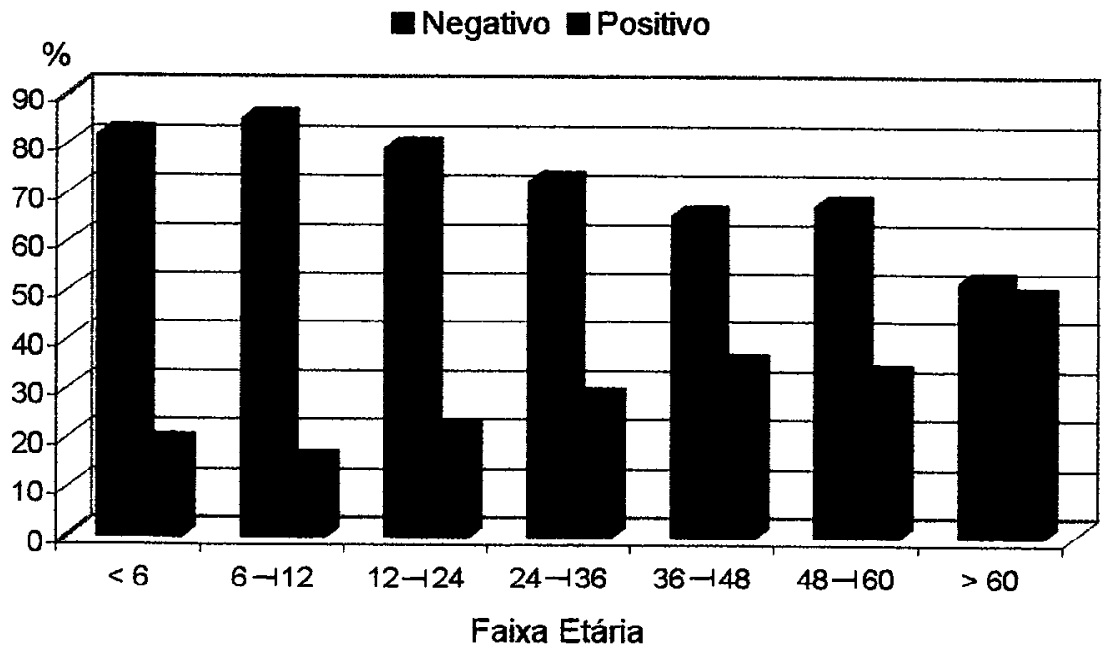

Figura 6 - Freqüência da ocorrência de anticorpos séricos antivírus da Artriteencefalite dos Caprinos, determinada pela prova de imunodifusão em gel de ágar, em caprinos criados no Estado de São Paulo. Distribuição segundo a faixa etária. São Paulo, 2002. 
Tabela 21 - Análise estatística das freqüências de anticorpos antivírus da Artriteencefalite dos Caprinos determinados em animais criados no Estado de São Paulo, distribuídos segundo a faixa etária. São Paulo, 2002.

\begin{tabular}{|c|c|c|c|}
\hline $\begin{array}{c}\text { Contraste entre } \\
\text { faixas etárias } \\
\end{array}$ & $\begin{array}{c}\text { Frequiência (\%) de amostras } \\
\text { sororeagentes }\end{array}$ & Valor de $Z$ & $\begin{array}{c}\text { Significância } \\
\text { estatística }\end{array}$ \\
\hline$<6 \times 6+12$ & $18,4 \times 15,2$ & 1,330 & NS \\
\hline$<6 \times 12 \nmid 24$ & $18,4 \times 21,0$ & 1,125 & NS \\
\hline$<6 \times 24 \nmid 36$ & $18,4 \times 27,9$ & 3,615 & $\mathrm{~S}$ \\
\hline$<6 \times 36 \uparrow 48$ & $18,4 \times 34,8$ & 5,472 & S \\
\hline$<6 \times 48+60$ & $18,4 \times 32,7$ & 4,381 & $\mathrm{~S}$ \\
\hline$<6 X>60$ & $18,4 \times 48,4$ & 9,171 & S \\
\hline $6 \dashv 12 \times 12 \nmid 24$ & $15,2 \times 21,0$ & 2,562 & S \\
\hline $6+12 \times 24+36$ & $15,2 \times 27,9$ & 4,932 & S \\
\hline $6+12 \times 36+48$ & $15,2 \times 34,8$ & 6,686 & S \\
\hline $6 \dashv 12 \times 48 \dashv 60$ & $15,2 \times 32,7$ & 5,532 & $\mathrm{~S}$ \\
\hline $6 \dashv 12 x>60$ & $15,2 \times 48,4$ & 10,313 & S \\
\hline $12 \nmid 24 \times 24 \nmid 36$ & $21,0 \times 27,9$ & 2,926 & S \\
\hline $12 \nmid 24 \times 36 \dashv 48$ & $21,0 \times 34,8$ & 5,046 & S \\
\hline $12 \dashv 24 \times 48 \dashv 60$ & $21,0 \times 32,7$ & 3,816 & $\mathrm{~S}$ \\
\hline $12 \nmid 24 x>60$ & $21,0 \times 48,4$ & 9,243 & S \\
\hline $24 \nmid 36 \times 36 \nmid 48$ & $27,9 \times 34,8$ & 2,246 & S \\
\hline $24+36 \times 48+60$ & $27,9 \times 32,7$ & 1,399 & NS \\
\hline $24+36 x>60$ & $27,9 \times 48,4$ & 6,215 & $\mathrm{~S}$ \\
\hline $36 \dashv 48 \times 48+60$ & $34,8 \times 32,7$ & 0,548 & NS \\
\hline $36+48 x>60$ & $34,8 \times 48,4$ & 3,683 & $S$ \\
\hline $48+60 x>60$ & $32,7 \times 48,4$ & 3,846 & $S$ \\
\hline
\end{tabular}

Teste de Duas Proporções: Valor de $\mathrm{Z}$ crítico $=1,96$.

$\mathrm{S}=$ significante $; \mathrm{NS}=$ não significante

A análise estatística, realizada pelo Teste de Duas Proporções, e apresentada na tabela 21, demonstrou haver diferença significativa entre os resultados obtidos em caprinos pertencentes aos diferentes grupos etários, sendo a freqüência média significativamente menor nos caprinos mais jovens, aumentando gradativa e significativamente com o evoluir da idade. 
4.6 Análise dos resultados da prova de imunodifusão em gel de ágar para a detecção de anticorpos antivírus da Artrite-encefalite dos Caprinos, considerando o sistema de criação em caprinos do Estado de São Paulo.

Os resultados obtidos em amostras de soros sangüíneos colhidas de caprinos criados em 14 plantéis de 13 municípios do Estado de São Paulo, agrupados segundo o sistema de criação a que eram submetidos, foram demonstrados nas tabelas 22 e 23 . Todavia para melhor visualização dos resultados, eles foram delineados na figura 7. 


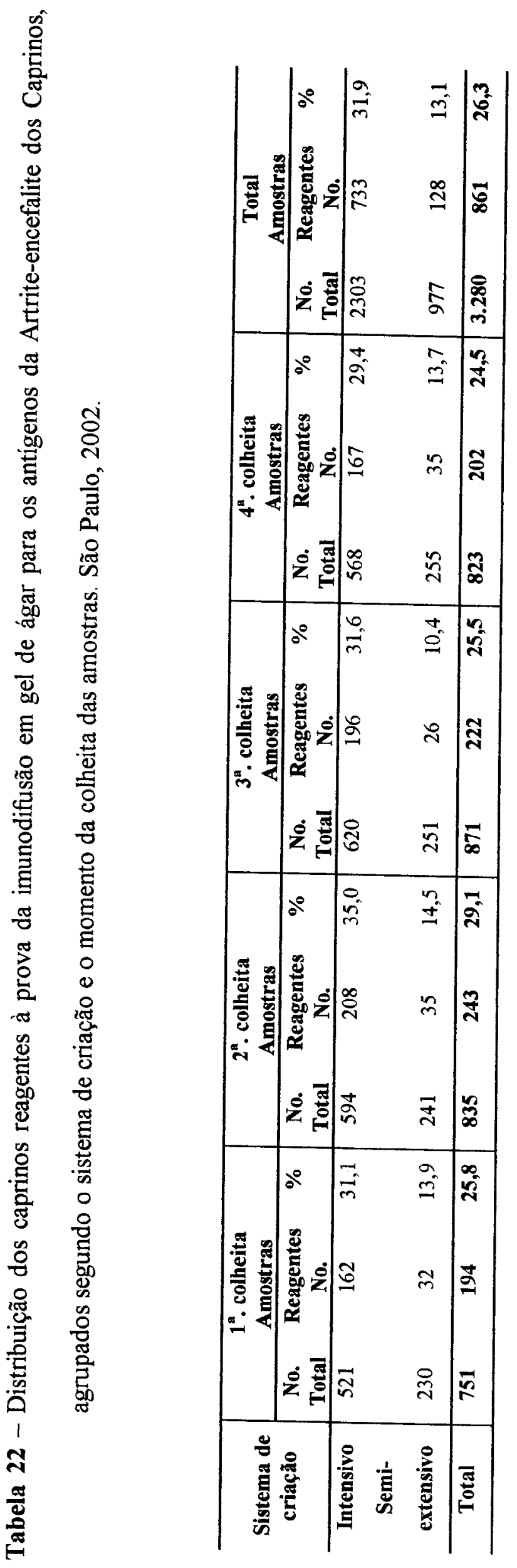


Tabela 23 - Distribuição dos caprinos reagentes e não reagentes à prova da imunodifusão em gel de ágar para os antígenos da Artrite-encefalite dos Caprinos, agrupados segundo o sistema de criação. São Paulo, 2002.

\begin{tabular}{|c|c|c|c|c|c|}
\hline \multirow{3}{*}{$\begin{array}{c}\text { Sistema de } \\
\text { Criacão }\end{array}$} & \multicolumn{4}{|c|}{ RESULTADOS } & \multirow{3}{*}{ Total } \\
\hline & \multicolumn{2}{|c|}{ Reagentes } & \multicolumn{2}{|c|}{ Não Reagentes } & \\
\hline & $\mathbf{N}^{\circ}$ & $\%$ & $\mathbf{N}^{0}$ & $\%$ & \\
\hline Intensivo & 733 & 31,8 & 1570 & 68,2 & 2303 \\
\hline Semi-extensivo & 128 & 13,1 & 849 & 86,9 & 977 \\
\hline Total & 861 & 26,3 & 2419 & 73,7 & 3280 \\
\hline
\end{tabular}

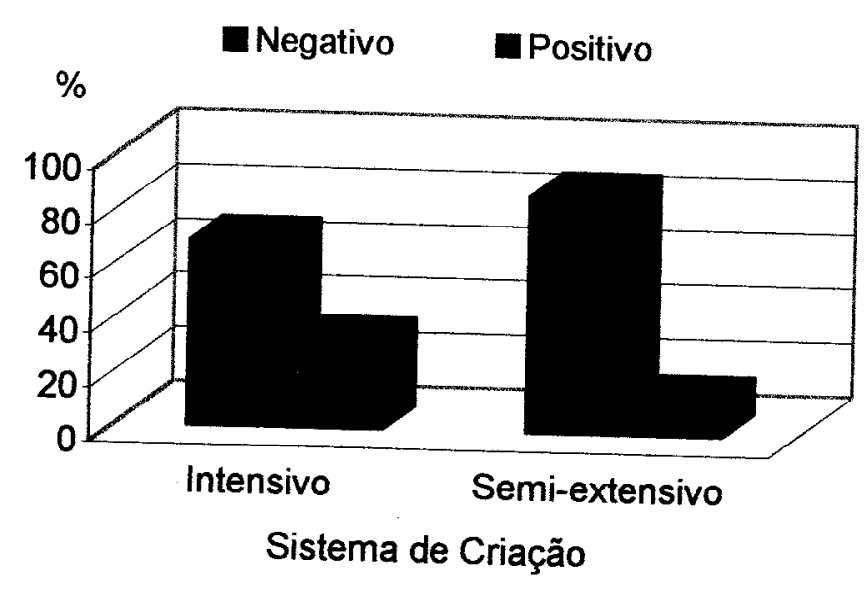

Figura 7 - Freqüência da ocorrência de anticorpos antivírus da Artrite-encefalite dos Caprinos, determinada pela prova de imunodifusão em gel de ágar, em caprinos criados no Estado de São Paulo. Distribuição segundo o sistema de criação. São Paulo, 2002.

Tabela 24 - Análise estatística das freqüências de anticorpos antivírus da Artriteencefalite dos Caprinos determinadas em animais criados no Estado de São Paulo, distribuídos segundo o sistema de criação. São Paulo, 2002.

\begin{tabular}{lccc}
\hline $\begin{array}{c}\text { Contraste } \\
\text { entre sistemas de criação }\end{array}$ & $\begin{array}{c}\text { Freqüência (\%) de } \\
\text { amostras sororeagentes }\end{array}$ & Valor de Z & $\begin{array}{c}\text { Significância } \\
\text { estatística }\end{array}$ \\
\hline Intensivo X Semi-extensivo & $31,8 \times 13,1$ & 11,134 & $\mathrm{~S}$ \\
\hline Teste de Duas Proporções: Valor de $\mathrm{Z}$ crítico $=1,96$. & & \\
$\mathrm{S}=$ significante
\end{tabular}


A análise estatística realizada pelo Teste de Duas Proporções, apresentada na tabela 24, demonstrou diferença significativa entre os resultados obtidos nos caprinos submetidos a regime intensivo e aqueles em sistema semi- extensivo de criação.

\subsection{Análise dos resultados da prova de imunodifusão em gel de ágar para a Artrite- encefalite dos Caprinos, em animais criados no Estado de São Paulo, distribuídos segundo a ocorrência ou não de artrite.}

O interrelacionamento dos resultados da avaliação clínica e imunológica, para estabelecimento do diagnóstico nosológico da Artrite-encefalite dos Caprinos baseou-se no exame de 1.325 caprinos da população que compôs a amostragem da presente pesquisa. Os resultados obtidos pela prova da imunodifusão em gel de ágar e o diagnóstico clínico de artrite foram distribuídos na tabela 25 .

A forma clínica articular da Artrite-encefalite dos Caprinos, caracterizada principalmente pelo aumento de volume da articulação, além de outros distúrbios do sistema locomotor, como a claudicação e adotar posições anômalas, foi observada em 7,5\% (100/1325) dos animais examinados. Entre estes caprinos 64,0\% (64/100) eram reagentes aos antígenos do vírus da Artrite-encefalite dos Caprinos e 36,0\% (36/100) não estavam infectados.

A utilização do Teste de Duas Proporções demonstrou que, entre caprinos infectados pelo vírus da Artrite-encefalite dos Caprinos, 64\% (64/100) apresentavam manifestações típicas de artrite e 25,3\% (310/1225) dos animais não apresentavam tal sintomatologia, diferença estatisticamente significativa, como 
figurou na tabela 26. O Teste de Duas Proporções demonstrou, também que, a ocorrência de artrite era maior nos caprinos apresentavam a infecção pelo vírus AEC $(17,1$ - 374) do que naqueles que não eram reagentes aos antígenos do referido vírus $(3,8 \%-36 / 951)$.

Tabela 25 - Número de caprinos reagentes e não reagentes à prova da imunodifusão em gel de ágar para a Artrite-encefalite dos Caprinos, segundo a presença ou não de artrite. São Paulo, 2002.

\begin{tabular}{|c|c|c|c|c|c|c|}
\hline \multirow{3}{*}{$\begin{array}{c}\text { Resultados da } \\
\text { Imunodifusão em } \\
\text { gel de ágar }\end{array}$} & \multicolumn{4}{|c|}{ Diagnóstico Nosológico de Artrite } & \multirow{2}{*}{\multicolumn{2}{|c|}{ Total }} \\
\hline & \multicolumn{2}{|c|}{ Com artrite } & \multicolumn{2}{|c|}{ Sem artrite } & & \\
\hline & $\mathbf{N}^{0}$ & $\%$ & $\mathbf{N}^{\mathbf{0}}$. & $\%$ & $\mathbf{N}^{\mathbf{0}}$. & $\%$ \\
\hline Reagentes & 64 & 17,1 & 310 & 82,9 & 374 & 100,0 \\
\hline Não reagentes & 36 & 3,8 & 915 & 96,2 & 951 & 100,0 \\
\hline Total & 100 & 7,5 & 1.225 & 92,5 & 1.325 & 100,0 \\
\hline
\end{tabular}

Tabela 26 - Análise estatística das freqüências de anticorpos antivírus da Artriteencefalite dos Caprinos em animais criados no Estado de São Paulo. Distribuição segundo a presença ou não de artrite. São Paulo, 2002.

\begin{tabular}{|c|c|c|c|}
\hline $1^{\circ}$. Contraste possível & $\begin{array}{c}\text { Amostras sororeagentes } \\
\text { ao VAEC }(\%)\end{array}$ & \begin{tabular}{|c|}
$\begin{array}{c}\text { Valor de } \\
\mathbf{Z}\end{array}$ \\
\end{tabular} & $\begin{array}{c}\text { Significância } \\
\text { estatística }\end{array}$ \\
\hline $\begin{array}{c}\text { Animais Com Artrite } \\
\mathbf{X} \\
\text { Sem Artrite } \\
\end{array}$ & $64,0 \times 25,3$ & $\begin{array}{r}8,268 \\
\end{array}$ & $\mathrm{~S}$ \\
\hline $2^{\circ}$. Contraste possivel & Animais com artrite $(\%)$ & $\begin{array}{c}\text { Valor de } \\
\mathbf{Z}\end{array}$ & $\begin{array}{l}\text { Significância } \\
\text { estatistica }\end{array}$ \\
\hline $\begin{array}{l}\text { Caprinos Nâo Reagentes } \\
X \\
\text { Caprinos Reagentes ao VAEC }\end{array}$ & $3,8 \times 17,1$ & 8,246 & Dos \\
\hline
\end{tabular}




\subsection{Análise dos resultados da prova de imunodifusão em gel de ágar para a Artrite- encefalite dos Caprinos, em cabras criadas no Estado de São Paulo, distribuídos segundo a ocorrência ou não de endurecimento da glândula mamária.}

Os resultados obtidos em soros sangüíneos de cabras criadas no Estado de São Paulo, submetidos à prova de imunodif usão em gel de ágar para detecção de anticorpos antivírus da Artriteencefalite dos Caprinos, considerando a presença ou não de endurecimento da glândula mamária, foram transcritos na Tabela 27.

O exame clínico realizado no momento da colheita das amostras de soro sangüíneo de 499 cabras, permitiram a constatação da ocorrência da forma clínica mamária da Artrite-encefalite dos Caprinos, caracterizada pela presença de nódulos e endurecimento difuso no parênquima da glândula mamária. Das cabras examinadas 4,0\% (20/499) apresentavam à palpação do úbere nódulos no parênquima, e, entre estas cabras $85,0 \%$ (17/20) eram sororeagentes positivas à prova de imunodifusão em gel de ágar para a detecção de anticorpos antivírus AEC.

Fato digno de realce foi a observação, que dessas cabras examinadas, 1,8\% (9/499) apresentavam simultaneamente, a forma clínica mamária e a articular da Artrite-encefalite dos Caprinos, dos quais $88,9 \%(8 / 9)$ eram sororeagentes ao mencionado vírus. 
Tabela 27 - Número de cabras reagentes e não reagentes à prova da imunodifusão em gel de ágar para a Artrite-encefalite dos Caprinos. Distribuição segundo a presença ou não de endurecimento da glândula mamária. Resultados expressos em valores absolutos e relativos. São Paulo, 2002 .

\begin{tabular}{l|cc|cc|cc}
\hline \multirow{2}{*}{$\begin{array}{c}\text { Resultados da } \\
\text { Imunodifusão em } \\
\text { gel de ágar }\end{array}$} & \multicolumn{2}{c|}{ Endurecimento da Glândula Mamária } & \multicolumn{2}{c}{ Total } \\
\cline { 2 - 7 } & \multicolumn{2}{|c|}{ Presente } & \multicolumn{2}{c}{ Ausente } & & \\
\cline { 2 - 7 } & $\mathbf{N}^{\mathbf{0}}$. & $\mathbf{\%}$ & $\mathbf{N}^{\mathbf{0}}$ & $\mathbf{\%}$ & $\mathbf{N}^{\mathbf{0}}$. & $\mathbf{\%}$ \\
\hline Reagentes & 17 & 6,8 & 232 & 93,2 & 249 & 100,0 \\
Não reagentes & 3 & 1,2 & 247 & 98,8 & 250 & 100,0 \\
\hline Total & $\mathbf{2 0}$ & $\mathbf{4 , 0}$ & $\mathbf{4 7 9}$ & $\mathbf{9 6 , 0}$ & $\mathbf{4 9 9}$ & $\mathbf{1 0 0 , 0}$ \\
\hline
\end{tabular}

Tabela 28 - Análise estatística das freqüências de anticorpos antivírus da Artriteencefalite dos Caprinos determinadas em animais criados no Estado de São Paulo, distribuídos segundo a presença ou não de endurecimento da glândula mamária. São Paulo, 2002.

\begin{tabular}{|c|c|c|c|}
\hline $1^{\circ}$. Contraste possivel & $\begin{array}{l}\text { Amostras } \\
\text { sororeagentes ao } \\
\text { VAEC (\%) } \\
\end{array}$ & $\begin{array}{c}\text { Valor de } \\
Z\end{array}$ & $\begin{array}{l}\text { Significância } \\
\text { estatística }\end{array}$ \\
\hline $\begin{array}{c}\text { Cabras com } \\
X \\
\text { Cabras sem endurecimento da } \\
\text { glândula mamária }\end{array}$ & $85,0 \times 48,4$ & 3,207 & $\mathrm{~S}$ \\
\hline $2^{\circ}$. Contraste possivel & $\begin{array}{l}\text { Animais com } \\
\text { endurecimento da } \\
\text { glândula mamária }(\%)\end{array}$ & $\begin{array}{c}\text { Valor de } \\
\mathbf{Z}\end{array}$ & $\begin{array}{l}\text { Significáncia } \\
\text { estatistica }\end{array}$ \\
\hline $\begin{array}{c}\text { Cabras Reagentes } \\
\mathbf{X} \\
\text { Cabras Não Reagentes ao VAEC }\end{array}$ & $6,8 \times 1,2$ & 3,194 & $\mathbf{S}$ \\
\hline
\end{tabular}

Teste de Duas Proporções: Valor de Z crítico $=1,96$.

$\mathrm{S}=$ significante.

$\mathrm{Na}$ tabela 28 , foram apresentados os resultados da análise estatística, avaliando-se as duas possibilidades de contraste comparando os valores determinados para a ocorrência ou não da forma clínica mamária da Artriteencefalite dos Caprinos e a freqüência de cabras sororeagentes positivas aos 
antígenos do vírus determinante da mencionada enfermidade. Houve duas possibilidades de se fazerem as avaliações, segundo os contrastes: comparando o número de caprinos com sinais evidentes de endurecimento do úbere, em consideração ao número de caprinos reagentes e não reagentes ao vírus AEC. A utilização do Teste de Duas Proporções demonstrou que, a freqüência da infecção pelo vírus da AEC, foi significativamente maior nos animais que apresentavam endurecimento da glândula mamária $(85 \%$ - 17/20) do que naqueles que não apresentavam a forma clínica mamária da referida virose (48,4\% - 232/479). O Teste de Duas Proporções demonstrou, também que, a ocorrência do endurecimento da glândula mamária era maior nas cabras que apresentavam a infecção pelo vírus $\operatorname{AEC~}(6,8 \%$ - 17/249) do que naquelas que não eram reagentes aos antígenos do referido vírus $(1,2 \%-3 / 250)$.

\subsection{Resultados da prova de imunodifusão em gel de ágar para a Artrite- encefalite dos Caprinos, para avaliar a transmissibilidade do vírus pelo aleitamento de cabritos neonatos.}

Na tabela 29 foram dispostos os resultados da prova de imunodifusão em gel de ágar para detecção de anticorpos antivírus da Artrite-encefalite dos Caprinos, realizada nas amostras de soro sangüíneo colhidas dos 51 caprinos jovens criados no CPDER - VCM - FMVZ - USP, com três diferentes tipos de aleitamento, até os 180 dias de idade. 


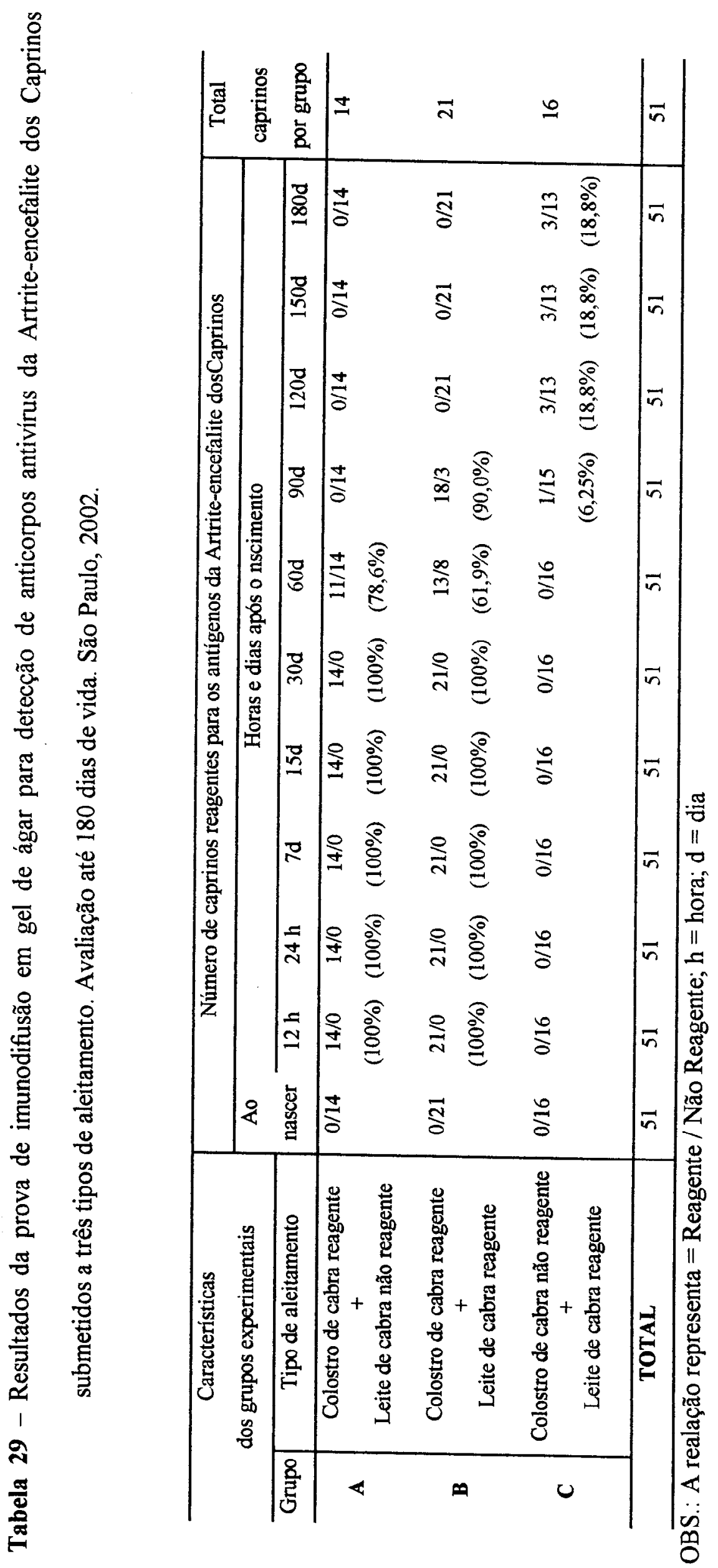


⿷匚

율 융

0

㥕

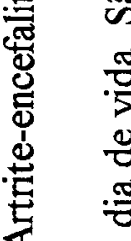

च

를

.

\%

兽 总

용

요 움

胥 罚

$\infty$

해

त)

유

\&

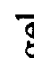

छ

蛋

冚 密

总

园

ว

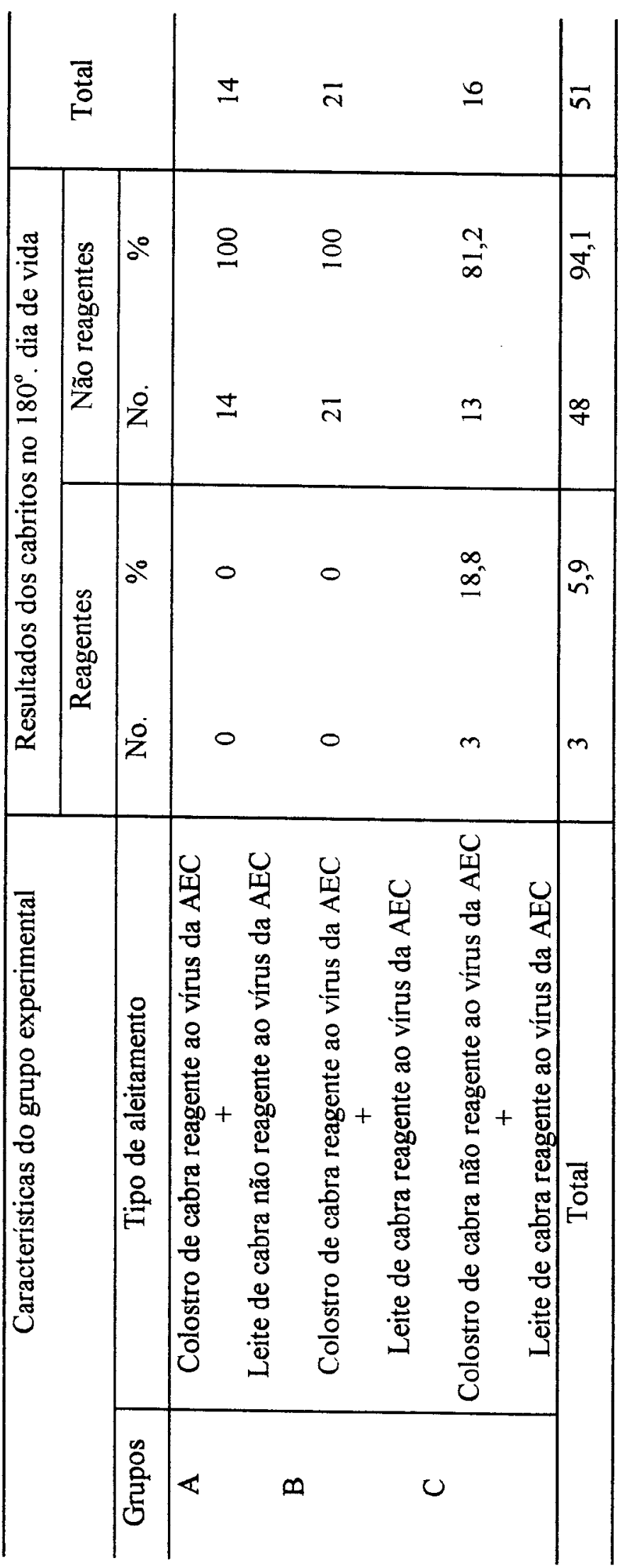


A figura 8 ilustra a soroconversão dos caprinos do GRUPO A, como detalhado nas tabelas 29 e 30, que receberam colostro de cabras soropositivas e aleitamento com leite de cabras soronegativas ao vírus da Artrite-encefalite dos Caprinos. Todos os cabritos foram soronegativos ao nascerem (antes de mamarem o colostro de cabras sororeagentes positivas), e se tornaram soropositivos imediatamente após mamarem o colostro de cabras infectadas pelo já mencionado vírus. Aos 60 dias de vida 78,6\% (11/14) dos cabritos se tornaram soronegativos e aos 90 dias todos se tornaram soronegativos, não apresentando mais os anticorpos virais passivamente transferidos pela ingestão de colostro, permanecendo assim até os 180 dias de idade, quando se finalizou o período experimental estipulado pelo delineamento experimental.

Na figura 9 e tabelas 29 e 30 demonstrou-se a soroconversão dos animais do GRUPO B, ou seja os que receberam colostro e leite de cabras soropositivas ao vírus da Artrite-encefalite dos Caprinos. Estes resultados demonstraram, mais uma vez que $100 \%$ dos cabritos nasceram soronegativos ao referido vírus e após mamarem o colostro (de cabras infectadas) tornaram-se soropositivos. Mas aos 60 dias de vida 61,9\% (13/21) dos cabritos tornaram-se soronegativos, aos 90 dias de idade $90, \%(18 / 21)$ eram soronegativos e finalmente aos 120 dias de idade $100 \%$ dos cabritos não apresentavam mais anticorpos antivírus da Artrite-encefalite dos Caprinos no sangue circulante, e não reagentes permaneceram até o término do período experimental aos 180 dias de vida dos cabritos.

Os resultados dos soros sangüíneos oriundos dos cabritos que instituíram o GRUPO C, isto é, que receberam colostro de cabras soronegativas e 
leite de cabras soropositivas ao vírus da Artrite-encefalite dos Caprinos, demonstraram que três cabritos se tornaram sororeagentes ao final do período experimental, sendo que desses, um soroconverteu aos 90 dias de idade e outros dois cabritos aos 120 dias de idade, como demonstrou-se nas tabelas 28 e 29 e ilustrou-se na figura 10.

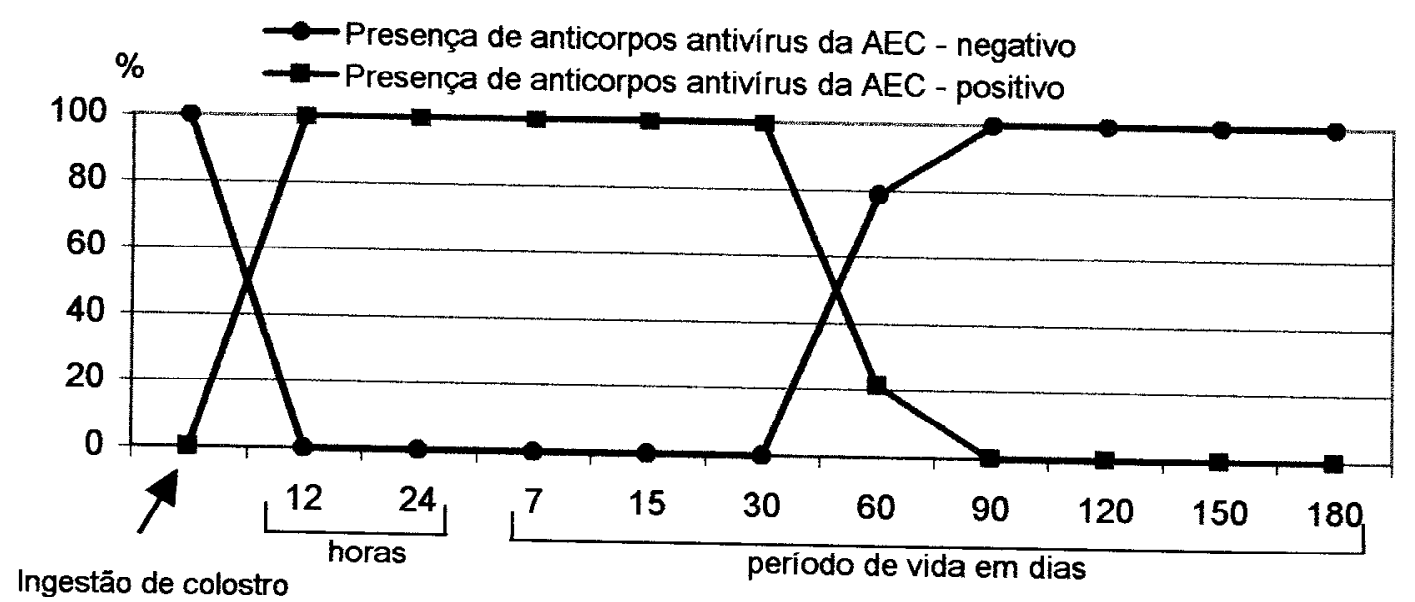

Figura 8 - Distribuição da freqüência de cabritos sororeagentes ou não ao vírus da Artrite-encefalite dos Caprinos, do GRUPO-A: em amostras de soro de cabritos que receberam colostro de cabras soropositivas e leite de cabras soronegativas. São Paulo, 2002.

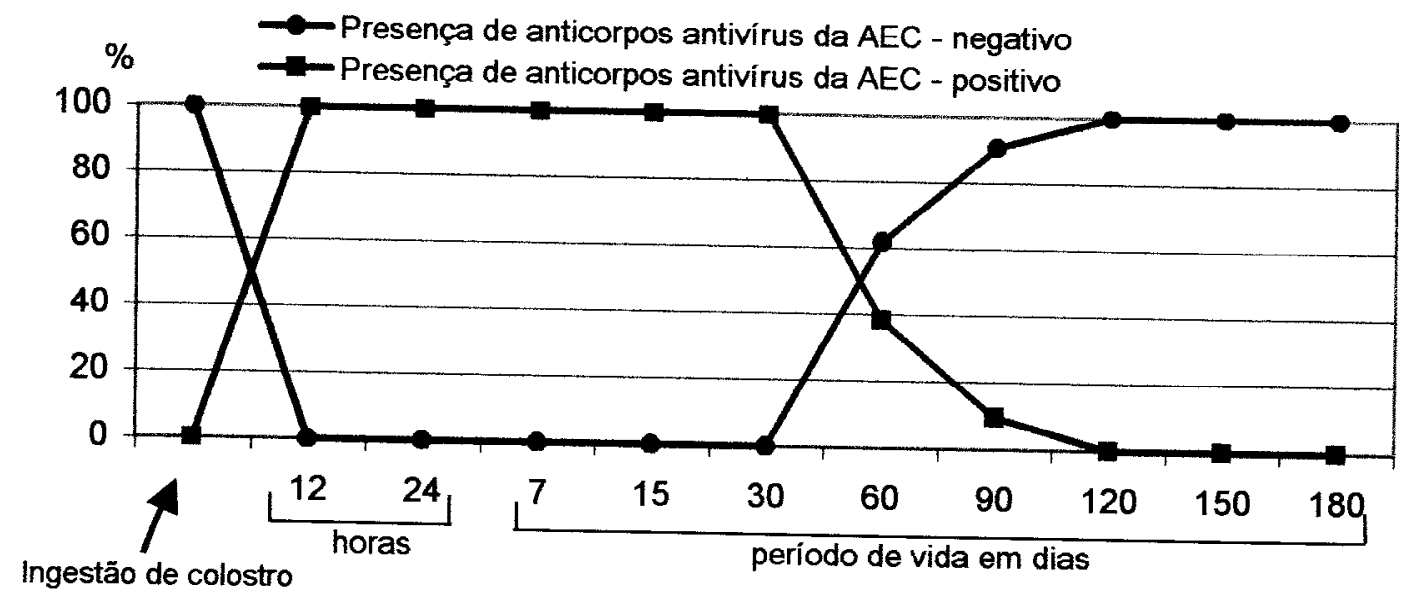

Figura 9 - Distribuição da freqüência de cabritos sororeagentes ou não ao vírus da Artrite-encefalite dos Caprinos, do GRUPO-B: em amostras de soro de cabritos que receberam colostro e leite de cabras soropositivas. São Paulo, 2002. 


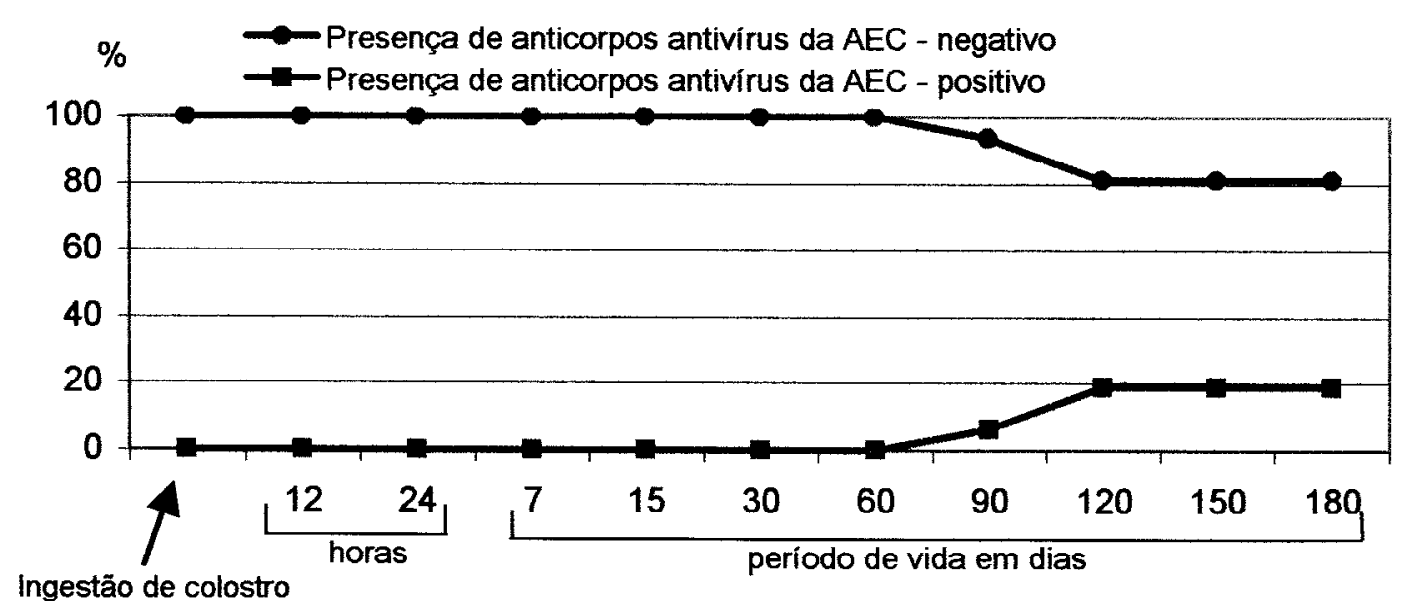

Figura 10 - Distribuição da freqüência de cabritos, sororeagentes ou não ao vírus da Artrite-encefalite dos Caprinos, do GRUPO-C: em amostras de soro de cabritos que receberam colostro de cabras soronegativas e leite de cabras soropositivas. São Paulo, 2002.

4.10 Resultados da prova de imunodifusão em gel de ágar para a Artriteencefalite dos Caprinos, em cabritos recém-nascidos, para avaliar a possibilidade de transmissão transplacentária do vírus.

Para avaliar a possibilidade da transmissão vertical ou transplacentária do vírus da Artrite-encefalite dos Caprinos foram considerados os resultados da prova da imunodifusão em gel de ágar para o vírus da AEC em 26 cabritos neonatos, oriundos de parturição natural de cabras infectadas pelo mencionado vírus, nascidos e criados no Centro de Pesquisa e Diagnóstico de Enfermidades dos Ruminantes - CPDER do Departamento de Clínica Médica da FMVZ-USP. Destes animais foram colhidas amostras de soro sangüíneo, imediatamente, ao nascerem e pôde-se constatar que 100\% (26/26) nasceram sem que pudesse comprovar em amostras de soro sangüíneo a presença de anticorpos antivírus da Artrite-encefalite dos Caprinos, como demonstraram os resultados da tabela 31 . 
Tabela 31 - Resultados da prova de imunodifusão em gel de ágar (IDGA) para a detecção de anticorpos antivírus da Artrite-encefalite dos Caprinos, em cabritos neonatos, nascidos de partos eutócicos de cabras infectadas antes da ingestão do colostro. São Paulo, 2002.

\begin{tabular}{|c|c|c|c|c|c|c|c|c|}
\hline \multirow{4}{*}{$\begin{array}{l}\text { Cabritos } \\
\text { Recém-nascidos }\end{array}$} & \multicolumn{8}{|c|}{ Resultados de IDGA para Artrite-encefalite dos Caprinos } \\
\hline & \multicolumn{4}{|c|}{ Antes da Ingestão do Colostro } & \multicolumn{4}{|c|}{ Aos 180 dias de vida } \\
\hline & \multicolumn{2}{|c|}{ Reagentes } & \multicolumn{2}{|c|}{ Não Reagentes } & \multicolumn{2}{|c|}{ Reagentes } & \multicolumn{2}{|c|}{ Não Reagentes } \\
\hline & $\mathbf{N}^{0}$. & $\%$ & $\mathbf{N}^{\mathbf{0}}$. & $\%$ & $\mathbf{N}^{\mathbf{0}}$. & $\%$ & $\mathbf{N}^{\mathbf{0}}$. & $\%$ \\
\hline 26 & 0 & 0 & 26 & 100 & 0 & 0 & 26 & 100 \\
\hline Total & -- & -- & 26 & 100 & - & - & 26 & 100 \\
\hline
\end{tabular}

IDGA = Imunodifusão em gel de ágar

4.11 Resultados da prova de imunodifusão em gel de ágar para a Artriteencefalite dos Caprinos, de amostras de soro sangüineos de animais inoculados com amostras de colostro, leite e sangue de caprinos infectados.

Os resultados da prova de imunodifusão para a Artrite-encefalite dos Caprinos nos soros sangüíneos dos 15 caprinos inoculados com colostro, leite e sangue infectados pelo vírus da Artrite-encefalite dos Caprinos, foram detalhados na tabela 32, segundo o inóculo que receberam e a via de inoculação. Para melhor visualização do momento de soroconversão dos caprinos durante a fase experimental os resultados obtidos pela prova de imunodifusão foram ilustrados nas figuras 11,12 e 13 e os obtidos pelo teste de ELISA estão demonstrados nas figuras 14, 15 e 16 . 


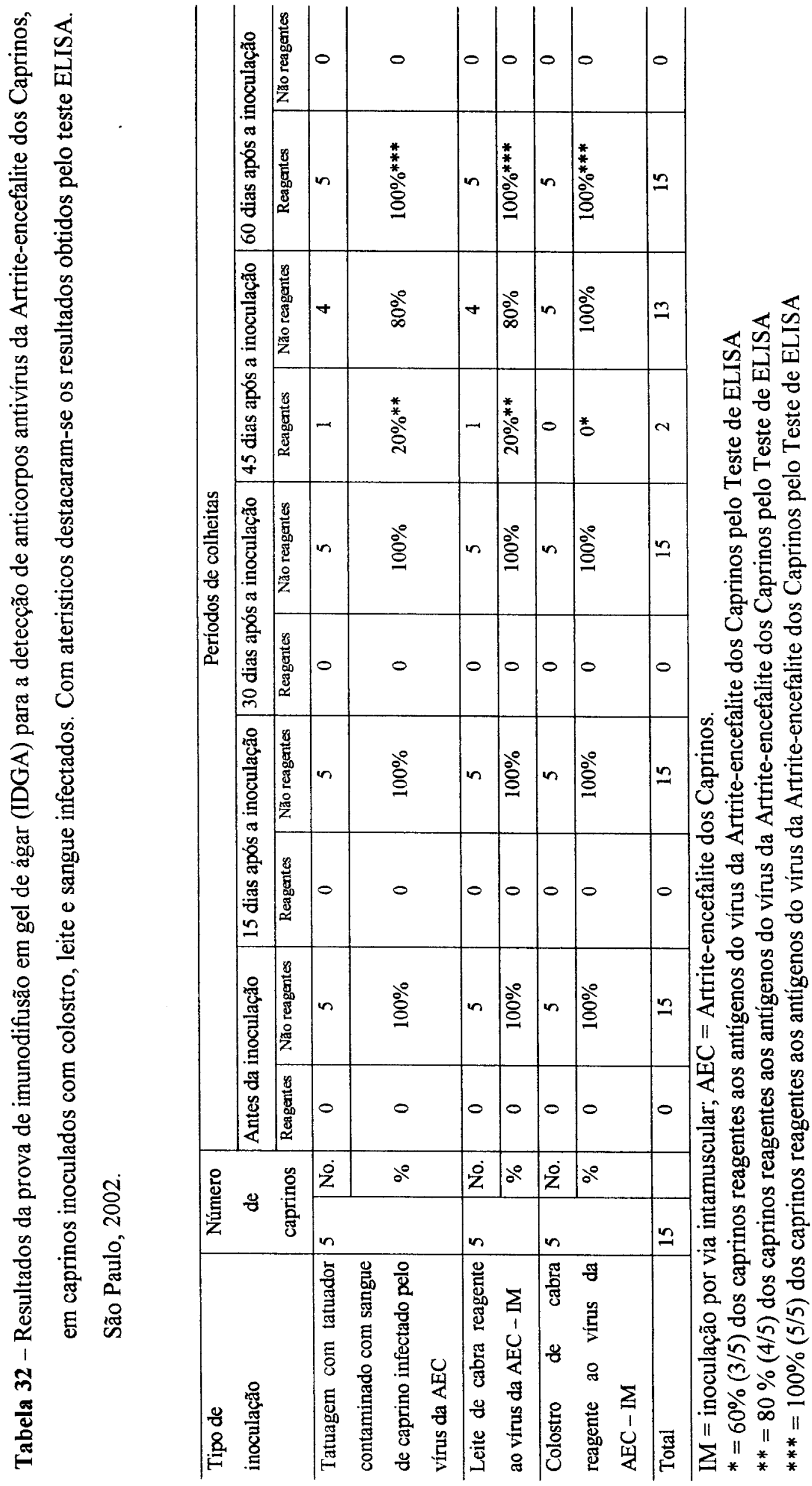




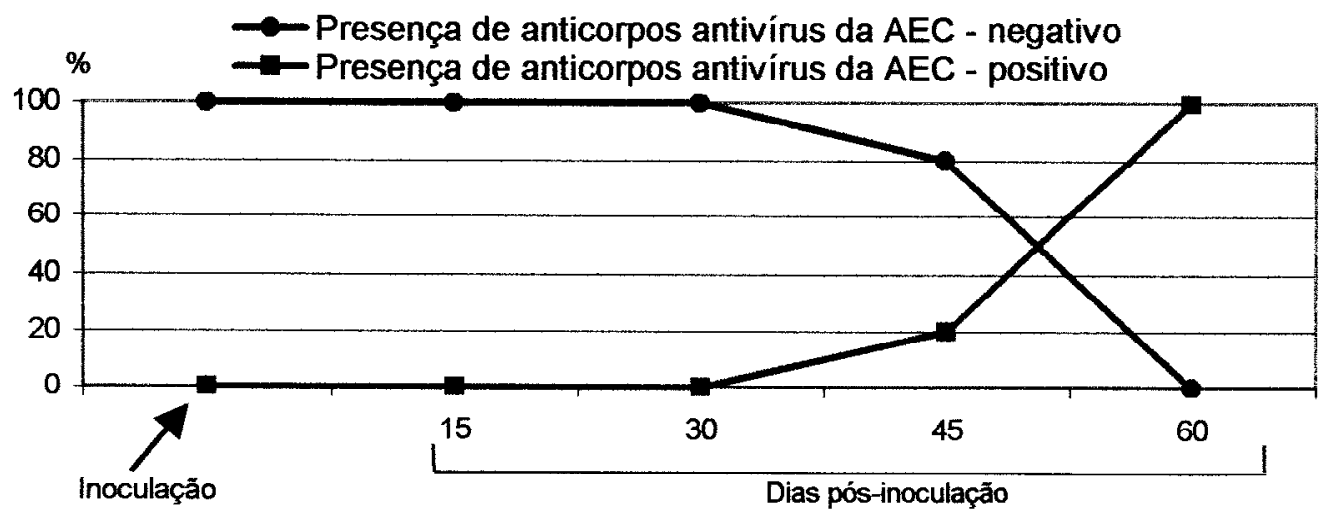

Figura 11 - Distribuição da freqüência de animais sororeagentes ou não ao vírus da Artrite-encefalite dos Caprinos: em amostras de soro de cabritos inoculados por tatuagens executadas com equipamento contaminado com sangue infectado pelo vírus da AEC. Determinação pela prova da imunodifusão em gel de ágar. São Paulo, 2002.

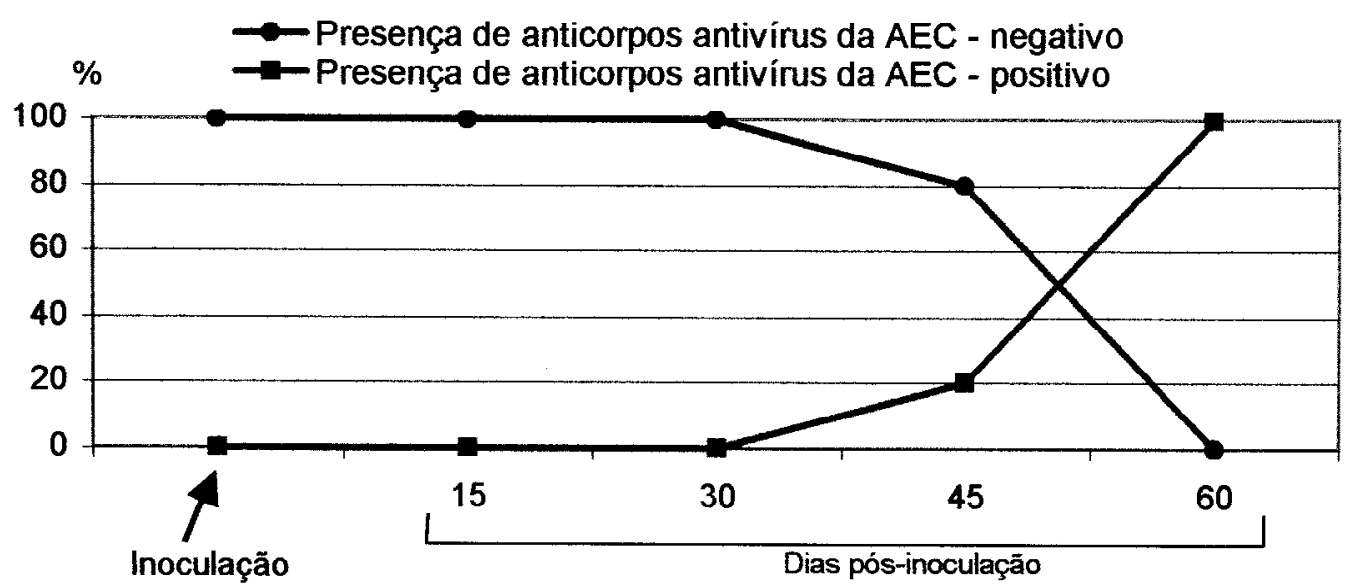

Figura 12 - Distribuição da freqüência de animais sororeagentes ou não ao vírus da Artrite-encefalite dos Caprinos: em amostras de soro de cabritos inoculados por via intramuscular com leite oriundo de cabras sororeagente ao vírus da AEC. Determinação pela prova da imunodifusão em gel de ágar. São Paulo, 2002. 


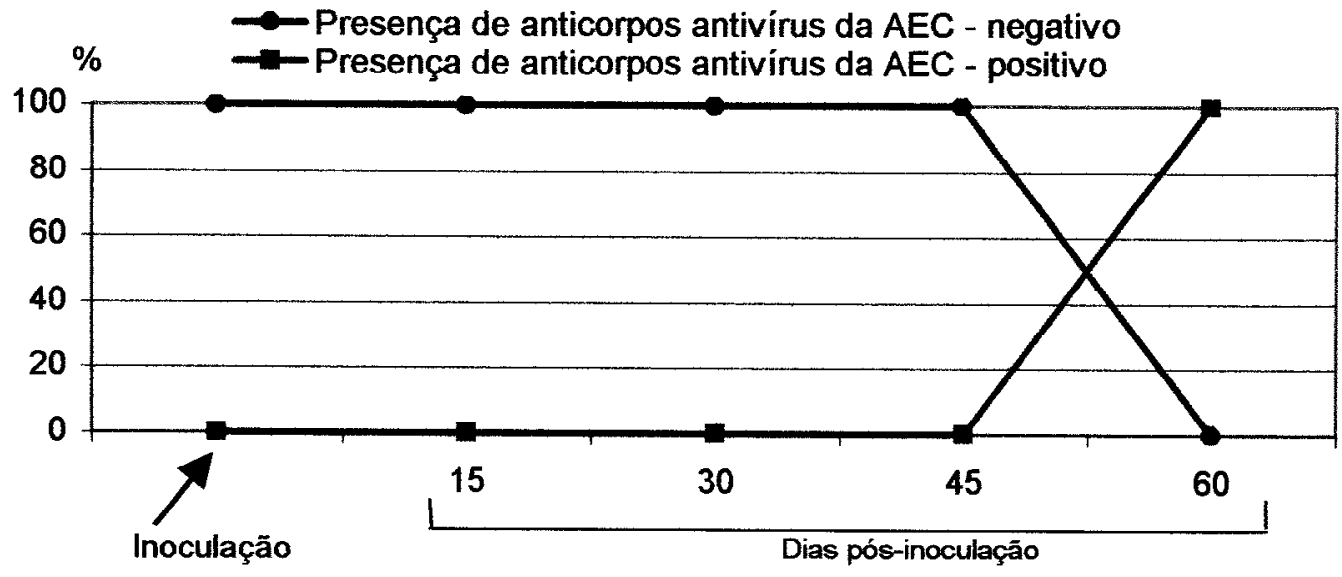

Figura 13 - Distribuição da freqüência de animais sororeagentes ou não ao vírus da Artrite-encefalite dos Caprinos: em amostras de soro de cabritos inoculados por via intramuscular com colostro oriundo de cabras sororeagente ao vírus da AEC. Determinação pela prova da imunodifusão em gel de ágar. São Paulo, 2002.

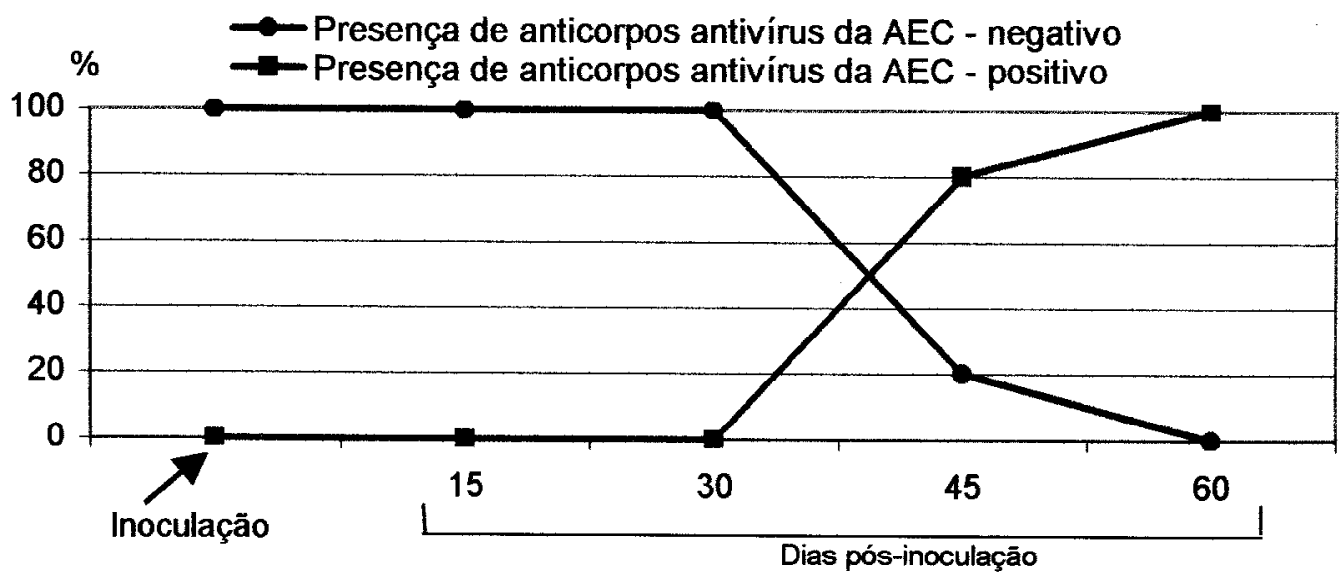

Figura 14 - Distribuição da freqüência de animais sororeagentes ou não ao vírus da Artrite-encefalite dos Caprinos: em amostras de soro de cabritos inoculados por tatuagens executadas com equipamento contaminado com sangue infectado pelo vírus da AEC. Determinação pelo teste ELISA. São Paulo, 2002. 


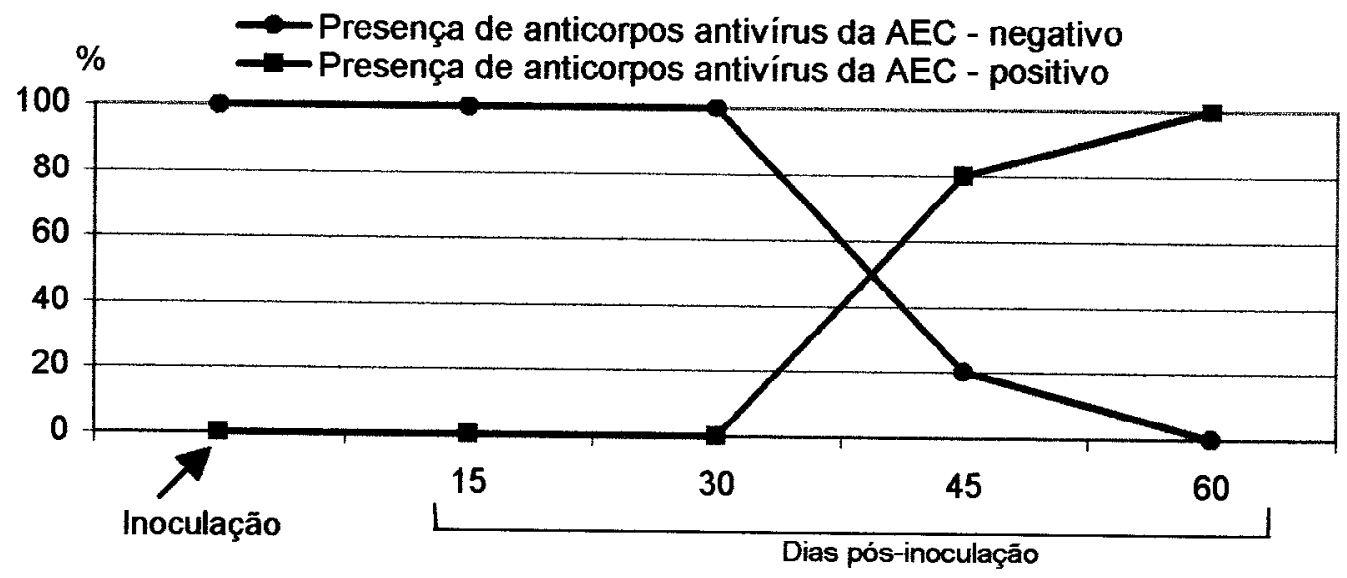

Figura 15 - Distribuição da freqüência de animais sororeagentes ou não ao vírus da Artrite-encefalite dos Caprinos: em amostras de soro de cabritos inoculados por via intramuscular com leite oriundo de cabras sororeagente ao vírus da AEC. Determinação pelo teste ELISA. São Paulo, 2002.

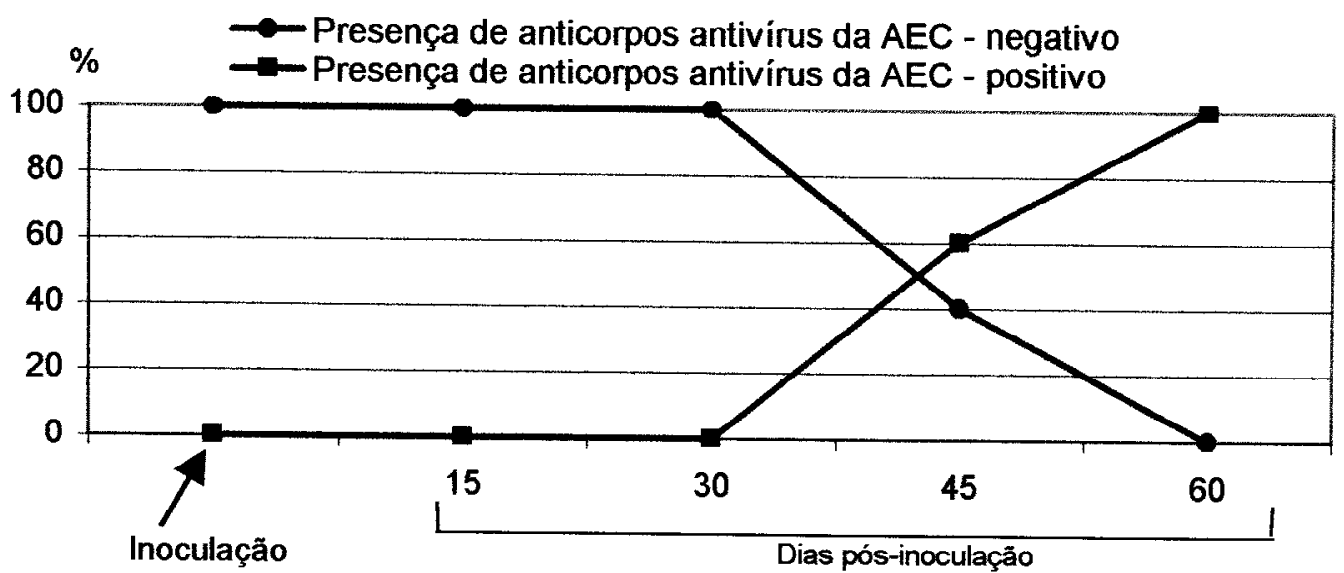

Figura 16 - Distribuição da freqüência de animais sororeagentes ou não ao vírus da Artrite-encefalite dos Caprinos: em amostras de soro de cabritos inoculados por via intramuscular com colostro oriundo de cabras sororeagente ao vírus da AEC. Determinação pelo teste ELISA. São Paulo, 2002.

Com a utilização da técnica de imunodifusão, pôde-se constatar, como foi delineado, nas figuras 11 e 12 que no grupo de animais inoculados, tanto, 
Com a utilização da técnica de imunodifusão, pôde-se constatar, como foi delineado, nas figuras 11 e 12 que no grupo de animais inoculados, tanto, pelas tatuagens executadas com tatuador contaminado com sangue infectado, como por via intramuscular com leite proveniente de cabra sororeagente ao vírus da $\mathrm{AEC}$; desses cabritos $20,0 \%(1 / 5)$ dos espécimes se tornaram soropositivos 45 dias após a inoculação. Os demais caprinos tornaram-se soropositivos aos 60 dias pós inoculação. A apreciação dos resultados delineados na figura 13 demonstrou que dos caprinos inoculados por via intramuscular com colostro proveniente de cabra soropositiva, todos os animais soroconverteram 60 dias após a inoculação.

Por outro lado, com o auxílio do teste imunoenzimático (ELISA), demonstrou-se que a soroconversão foi mais precoce, pois verificou-se, que $80 \%$ (4/5) dos caprinos inoculados com leite pela via intramuscular, como também aqueles inoculados com sangue pela utilização do tatuador, puderam ter anticorpos séricos detectados 45 dias após ter sido realizada a inoculação e, com 60 dias, todos os animais tornaram-se soropositivos. No grupo dos caprinos inoculados com colostro por via intramuscular, $60 \%$ (3/5) apresentavam anticorpos séricos antivírus da Artrite-encefalite, 45 dias após as inoculações. Com 60 dias pós inoculação todos os caprinos deste grupo experimental tornaram-se sororeagentes. 


\subsection{Transferência de imunidade passiva por ingestão de colostro - Resultados da concetração de proteína total, gamaglobulina e gamaglutamiltransferase séricas de cabritos, crias de cabras soropositivas e soronegativas ao vírus da Artrite-encefalite dos Caprinos, desde o nascimento até 180 dias de idade.}

Os resultados obtidos para as concentrações séricas de proteína total, gamaglobulina e gamaglutamiltransferase, observados em cabritos filhos de cabras soronegativas e soropositivas ao vírus da Artrite-encefalite dos Caprinos, desde o nascimento até os 180 dias de idade, associados aos elementos de estatística descritiva (média e desvio padrão), foram apresentados nas tabelas 33, 34 e 35. Os resultados apresentados nas tabelas 33, 34, 35 e figuras 17, 18, 19 demonstraram, que ao nascerem os cabritos tinham semelhantes teores séricos de proteína total, gamaglobulinas e de atividade da enzima glutamiltransferase nos dois grupos experimentais: cabritos crias de cabras infectadas ou não infectadas pelo vírus causador da Artrite-encefalite dos Caprinos. Após a ingestão do colostro observou-se aumento de maior magnitude nos teores séricos de proteína total da fração gamaglobulina no grupo de cabritos crias de cabras soropositivas para o vírus AEC. Semelhante variação observou-se também para a atividade sérica da enzima glutamiltransferase. Essa diferença como aquela observada entre os valores séricos de gamaglobulina foram estatisticamente significativas. Após 24 horas da ingestão do colostro ambos valores diminuíram e suas magnitudes passaram a se equivalerem. As variações dos valores séricos que demonstraram a transferência de imunidade passiva para os cabritos após a ingestão do colostro foram mais elucidativas na visualização das figuras 18 e-19. 
Tabela 33 - Valores médios (x) e desvios padrão(s) obtidos para os teores de proteína total sérica $(\mathrm{g} / \mathrm{dl})$ em cabritos crias de cabras soronegativas e soropositivas ao vírus da Artrite-encefalite dos Caprinos, agrupados de acordo com a idade, do nascimento - antes da ingestão de colostro - até os 180 dias de vida. São Paulo, 2002.

\begin{tabular}{|c|c|c|c|c|c|}
\hline \multirow[b]{2}{*}{ Aleitamento } & \multirow{2}{*}{$\begin{array}{l}\text { Tempo de } \\
\text { vida em } \\
\text { horas ou } \\
\text { dias }\end{array}$} & \multicolumn{4}{|c|}{ Proteína Total Sérica (g/dl) } \\
\hline & & $\begin{array}{c}N^{\circ} \text {. de } \\
\text { animais }\end{array}$ & 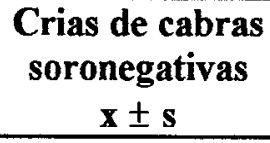 & $\begin{array}{c}\mathbf{N}+\text {. de } \\
\text { animais }\end{array}$ & $\begin{array}{c}\text { Crias de cabras } \\
\text { soropositivas } \\
x \pm s \\
\end{array}$ \\
\hline $\begin{array}{ll}\text { Antes } & \text { da } \\
\text { ingestão } & \text { de } \\
\text { colostro } & \\
\end{array}$ & 0 horas & 15 & $3,73 \pm 0,61^{a^{*}}$ & 24 & $3,75 \pm 0,41^{2}$ \\
\hline Leite & $\begin{array}{c}12 \text { horas } \\
24 \text { horas } \\
7 \text { dias } \\
15 \text { dias } \\
30 \text { dias } \\
60 \text { dias } \\
90 \text { dias } \\
120 \text { dias } \\
150 \text { dias } \\
180 \text { dias } \\
\end{array}$ & $\begin{array}{c}9 \\
13 \\
5 \\
7 \\
7 \\
14 \\
9 \\
7 \\
12 \\
10 \\
\end{array}$ & $\begin{array}{l}6,97 \pm 1,28^{\mathrm{a}} \\
6,81 \pm 1,45^{\mathrm{a}} \\
5,74 \pm 1,45^{\mathrm{a}} \\
5,54 \pm 0,52^{\mathrm{a}} \\
4,95 \pm 0,51^{\mathrm{a}} \\
5,37 \pm 0,45^{\mathrm{a}} \\
5,79 \pm 0,45^{\mathrm{a}} \\
6,17 \pm 0,63^{\mathrm{a}} \\
6,30 \pm 0,63^{\mathrm{a}} \\
5,84 \pm 0,70^{\mathrm{a}} \\
\end{array}$ & $\begin{array}{c}18 \\
19 \\
19 \\
13 \\
4 \\
6 \\
13 \\
4 \\
13 \\
14\end{array}$ & $\begin{array}{l}6,01 \pm 1,11^{\mathrm{a}} \\
6,15 \pm 1,08^{\mathrm{a}} \\
5,37 \pm 1,00^{\mathrm{a}} \\
5,32 \pm 0,92^{\mathrm{a}} \\
5,13 \pm 0,32^{\mathrm{a}} \\
5,16 \pm 0,28^{\mathrm{a}} \\
5,41 \pm 0,67^{\mathrm{a}} \\
6,19 \pm 0,58^{\mathrm{a}} \\
6,23 \pm 1,02^{\mathrm{a}} \\
6,05 \pm 0,70^{\mathrm{a}}\end{array}$ \\
\hline
\end{tabular}

* Médias com letras não coincidentes denotam diferença significativa $-\alpha=0,05$

$\mathrm{x} \pm \mathrm{s}=$ valor médio \pm desvio padrão

Tabela 34 - Valores médios (x) e desvios padrão (s) obtidos para os teores de gamaglobulina sérica $(\mathrm{g} / \mathrm{dl})$ em cabritos crias de cabras soronegativas e soropositivas ao vírus da Artrite-encefalite dos Caprinos, agrupados de acordo com a idade, do nascimento - antes da ingestão de colostro - até os 180 dias de vida. São Paulo, 2002.

\begin{tabular}{|c|c|c|c|c|c|}
\hline \multirow[b]{2}{*}{ Aleitamento } & \multirow{2}{*}{$\begin{array}{c}\text { Tempo } \\
\text { de vida } \\
\text { em } \\
\text { horas ou } \\
\text { dias } \\
\end{array}$} & \multicolumn{4}{|c|}{ Gamaglobulina Sérica (g/dl) } \\
\hline & & $\begin{array}{c}\mathbf{N}^{\circ} \text {. de } \\
\text { animais }\end{array}$ & $\begin{array}{c}\text { Crias de cabras } \\
\text { soronegativas } \\
x \pm s\end{array}$ & $\begin{array}{l}\mathbf{N}^{\mathbf{o}} \text {. de } \\
\text { animais }\end{array}$ & $\begin{array}{c}\text { Crias de cabras } \\
\text { soropositivas } \\
\quad x \pm s\end{array}$ \\
\hline \multirow[t]{2}{*}{$\begin{array}{l}\text { Antes da ingestão } \\
\text { de colostro }\end{array}$} & 0 horas & 15 & $0,39 \pm 0,13^{\mathrm{a}^{*}}$ & 24 & $0,48 \pm 0,24^{3}$ \\
\hline & 12 horas & 9 & $3,01 \pm 1,27^{\mathrm{a}}$ & 18 & $2,10 \pm 0,90^{b}$ \\
\hline \multirow[t]{9}{*}{ Leite } & 24 horas & 13 & $2,82 \pm 1,24^{a}$ & 19 & $2,24 \pm 0,96^{\mathrm{a}}$ \\
\hline & 7 dias & 5 & $1,90 \pm 1,06^{2}$ & 19 & $1,31 \pm 0,55^{\mathrm{a}}$ \\
\hline & 15 dias & 7 & $1,51 \pm 0,46^{\mathrm{a}}$ & 13 & $0,97 \pm 0,22^{b}$ \\
\hline & 30 dias & 7 & $1,07 \pm 0,45^{a}$ & 4 & $0,78 \pm 0,17^{\mathrm{a}}$ \\
\hline & 60 dias & 14 & $1,08 \pm 0,35^{a}$ & 6 & $1,05 \pm 0,23^{a}$ \\
\hline & 90 dias & 9 & $1,19 \pm 0,50^{\mathrm{a}}$ & 13 & $1,04 \pm 0,23^{a}$ \\
\hline & 120 dias & 7 & $1,21 \pm 0,18^{\mathrm{a}}$ & 4 & $1,48 \pm 0,29^{\mathrm{a}}$ \\
\hline & 150 dias & 12 & $1,41 \pm 0,35^{\mathrm{a}}$ & 13 & $1,61 \pm 0,50^{\mathrm{a}}$ \\
\hline & 180 dias & 10 & $1,54 \pm 0,24^{2}$ & 14 & $1,53 \pm 0,35^{\mathrm{a}}$ \\
\hline
\end{tabular}

* Médias com letras não coincidentes denotam diferença significativa $-\alpha=0,05$

$\mathrm{x} \pm \mathrm{s}=$ valor médio \pm desvio padrão 
Tabela 35 - Valores médios (x) e desvios padrão (s) obtidos para os teores de gamaglutamiltransferase sérica (UI/l) em cabritos filhos de mães soronegativas e soropositivas ao vírus da Artrite-encefalite dos Caprinos, agrupados de acordo com a idade, do nascimento - antes da ingestão de colostro - até os 180 dias de vida. São Paulo, 2002.

\begin{tabular}{|c|c|c|c|c|c|}
\hline \multirow[b]{2}{*}{ Aleitamento } & \multirow{2}{*}{$\begin{array}{l}\text { Tempo de } \\
\text { vida em } \\
\text { horas ou } \\
\text { dias }\end{array}$} & \multicolumn{4}{|c|}{ Gamaglutamiltransferase (UI/) } \\
\hline & & $\begin{array}{c}N^{\circ} \text {. de } \\
\text { animais }\end{array}$ & $\begin{array}{c}\text { Crias de cabras } \\
\text { soronegativas } \\
x \pm s \\
\end{array}$ & $\begin{array}{c}\mathbf{N}^{\mathbf{o}} \text {. de } \\
\text { animais }\end{array}$ & $\begin{array}{c}\text { Crias de cabras } \\
\text { soropositivas } \\
\mathbf{x} \pm \mathbf{s}\end{array}$ \\
\hline \multirow{2}{*}{$\begin{array}{ll}\text { Antes } & \text { da } \\
\text { ingestão } & \text { de } \\
\text { colostro } & \end{array}$} & 0 horas & 15 & $19,30 \pm 3,73^{a^{*}}$ & 24 & $23,65 \pm 11,47^{\mathrm{a}}$ \\
\hline & 12 horas & 9 & $467,62 \pm 260,67^{\mathrm{a}}$ & 18 & $265,89 \pm 130,30^{b}$ \\
\hline \multirow[t]{9}{*}{ Leite } & 24 horas & 13 & $247,22 \pm 96,09^{a}$ & 19 & $265,16 \pm 139,23^{a}$ \\
\hline & 7 dias & 5 & $61,08 \pm 27,18^{a}$ & 19 & $56,44 \pm 19,14^{\mathrm{a}}$ \\
\hline & 15 dias & 7 & $44,54 \pm 15,77^{\mathrm{a}}$ & 13 & $42,77 \pm 13,08^{a}$ \\
\hline & 30 dias & 7 & $25,41 \pm 2,50^{\mathrm{a}}$ & 4 & $23,44 \pm 3,90^{\mathrm{a}}$ \\
\hline & 60 dias & 14 & $25,92 \pm 4,13^{a}$ & 6 & $32,87 \pm 17,54^{\mathrm{a}}$ \\
\hline & 90 dias & 9 & $23,39 \pm 3,21^{\mathrm{a}}$ & 13 & $26,04 \pm 7,46^{\mathrm{a}}$ \\
\hline & 120 dias & 7 & $24,55 \pm 3,37^{\mathrm{a}}$ & 4 & $26,77 \pm 2,72^{a}$ \\
\hline & 150 dias & 12 & $24,36 \pm 4,08^{a}$ & 13 & $32,82 \pm 7,12^{b}$ \\
\hline & 180 dias & 10 & $22,48 \pm 3,41^{a}$ & 14 & $29,20 \pm 12,36^{\mathrm{a}}$ \\
\hline
\end{tabular}

* Médias com letras não coincidentes denotam diferença significativa $-\alpha=0,05$

$\mathrm{X} \pm \mathrm{s}=$ valor médio \pm desvio padrão

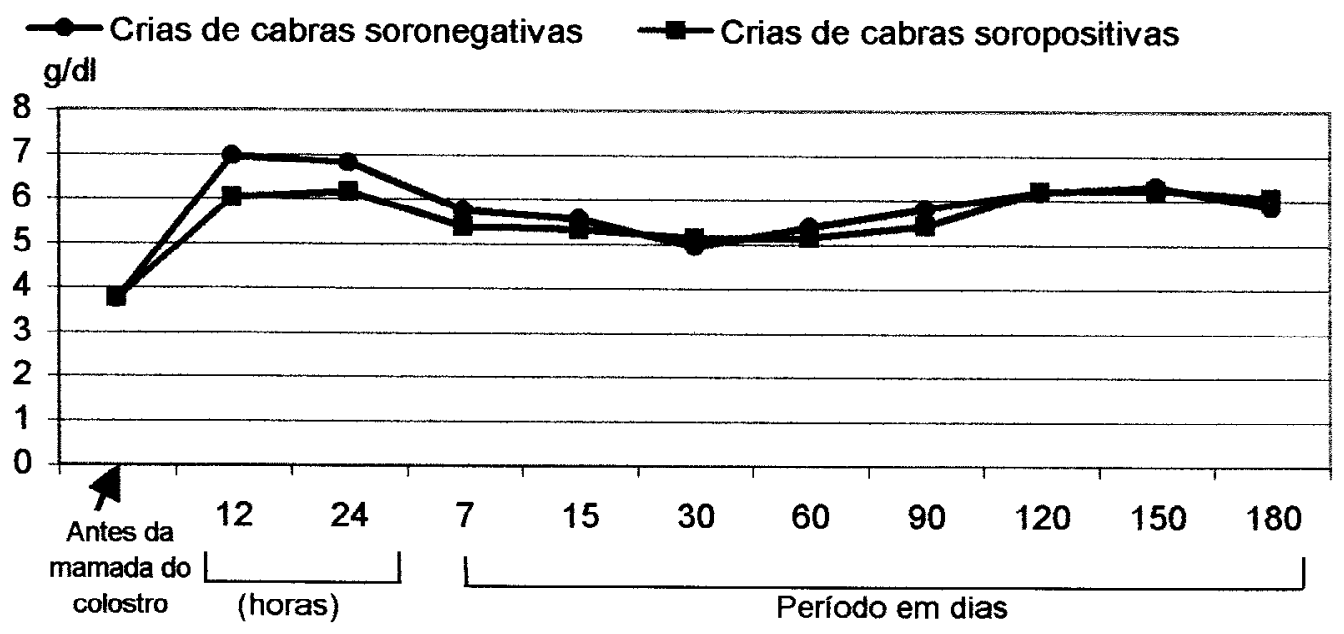

Figura 17 - Variação dos teores de proteína sérica total $(\mathrm{g} / \mathrm{dl})$, determinada no soro sangüíneo de cabritos crias de cabras soronegativas e soropositivas ao vírus da Artrite-encefalite dos Caprinos, do nascimento - antes da ingestão do colostro até 180 dias de vida. São Paulo, 2002. 


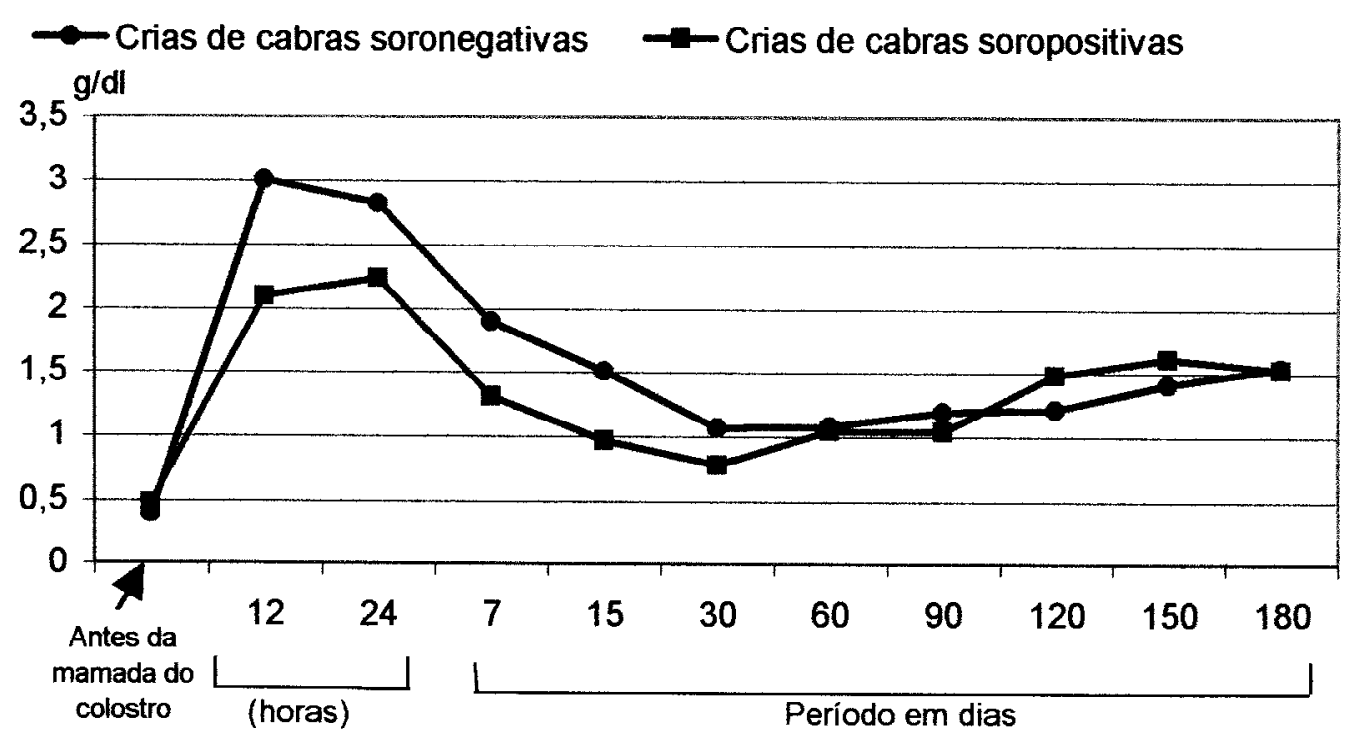

Figura 18 - Variação dos teores de gamaglobulina sérica $(\mathrm{g} / \mathrm{dl})$, determinada no soro sangüíneo de cabritos crias de cabras soronegativas e soropositivas ao vírus da Artrite-encefalite dos Caprinos, do nascimento - antes da ingestão do colostro até 180 dias de vida. São Paulo, 2002.

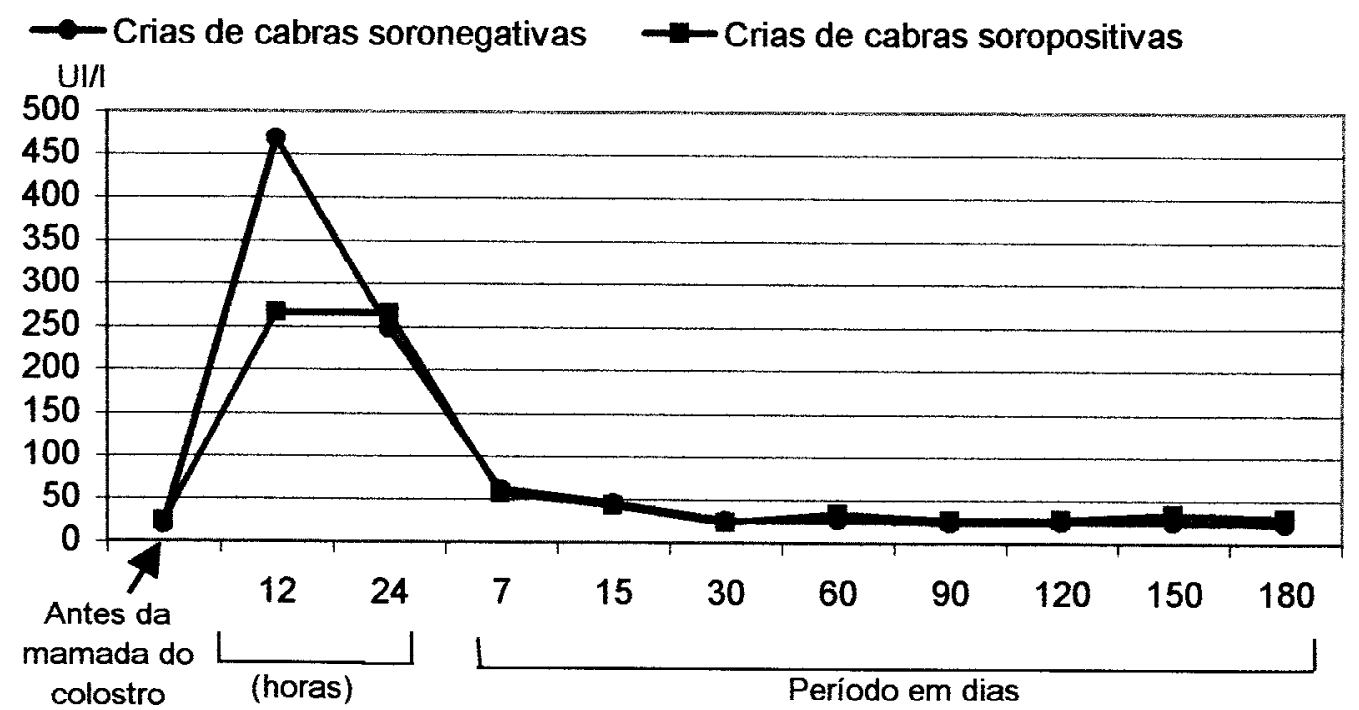

Figura 19 - Variação dos valores da atividade enzimática da gamaglutamiltransferase, expressos em UI/l, determinada no soro sangüíneo de cabritos crias de cabras soronegativas e soropositivas ao vírus da Artrite-encefalite dos Caprinos, do nascimento - antes da ingestão do colostro até 180 dias de vida. São Paulo, 2002. 


\section{DISCUSSÃO}

O delineamento experimental proposto nesta tese permitiu que fosse feita a avaliação da infecção pelo vírus da Artrite-encefalite dos Caprinos em animais criados nos 14 plantéis dos cabris, localizados em 13 municípios no Estado de São Paulo (São Roque, Ibiúna, Vargem Grande Paulista, Piedade, Itapecirica da Serra, Marília, Cotia, Itapetininga, Salesópolis, Arapeí, Pindamonhangaba, Bragança Paulista e Vargem), durante o período de 2 anos, 2000-2001. Inicialmente no estudo clínico-epidemiológico determinou-se que, no mencionado período, a distribuição da freqüência de anticorpos séricos antivírus AEC na amostragem correspondeu a 26,3\% $(861 / 3.280)$.

Ao se comparar o resultado obtido com os apresentados por outros pesquisadores brasileiros, que utilizaram também a imunodifusão em gel de ágar para a detecção de anticorpos antivírus da Artrite-encefalite dos Caprinos, verificou-se que a freqüência média de ocorrência da infecção pelo mencionado agente etiológico viral nos fatos de caprinos avaliados foi equivalente aos valores encontrados e relatados por vários pesquisadores: CUNHA e NASCIMENTO (1995) no Estado do Rio de Janeiro (21,7\%); FERNANDES (1997) no Estado de São Paulo (29,8\%) e RAMALHO (2000) no Estado da Bahia (29,2\%). Por outro lado, discordou-se, por ser maior, dos valores determinados por: MOOJEN et al. (1986) no Rio Grande do Sul, com 16,0\%; ASSIS e GOUVEIA (1994) na Bahia, com 12,8\%; SARAIVA NETO et al. (1995) em Pernambuco, com 17,6\%; PINHEIRO et al. (1996) no Piauí, com 4,4\% e PINHEIRO et al. (2001) no Ceará, com 1,0\%. Ao contrário, o resultado 
desta tese discordou, por ser menor, dos resultados obtidos por alguns pesquisadores brasileiros: FITTERMAN (1988), na Bahia, com taxa de 52,2\%; D’ANGELINO et al.(1993), em São Paulo, com 37,5\%; ASSIS e GOUVEIA (1994), em Minas Gerais, com 33,3\% e MELO e FRANKE (1997), no Ceará, com 40,7\%.

Ao realizar-se a avaliação comparativa do resultado determinado na presente pesquisa, com os apresentados na literatura estrangeira, por diversos estudiosos do assunto, verificou-se que a freqüência da ocorrência da Artrite- encefalite dos Caprinos encontrada em cabris de São Paulo (26,3\%) foi menor do que o determinado: nos Estados Unidos da América (CRAWFORD e ADAMS, 1981; EAST et al., 1987; CUTLIP et al., 1992); na Alemanha (STRAUB, 1983); no Canadá (ADAMS et al., 1984; BÉLANGER e LEBOEUF, 1993); na Noruega (ADAMS et al., 1984); na Suíça (ADAMS et al., 1984; KRIEG e PETERHANS, 1990); na Itália (CAPORALE et al., 1985; AGRIMI et al., 1986); na Hungria (PALFI et al., 1986); na Espanha (GONZÁLES et al., 1987); na França (ADAMS et al., 1984; PERRIN e POLACK, 1987); na Jamaica (GRANT et al., 1993) e na Austrália (GREENWOOD et al., 1995). O valor para a freqüência da ocorrência de anticorpos antivírus da Artrite- encefalite dos Caprinos nos criatórios de caprinos nos 13 municípios paulistas equivaleu-se aos encontrados no México (NAZARA et al., 1985) e na Austrália (GREWAL et al., 1986). Todavia, discordou-se, por ser maior, dos valores referidos no México, no Peru, na África do Sul, no Quênia, na Somália, no Sudão e nas ilhas Fiji (ADAMS et al., 1984); na Nova Zelândia (ADAMS et al., 1984; MacDIARMIND, 1986); na Austrália (SURMAN et al., 1987); na Inglaterra (ADAMS et al., 1984; DAWSON e WILESMITH, 1985); na Alemanha (HEIL, 1986; 
HÄNEL, 1991); na Irlanda do Norte (ADAIR, 1986); na Holanda (HOUWERS, 1987) e na Áustria (SCHÖPF e SCHÖNBAUER, 1990).

A retro-avaliação comparativa demonstrou de forma cabal que os países europeus com maiores taxas de prevalência da Artrite-encefalite dos Caprinos foram aqueles que, em maior número, exportaram caprinos para as várias regiões geoeconômicas do Brasil: França; Suíça; Espanha e Alemanha. Talvez, muitas dessas importações de caprinos de elite por suas peculiaridades raciais e de produtividade foram realizadas em um período mais remoto, quando essa virose não era suficientemente conhecida e diagnosticada. Mas, seguramente, inúmeras das importações de caprinos foram feitas em época que a doença e seus problemas de inibição gradativa da produtividade eram suficientemente conhecidas, e havendo boas possibilidades de diagnósticos nosológico e imunológico, seu controle, seria exeqüível caso a defesa sanitária animal, tivesse sido acionada com eficiência e fosse orientada por técnicos, cientificamente bem preparados. Ressalte-se, que em determinado momento equipes técnicas estrangeiras permaneceram longo período no Brasil, estudando os problemas da Caprinocultura Nacional - tanto no referente à produção, como à saúde animal, e, ao final, de suas missões científicas recomendaram a substituição radical de nossos rebanhos, trocando-os por matrizes e reprodutores de países europeus. Nesta recente fase da caprinocultura brasileira foram introduzidas no sistema criatório as novas raças, com maior potencial genético para melhor produção, para substituírem as raças tradicionais e há muito conhecidas de nossos pecuaristas. E, assim foram introduzidas raças caprinas de elite pela capacidade produtora e reintroduziu-se em nossos rebanhos um novo e maior contingente de animais infectados pelo vírus da Artrite-encefalite dos Caprinos. 
Entre os 14 plantéis de caprinos avaliados no Estado de São Paulo, quatro deles não apresentavam animais com anticorpos séricos antivírus da Artrite- encefalite dos Caprinos, permitindo afirmar-se que 28,6\% (4/14) dos plantéis eram livres da infecção e 71,4\% (10/14) estavam infectados pelo já mencionado vírus. Tal resultado permitiu destacar que a Artrite-encefalite dos Caprinos deveria ser considerada enzoótica no Estado de São Paulo, confirmando os resultados referidos por GARCIA et al. (1992a e 1992b), D’ANGELINO et al. (1993), FERNANDES (1997) e BOHLAND (1998) e reafirmando o que vários pesquisadores detectaram no Brasil (RS - MOOJEN et al., 1986; BA - FITTERMAN, 1988; ASSIS e GOUVEIA, 1994; RAMALHO, 2000; MG - ASSIS e GOUVEIA, 1994; RJ - CUNHA e NASCIMENTO, 1995; PE - SARAIVA NETO et al., 1995; PI PINHEIRO et al., 1996; CE - MELO e FRANKE, 1997; PINHEIRO et al., 2001). Além do mais, as inúmeras pesquisas estrangeiras, embasadas nas afirmações pioneiras de CRAWFORD e ADAMS (1981), que demonstraram a ocorrência da Artrite- encefalite dos Caprinos em 24 regiões dos Estados Unidos, para a seguir ADAMS et al. (1984) demonstrarem essa virose em 14 países localizados nos cinco continentes levando-os a considerarem o vírus da AEC originário do continente europeu, associadas às considerações apresentadas por STRAUB (1983), CAPORALE et al. (1985), DAWSON e WILESMITH (1985), NAZARA et al. (1985), AGRIMI et al. (1986), HEIL (1986), GREWAL et al. (1986), MACDIARMIND (1986), PALFI et al. (1986), ADAIR (1986), EAST (1987), GONZALES et al. (1987), HOUWERS PERIN e POLACK (1987), SURMAN et al. (1987), SCHÖPF e SCHÖNBAUER (1990), KRIEG e PETERHANS (1990), HÄNEL (1991), CUTLIP et al. (1992), BÉLANGER e LEBOEF (1993), GRANT et al. (1993) e 
GREENWOOD et al. (1995) que, seguramente induziram à Oficina Internacional de Epizootias, (OIE, 2000) considerar a Artrite-encefalite dos Caprinos uma doença viral multissistêmica específica dos caprinos e cosmopolita. Os resultados, dos já mencionados pesquisadores brasileiros e os apresentados nesta tese, confirmaram e reafirmaram a Artrite-encefalite dos Caprinos como uma doença cosmopolita e além disso enzoótica em várias regiões geoeconômicas brasileiras - onde a criação de caprinos apresenta significativo valor econômico, inclusive no Estado de São Paulo.

Ao analisarem-se os resultados obtidos nas amostras de soro sangüíneo colhidas nos plantéis dos 14 cabris, considerando-se a freqüência da ocorrência de anticorpos antivírus da Artriteencefalite dos Caprinos nos quatro momentos de colheita de amostras, no período de dois anos 2000-2001, puderam ser observadas significativas variações. Essas variações em alguns plantéis de caprinos puderam ser atribuídas ao efeito e aplicação das recomendações feitas aos criadores para controle da infecção. Assim sendo, em quatro plantéis livres da Artrite- encefalite dos Caprinos (cabris 1, 2, 3 e 4) observou-se que as recomendações, quando aceitas e aplicadas permitiriam, como permitiram a manutenção dos plantéis livres da infecção. Nas mesmas circunstâncias houve possibilidade de controlar-se a taxa de prevalência da infecção em outros quatro plantéis $(6,8,9$ e 14), nesses, respectivamente, detectou-se freqüências variando da seguinte maneira: cabril $n^{\circ} 6-7,8 \%$ (5/64), 7,1\% (4/56), 3,3 (2/61) e 2,5\% (2/79); cabril no 8 - 18,1\% (17/94), 19,8\% (17/86), 11,4\% $(9 / 79)$ e $11,3 \%(8 / 71)$; cabril $n^{\circ} 9-20,0 \%(4 / 20), 0 \%(0 / 16), 0 \%(0 / 20)$ e $0 \%(0 / 15)$; cabril $\mathrm{n}^{\circ} 14-80,6 \%(25 / 31), 64,0 \%(16 / 25), 48,3 \%(14 / 29)$ e $41,9 \% \quad(13 / 31)$. Nos cabris $\mathrm{n}^{\circ} 6$ e 8 haveria, em futuro próximo, boas possibilidades para conseguir-se a erradicação 
da Artrite-encefalite dos Caprinos. Em quatro cabris (5, 7, 11 e 12), avaliados nesta tese, observou-se, no período de dois anos aumento da freqüência da ocorrência de anticorpos séricos antivírus AEC, as freqüências obtidas no período 2000-2001 foram as seguintes: cabril $\mathrm{n}^{\circ} 5-2,6 \%(1 / 39), 11,1 \%$ (5/45), 7,3\% (4/55) e 10,8\% (8/74); cabril n 7 - 10,7\% (3/28), 11,6\% (5/43), 12,2\%(5/41) e 26,2\% (11/42); cabril $n^{\circ} 11-32,1 \%$ (17/53), 40,5\% (45/111), 46,8\% (58/124) e 56,0\% (51/91); cabril n ${ }^{\circ} 12$ $-56,3 \%$ (40/71), 75,6\% (62/82), 63,5\% (47/74) e 78,9\% (30/38).

A literatura compulsada, não apresentou, quer seja na pesquisa nacional ou na estrangeira qualquer estudo que analisasse a incidência e/ou evolução da freqüência de animais infectados pelo vírus da Artrite-encefalite em fatos de caprinos durante um período pré-determinado de tempo, e por isso não houve possibilidade de uma análise comparativa. Todavia os resultados obtidos deixaram claro a existência de plena possibilidade, ao se usar um sistema adequado de profilaxia, fazer-se o controle sanitário dos plantéis e impedir a ocorrência da infecção em rebanhos livres da doença. Da mesma forma, a obediência das normas de profilaxia da enfermidade, permitiu o controle da infecção em vários plantéis de caprinos, conseguindo em um deles erradicar a Artriteencefalite dos Caprinos. Nos rebanhos de caprinos, nos quais observou-se aumento da freqüência de animais infectados pelo vírus da Artrite-encefalite dos Caprinos, o incremento pôde ser atribuído a substituição dos efetivos do plantel, por descarte não planejado e orientado de forma adequada (eliminação dos caprinos sororeagentes positivos) e introdução de caprinos sadios - não possuidores de anticorpos séricos antivírus AEC nos plantéis, após quarentena de no mínimo 90-120 dias. Além do mais, no manejo sanitário do criatório deveriam ser evitadas todas as formas de transmissão horizontal 
da virose, tais como de aleitamento dos cabritos, e tratamentos clínicos cruentos, injeções, vacinações e principalmente tatuagens com equipamentos não esterilizados ou descartáveis. Ressalte-se que muitas dessas recomendações para controle da Artrite-encefalite dos Caprinos concordaram com aquelas apresentadas por GREENWOOD et al. (1986) e VON MOCKENHAUPT e BAUER (1987)

Nos plantéis dos 14 cabris estudados no Estado de São Paulo eram criados sete grupos raciais de caprinos produtores de leite, das quais foram colhidas, nos quatro momentos estipulados para o período 2000-2001, 3.280 amostras de sangue, para obtenção de soro sangüíneo e determinação da freqüência de anticorpos antivírus da Artrite-encefalite dos Caprinos. Ao se considerar a multiplicidade de raças de caprinos criadas nos plantéis avaliados era lógico que o número de amostras colhidas por raça não fosse homogeneamente equilibrado. As 3.280 amostras foram assim distribuídas: caprinos da raça Saanen 2.458 amostras examinadas ou seja $74,9 \%$, das quais 673 eram sororeagentes positivas $(27,4 \%)$; caprinos da raça Alpina, com $497(15,2 \%)$ amostras examinadas, das quais 59 (11,9\%) eram sororeagentes positivas; caprinos da raça Anglo Nubiana dos quais colheram-se 138 (4,2\%) amostras, sendo $88(63,8 \%)$ sororeagentes positivas; caprinos mestiços dos quais colheram-se $103(3,1 \%)$ amostras, sendo $11(10,7 \%)$ sororeagentes positivas; caprinos da raça Toggenbourg, dos quais colheram-se 50 (1,5\%) amostras de sangue, sendo $28(56,0 \%)$ sororeagentes positivas e animais da raça Bôer, com 34 (1,0\%) amostras de sangue colhidas, sendo duas sororeagentes positivas (5,9\%).

A análise estatística demonstrou que apenas quatro dos 15 contrastes possíveis não demonstraram diferenças estatisticamente significativas, entre a freqüência de animais infectados pelo vírus da Artrite-encefalite dos Caprinos. Esses 
contrastes foram os seguintes: raça Alpina X raça Bôer (11,9\% X 5,9\%); raça Bôer X caprinos mestiços (5,9\% X 10,7\%); raça Alpina X animais mestiços (11,9\% X 10,7\%) e animais da raça Anglo Nubiana X caprinos da raça Toggenbourg (63,8\% X 56,0\%).

Os resultados obtidos permitiram afirmar que fatores de variabilidade relacionado às condições raciais dos caprinos influíram de forma significativa sobre as taxas de freqüência de ocorrência de infecção dos animais pelo vírus da Artrite-encefalite dos Caprinos. Estes resultados concordaram com a maioria das observações relatadas por pesquisadores brasileiros como: por FERNANDES (1997), que trabalhando com caprinos das raças Saanen, Alpina, Toggenbourg, Anglo Nubiana e animais mestiços, verificaram maior taxa de prevalência de caprinos sororeagentes aos antígenos do vírus da Artrite- encefalite dos Caprinos, entre os animais da raça Anglo Nubiana; com a afirmação de SARAIVA NETO et al. (1995), ao destacar que, em caprinos de raças européias o número de sororeagentes positivos era maior do que o obtido em animais mestiços ou de origem africana (raças Mambrina e Anglo Nubiana); e por RAMALHO (2000), que em caprinos das raças leiteiras Alpina e Saanen demonstrou taxa de prevalência maior, do que em outras raças submetidas à criação extensiva - Anglo Nubiana, Mambrina e caprinos mestiços. Os presentes resultados, todavia discordaram daqueles apresentados por BOHLAND (1998), por não demonstrarem diferenças significativas entre as taxas de prevalência da infecção pelo vírus da Artrite-encefalite dos Caprinos em animais das raças leiteiras Saanen e Alpina, criadas em São Paulo.

Os resultados da freqüência de ocorrência de caprinos sororeagentes positivos aos antígenos do vírus da Artrite-encefalite dos Caprinos, pertencente a várias raças leiteiras criadas no Estado de São Paulo concordaram de modo geral com 
afirmações relatadas na literatura estrangeira da especialidade. Assim sendo, concordou-se com NAZARA et al. (1985), que não encontraram resultados soropositivos em amostras de soro sangüíneo de caprinos nativos criados para produção de de carne, mas em contraposição detectaram inúmeras amostras soropositivas, colhidas de caprinos de raças leiteiras (Anglo Nubiana, Toggenbourg, Saanen e Aplina) importados, principalmente dos Estados Unidos da América e da Europa. Do mesmo modo, concordou-se com as conclusões de GREWAL et al. (1986), que demonstraram maior freqüência da infecção em caprinos de raça leiteira (Nubiana, Toggenbourg, Saanen, Alpina Inglesa e seus mestiços) do que em raças de caprinos especializadas para a produção de fibras (Angorá e Cashmere).

Os valores encontrados neste trabalho discordaram dos verificados por CRAWFORD e ADAMS (1981), que estudando caprinos de diferentes raças (Alpina, Angorá, La Mancha, Nubiana, Pygmy, Saanen, Toggenbourg e seus mestiços) não encontraram diferenças estatisticamente significativas, entre as freqüências de ocorrência da infecção pelo vírus da Artrite-encefalite dos Caprinos. Discordou-se também da afirmação de EAST et al. (1987), que confirmaram as conclusões relatadas por CRAWFORD e ADAMS (1981).

Ao se fazer a proposição para estudar a variabilidade de taxas de prevalência ou estabelecer a freqüência da ocorrência de uma infecção sob a influência de fatores raciais dois aspectos, primordiais devem ser considerados: os referentes a fatores primários, relacionados diretamente ao patrimônio genético de cada uma das raças avaliadas e; em segunda posição devem ser considerados os fatores secundários ou indiretos, relacionados às condições particulares de criação, manejo, alojamento e alimentação exigidas por espécimes destas raças, para que atinjam o desejado 
desempenho de produção. As considerações anteriormente detalhadas explicariam e justificariam a discrepância dos resultados referidos na literatura e especializada e considerada nesta item.

Pelas razões apresentadas tornou-se necessária a afirmação categórica que as diferenças das freqüências de caprinos sororeagentes positivos aos antígenos de vírus da AEC observadas entre as várias raças criadas em São Paulo estariam diretamente relacionadas ao sistema de criação e tipo de produção de destino do gado cabrum, bem como às medidas profiláticas de controle da Artriteencefalite dos Caprinos adotadas para o plantel do cabril. Todavia, os resultados apresentados nesta tese, destacando maiores freqüências de caprinos sororeagentes ao vírus AEC das raças Anglo Nubiana (63,8\%) e Toggenbourg (56,0\%), significativamente, maiores do que semelhantes valores determinados nos animais das raças Saanen (27,4\%) e Alpina (11,9\%) se prestaram para reforçar a opinião de alguns pesquisadores, que afirmaram a origem européia do vírus da Artrite-encefalite dos Caprinos, atingindo o continente americano por importações mal orientadas e adaptações inadequadas às novas condições ambientais. Além do mais, permitiram supor-se que, no caso do Brasil e, particularmente, do Estado de São Paulo, a introdução do vírus deu-se em duas fases: a primeira pela importação de raças mais tradicionais em nossa pecuária de caprinos - a Toggenbourg e a Anglo Nubiana; a segunda pela mais recente importação das raças Saanen, Alpina e outras raças caprinas européias, especializadas para a produção de leite.

A avaliação da população de caprinos estudada, não demonstrou existência de diferenças signifivativas entre o número de animais sororeagentes ao 
vírus da Artrite-encefalite dos Caprinos, que pudessem ser atribuídas à influência de fatores de variabilidade relacionadas ao sexo, mesmo ao se considerarem apenas os caprinos púberes. Os resultados foram os seguintes: para os bodes de $32,3 \%(94 / 291)$ e para cabras de $27,9 \%(663 / 2.375)$. Essa observação concordou com as apresentadas por EAST et al. (1987), CUTLIP et al. (1992), SARAIVA NETO et al. (1995), FERNANDES (1997), MELO e FRANKE (1997) e RAMALHO (2000). Entretanto o resultado obtido nesta tese discordou dos referidos nas pesquisas realizadas por CRAWFORD e ADAMS (1981), GREWAL et al. (1986) e BOLHAND (1998).

Alguns pesquisadores relataram que a maior taxa de prevalência estimada, em algumas circunstâncias para determinado grupo sexual, não estaria primaria e diretamente relacionada aos fatores sexuais ou a suposta maior ou menor susceptibilidade de um dos sexos. As diferenças, freqüentemente descritas, estariam relacionadas a certas normas de manejo dos caprinos, às vezes privilegiando os machos e, em outras, as fêmeas (CRAWFORD e ADAMS, 1981; GREWAL et al., 1986). Os resultados obtidos na presente pesquisa permitiram supor-se que na dependência do manejo dos bodes e cabras num plantel, ele poderia influir na freqüência da ocorrência da infecção pelo vírus da Artrite-encefalite dos Caprinos: principalmente pela convivência de machos e fêmeas, no mesmo ambiente (criações extensivas ou semi-extensiva) e ao manejo sanitário, principalmente pela aplicação de tecnologias mal orientadas, facilitando a transmissão iatrogênica do agente etiológico. Ressalte-se que na maioria dos plantéis dos 14 cabris avaliados nesta pesquisa o manejo dos machos e fêmeas era assemelhado, podendo ser considerados em, inúmeras circunstâncias equivalentes. 
Entre os objetivos propostos no delineamento desta pesquisa sobre características clínicas e epidemiológicas da Artrite-encefalite dos Caprinos, mereceu destaque a intenção de avaliar as variações das freqüências de ocorrência de anticorpos séricos antivírus AEC durante o desenvolvimento etário dos caprinos criados e mantidos nos 14 cabris do Estado de São Paulo. Os resultados obtidos demonstraram de forma categórica a influência dos fatores etários sobre a variabilidade da freqüência de anticorpos séricos antivírus da Artrite-encefalite dos Caprinos. A análise dos resultados tabulados ou apresentados em figuras permitiu afirmar-se aumento gradativo e estatisticamente significativo diretamente proporcional ao desenvolvimento etário, sendo a freqüência de ocorrência de anticorpos antivírus AEC significativamente maiores nos animais mais velhos. Em resumo os resultados demonstraram a seguinte variação, de anticorpos séricos antivírus AEC, considerados os sete grupos etários: cabritos com até 6 meses de idade - 18,4\% (89/485); cabritos cujas idades variavam entre 6 e 12 meses - 15,2\% (73/481); caprinos jovens com idades variando de 12 e 24 meses - 21,0\% (164/782); no grupo de animais adultos composto por caprinos cuja idade oscilava entre 24 e 36 meses - 27,9\% (157/562); caprinos adultos com idades entre 36 e 48 meses $34,8 \%$ (131/376); caprinos com idades variando de 48 a 60 meses - 32,7\% (84/257) e nos caprinos com mais de 60 meses de idade - 48,4\% (163/337). Esses resultados confirmaram as observações apresentadas por SARAIVA NETO et al. (1995), em Pernambuco; FERNANDES (1997) e BOHLAND (1998), em São Paulo e RAMALHO (2000), na Bahia. Eles, também concordaram com os resultados inseridos na literatura estrangeira e referidos por EAST et al. (1987), PERRIN e POLACK (1987) e CUTLIP et al. (1992). Outros autores, como GREWAL et al. 
(1986) e MELO e FRANKE (1997), não verificaram a influência da idade sobre a doença, ou sobre a prevalência de anticorpos antivírus AEC e por isso os resultados observados nesta tese deles discordaram.

Da mesma forma discordou-se das observações de DAWSON e WILESMITH (1985) que afirmaram ser maior a freqüência de anticorpos antivírus da Artrite-encefalite dos Caprinos nas amostras de soro sangüíneo de caprinos de um ano de idade, do que aquela determinada no soro sangüíneo de animais com dois anos de idade. Afora as pesquisas apresentadas por pesquisadores brasileiros (SARAIVA NETO et al., 1995; FERNANDES, 1997 e BOHLAND, 1998 e RAMALHO, 2000) não houve o devido aprofundamento no estudo da influência do desenvolvimento etário sobre a infecção de caprinos pelo vírus da Artrite-encefalite dos Caprinos, pois não foi um fator de estudo constante na literatura, estratificar-se a população examinada em vários grupos etários, como foi a opção do delineamento experimental desta tese. Apesar de tudo, pôde-se constatar nas citações da literatura existirem diferenças significativas entre a freqüência de infecções em grupos de animais jovens, adultos e velhos.

Os resultados obtidos nesta tese permitiram afirmar, com segurança, que as diferenças não se relacionavam com maior ou menor susceptibilidade dos caprinos jovens, adultos ou velhos ao potencial de patogenicidade do vírus; mas que essas variações estariam relacionadas a uma particularidade biológica do vírus causador da Artrite-encefalite dos Caprinos. Aliás carcaterística de todos os vírus da família Retroviridae: uma vez infectado o caprino, ele permaneceria infectado por toda a vida, mantendo sempre a capacidade de infectar os companheiros do plantel ou seus descendentes. (NARAYAN et al., 1980; NARAYAN et al., 1982; NARAYAN 
et al., 1983; KENNEDY-STOSKOPF et al., 1985; NARAYAN e CORK, 1990; COFFIN, 1996; JOAG et al., 1996; FRANCKI et al., 1991; EAST, 1996).

Assim sendo, baseado nos resultados desta pesquisa e nos inúmeros conhecimentos do ciclo biológico do vírus da Artrite-encefalite dos Caprinos, como relatado pelos pesquisadores referidos na revisão bibliográfica, pôde afirmar-se com convicção que a incidência cumulativa da infecção seria responsável pelo aumento gradativo e significativo da freqüência de caprinos infectados pelo vírus da $\mathrm{AEC}$, diretamente proporcional com o desenvolvimento etário. Pois não sendo grande a mortalidade da doença e sua evolução freqüentemente assintomática ou crônica, a permanência de caprinos longos anos no plantel, se associariam nos vários grupos etários e aos antigos animais se juntariam os caprinos recém infectados nas faixas etárias. Em suma, o maior tempo de permanência de um caprino em um plantel infectado pelo vírus AEC, aumentaria, com o passar do tempo as chances dele se infectar.

Outro detalhe que deve ser mencionado na análise crítica dos resultados obtidos em caprinos de várias faixas etárias foram os valores das freqüências de caprinos dos grupos experimentais formados por animais com até 6 meses de idade e aquele com cabritos com idades variando entre 6 e 12 meses e que foram, respectivamente: 18,4\% (89/485) e 15,2\% (73/481). Aparente e paradoxalmente, poder-se-ía imaginar que esses resultados se contrapusessem às afirmações anteriormente explanadas - a freqüência deveria aumentar com o evoluir da idade ! Esta diminuição da freqüência da ocorrência de anticorpos séricos antivírus da Artrite-encefalite dos Caprinos evidente, na segunda faixa etária, se explicou pelo consumo ou esgotamento dos anticorpos (imunoglobulinas), que tivessem sido 
passivamente transferidos aos cabritos pela ingestão do colostro. Pois entre cabritos do primeiro grupo, composto por animais com até 6 meses de idade, existiam inúmeros animais com menos de 120 dias de idade, crias de cabras sororeagentes positivas, que aleitaram seus filhotes, transferindo-lhes anticorpos antivírus da Artrite-encefalite dos Caprinos. Esse fato será mais discutido, oportunamente, e foi ressaltado por vários pesquisadores referidos na revisão de literatura sobre o assunto (ADAMS et al., 1983; ELLIS et al., 1986; BULGIN, 1990).

O conhecimento prévio dos questionamentos encontrados na bibliografia específica compulsada, relacionados a potencialidade da influência do sistema de manejo de criação sobre a maior ou menor disseminação da infecção pelo vírus da Artrite-encefalite dos Caprinos, quer seja entre efetivos de um plantel onde a enfermidade foi considerada enzoótica, como também para espécimes de fatos de caprinos livres dessa infecção, já no delineamento experimental, defrontou-se com a necessidade de comparar-se a freqüência da ocorrência da mencionada virose em caprinos submetidos a sistemas intensivo e semi -extensivo de criação, de acordo com as normas da pecuária de gado cabrum paulista.

A avaliação dos resultados obtidos nos dois grupos experimentais para avaliação da freqüência de caprinos com Artrite-encefalite desses animais: um formado por 2.303 animais submetidos a regime intensivo de criação, perfazendo $70,2 \%$ da amostragem avaliada e; outro constituído por 977 caprinos em regime semi-extensivo de criação, participando em proporção de 29,8\% na amostragem utilizada nesta tese. A comparação dos resultados obtidos demonstrou diferença estatisticamente significativa entre os valores de freqüência de caprinos sororeagentes 
positivos aos antígenos do vírus da Artrite-encefalite dos Caprinos nos dois agrupamentos de caprinos. Pois 31,8\% (733/2.303) dos caprinos submetidos às normas do sistema intensivo de criação estavam infectados pelo mencionado vírus, contra apenas 13,1\% (128/977) dos caprinos em regime semiextensivo de criação. Demonstrou-se, desta forma que as normas aplicadas nos sistemas de criação de caprinos no Estado de São Paulo representavam significativos fatores de variabilidade nos índices de infecção e de disseminação da infecção pelo já mencionado vírus.

$\mathrm{Na}$ década de 80, primórdio das pesquisas dirigidas para a elucidação da Artriteencefalite dos Caprinos, CRAWFORD e ADAMS (1981) e GREWAL et al. (1986) afirmaram que as diferentes taxas de prevalência da infecção dos caprinos, machos, nas fêmeas ou nas várias raças estudadas seriam influenciadas por vários fatores não relacionados a fatores intrinsicos, sendo seguramente dependentes de sistema de criação ao qual eram submetidos os animais. Os resultados da presente pesquisa confirmaram essas afirmações, de forma categórica e objetiva.

Posteriormente, ADAMS et al. (1984), relataram que o maiores indices de freqüência da Artrite-encefalite dos Caprinos ocorria em animais mantidos em sistema intensivo de criação, para produção leiteira, podendo essa maior incidência da infecção estar relacionada ao tipo de tecnologia empregada nesse tipo de criação, que na pecuária moderna recomendaria métodos sofisticados e considerados zootecnicamente adequados à maior produtividade do animal. Entretanto, se a aplicação dessa tecnologia sofisticada não respeitassem de forma adequada as normas fundamentais da Clínica Veterinária, para preservação, manutenção e recuperação da saúde dos animais, não se conseguiria controlar ou erradicar a ocorrência desta virose, e manter adequada produção do plantel, pois segundo BIRGEL (1997) "não 
há produção animal, com boa produtividade, sem a preservação e recuperação da saúde dos efetivos dos rebanhos". E, como pôde ser comprovado pelos resultados obtidos nesta tese, sem a obediência desse axioma a Artrite- encefalite dos Caprinos não poderia, jamais ser controlada ou erradicada dos plantéis.

No estudo da epidemiologia da Artrite-encefalite dos Caprinos houve grande preocupação em estabelecer as razões que pudessem explicar a disseminação da infecção nos rebanhos e, procurou-se determinar a susceptibilidade dos caprinos ao vírus. Assim, NAZARA et al. (1985), verificaram que rebanhos de caprinos "Criollos" criados no México não apresentavam anticorpos antivírus da $\mathrm{AEC}$, contudo em raças leiteiras das mesmas regiões a prevalência de animais sororeagentes positivos era substancialmente maior, ou seja, de 27,1\%. Tal diferença não foi atribuída, pelos referidos pesquisadores, à influência dos diferentes sistemas de criação a que os caprinos se submetiam: um intensivo com animais confinados em promiscuo e íntimo contato corpóreo e, outro extensivo, com os caprinos libertos em campos amplos, dificultando o permanente e íntimo contato corpóreo. Assim sendo, atribuiu-se, erroneamente, as diferenças observadas a uma suposta resistência dos caprinos primitivos, da raça "Criolla" ao vírus causador da Artrite-encefalite dos Caprinos. Essas afirmações viriam a ser confirmadas um ano depois, por GREWAL et al. (1986), na Austrália, reafirmando o erro conceitual primário. Pois esses autores detectaram maior freqüência da ocorrência da Artrite-encefalite dos Caprinos em animais produtores de leite das raças Alpina Inglesa, Nubiana, Saanen e Toggenbourg, do que a observada em caprinos nativos de raças especializadas na produção de fibras - Angorá e Cashemere. Criou-se, deste modo, um mito que se 
manteve em várias regiões do mundo, acreditando-se que algumas raças primitivas de animais domésticos poderiam se resistentes a alguns agentes infecciosos.

Para satisfação da Ciência Veterinária Brasileira, pesquisas realizadas em nosso país, obedecendo a critérios mais rígidos, estabelecidos pelos ditames do exercício da moderna Clínica Veterinária, apesar de muitas dificuldades tecnológicas e de apoio Institucional, foram, gradativamente elucidando as dúvidas, aclarando-as, culminando com os resultados ora apresentados e que talvez sejam alicerces de um futuro promissor para maiores realizações da caprinocultura Paulista e controle da Artrite-encefalite dos Caprinos no Brasil. Assim pôde-se afirmar, que a suposta resistência de alguns tipos de caprinos à Artriteencefalite dos Caprinos não correspondia à realidade, conceito errôneo que já fora contestado por MELO e FRANKE (1997), que relataram uma maior freqüência da ocorrência de provas soropositivas aos antígenos do vírus da Artrite-encefalite em caprinos criados em sistema intensivo de manejo. Os autores sugeriram que essa maior prevalência poderia ser explicada pelo estreito contato dos animais confinados e pela amamentação coletiva dos cabritos assim aleitados. Por outro lado, RAMALHO (2000), trabalhando com animais submetidos aos sistemas de criação intensivo, extensivo e semi-extensivo, verificou que os animais criados em regime semi- extensivo apresentavam uma maior prevalência de resultados sororeagentes aos antígenos do vírus AEC do que os criados em regime intensivo. Mas destacou a pesquisadora a particularidade dessas criações intensivas, em pequenas propriedades mantendo poucos animais para produção de leite. Esses caprinos, eram criados em cabris supervisionados por Clínicos Veterinários, preparados para o atendimento de caprinos e aos produtores eram feitas recomendações para o controle da Artrite- encefalite dos 
Caprinos, sendo essas medidas atendidas e seguidas à risca pelos caprinocultores. No grupo de caprinos criados em sistema extensivo, com pequena lotação das áreas de criação, não permitindo o íntimo contato corpóreo entre animais companheiros de rebanho, a freqüência de caprinos infectados pelo vírus AEC, também foi muito pequena.

A análise crítica e comparativa dos resultados obtidos na presente pesquisa e os relacionados ao tema referidos na bibliografia compulsada, permitiu que se afirmasse: a freqüência da ocorrência da infecção de caprinos de um plantel pelo vírus causador da Artrite-encefalite dos Caprinos foi, fortemente, influenciada por fatores dependentes do sistema de criação e do manejo dos rebanhos. A criação extensiva dificulta a disseminação da Artrite-encefalite dos Caprinos por impedir o constante e íntimo contato dos indivíduos do plantel, reduzindo a possibilidade da transmissão horizontal do vírus. Ao contrário nas criações semi-extensivas e intensivas, pelo confinamento e maior manejo dos rebanhos facilitariam a transmissão horizontal e iatrogênica do vírus. Mas caberia aceitar e destacar neste momento a afirmação de RAMALHO (2000), enaltecendo a tecnologia de criação de caprinos, quando bem aplicada e utilizada, como também as recomendações clínico- epidemiológicas para o controle da Artrite-encefalite dos Caprinos nos rebanhos, devendo estas serem: pertinentes e feitas por clínico experiente e cientificamente formado para esse exercício profissional, além disso é óbvio destacar-se: que as recomendações profiláticas sejam bem acatadas e melhor aplicadas.

Segundo a literatura compulsada a Artrite-encefalite dos Caprinos foi descrita por AL-ANI e VESTWEBER (1984) como uma doença multissistêmica, pois 
poderia comprometer vários órgãos do enfermo, no ciclo de sua evolução. E, a doença foi caracterizada por apresentar quatro possíveis formas clínicas: articular; nervosa; mamária e pulmonar (CORK et al., 1974; CRAWFORD et al., 1980; SIMS et al., 1983; AGRIMI et al., 1986; LERONDELLE et al., 1989; GEORGE, 1996). A forma clínica articular, descrita em caprinos com mais de 6 meses de idade por EAST (1996), mas conhecida na Suíça, desde 1964 (STÜNZI et al., 1964), sendo mais freqüente sua ocorrência em animais adultos NARAYAN e CORK, 1990). A forma nervosa, acometendo principalmente cabritos, entre 2 e 4 meses de idade foi caracterizada por CORK et al. (1974) e CORK (1976), sendo considerada rara em animais adultos (CRAWFORD e ADAMS, 1981). A forma clínica mamária da enfermidade causada pelo vírus da Artrite-encefalite dos Caprinos, determinaria um endurecimento progressivo da glândula mamária, sendo por isso chamada de mamite endurativa, com diminuição da produção láctea, que poderia até chegar a agalaxia (KENNEDYSTOSKOPF et al., 1985; SMITH e CUTLIP, 1988; LERONDELLE et al., 1989; KRIEG e PETERHANS, 1990; PÉTURSSON et al., 1992; GREENWOOD, 1995; EAST, 1996; BOHLAND, 1998). A forma pulmonar da Artrite-encefalite dos Caprinos, freqüentemente estava associada à forma nervosa como relataram CORK et al. (1974), CORK (1976), SUNDQUIST et al. (1981) e ELLIS et al. (1988), assemelhando-se à Pneumonia Progressiva d os Ovinos causada pelo vírus Maedi- visna (PÉTURSSON et al., 1992). Na evolução da formas clínicas da Artrite-encefalite dos Caprinos o animal doente apresentaria comprometimento do estado geral, caracterizado por emagrecimento acentuado (CRAWFORD e ADAMS, 1981). Paralelamente ao estudo do quadro clínico, vários pesquisadores dedicaram-se a descrição das lesões da Artrite-encefalite dos Caprinos e caracterização dos quadros 
anatomopatológicos (CORK et al., 1974; CORK, 1976; ADAMS et al., 1980; CRAWFORD et al., 1980; CRAWFORD e ADAMS, 1981; SIMS et al., 1983; ELLIS et al., 1988; NARAYAN e CORK, 1990; PÉTURSSON et al., 1992).

Apesar de ter-se, neste preâmbulo, feito a caracterização indubitável da Artriteencefalite dos Caprinos como o de uma enfermidade multissistêmica, no delineamento experimental proposto para esta tese objetivou-se apenas quantificarem-se as manifestações clínicas relacionadas às alterações articulares e mamárias, ocorrências freqüentes na evolução dos casos clínicos dessa enfermidade.

A partir da evidenciação da Artrite-encefalite nos animais da espécie caprina, nos anos 70, idealizaram-se e recomendaram-se várias normas semiológicas de diagnóstico, baseadas no quadro sintomático (CORK, 1976; CRAWFORD e ADAMS, 1981). Alguns pesquisadores deram destaque ao Índice Clínico Articular, que seria um indicativo seguro para o diagnóstico nosológico da artrite que ocorria de forma predominante nesta enfermidade (STÜNZI et al., 1964; MONICAT, 1987; PERRIN et al., 1988), apesar de, no Brasil, alguns especialistas contestarem essa possibilidade (GARCIA et al., 1992b; ROSSINI et al., 1996). Entretanto, a proposta para o diagnóstico definitivo da doença já fora formulada, em 1980, por CRAWFORD et al. (1980) determinado que o diagnóstico clínico deveria ser apenas estabelecido, quando as manifestações sintomáticas fossem confirmadas por um teste imunosorológico positivo; para isso recomendou-se a utilização da imunodifusão em gel de ágar, usando antígenos do vírus da Artrite-encefalite dos Caprinos ou do Maedi-visna (CRAWFORD e ADAMS, 1981; ELLIS et al., 1988; OIE, 2000) ou o teste imunoenzimático (OIE, 2000). Todavia a constatação da infecção pelo vírus da AEC poderia ser feita por outros meios de exame clínico, a saber: por métodos 
diretos de evidenciação do vírus ou por técnicas indiretas detectando a formação de anticorpos plasmáticos antivírus AEC.

Entre os métodos diretos destacaram-se os seguintes: detecção direta da presença do vírus no organismo do caprino, podendo ser realizada, pelo isolamento do agente etiológico, em cultura celular (CRAWFORD et al., 1980; OLIVER et al., 1982; RUSSO, 1983; SIMS et al., 1983; HÖTZEL et al., 1993; TEST et al., 1999; CASTRO et al., 1999b); por evidenciação do vírus em microscopia eletrônica (ELLIS et al., 1983); pela reação em cadeia de polimerase - PCR (RIMSTAD et al., 1993; CLAVIJO e THORSEN, 1996) ou pela hibridização in situ (ZINK et al., 1990).

Entre as técnicas de determinação indireta da infecção, puderam ser destacadas as seguintes: detecção de anticorpos séricos específicos por técnicas soro- imunológicas como imunodifusão em gel de ágar (CUTLIP et al., 1977; CRAWFORD e ADAMS, 1981; ADAMS et al., 1985); ensaio imunoenzimático - ELISA (ELLIS et al., 1983; ARCHAMBAULT et al., 1988; ZANONI et al., 1989; HÄNEL, 1991; HECKERT et al., 1992; RIMSTAD et al., 1994; CASTRO et al., 1999a; SAMAN et al., 1999); imunofluorescência indireta (REISCHAK, 2000) e Western Blot(ZANONI et al., 1989; RIMSTAD et al., 1993). Devido a praticidade de colheita das amostras de soro sangüíneo e ao custo reduzido para a realização das mencionadas provas, os métodos sorológicos foram amplamente recomendados e utilizados para auxiliar o diagnóstico da infecção pelo vírus da Artrite-encefalite dos Caprinos (KNOWLES, 1997).

Alguns autores afirmaram serem variáveis as percentagens de caprinos infectados pelo vírus determinante da Artrite-encefalite dos Caprinos, que no

transcurso da infecção apresentavam manifestações clínicas evidentes e características, estimaram que seriam entre 20 e $75 \%$ de caprinos infectados aqueles que apresentariam os sintomas típicos da 
doença (CRAWFORD e ADAMS, 1981; GONZÁLES et al., 1987; KRIEG e PETERHANS, 1990; GARCIA et al., 1992a). Por tal razão, no delineamento experimental deste trabalho realizado com caprinos criados no Estado de São Paulo, programou-se, associado ao levantamento imuno- sorológico a realização do exame clínico dos animais criados nos 14 plantéis avaliados. Os resultados demonstraram que entre 374 caprinos sororeagentes aos antígenos do vírus da Artrite-encefalite dos Caprinos, 17,1\% (64/374) apresentavam a forma clínica articular da doença e entre 249 cabras soropositivas, 6,8\% (17/249) apresentavam endurecimento da glândula mamária, manifestação clínica característica da forma mamária da Artrite-encefalite dos Caprinos. Esses resultados obtidos não concordam plenamente com os autores anteriormente mencionados, pois os valores da freqüência das manifestações clínicas encontradas em caprinos infectados pelo vírus, atingiu apenas o limiar mínimo relatados por eles, ou seja entre 20 e $75 \%$; isso se afirma pois a somatória dos casos de artrite $(17,1 \%)$ e de endurecimento mamário (6,8\%), alcançou valores de 23,9\%. Mesmo não sendo objeto de estudo desta pesquisa, foi conviniente afirmar-se nessa discussão que durante o período de controle dos rebanhos - 2000-2001, não foi diagnosticada a forma nervosa da Artrite-encefalite dos Caprinos, em nenhum dos 14 rebanhos, como descreveu SUNDQUIST et al. (1981).

A forma clínica da Artrite-encefalite dos Caprinos considerada prevalente foi a artrite, e isso, comprovou-se, cabalmente, nos 14 plantéis de caprinos Paulistas, acompanhados no período 2000/2001. Pois, observou-se que $17,1 \%$ dos 
caprinos sororeagentes positivos aos antígenos do vírus AEC apresentavam evidências clínicas de intenso processo inflamatório articular e periarticular e, que foram detectados utilizando métodos semiológicos descritos em ROSENBERGER (1983). Em contraposição, foram observados apenas 3,8\% de casos de artrite em caprinos não infectados pelo vírus AEC. A diferença observada entre os dois grupos experimentais foi estatisticamente significativa, podendo por isso afirmar-se a grande possibilidade de um caso clínico de artrite, em animal infectado pelo vírus AEC, ser causado pela ação deletéria deste vírus, ressaltando que tal afirmação concordou com as observações de RAMALHO (2000) que estudou comparativamente o potencial do vírus da Artrite-encefalite dos Caprinos e do Mycoplasma mycoides subesp. mycoides serem agentes determinantes de artrites nos caprinos.

Os resultados obtidos nesta tese deixaram evidentes as possibilidades de diagnóstico nosológico da doença, considerando a potencialidade do vírus determinar a forma clínica articular da Artrite-encefalite dos Caprinos e as manifestações clínicas resultantes e o diagnóstico nosológico poderia ser facilmente estabelecido pela avaliação do Índice Clínico Articular, como definido por STÜNZI et al. (1964), MONICAT (1987) e PERRIN et al. (1988), respeitando a caracterização de outros sintomas e lesões articulares definidas (CRAWFORD e ADAMS, 1981; NARAYAN e CORK, 1990; EAST, 1996). Todavia, haveria riscos na tendência de generalização do diagnóstico, tornando-o etiológico, pois demonstrou-se, na avaliação dos resultados desta pesquisa a possibilidade (36\% 36/100) da ocorrência de artrites em caprinos, cuja etiologia não estaria relacionada à infecção pelo vírus da AEC. Mas seria conveniente que os clínicos veterinários especializados em doenças de caprinos meditassem sobre duas proporções, dois contrastes possíveis de 
comparação ou relações que puderam ser tiradas dos presentes resultados: um caprino em 5,84 (374/64) possibilidades ou seja, para cerca de 6 caprinos sororeagentes aos antígenos do vírus da AEC, um apresentaria manifestações clínicas de artrite e; apenas um caprino entre 26,42 (951/36), ou aproximadamente 27 caprinos não infectados pelo vírus AEC, apresentaria sintomas característicos de artrite !

A forma clínica mamária, com manifestações evidentes de endurecimento do parênquima da glândula mamária e a diminuição da produção de leite foi, conceituada e caracterizada por WOODWARD et al. (1982) e as lesões definidas por KENNEDY-STOSKOPF et al. (1985), LERONDELLE et al. (1995), ROSADIO et al. (1993), SMITH e SHERMAN (1994) e SERAKIDES et al. (1996). A ocorrência do endurecimento do úbere foi demonstrada no acompanhamento clínico de 499 animais dos fatos de caprinos incluídos nesta tese de doutoramento, sendo os sintomas detectados e avaliados segundo as diretrizes semiológicas recomendadas por ROSENBERGER (1983). Na avaliação clínica, com destaque para o exame do úbere, observou-se que 6,8\% (17/249) cabras infectadas pelo vírus da Artrite- encefalite dos Caprinos apresentavam manifestações típicas da mamite endurativa, forma clínica característica das inflamações do tecido intersticial da glândula mamária determinadas pelo retromencionado vírus. O contraste comparando esse valor com aquele observado em cabras não infectadas pelo vírus AEC, 1,2\% (3/250), demonstrou que as diferenças eram estatisticamente significativas. Assim sendo, haveria grandes probabilidades do endurecimento progressivo da glândula mamária ser causado pelo vírus da Artrite-encefalite dos Caprinos. As probabilidades de diagnóstico etiológico dessas mamites endurativas seriam as seguintes: 1 para 
14,65 (249/17), ou seja, para cerca de 15 cabras infectadas pelo vírus AEC, uma apresentaria a forma clínica endurativa de mamite, característica para essa virose e; 1 para 83,33 (250/3), o que representaria a probabilidade de que em aproximadamente 84 cabras não infectadas pelo vírus AEC, uma apresenatria mamite crônica que determinaria o endurecimento do parênquima glandular. Além do mais os resultados dessa avaliação relacionando infecção pelo vírus da Artrite-encefalite dos Caprinos e ocorrência de mamites endurativas, permitiram afirmar-se que, 85\% (17/20) dessa forma clínica de mamite ocorreu em cabras infectadas pelo vírus AEC e apenas 15\% (3/20) foram demonstrada em cabras não reagentes aos antígenos do mencionado vírus.

Para ampliar o conhecimento sobre a Artrite-encefalite dos Caprinos, considerando seus aspectos clínico-epidemiológico, foi proposto, no delineamento experimental desta tese, algumas possibilidades de avaliação das vias de transmissão do vírus envolvido na enfermidade estudada. Assim, inicialmente, avaliou-se a transmissão vertical do vírus da Artrite-encefalite dos Caprinos, através da via vertical ou transplacentária, bem como a perinatal, ou seja, durante a parturição. Nessa avaliação utilizaram-se os resultados, obtidos em 26 cabritos nascidos de cabras soropositivas, e por isso, consideradas infectadas pelo vírus AEC. Em nenhum desses cabritos demonstrou-se a ocorrência da infecção por transmissão vertical do vírus. Portanto a probabilidade de infecção da Artriteencefalite dos Caprinos por via vertical (transplacentária ou durante a parturição foi menor do que $1: 26$, ou seja, menor do que $3,85 \%$. 
As observações obtidas pela avaliação dos resultados desta pesquisa, permitiram afirmar plena concordância com o que fora exposto por NARAYAN e CORK (1990), quando relataram que a infecção transplacentária ao feto durante seu desenvolvimento intra-uterino pareceu não ser a via de maior importância na disseminação da doença, e por isso e pelos resultados obtidos discordou-se da hipótese da importância epidemiológica da transmissão transplacentária ou peri parturição referidas por ADAMS et al. (1983). Pois na observação desses pesquisadores, em dois cabritos supostamente infectados por via transplacentária soroconverteram-se, um aos 4 meses de idade e o outro aos 32 meses de idade. Discordou-se também das conclusões de COFFIN (1996), que em suas considerações aventaram a possibilidade da ocorrência da transmissão vertical transplacentária do vírus AEC, a semelhança do que ocorria com outros retrovírus, em algumas espécies de animais domésticos.

O delineamento experimental proposto para verificar as possibilidades de transmissão do vírus da Artrite-encefalite dos Caprinos pela ingestão de colostro e leite de cabras infectadas pelo mencionado vírus e, assim sendo contribuir para a elucidação de algumas possibilidades de transmissão por via horizontal, estudaram-se a soroconversão em cabritos recém-nascidos incluídos em três grupos experimentais: Grupo A - 14 cabritos crias de cabras infectadas, aleitamento com colostro de cabra infectada e leite de cabra sadia ou leite de vaca em pó; Grupo B - 21 cabritos crias de cabras infectadas, aleitamento com colostro de cabras infectadas e leite de cabra infectada; Grupo C - 16 cabritos crias de cabras sadias, aleitamento com colostro de cabras sadias e a seguir leite de cabra infectada. Os cabritos tiveram amostras de soro sangüíneo avaliadas antes da ingestão do colostro, e 12 e 24 horas após a ingestão do 
colostro e a seguir periodicamente até 180 dias de vida. No delineamento experimental proposto comprovou-se, que no Grupo A, nenhum dos cabritos demonstrou ter-se infectado pelo vírus da Artrite-encefalite dos Caprinos pela ingestão do colostro de cabras infectadas $(0 \%$ - 0/14). Igual resultado obteve-se no Grupo B, pois nenhum dos 16 cabritos crias de cabras infectadas, e aleitados com colostro e leite de cabras infectadas não demonstraram sinais imunológicos da infecção ( $0 \%$ 0/21). Em contraposição, 3 (18,8\%) cabritos crias de cabras sadias, que receberam colostro de cabras sadias, mas foram aleitados com leite de cabras infectadas, demonstraram evidências imunosorológicas de infecção pelo vírus da Artrite-encefalite dos Caprinos (18,8\% - 3/16).

A avaliação dos resultados obtidos nos três grupos experimentais destacou três fatos bem evidenciados: 1. o colostro não demonstrou, por sua ingestão, capacidade de infectar cabritos recémnascidos, pois apresenta condições biológicas de proteger o recém-nascido da possível transmissão, além do mais, deveria ser admissível a possibilidade do suco gástrico do abomaso destruir o vírus; 2. a ingestão de leite de cabras infectadas durante o aleitamento de cabritos protegidos pela imunidade passiva transferida pela ingestão do colostro, foi suficiente para impedir a infecção dos cabritos; 3. os cabritos recémnascidos crias de cabra sadias e que mamaram imediatamente após o nascimento colostro dessas cabras ao serem aleitadas com leite de cabras infectadas, se infectaram em $18,8 \%$ dos casos (18,8\%3/16). A probabilidade desse tipo de transmissão foi de 1:5,3, ou seja, praticamente, de cinco cabritos assim aleitados um teria possibilidade de infectar-se pelo vírus da Artrite-encefalite dos Caprinos. 
O pleno conhecimento das inúmeras possibilidades de infecção do gado caprum pelo vírus da Artrite-encefalite dos Caprinos não foi ainda alcançado, apesar dos significativos resultados conseguidos nesta tese. A divulgação desses resultados, seguramente, seria por si só a fonte geradora de inúmeras controvérsias, principalmente porque conceitos afirmados nos pioneiros trabalhos sobre o assunto e que eram simplesmente repetidos como dogmas e aceitos como verdade definitiva, foram contestados ou confirmados de forma experimental consistente. Faltou, às pesquisas epidemiológicas e imuno-sorológicas, uma avaliação moderadora, como recomenda, a moderna Patologia e Clínica Veterinárias, baseada no diuturno acompanhamento dos fatos de caprinos, infectados por esse Lentivirus. Assim sendo, pela analise dos resultados contestou-se em parte as afirmações de CRAWFORD e ADAMS (1981), ADAMS et al. (1983), EAST et al. (1987) e ROWE et al. (1992) que afirmaram categoricamente que os cabritos se infectam pela ingestão de colostro e leite de cabras infectadas pelo vírus AEC. Talvez em algumas circunstâncias houve confusão entre soroconversão por transferência passiva de anticorpos e aquela permanente causada por infecção ativa, apesar de vários dos pesquisadores referidos conhecerem a soroconversão determinada pela ingestão de colostro; além do mais, em suas avaliações eles não isolaram ou impediram a transmissão horizontal por outras causas, como por exemplo a possível transmissão pela inseminação artificial ou cobertura natural (TRAVASSOS et al., 1999). ROWE et al. (1992) afirmaram que cabritos alimentados com leite de cabras infectadas, apresentavam 3,3 vezes mais chances de se infectarem pelo vírus, porém não isolaram ou impediram outras formas de transmissão, pois observaram de cabritos crias de cabras infectadas, alimentados 
com leite pasteurizado, apresentavam 10\% de soroconversão aos seis meses de idade. Observação que não concordaram com fatos demonstrados na presente pesquisa.

Os caprinos constituintes dos grupos experimentais, nos quais se avalia transmissão do vírus AEC por ingestão de colostro ou leite de cabras infectadas permitiu que se acompanhasse, em cabritos que receberam $200 \mathrm{ml}$ de colostro de cabras soropositivas, a dinâmica dos anticorpos séricos antivírus da Artrite-encefalite dos Caprinos. Esses cabritos tornavam-se soropositivos logo após mamarem o colostro das cabras infectadas e a análise dos resultados permitiu que se determinasse o período de permanência dos anticorpos séricos antivírus da AEC, passivamente transferidos pela ingestão de colostro de cabras soropositivas. Essa observação feita em 35 cabritos, demonstrou que os referidos anticorpos foram detectados no soro dos caprinos entre 60 e 120 dias de vida, concordando com os resultados, anteriormente referidos nos estudos de CRAWFORD e ADAMS (1981), ADAMS et al. (1983) e BULGIN (1990). Os resultados desta tese permitiram afirmar que a dinâmica dos anticorpos, variava de acordo com características individuais e que a frequiências de permanência de anticorpos séricos antivírus da Artrite-encefalite de origem passiva, nos cabritos que constituiram o presente modelo experimental foram as seguintes: $35 / 35$ (100\%) aos 30 dias; 10/35 $(28,6 \%)$ aos 60 dias; $3 / 35(8,6 \%)$ aos 90 dias e $0 / 35(0 \%)$ aos 120 dias de idade. Assim sendo, houve em todos os animais avaliados, o esgotamento dos anticorpos antivírus da AEC de origem colostral após os 90 dias de idade.

Para elucidar algumas dúvidas que poderiam perssistir após a avaliação da possível transmissão do vírus AEC pela ingestão do colostro ou do leite, como também outros modos possíveis de transmissão horizontal do vírus causador da

Artrite-encefalite dos Caprinos, foi proposto no delineamento experimental desta pesquisa a verificação da viabilidade do vírus, quer fossem com partículas livres, no colostro ou no leite, ou como participante do genoma de células somáticas da secreção láctea, pois SMITH e SHERMAN (1994) destacaram que elas manteriam a potencialidade de serem infectante. Por tal razão, foram constituídos 
outros três grupos experimentais, cada um constituído por cinco cabritos, com cerca de 6-8 meses de idade, sororeagentes negativos aos antígenos do vírus AEC e que foram, cada caprino dos três grupos experimentais, inoculados com colostro, leite e por sangue contaminados pelo vírus da Artriteencefalite dos Caprinos.

Os resultados obtidos na presente pesquisa demonstraram que $100 \%(5 / 5)$ dos caprinos tatuados usando equipamento contaminado com sangue de caprino infectado pelo vírus da Artriteencefalite dos Caprinos; comprovaram ainda que o tamanho do inoculo injetado pelo uso do tatuador contaminado foi suficiente para infectar caprino tatuado. Ressalte-se, ainda que $20 \%$ dos caprinos inoculados por tatuador soroconverteram 45 dias após o processamento da tatuagem, os demais $80 \%$ (4/5) tornaram-se sororeagentes 60 dias após a inoculação. Assim sendo, demonstrou-se de forma categórica a possibilidade da transmissibilidade iatrogenica por via horizontal do vírus da Artriteencefalite dos Caprinos; concordando assim com afirmações de SMITH e SHERMAN (1994) e, discordou-se, entretanto, das observações de PERRIN e POLACK (1987) que negavam possibilidade da transmissão horizontal iatrogênica pelo uso indiscriminado e seriado de seringas, agulhas e tatuadores contaminados com sangue de caprinos infectados. Além do mais, outras possibilidades de transmissão horizontal do vírus da Artrite-encefalite dos Caprinos já haviam sido detectadas por ADAMS et al. (1983). 
Apesar das vias de transmissão e a forma como elas ocorreriam não serem ainda consideradas como definitivamente esclarecidas, aparentemente estabeleceu um conceito, que não pôde, pelos resultados obtidos nesta tese, ser considerado como totalmente correto, definindo: que a ingestão do colostro e leite de cabras infectadas seriam o elo mais significativo na infecção dos animais susceptíveis. Tais conceitos foram estabelecidos e aceitos por conceituados pesquisadores: CRAWFORD e ADAMS (1981), ADAMS et al. (1983), EAST et al. (1987), SMITH e SHERMAN (1994).

ROWE et al. (1991) e ROWE et al. (1992), além de aceitarem a transmissão do vírus da Artrite-encefalite dos Caprinos pela ingestão de colostro e leite comprovaram a infecção de cabras leiteiras pela inoculação de leite de cabra infectada por via intramamária, extendendo essa possibilidade pelo manejo da ordenha, manual ou mecânica. Os resultados ora obtidos não permitiram que se desse tal importância como via de transmissão do vírus da Artrite-encefalite dos Caprinos, pois em 53 cabritos que receberam colostro ou aleitamento com leite de cabras infectadas, apenas três (5,9\%-3/51) foram infectados pelo mencionado vírus.

O discrepante resultado desta tese com os referidos na literatura compulsada, obrigou que se avaliasse a viabilidade do vírus AEC no colostro e no leite e sua capacidade de infectar animais susceptíveis. Nestas circunstâncias o delineamento experimental programou inocular $5 \mathrm{ml}$ de colostro e de leite de cabras infectadas por via intramuscular. O resultado obtido nos dois grupos experimentais demonstraram plena atividade e capacitação infectiva do vírus, que estivessem como partículas livres ou no interior das células somáticas do leite (SMITH e SHERMAN, 1994), pois os 10 caprinos utilizados nestes experimentos soroconverteram, 
demonstrando "status" de infectado 60 dias após a inoculação. Os resultados destacaram que 20\% (1/5) dos caprinos apresentavam a infecção, comprovada pela soroconversão e os demais 80\% (4/5) 60 dias depois da inoculação. Tais resultados da soroconversão foram obtidos pela prova da imunodifusão em gel de ágar, porém quando as amostras foram examinadas pelo teste imunoenzimático - ELISA a soroconversão foi mais precoce, nos cabritos inoculados com leite de caprino infectado, pois $80 \%$ deles (4/5) demonstraram a infecção pela soroconversão 45 dias após a inoculação. Tais resultados confirmaram as conclusões apresentadas por KENNEDY-STOSKOPF et al. (1985) e NARAYAN e CORK (1990) em relação ao período de incubaçào e com HOWERS et al. (1982) ao demonstrar a maior sensibilidade dos testes ELISA na detecção do momento da soroconversão.

Outro objetivo proposto no delineamento experimental desta pesquisa foi o de avaliar a constituição protéica e a capacidade de transferência de imunoglobulinas e de gamaglutamiltransferase - $\gamma \mathrm{GT}$, passivamente aos cabritos neonatos pela ingestão do colostro, tanto em cabritos crias de cabras infectadas e não infectadas pelo vírus da Artrite-encefalite dos Caprinos.

A dinâmica do proteinograma, avaliada em cabritos que ingeriram colostro de cabras sororegentes negativas e sororeagentes positivas aos antígenos dos vírus da AEC, foi similar, respectivamente: proteína total sérica antes da ingestão do colostro igual a 3,73 $\pm 0,61 \mathrm{~g} / \mathrm{dl}$ e 3,75

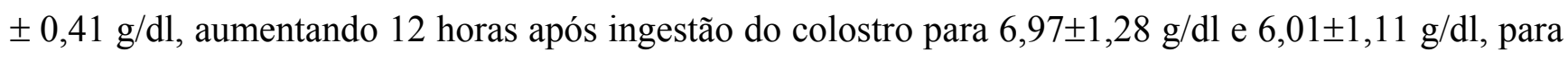
a seguir apresentarem oscilações de pequena amplitude, não sendo as diferenças estatisticamente significativas; a fração gamaglobulina, antes da ingestão do colostro se equivaliam 
sendo iguais a $0,39 \pm 0,13 \mathrm{~g} / \mathrm{dl}$ e $0,48 \pm 0,24 \mathrm{~g} / \mathrm{dl}, 12$ horas após a ingestão do colostro os teores de gamaglobulinas aumentaram significativamente e houve diferença evidente entre o teor de gamaglobulina dos cabritos que mamaram colostro de cabras negativas $(3,01 \pm 1,27 \mathrm{~g} / \mathrm{dl})$ valores significativamente maiores do que os observados nos cabritos que mamaram colostro de cabras positivas $(2,10 \pm 0,90 \mathrm{~g} / \mathrm{dl})$, a seguir até 180 dias de vida os dois grupos apresentaram variações de pequena magnitude.

Em relação aos valores da atividade sérica da enzima gamaglutamiltranferase - $\gamma \mathrm{GT}$, observou-se de forma semelhante à descrita por THOMPSON e PAULI, 1981 e confirmada recentemente, por FEITOSA (1998) em bovinos, que os cabritos antes de mamarem o colostro

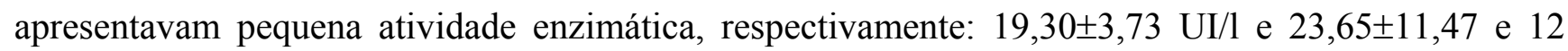
horas após a ingestão do colostro os cabritos dos dois grupos experimentais demonstraram evidente aumento de atividade desta enzima. Entretanto, os valores entre os grupos apresentavam diferenças estatisticamente significativas: cabritos após ingestão de colostro de cabras negativas apresentavam 467,62 $\pm 260,67$ UI/1, significativamente maior do que o valor médio do grupo de cabritos que ingeriram colostro decabras positivas - 265,89 $\pm 130,30$ UI/1. a seguir a atividade diminuiu gradativamente com o evoluir da idade.

Em termos gerais, considerados os resultados médios obtidos os resultados e variações do proteinograma concordaram com os referidos na literatura por FERRI et al. (1970), BIRGEL et al. (1971), BEHERA et al. (1993); LEAL (2001) e BARIONI et al. (2001). Por ter-se obtidos maiores valores, na presente pesquisa, discordou-se dos resultados referidos por BIRGEL e ARAUJO (1968) e 
BIRGEL (1969), pois os referidos pesquisadores dosaram a gamaglobulina sérica por método turbidimétrico. Discordou-se por serem menores os valores referidos por CASTRO et al. (1977).

Os resultados obtidos nesta tese demonstraram que o fracionamento da fração protéica gamaglobulina e a dosagem da atividade sérica da enzima gamaglutamiltransferase - $\gamma \mathrm{GT}$ são parâmetros que demonstraram de forma irrefutável a absorção de imunoglobulinas por ingestão do colostro. Além do mais, esses parâmetros demonstraram ter havido, nos dois grupos experimentais (cabritos que ingeriram colostro de cabras infectadas pelo vírus AEC e cabritos que ingeriram colostro de cabras sadias), suficiente absorção de imunoglobulinas e adequada transferência de imunidade passiva por ingestão de colostro. Isso se deu, em quantidade suficiente para impedir - associado a outros fatores orgânico/funcionais a infecção de cabritos neonatos, que foram aleitados com colostro e leite de cabras infectadas pelo vírus da Artrite-encefalite dos Caprinos. 


\section{CONCLUSÕES}

A avaliação dos resultados dos vários grupos experimentais formados em obediência ao delineamento experimental desta tese, objetivando estudar características clínico-epidemiológicas da infecção pelo vírus da Artrite- encefalite dos Caprinos, em 14 cabris localizados em 13 municípios do estado de São Paulo, no período de 2000-2001, permitiram firmar as conclusões a seguir detalhadas.

1- Artrite-encefalite dos Caprinos foi considerada uma enfermidade endêmica no estado de São Paulo, pois 71,4\% (10/14) dos plantéis avaliados apresentavam caprinos sororeagentes positivos ao vírus determinante dessa infecção.

2- A freqüência de amostras colhidas de caprinos portadores de anticorpos da Artrite-encefalite dos Caprinos nos 14 cabris, no período 2000-2001 foi igual a 26, 3\%.

3- A prevalência da Artrite-encefalite dos Caprinos foi significativamente maior nos caprinos das raças Anglo Nubiana (63,8\% - 88/138) e Toggenbourg (56,0\% - 28/50) do que nas demais raças estudadas: Saanen $(27,4 \%$ - 673/2458), alpina (11,9\% - 59/497), Bôer (5,9\% - 2/34) e caprinos mestiços $(10,7 \%-11 / 103)$.

4- Não se detectou influência de fatores sexuais sobre a prevalência da Artrite-encefalite dos Caprinos determinada em caprinos do sexo feminino $(27,9 \%$ - 663/2375) e masculino $(32,3 \%$ 94/291). 
5- A freqüência da ocorrência da infecção pelo vírus da Artrite-encefalite dos Caprinos aumentou gradativa e significativamente após os 6 meses de idade, havendo predominância da infecção nos caprinos mais velhos.

6- A prevalência da Artrite-encefalite dos Caprinos foi significativamente maior nos caprinos submetidos ao regime intensivo de criação $(31,8 \%$ - 733/2303), do que nos mantidos em regime semi-extensivo de criação (13,1\% - 128/977).

7- O exame semiológico de caprinos demonstrou, predominante ocorrência de duas formas clínicas da Artrite- encefalite dos Caprinos:

a- a forma clínica articular foi demonstrada em 17,1\% (64/374) dos caprinos sororeagentes aos antígenos do vírus da Artrite-encefalite dos Caprinos;

b- A forma clínica mamária (mamite endurativa) foi detectada em 6,6\% (17/249) das cabras sororeagentes aos antígenos do vírus da Artrite-encefalite dos Caprinos.

8- Entre 26 cabritos recém-nascidos, crias de cabras infectadas pelo vírus da Artrite-encefalite dos Caprinos, nenhum nasceu sororeagente positivo, aos antígenos do vírus, o que indicou ser a possibilidade de transmissão vertical transplacentária da infecção menor do que 3,8\%.

9- Os cabritos neonatos que ingeriram colostro de cabras infectadas pelo vírus da Artrite-encefalite dos Caprinos tornaram-se sororeagentes imediatamente, após a mamada do colostro; esses anticorpos passivamente transferidos permaneceram no sangue circulante durante um período que variou entre 60 e 120 dias. 
10- Nos grupos experimentais avaliados demonstrou-se ser pequena a possibilidade da transmissão da Artrite-encefalite dos Caprinos, pela ingestão de colostro ou de leite de cabras infectadas, pois:

a- em nenhum dos cabritos neonatos, aleitados com colostro de cabra infectada e leite de caprinos sadios ou leite de vaca em pó, se detectou aos 180 dias de vida, presença de anticorpos séricos antivírus da Artrite-encefalite dos Caprinos;

b- em nenhum dos cabritos recém-nascidos, crias de cabras infectadas pelo vírus da Artrite-encefalite dos Caprinos, aleitados com colostro e leite de cabras sadias, se detectou aos 180 dias de vida, presença de anticorpos séricos antivírus da Artrite-encefalite dos Caprinos;

c- em apenas 18,8\% (3/16) cabritos neonatos, crias de cabras sadias, aleitados com colostro desses animais e aseguir com leite de caprinos infectados pelo vírus da Artrite-encefalite dos Caprinos, demonstrou-se, aos 180 dias de vida, a ocorrência da infecção determinada pelo referido vírus.

11- Demonstrou-se, indiretamente, a presença, viabilidade e patogenicidade do vírus da Artriteencefalite dos Caprinos no sangue circulante, colostro e leite de caprinos infectados, bem como a possibilidade desses fluídos orgânicos infectarem animais susceptíveis, por inoculação, pois:

a- todos dos cabritos sadior inoculados por tatuagens feitas com tatuador contaminado com sangue de caprinos sororeagentes positivos ao mencinado vírus, apresentaram soroconversão persistente, 
comprovando-se a possibilidade de transmissão horizontal iatrogênica da infecção da Artriteencefalite dos Caprinos;

b- todos os cabritos inoculados por via intramuscular, tanto com colostro, como também com leite de cabras infectadas demonstraram soroconversão persistente.

12- Demonstrou-se que o período de incubação do vírus da Artrite-encefalite dos Caprinos em infecções determinadas por inoculção experimental variou entre 45 e 60 dias pós inoculção, sendo o teste imunoenzimático - ELISA, mais sensível do que a prova de imunodifusão em gel de ágar, pois pôde detectar os anticorpos antivírus mais precocemente.

13- Em cabritos neonatos utilizados nos testes de comprovação da viabilidade da transmissão vertical ou horizontal do vírus da Artrite-encefalite dos Caprinos, realizados nesta tese, demonstrou-se adequada transferência de imunidade passiva pela ingestão do colostro, pois:

a- não foram detectadas diferenças significativas dos teores séricos de proteína total e da atividade enzimática da gamaglutamiltransferase - $\gamma$ GT em cabritos que receberam colostro de cabras infectadas ou não infectadas pelo mencionado vírus;

b- os significativos aumentos da fração sérica de globulina e da atividade enzimática de $\gamma \mathrm{GT}$, representaram bons indicadores do "status" da imunidade dos recém-nascidos que receberam, tanto colostro de cabras infectadas, como também das não infectadas pelo vírus da Artriteencefalite dos Caprinos; 
c- apesar dos cabritos recém-nascidos, que receberam colostro de cabras não infectadas pelo vírus da Artrite- encefalite dos Caprinos terem no primeiro dia de vida, valores séricos de gaglobulina significativamente maiores do que os determinados em cabritos que receberam colostro de cabras infectadas, eles foram, em ambos grupos, suficientes para participar da proteção desses cabritos contra infecções que pudessem ser transmitidas pela ingestão de leite contendo partículas virais.

14- Tanto a determinação sérica do teor de gamaglobulina, como a avaliação da atividade enzimática da gamaglutamiltransferase representaram bons indicadores de adequada transferência de imunidade passiva pela ingestão de colostro aos cabritos recém-nascidos. 


\section{REFERÊNCIAS}

ADAIR, B. M. Serological surveilance for maedi-visna virus and caprine arthritis-encephalitis virus in North Ireland. Veterinary Record, v. 118, n. 15, p.422-423, 1986.

ADAMS, D. S.; CRAWFORD, T. B.; KLEVJER-ANDERSON, P. A pathogenic study of early connective tissue lesions of viral caprine arthritis-encephalitis. American Journal of Pathology, v. 99, n. 2, p. 257-271, 1980.

ADAMS, D. S.; GOGOLEWSKI, R. P.; BARBET, A. F.; CHEEVERS, W. P. Identification of caprine arthritis-encephalitis retrovirus proteins in immunodiffusion preciptin lines. Journal of General Virology, v. 66, n. 5, p. 1139-1143, 1985.

ADAMS, D. S.; KLEVJER-ANDERSON, P.; CARLSON, J. L.; McGUIRE, T. C.; GORHAM, J. R. Transmission and control of caprine arthritis-encephalitis virus. American Journal Veterinary Research, v. 44, n. 9, p. 1670-1675, 1983.

ADAMS, D. S.; OLIVER, R. E.; AMEGGHINO, E.; DEMARTINI, J. C.; VERWOERD, D. W.; HOWERS, D. J.; WAGUELA, S.; GOHAN, J. R.; HYLSETH, B.; DAWSON, M.; TRIGO, F. J.; MCGUIRRE, T. C. Global survey of serological evidence of caprine arthritis-encephalitis virus infection. Veterinary Record, v. 115, n. 19, p. 493-495, 1984.

AGRIMI, P.; BRACA, G.; LEGROTTAGLIE, R.; RENZONI, G.; TACCINI, E.; TOLARI, F. Caprine arthritis and encephalitis virological studies and clinical and pathological observations. Summa, v. 3, n. 2, p. 95-100, 1986.

AGRiMI, P.; LegrotTaglie, R.; TOlARI, F.; RENZONI, G.; LETO, A.; ORLANDO, F. Isolamento di un virus riferibile a CAEV (caprine arthritis-encephalitis virus) da capre di razza Saanen con sintomi di artrite ed encefalite. Atti della Societá Italiana delle Scienze Veterinaire, v. 39, n. 2, p. 694-696, 1985.

AL-ANI, F. K.; VESTWEBER, G. E. Caprine arthritis-encephalitis syndrome (CAE): A review. Veterinary Research Communications, v. 8, n. 4, p. 243-253, 1984.

ARCHAMBAULT , D.; EAST, N.; PERK, K.; DAHLBERG, J. E. Development of an enzyme-linked immonosorbent assay for caprine arthritis-encephalitis virus. Journal of Clinical Microbiology, v. 26, n. 5, p. 971-975, 1988.

ASSIS, A. P. M. V.; GOUVEIA, A. M. G. Evidências sorológicas de Lentivirus (Maedi/Visna/ArtriteEncefalite Caprina) em rebanhos nos Estados de MG., RJ., BA e CE. In: CONGRESSO BRASILEIRO DE MEDICINA VETERINÁRIA, 23, 1994, Olinda, Pernambuco. Anais... p. 104. 
BARIONI, G.; FONTEQUE, J. H.; PAES, P. R. O.; TAKAHIRA, R. K.; KOHAYAGAWA, A.; LOPES, R. S.; LOPES, S. T. A.; CROCCI, A. J. Valores séricos de cálcio, fósforo, sódio, potássio e proteínas totais em caprinos Fêmeas da raça Parda Alpina. Ciência Rural, v. 31, n. 3, p. 435-438, 2001.

BEHERA, P. C.; BISOI, P. C.; MOHANTY, B. P.; PANDA, G. M. Clinically important serum constituents of black bengal goats. Indian Veterinary Journal, v. 70, n. 8, p. 713-717, 1993.

BÉLANGER, D.; LEBOEUF, A. CAE - Virus seroprevalence in mixed goat herd. Veterinary Record, v. 133, n. 13, p. 328, 1993.

BERQUÓ, E. S.; SOUZA, J. M. P.; GOTLIES, S. L. D.

Bioestatística. São Paulo:

Pedagógica e Universitária, 1981.350p.

BIRGEL, E. H. Artrite-encefalite dos Caprinos . São Paulo: Capripaulo ( $6^{\circ}$. Encontro nacional para o Desenvolvimento da Espécie Caprina), 2000. 38 p. Apostila.

BIRGEL, E. H.; FERRI, S.; MEDEIROS, L. O. Études par électrophorèse sur papier des protéines du sérum normal des chèvres anglo-nubiennes. Recueil de Médicine Vétérinaire, v. 147, n. 1, p. 43-48, 1971.

BIRGEL, E. H. Leucose linfática e enzoótica dos bovinos adultos, aspectos clínicos e diagnóstico. In: BIRGEL, E. H.; BENESI, F. J. Patologia clínica veterinária. São Paulo: Sociedade Paulista de Medicina Veterinária, 1982. p. 242-260.

BIRGEL, E. H. Variações dos teores protéicos do sangue de caprinos durante o desenvolvimento etário. Revista da Faculdade de Medicina Veterinária, São Paulo, v. 8, n. 1, p. 299-315, 1969.

BIRGEL, E. H.; ARAUJO, L. M. Quadro protéico de fêmeas da espécie caprina (Capra hircus), criadas no Estado de São Paulo. Revista da Faculdade de Medicina Veterinária, São Paulo, v. 7, n. 4, p. 953-968, 1968.

BOHLAND, E. Artrite encefalite caprina: avaliação dos aspectos produtivos e reprodutivos de animais infectados e não infectados. 1998. 95 f. Dissertação (Mestrado em Clínica Veterinária) Faculdade de Medicina Veterinária e Zootecnia, Universidade de São Paulo, São Paulo.

BÖNI, 1961 apud STÜNZI et al., 1964.

BÜCHI, 1959 apud STÜNZI et al., 1964.

BULGIN, M. S. Ovine progressive pneumonia, caprine arthritis-encephalitis, and related lentiviral disease of sheep and goats. Veterinary Clinics of North America: Food Animal Practice, v. 6, n. 3, p. 691-704, 1990. 
CAPORALE, V. P.; BALBO, S.; LELli, R.; SEMPRONI, G.; CACCIA, A.; BALDELli, R. Investigation on lentivirus infection in italian caprine population. Zentralblatt für Veterinärmedizin, v. 32, n. 9, p. 652-659, 1985.

CAStro, A. A cabra. 3. ed. Rio de Janeiro: Freitas Bastos, 1984. 372 p.

CASTRO, A.; DHINDSA, D. S.; HOVERSLAND, A. S.; METCALFE, J. Serum proteins and protein electrophorectic pattern in normal pygmy goats. American Journal of Veterinary Research, v. 38, n. 5, p. 665-667, 1977.

CASTRO, R. S.; LEITE, R. C.; RESENDE, M.; GOUVEIA, A. M. G. A Labelled avidin-biotin ELISA to detect antibodies to Caprine Arthritis-encephalitis vírus in goat's sera. Veterinary Research Communications, v. 23, n.2, p. 515-522, 1999a.

CASTRO, R. S.; LEITE, R. C.; RESENDE, M.; MARTINS, A.; GOUVEIA, A. M. G. Isolamento e identificação pela imunofluorescência direta e reação em cadeia de polimerase do vírus da artriteencefalite caprina. Arquivo Brasileiro de Medicina Veterinária e Zootecnia, v. 51, n. 3, p. 235240, $1999 b$.

CLAVIJO, A.; THORSEN, J. Application of polymerase chain reaction for the diagnosis of caprine arthritis-encephalitis. Small Ruminant Research, v. 22, n.1, p. 69-77, 1996.

COFFIN, J. M. Retroviridae: The viruses and their replication. In: FIELDS, B.N.; KNIPE, D.M.; HOWLEY, P.M. Fundamental Virology. Philadelphia: Lippincott-Raven, 1996. p. 763-843.

CORK, L. C. Differential diagnosis of viral leukoencephalomyelitis of goats. Journal of American Veterinary Medical Association, v. 19, n. 12, p. 1303-1306, 1976.

CORK, L. C.; HADLOW, W. J.; CRAWFORD, T. B.; GORHAM, J. R.; PIPER, R. C. Infectious leukoencephalomyelitis of young goats. Journal of Infectious Diseases, v. 129, n. 2, p. 134-141, 1974.

CRAWFORD, T. B.; ADAMS, D. S. Caprine arthritis-encephalitis: clinical features and presence of antibody in selected goat populations. Journal of American Veterinary Medicine Association, v. 178, n. 7, p. 713-719, 1981.

CRAWFORD, T. B.; ADAMS, D. S.; CHEEVERS, W. P.; CORK, L. C. Chronic arthritis in goats caused by a retrovirus. Science, v. 207, n. 29, p. 997-999, 1980.

CUNHA, R. G.; NASCIMENTO, M. D. Ocorrência de anticorpos para o vírus da artrite-encefalite caprina em soros de caprinos do Estado do Rio de Janeiro. Revista Brasileira de Medicina Veterinária, v. 17, n. 2, p. 72-75, 1995. 
CUTLIP, R. C.; JACKSON, T. A.; LAIRD, G. A. Immunodifusion test for Ovine Progressive Pneumonia. American Journal of Veterinary Research, v. 38, n. 7, p. 1081-1084, 1977.

CUTLIP, R. C.; LEHMKUHL, H. D.; SACKS, J. M.; WEAVER, A. L. Prevalence of antibody to caprine arthritis-encephalitis virus in goats in the United States. American Journal Veterinary Research, v. 200, n. 6, p. 802-805, 1992.

D’AngelinO, J. L.; GARCIA, M.; BAStOS, P. S.; MOURÃO, M. A. F.; BOHLAND, E. Ocorrência da artrite encefalite caprina no Estado de São Paulo - Brasil. Arquivos da Escola de Medicina Veterinária da Universidade Federal da Bahia, v. 16, n. 1, p. 60-66, 1993.

DAWSON, M.; WILESMITH, J. W. Serological survey of lentivirus (maedi visna/caprine arthritisencephalitis) infection in British goat herds. Veterinary Record, v. 117, n. 4, p. 86-89, 1985.

DEVENDRA, C.; BURNS, M. Goat production in the tropics. Reino Unido: Unwin Brothers, 1983. $183 \mathrm{p}$.

EAST, N. E. Caprine arthritis encephalitis. In: SMITH, B. P. Large animal internal medicine. 2. ed. St. Louis: Mosby, 1996. p. 1147-1148.

EAST, N. E.; ROWE, J. D.; MADEWEL, B. R.; FLOYD, K. Serologic prevalence of caprine arthritisencephalitis virus in California goat dairies. Journal of American Veterinary Medical Association, v. 190, n. 2, p. 182-186, 1987.

ELLIS, T. M.; CARMAN, H.; ROBINSON, W. F.; WILCOX, G. E. The effect of colostrum-derived antibody on neonatal transmission of caprine arthritis-encephalitis virus infection. Australian Veterinary Journal, v. 63, n. 8, p. 242-245, 1986.

ELLIS, T. M.; ROBINSON, W. F.; WILCOX, G. E. Characterisation, experimental infection and serological response to caprine retrovirus. Australian Veterinary Journal, v. 60, n. 11, p. 321-326, 1983.

ELLIS, T. M.; ROBINSON, W. F.; WILCOX, G. E. The pathology and aetiology of lung lesions in goats infected with caprine arthritis-encephalitis virus. Australian Veterinary Journal, v. 65, n. 3, p. 69-73, 1988.

FAO - Food and Agriculture Organization of the United Nations. Animal Yearbook, n. 32, 1993.

FEITOSA, F. L. F. Dinâmica do proteinograma e da atividade da gamaglutamiltransferase no soro sangüíneo de bezerros desde o nascimento até um ano de vida e de vacas antes e após o parto, da raça Holandesa. 1998. 219 f. Tese (Doutorado em Clínica Veterinária) - Faculdade de Medicina Veterinária e Zootecnia, Universidade de São Paulo, São Paulo. 
FERNANDES, M. A. Artrite encefalite caprina - Contribuição para o estudo epidemiológico em rebanhos leiteiros criados no Estado de São Paulo. 1997. 83 f. Dissertação (Mestrado em Clínica Veterinária) - Faculdade de Medicina Veterinária e Zootecnia, Universidade de São Paulo, São Paulo.

FERRI, S.; BIRGEL, E. H.; SILVA, R. A. P. S. Electrophoretic study of seric proteins in normal Toggenburg female goats with aging. Archivo Veterinário Italiano, v. 21, n. 2/3, p. 119-125, 1970.

FITERMAN, I. R. Constatação do complexo artrite-encefalite em um plantel de caprinos no Estado da Bahia. In: CONGRESSO BRASILEIRO DE MEDICINA VETERINÁRIA. 21., 1988, Salvador. Anais... Salvador: Sociedade Brasileira de Medicina Veterinária, 1988. p. 33.

FRANCKI, R. I. B.; FAUQUET, C. M.; KNUDSON, D. L. BROWN, F. M. Classification and nomenclature of viruses. Archives of Virology, p. 450, 1991, Supplementum 2.

FRIEDMAN, H. S. A standardized procedure for serum protein eletrophoresis in celulose acetate membrane strips. Clinica Chimica Acta, v. 6, n. 3, p. 775-781, 1961.

GARCIA, M.; GALHARDO, M.; ARAÚJO, W. P.; D’ANGELINO, J. L.; BASTOS, P. S.; ROSSINI, A. J. Caprine arthritis-encephalitis (CAE). Occurrence of positive sera in goats raised in Brazil. Tropical Animal Health and Production, v. 24, n. 3, p. 164, 1992a.

GARCIA, M., ROSSINI, A. J.; GALHARDO M.; ARAÚJO, W. P.; BASTOS, P. A. S.; D’ANGELINO, J. L. Índice clínico no diagnóstico e profilaxia da artrite-encefalite caprina. Arquivo Brasileiro de Medicina Veterinária e Zootecnia, v. 44, n. 4, p. 263-270, 1992 b.

GEORGE, L. W. Caprine arthritis encephalitis. In: SMITH, B. P. Large animal internal medicine. 2. ed. St. Louis: Mosby, 1996. p. 905-906.

GONZALES, L.; GELABERT, J. E.; MARLO, J. C.; SAEZ de OKARIZ, C. Caprine arthritisencephalitis in the Basque country, Spain. Veterinary Record, v. 120, n. 5, p. 102-109, 1987.

GORNALL, A. G.; BARDAWILL, C. J.; DAVID, M. M. Determination of serum protein by means of biuret reaction. Journal of Biological Chemistry, v. 177, n. 2, p. 751-766, 1949.

GRANT, G. H.; JOHNACHAN, P. M.; OLIVEIRA, D.; PITTERSON, S. The soroprevalence of caprine arthritis-encephalitis (CAE) in Jamaica goat population. Etudes-et-Syntheses-de I'IEMVT, n. 42 , p. 60-66, 1993. 
GREENWOD, P. L. Effects of caprine arthritis-encephalitis virus on productivity and health of dairy goats in New South Wales, Australia. 1995.

Preventive Veterinary Medicine, v. 22, n. 1-2, p. 71-87,

GREENWOD, P. L.; NORTH, R. N.; KIRKLAND, P. D. Prevalence, spread and control of caprine arthritis-encephalitis virus in dairy goat herds in New South Wales. Australian Veterinary Journal, v. 72, n. 9, p. 341- 345, 1995.

GREWAL, A. S.; GREENWOOD, P. E.; BURTON, R. W.; SMITH, J. E.; BATTY, E. M.; NORTH, R. Caprine retrovirus in New South Wales: virus isolation, clinical and histopathological findings and prevalence of antibody. Australian Veterinary Journal, v. 63, n. 8, p. 245-248, 1986.

HÄNEL, A. Ein Beitrag zur serologischen Diagnose der Caprinen Arthritis-Enzephalitis (CAE) bei Ziegen und der Maedi-Visna (MV) bei Schafen. Tierärztliche Umschau, v. 46, n. 4, p. 665-673, 1991.

HECKERT, R. A.; McNAB, W. B.; RICHARDSON, S. M.; BRISCOE, M. R. Evaluation of an Enzyme-linked Immunosorbent Assay for the detection of antibodies to Caprine Arthritis-Encephalitis Virus in goat serum. Canadian Journal of Veterinary Research, v. 56, n. 3, p. 237-241, 1992.

HEIL, G. Serological survey of the occurrence of caprine arthritis encephalitis in pedigree goat herd in Baden-Wurttenberg German Federal Republic.Tierärztliche

Umschau, v. 41, n. 8, p. 530-532, 1986.

HÖTZEL, I.; BASTOS, E. S.; RAVAZZOLO, A. P.; MOOJEN, V. Caprine arthritis-encephalitis virus: isolation and identification in Rio Grande do Sul, Brazil. Brazilian Journal of Medical and Biological Research, v. 23, n. 11, p. 1175-1179, 1993.

HOUWERS, D. J. Review of caprine arthritis encephalitis and its significance for goat keepens in the Netherlands. Tijdschrift voor Diergeneeskunde, v. 112, n. 18, p. 1047-1053, 1987.

HOUWERS, D. J.; GIELKENS, A. L. J.; SCHAAKE, J. An indirect enzyme-linked immunosorbent assay (ELISA) for the detection of antibodies to maedi-visna virus. Veterinary Microbiology, v. 7, n. 1, p. 209-219, 1982.

INSTITUTO BRASILEIRO DE GEOGRAFIA E ESTATÍSTICA - IBGE. Censo agropecuário. Disponível em: $\quad<$ http://www.ibge.gov.br/ibge/estatistica/economia/agropecuaria/ censoagro/default.shtm>. Acesso em: 22 out. 2001.

JARDIM, W. R. Criação de caprinos . 7. ed. São Paulo: Nobel, 1973. 240 p. 192

JOAG, S. V.; STEPHENS, E. B.; NARAYAN, O. Lentiviruses. In: FIELDS, B. N.; KNIPE, D. M.; HOWLEY, P. M. Fields Virology. Philadelphia: Lippincott-Raven, 1996. p. 1977-1996. 
KENNEDY-STOSKOPF, S.; NARAYAN, O.; STRANDBERG, J. D. The mammary gland as a target organ for infection with caprine arthritis-encephalitis virus. Journal of Comparative Pathology, v. 95, n. 2, p. 609-617, 1985.

KNOWLES, D. Laboratory diagnostic tests for retrovirus infections of small ruminants. The Veterinary Clinics of North America: Food Animal Practice, v. 13, n. 1, p. 1-11, 1997.

KREMERS, B.; BRIERE, R.; BATSAKIS, J. G. Reflectance densitometry of cellulose acetate protein eletrophoresis. American Journal of Medical Technology, v. 33, n. 1, p. 28-34, 1967.

KRIEG, A.; PETERHANS, E. Die Caprine Arthritis-Encephalitis in der Schweiz: epidemiologische und klinische Untersuchungen. Schweizer Archiv für Tierheilkunde, v. 132, n. 7, p. 345-352, 1990.

LEAL, M. L. R. Função hepática em bezerras sadias, da raça Holandesa, no primeiro mês de vida - Influência do fator etário. 2001. 111 f. Dissertação (Mestrado em Clínica Veterinária) Faculdade de Medicina Veterinária e Zootecnia, Universidade de São Paulo, São Paulo.

LERONDELLE, C.; FLEURY, C.; VIALARD, J. Le gland mammaire: organe cible de l'infection par le virus de l'arthrite et de l'encéphalite caprine. Annales de Recherches Veterinaires, v. 20, n. 1, p. 57-63, 1989.

LERONDELLE, C.; GREENLAND, T.; JANE, M.; MORNEX, J. F. Infection of lactating goats by mammary instillation of cell-borne caprine arthritis-encephalitis virus. Journal of Dairy Science, v. 78, n. 4, p. 850-855, 1995.

MACDIARMIND, S. C. Survey suggest low prevalence of caprine arthritis-encephalitis. Surveillance, v. 10, n. 1, p. 408, 1986.

MELO, A. C. M.; FRANKE, C. R. Soroprevalência da infecção pelo vírus da artrite-encefalite caprina (CAEV) no rebanho de caprinos leiteiros da região da Grande Fortaleza, Ceará, Brasil. Ciência Rural, v. 27, n. 1, p. 113-117, 1997.

MONICAT, F. Caprine arthritis-encephalitis in France. Veterinary Record, v. 120, n. 20, p. 478, 1987.

MOOJEN, V.; CORREA SOARES, C.; RAVAZZOLlO, A. P.; DAL PIZZOL, M.; GOMES, M. Evidência de infeção pelo lentivirus (MAEDI/VISNA - Artrite-encefalite Caprina) em caprinos no Rio Grande do Sul, Brasil. (Comunicação científica). Arquivos da Faculdade de Medicina Veterinária da Universidade Federal do Rio Grande do Sul, v. 14, n. 14, p. 77-78, 1986. 
NARAYAN, O.; ClemENTS, J. E.; STRANDBERG, J. D.; CORK, L. C.; GRIFFIN, D. E. Biological characterization of the virus causing leukoencephalitis and arthritis in goats. Journal of General Virology, v. 50, n.1, p. 69-79, 1980.

NARAYAN, O.; CORK, L. C. Caprine arthritis-encephalitis virus. In: DINTER, Z.; MOREIN, B. Virus infections of ruminants. Amsterdam, Netherlands: Elsevier Science, 1990. p. 441-452.

NARAYAN, O.; KENNEDY-STOSKOPF, S.; SHEFFER, D.; GRIFFIN, D. E.; CLEMENTS, J. E. Activation of caprine arthritis-encephalitis virus expression during maturation of monocytes to macrophages. Infection and Immunity, v. 41, n. 1, p. 67-73, 1983.

NARAYAN, O.; WOLINSKY, J. S.; CLEMENTS, J. E.; STRANDBERG, J. D.; GRIFFIN, D. E.; CORK, L. C. Slow virus replication: the role of macrophages in the persistence and expression of visna virus of sheep and goats. Journal of General Virology, v. 59, n. 2, p. 345-356, 1982.

NAZARA, S. J.; TRIGO, F. J.; SUBERBIE, E.; MADRIGAL, V. Estudio serologico de la artritisencefalitis caprina en Mexico. Tecnica Pecuaria en Mexico, n.48, p.98-101, 1985.

OFFICE INTERNATIONAL DES EPIZOOTIES. Manual of standards for diagnostic tests and vaccines. World Organisation for Animal Health. $4^{\text {th }}$ ed. 2000. Disponível em: $<$ http://www.oie.int/eng/normes/mmanual/A_00065.htm>. Acesso em: 23 out. 2001.

OLIVER, R. E.; ADAMS, D. S.; GORHAM, J. R.; JULIAN, A. F.; McNIVEN, R. A.; MUIR, J. Isolation of caprine arthritis-encephalitis virus from a goat. New Zealand Veterinary Journal, v. 30, n. 10, p. 147-149, 1982.

PALFI et al., 1986 apud BIRGEL, 2000, p. 8.

PAWLISH, R. A.; MAES, R. K. Caprine arthritis-encephalitis virus isolated from Michigan goats. American Journal Veterinary Research, v. 45, n. 9, p. 1008-1011, 1984.

PERRIN, G.; POLACK, B. L'arthrite encéphalite caprine (CAE). Bulletin de L'A cademie Vetérinaire de France, v. 60, n. 2, p. 125-136, 1987.

PERRIN, G.; POLACK, B.; MONICAT, F.; FLECHE-SABAN, C.; RUSSO, P.; VITU, C.; ASSO, J.; SAVEY, M. Maladie des gros genoux de la chévre (CAEV): connaissances actuelles. Le Point Vétérinaire, v. 20, n. 3, p. 521-523, 1988.

PÉTURSSON, G.; ANDRÉSDÓTTIR, V.; ANDRÉSSON, O.S.; GEORGSSON, G.; PÁLSSON, P. A.; RAFNAR, B.; TORSTEINSDÓTTIR, S. Lentivirus diseases of 
sheep and goats: Maedi-visna and Caprine arthritis-encephalitis. In: SPEEDY, A. W. Progress in sheep and goat research. 1. ed. Redwood Press, 1992. p. 107- 129.

PINHEIRO, R. R.; ALVES, F. S. F.; GIRÃO, E. S; MEDEIROS, L. P. A.; GIRÃO, R. N. Presença da artrite encefalite caprina a vírus (CAEV) em Teresina-Piauí. In: CONGRESSO BRASILEIRO DE MEDICINA VETERINÁRIA, 24. 1996, Goiânia. Anais... Goiânia: Sociedade Goiânia de Veterinária. p. 161.

PINHEIRO, R. R.; GOUVEIA, A. M. G.; ALVES, F. S. F. Prevalência da infecção pelo vírus da Artrite Encefalite Caprina no Estado do Ceará, Brasil. Ciência Rural, v. 31, n. 3, p. 449-454, 2001.

RAMALHO, E. J. Artrite encefalite caprina - CAE: Prevalência de anticorpos séricos em caprinos no Estado da Bahia. 2000. 109 f. Tese (Doutorado em Clínica Veterinária) - Faculdade de Medicina Veterinária e Zootecnia, Universidade de São Paulo, São Paulo, 2000.

REISCHAK, D. Lentivírus de Pequenos Ruminantes: Imunofluorescência utilizando isolados brasileiros para diagnóstico sorológico de infecção em ovinos e caprinos. 2000. 132 f. Dissertação (Mestrado em Ciências Veterinárias) - Faculdade de Veterinária, Universidade Federal do Rio Grande do Sul, Porto Alegre.

RIMSTAD, E.; EAST, N. E.; TORTEN, M.; HIGGINS, J.; DeROCK, E.; PEDERSEN, N. C. Delayed seroconversion following naturally acquired caprine arthritis-encephalitis virus infection in goats. American Journal of Veterinary Research, v. 54, n. 11, p. 1858-1862, 1993.

ROSADIO, R.; RIVERA, H. Mastitis intersticial linfoide asociada al virus de la artritis-encefalitis caprina. Revista Investigacion pecuaria, v. 6, n. 2, p. 119-123, 1993.

ROSENBERGER, G. Exame clínico dos bovinos. 2. ed. Rio de Janeiro: Guanabara Koogan, 1983. $429 \mathrm{p}$.

ROSSINI, A. J.; GARCIA, M.; ARAÚJO; W. P.; IWASAKI, M. Micoplasmose caprina. Relato de dois casos ocorridos no Estado de São Paulo. In: SEMANA DE MEDICINA VETERINÁRIA DA FACULDADE DE MEDICINA VETERINÁRIA E ZOOTECNIA DA UNIVERSIDADE DE SÃO PAULO. 4. 1996, São Paulo. Anais... p. 70.

ROWE, J. D.; EAST, N. E.; FRANTI, C. E.; THURMOND, M. C.; PEDERSEN, N. C.; THEILEN, G. $\mathrm{H}$. Risk factors associated with the incidence of seroconversion to caprine arthritis-encephalitis virus in goats on California dairies. American Journal of Veterinary Research, v. 53, n. 12, p. 2396-2403, 1991.

ROWE, J. D.; EAST, N. E.; THURMOND, M. C.; FRANTI, C. E.; PEDERSEN, N. C. Cohort study of natural transmission and two methods for control of caprine 
arthritis-encephalitis virus infection in goats on a California dairy. American Journal of Veterinary Research, v. 53, n. 12, p. 2386-2395, 1992.

RUSSO, P. Isolement d'un vírus dans une enzootie de polyarthrites chez la chèvre. Bulletin de l'Academie Veterinaire de France, v. 56, n. 1, p. 31-38, 1983.

SAMAN, E.; EYNDE; G.; LUJAN, L.; EXTRAMIANA, B.; HARKISS, G.; TOLARI, F.; GONZÀLEZ, L.; AMORENA, B.; WATT, N.; BADIOLA, J. A new sensitive serological assay for detection of lentivirus infections in small ruminants. Clinical and Diagnostic Laboratory Immunology, v. 6, n. 5, p. 734-740, 1999.

SARAIVA NETO, A. O.; CASTRO, R. S.; BIRGEL, E. H.; NASCIMENTO, S. A. Estudo soroepidemiológico da artrite-encefalite caprina em Pernambuco. Pesquisa Veterinária Brasileira, v. 15, n. 4, p. 121-124, 1995.

SCHÖPF, M. C.; SHÖNBAUER, M. Serologiche Erhebungsuntersuchung über die Verbreitung der Caprien Arthritis-enzephalitis CAE in Tirol. Wiener Tierärztliche Monatsschrift, v. 77, n. 8, p. 249$252,1990$.

SERAKIDES, R.; NUNES, V. A.; PEREIRA, M. F. Estudo clínico, anatomopatológico e imunohistoquímico de pulmões de cabras natualmente infectadas pelo vírus da artrite encefalite caprina (CAE). Arquivo Brasileiro de Medicina Veterinária e Zootecnia, v. 48, n. 4, p. 415-424, 1996.

SIMS, L. D.; HALE, C. J.; McCORMICK, B. M. Progressive intersticial pneumonia in goats. Australian Veterinary Journal, v. 60, n. 12, p. 368-371, 1983.

SMITH, M. C.; CUTLIP, R. Effects of infection with caprine arthritis-encephalitis virus on milk production in goats. Journal of American Veterinary Medicine Association, v. 193, n. 1, p. 63-67, 1988.

SMITH, M. C.; SHERMAN, D. M. Caprine arthritis encephalitis. Goat medicine. Philadelphia: Lea \& Febiger, 1994. p. 73-79.

STRAUB, O. C. Vorkommen der virusbedingten ziegen (caprinen) arthritis-enzephalitis (CAE) in der Bundesrepublik Deustschland. Tierärztliche Umschau, v. 38, n. 12, p. 896-902, 1983.

STRUFALDI, B. Prática de bioquímica clínica. São Paulo: Faculdade de Ciências Farmacêuticas da Universidade de São Paulo, 1987. 399 p.

STÜNZI, H.; BUCHI, H. F.; LE ROY, H. L.; LEEMANN, W. Endemische Arthritis chronica bei Ziegen. Schweizer Archiv fur Tierärtzkunden, v. 106, n. 12, p. 778-788, 1964.

SUNDQUIST, B.; JÖNSSON, L.; JACOBSSON, S. O.; HAMMARBERG, K. E. Visna virus meningoencephalomyelitis in goats. Acta Veterinaria Scandinavia, v. 22, n. 3-4, p. 315-330, 1981. 
SURMAN, P. G.; DANIELS, E.; DIXON, B. R. Caprine arthritis-encephalitis virus infection of goats in South Australia. Australian Veterinary Journal, v. 64, n. 2, p. 266-271, 1987.

SWENSON, M. J. Propriedades fisiológicas e componentes químicos e celulares do sangue. In: SWENSON, M. J.; REECE, W. O. (Ed.) Dukes Fisiologia dos animais domésticos. Rio de Janeiro: Guanabara Koogan, 1996. p. 19-43.

SZASZ, G. A kinetic photometric method for serum gama glutamil transpeptidase. Clinical Chemistry, v. 15, n. 2, p. 124-135, 1969.

TEST, M. D.; CONCHA-BERMEJILlo, A.; ESPINOSA, L. E. L.; RUBIO, E. L.; SETIÉN, A. A. Isolation of caprine arthritis encephalitis virus from goats in México. Canadian Journal of Veterinary Research, v. 63, n. 3, p. 212-215, 1999.

THOMPSON, J. C; PAULI, J. V. Colostral transfer of gamma glutamyl transpeptidase in calves. New Zealand Veterinary Journal, v. 29, n. 12, p. 223-226, 1981.

TRAVASSOS, C. E.; BENOÎT, C.; VALAS, S.; SILVA, A. G.; PERRIN, G. Caprine arthritisencephalitis virus in semen of naturally infected bucks. Small Ruminant Research, v. 32, n. 1, p. 101-106, 1999.

VIEIRA, M. I. Criação de cabras: técnica prática lucrativa. 2. ed. São Paulo: Nobel, 1986. 215 p.

VON MOCKENHAUPT, C.; BAUER, K. Untersuchungen zur Caprinen Arthritis-Enzephalitis in Bayern und der einsefluss seuchen-hygienischer massnahmen auf den Verlauf dieser Krankheit. Tierärztliche Umschau, v. 42, n. 12, p. 966-970, 1987.

WOODWARD; J. C.; GASKIN, C.; POULOS, P. W.; MACKAY, R. J.; BURRIDGE, M. J. Caprine arthritis-encephalitis: clinicopathologic study. American Journal of Veterinary Research, v. 43, n. 12, p. 2085-2096, 1982.

ZANONI, R. "Lentiviruses: A Brief Review”. Etudes et Syntheses de l'TEMVT, n. 42, p. 1-8, 1993.

ZANONI, R.; KRIEG, A.; PETERRHANS, E. Detection of antibodies to caprine arthritis-encephalitis virus by protein $G$ enzyme-linked immunosorbent assay and immunoblotting. Journal of Clinical Microbiology, v. 27, n.3, p. 580-582, 1989.

ZINK, M. C.; YAGER, J. A.; MYERS, J. D. Pathogenesis of caprine arthritis encephalitis virus: cellular localization of viral transcripts in tissues of infected goats. American Journal of Pathology, v. 136, n. 4, p. 843-849, 1990. 